\title{
Geology of Uranium and
}

Associated Ore Deposits

Central Part of the

\section{Front Range Mineral Belt Colorado}

By P. K. SIMS and others

GEOLOGICAL SURVEY PROFESSIONAL PAPER 371

Prepared on behalf of the U.S.

Atomic Energy Commission

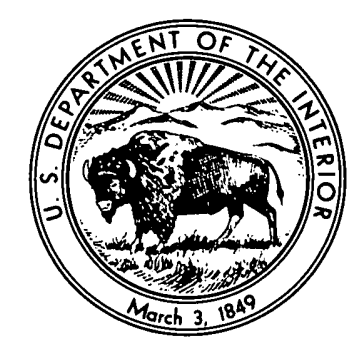

UNITED STATES GOVERNMENT PRINTING OFFICE, WASHINGTON : 1963 
UNITED STATES DEPARTMENT OF THE INTERIOR

\section{STEWART L. UDALL, Secretary}

\section{GEOLOGICAL SURVEY}

Thomas. B. Nolan, Director

The U.S. Geological Survey Library catalog card for this publication appears after page 119

For sale by the Superintendent of Documents, U.S. Government Printing Office Washington, D.C., 20402 


\section{PREFACE}

This report is based on fieldwork in the central part of the Front Range mineral belt between 1951 and 1956 by geologists of the U.S. Geological Survey on behalf of the U.S. Atomic Energy Commission. The work was curried on by nine authors working in different parts of the region. Therefore, although the senior author is responsible for the sections of the report that are not ascribed to individual members, the entire report embodies the efforts of the group, which consisted of F. C. Armstrong, A. A. Drake, Jr., J. E. Harrison, C. C. Hawley, R. H. Moench, F. B. Moore, P. K. Sims, E. W. Tooker, and J. D. Wells. 


\section{CONTENTS}

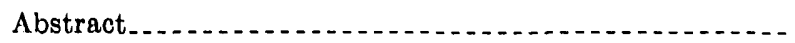

Introduction . . .

Purpose and scope of report.

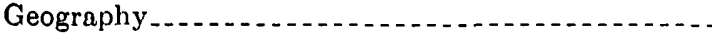

Previous geologic studies..........

Present investigation

Acknowledgments.

History of uranium mining and production.........

Geologic setting

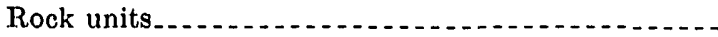

Precambrian rocks. . . . . . .

Tertiary intrusive rocks. . . . . . . .

Radioactivity of country rocks.

Precambrian rocks. .

Thorium- and rare-earth-bearing gneiss and

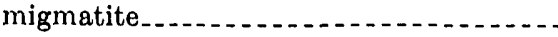

Uranium-bearing pegmatite.............

Biotite-muscovite granite . . . . . . . . . . . .

Tertiary intrusive rocks......................

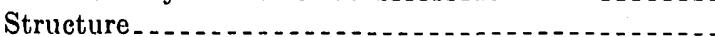

Structure of Precambrian rocks...........

Form of Tertiary intrusive rocks........

Joints.

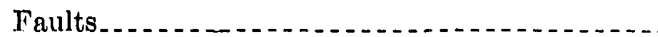

Classification and description............ Faults of Precambrian(?) age ......... Faults of Laramide age...........

Fault pattern.

Age and origin of faults...........

Summary of geologic history

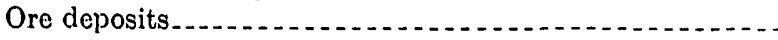

Structure and general character......................

Mineralogy . . . . . . . . . . . . . . .

Classification of veins . . . .

Hypogene mineral zoning . . . . . .

Regional zoning

Longitudinal zoning of veins..............

Depth zoning ..............................

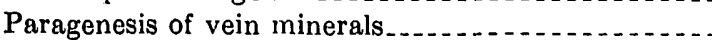

Wallrock alteration, by E. W. Tooker . . . . . . . . .

Genesis of sulfide veins

Uranium deposits.... . . . . . . . . . . . . . . . . . .

Abundance and distribution of uranium in veins . . .

Mineralogy . . . .

Pitchblende.

Texture. . . . . . . . . . . . . . . .

Variation in physical appearance........

Variation in state of oxidation ...........

Chemical composition of pitchblende.....

Minor elements in pitchblende..........

Torbernite and metatorbernite

Autunite and meta-autunite

Kasolite. . . .

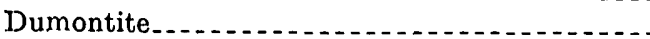

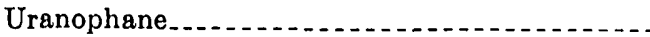

Bayleyite.

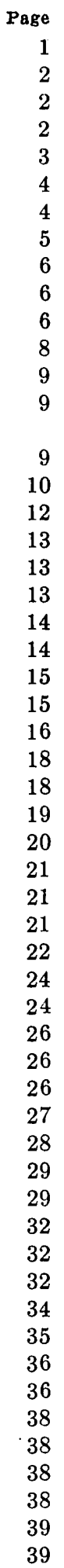

Uranium deposits-Continued

Mineralogy-Continued

Zippeite and betazippeite.............. 39

Schroeckingerite .......... 39

Thucholite(?) $\ldots \ldots \ldots$

Johannite

Paragenetic relations of pitchblende to the common

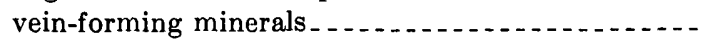

General character and structure ..............

Relation of deposits to fault sets

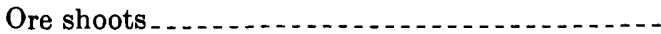

Grade of primary deposits . . .

Mineralogical and chemical character of wallrocks.-.

Localization of ore

Relation of primary ores to depth...............

Relation of uranium deposits to sulfide mineral zoning-

Supergene alteration

Relation of alteration products to water table and primary ore

Occurrence of secondary uranium minerals ..... Grade of secondary deposits...............

Chemical considerations. ...................

Origin of uranium deposits.

Source of uranium

Chemical environment of deposition

Age

Future production

Mine descriptions

Central City district. . . .

Quartz Hill-upper Russell Gulch area......... $\quad 55$

Flack vein.

West Flack mine ......... 56

Mercer County mine... 58

German and Belcher mines........... 59

Iron mine, by A. A. Drake, Jr........ 61

Jefferson-Calhoun vein . . . . . .

Kirk mine . . . . . . . . . . 63

Old Town mine, by A. A. Drake, Jr.... 65

Springdale (Gold Rock) mine, by A. A.

Drake, Jr........

Telegraph mine

Wood vein

Eureka Gulch area..........

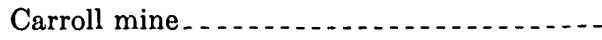

Claire Marie mine . . . .................

St. Anthony and R.H.D. mines.........

Two Sisters mine ......................

Justice Hill and adjacent areas . . . . . . . . . . .

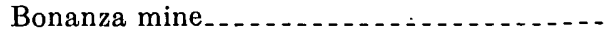

Cherokee vein .............................

Pewabic tunnel, by A. A. Drake, Jr......

Silver Hill area . . . . . . . . . . . . . . . . . .

Blackhawk Lode No. 2 claim ........... Powhatan tunnel, by A. E. Dearth........

39

41 43 44 59

\section{age} (

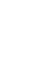

41 48 48 49 50 51. 53

5

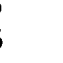

8

.


Mine descriptions-Continued

Lawson-Dumont-Fall River district, by C. C. Hawley and F. B. Moore

Fall River area.................................

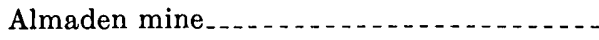

Golconda tunnel

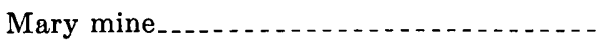

Lawson area $\ldots$

Bellevue-Hudson mine . . . . . . . . . . . Jo Reynolds mine

Robineau (Peabody) prospect. . . . . . .

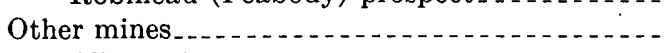

Albro mine........

Golden Calf mine.........................

Idaho Springs district, by R. H. Moench. . . . . .

Alma Lincoln mine

Diamond Joe tunnel, by A. A. Drake, Jr....

Jennie Lind No. 1 tunnel. .......

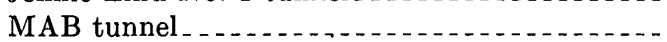

New Bedford tunnel. . . .

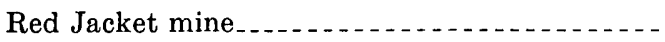

Shafter mine..........

Stanley mine..........

Star mine

Sunnyside mine, by J. E. Harrison and R. H.

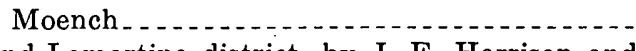

Freeland-Lamartine district, by J. E. Harrison and

J. D. Wells .

Ariadne mine............

Belle Creole tunnel.

Brazil mine.
Page Mine descriptions-Continued

Freeland-Lamartine district, etc-Continued

Crazy Girl mine

Diamond Mountain mine...............

Harrisburg mine.....

Lamartine mine . . . . . .

Little Johnie group $\ldots$

Lone Tree mine . . .

Miller mine ..............

Poor Man mine.....

Chicago Creek area, by J. E. Harrison and J. D.

Wells

Alpine mine...

Blackwood mine

Bruce mine . .

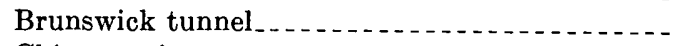

Chicago mine. . . . .

Dixie mine..........

Eclipse mine . . .

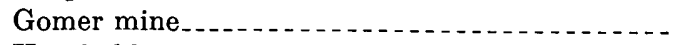

Humboldt mine

Katie Emmett mine...

Muscovite tunnel. 112

Orinoco tunnel.

Silver Link tunnel _.

Tyone mine........ 113

Wallace tunnel........ 114

Literature cited

Index . .
111

111

111

111

111

111

111

112

112

112

112 2

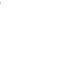

\section{ILLUSTRATIONS}

[Plates are in pocket]

Plate 1. Map of the central part of the Front Range mineral belt, Colorado, showing metalliferous veins and Tertiary igneous rocks.

2. Traces of faults and veins, central part of the Front Range mineral belt.

3. Map showing abnormally radioactive localities in the central part of the Front Range mineral belt.

4. Geologic map and section of part of Quartz Hill, Central City district.

5. Geologic maps and section of the German mine.

6. Longitudinal projection in the plane of the vein, Kirk mine.

7. Composite geologic map and section of the Carroll mine.

8. Geologic map of part of Justice Hill.

9. Geologic map of the Martha $\mathbf{E}$ mine and assay map of the west wall of winze, Chicago Creek area.

Figure 1. Map of the Front Range, Colorado

2. Map showing the mining districts in the central part of the Front Range mineral belt that were mapped during this investigation.

3. Generalized geologic map of the Precambrian rocks, central part of the Front Range mineral belt

4. Diagram showing probable sequence of intrusion of the Tertiary igneous rocks

5. Outcrop map of the Highlander and adjacent mining claims, Idaho Springs district

6. Map showing principal Precambrian(?) faults within and adjacent to the central part of the Front Range mineral belt.........

7. Diagram showing the approximate quantities of the principal metallic vein minerals in pyrice and galenasphalerite veins.....

8. Map showing zonal arrangement of the ores in the central part of the Front Range mineral belt

9. Drawing of polished surface of pitchblende ore from the J. P. Whitney mine 
Figures 10-22. Photomicrographs of pitchblende.

10. Flack mine, spheroidal form

11. J. P. Whitney mine, colloform ore

12. Jo Reynolds mine, colloform ore

13. Jo Reynolds mine, vein ore

14. Carroll mine, vein ore

15. Flack mine, pellet texture

16. Wood vein, East Calhoun mine, massive ore

17. Carroll mine, altered ore

18. Carroll mine, more advanced alteration

19. Carroll mine, stringers of ore

20. Wood vein, East Calhoun mine, brecciated, recemented ore

21. Kirk mine, relation of pitchblende to quartz and pyrite

22. Almaden mine, pitchblende enclosing other minerals

23. Vertical longitudinal projection of the Carroll mine

24. Geologic map showing pitchblende-bearing ore, Carroll mine

25. Assay map of pitchblende-bearing lens, Wood vein, East Calhoun mine

26. Assay section of part of stope in the Carroll mine.

27. Vertical longitudinal projection of German and Belcher mines

28. Diagram showing relations of secondary and primary uranium minerals in weathered galena-sphalerite veins

29. Sections of the West Flack mine, Central City district.

30. Sections of the Mercer County mine

31. Geologic map of the 115 level, Mercer County mine

32. Geologic map of part of the 300 level, Iron mine

33. Geologic maps showing pitchblende occurrences in Old Town mine

34. Vertical longitudinal projection of the Springdale mine

35. Geologic section of stope face, Denbigh vein, Springdale mine

36. Vertical longitudinal projection of the Wood mine

37. Geologic map of the north slope of Nigger Hill

38. Assay section, Carroll mine.

39. Geologic map and section of the Claire Marie mine

40. Geologic maps and section, St. Anthony and R.H.D. mines -

41. Geologic maps of the 105 and 179 levels, Two Sisters mine.

42. Vertical longitudinal projection showing workings on Claire Marie vein, Nigger Hill

43. Vertical longitudinal projection of the Two Sisters vein, Two Sisters mine

44. Vertical longitudinal projection of the Bonanza mine, Central City district.

45. Geologic maps of the adit and 100 levèls, Bonanza mine

46. Shaft section, showing radioactivity and analysis of pitchblende-bearing ore, Bonanza mine

47. Vertical longitudinal projection of the Cherokee vein

48. Geologic map of the 108 level, Cherokee mine

49. Section of the upper part of the Cherokee shaft, showing occurrence of pitchblende

50. Geologic map of the Pewabic tunnel

51. Sketch map and section of shaft workings, Blackhawk Lode No. 2 claim

52. Geologic map of the adit level, Blackhawk Lode No. 2 claim

53. Geologic map of the Powhatan tunnel

54. Composite map showing the relation of mines containing pitchblende deposits, Fall River area

55. Geologic map of part of the Golconda tunnel.

56. Geologic section of vein 4 in the winze, Golconda tunnel

57. Geologic map of part of the Mary mine

58. Vertical longitudinal projection showing workings on the Jo Reynolds No. 2 vein

59. Geologic map of the Elida tunnel level, Jo Reynolds mine, Lawson-Dumont-Fall River district. - - .-...-

60. Geologic map of the Golden Calf mine.

61. Geologic map of the New Bedford mine, Idaho Springs district.

62. Geologic map of the Star mine.

63. Geologic map of the Sunnyside mine 


\section{TABLES}

TABLE 1. Uranium production from the Central City district and adjoining areas, 1871-1955

2. Principal Precambrian rock units in the central part of the Front Range mineral belt................

3. Semiquantitative spectrographic, radiometric, and chemical analyses of thorium- and rare-earth-bearing biotite gneiss and migmatite, Central City district . . . . .

4. Analyses of uraninite-bearing pegmatites, Idaho Springs district

5. Analyses of uraninite-bearing pegmatite from the Highlander claim, Idaho Springs district . . . . . . . . . .

6. Average equivalent uranium and uranium content of the Tertiary intrusive rocks, central part of the Front Range mineral belt

7. Principal joint sets in mining districts of the central part of the Front Range mineral belt

8. Primary and secondary vein minerals, exclusive of uranium minerals

9. Uranium analyses from localities with high abnormal radioactivity

10. Uranium analyses from localities with moderate abnormal radioactivity

11. Uranium analyses from localities with low abnormal radioactivity

12. X-ray powder data and uranium oxidation state of pitchblende from the central part of the Front Range mineral belt.

13. Semiquantitative spectrographic analyses of pitchblende concentrates, Central City and Lawson-DumontFall River districts

14. Wallrocks of uranium deposits

15. Chemical analyses and modes of wallrocks for uranium-bearing veins

16. Relation of primary uranium deposits to depth .

17. Analyses from the Mercer County mine

18. Selected assays from the German mine

19. Uranium analyses from the German mine.

20. Uranium, gold, silver, lead and zinc analyses from the German mine

21. Uranium analyses from the Old Town mine

22. Production from the Carroll mine, 1954-55

23. Chemical analyses, fire assays, and spectrographic analyses of vein material from the Carroll mine ........

24. Chemical analyses and fire assays of vein material from shaft and stopes of the Carroll mine

25. Uranium content of samples from the Bonanza mine.

26. Equivalent uranium content of samples from the Pewabic tunnel

27. Analyses of uranium-bearing vein from shaft on the Blackhawk Lode No. 2 claim

28. Analyses of zippeite-bearing material from the Diamond Joe tunnel. 


\title{
GEOLOGY OF URANIUM AND ASSOCIATED ORE DEPOSITS, GENTRAL PART OF THE FRONT RANGE MINERAL BELT, COLORADO
}

\author{
By P. K. Sims and others
}

\begin{abstract}
The Central City district and adjoining mining areas in the central part of the Front Range mineral belt have supplied small quantities of uranium ore intermittently since the discovery of pitchblende at Central City in 1871. During the early years of development the uranium production from the region was of national importance, and until 1951 the region was this country's principal domestic source of pitchblende. In recent years, however, the production has been insignificant although the search for uranium has been greater than at any previous time. The pitchblencle occurs as a local minor constituent of gold- and silver-bearing base-metal sulfide veins, chiefly valuable for their gold content, which have yielded ores valued at nbout $\$ 200$ million.

The mining districts of the central part of the Front Range minernl belt are in a terrane of complexly folded Precambrian crystulline rocks, which constitute the core of the Front Range, and are near instrusive centers of porphyritic igneous rocks of enrly Tertiary age. The Precambrian rocks are an interlayered and generally conformable sequence of metasedimentary rocks, migmatites, and intrusive igneous rocks, some of which are metamorphosed. The Tertiary intrusive rocks include a wide variety of calc-alkalic to alkalic rocks ranging in composition from granodiorite porphyry to alaskite porphyry and quartz bostonite porphyry. In general, the older Tertiary intrusive rocks occur as small irregular plutons, whereas the younger rocks form long nurrow dikes.

Although most of the Precambrian rocks have a low natural radionctivity, a local phase of metasedimentary blotite gneiss, two varieties of pegmatite, and biotite-muscovite granite are abnormally radionctive. Except for one variety of pegmatite that contains uraninite, the radioactivity results largely from thorium and its disintegration products in the minerals monazite and xenotime.

The Tertiary igneous sequence of the region is one of the most radionctive groups of intrusive rocks in the world. The radionctivity of quartz bostonite porphyry-the most radioactive rock of the sequence-is 15 to 25 times as great as the average granitic rock, and results from both thorium and uranium, which according to George Phair of the Geological Survey, occur largely in primary zircon.

The tectonic framework of the region developed in Precambriun time. The rocks were deformed by two periods of folding and subsequently faulted. Complex major folds which define the gross distribution of the rock units were formed by an early plastic deformation that took place at great depth in the crust. This was accompanied by the development of migmatites and the emplacement of intrusive igneous rocks. Minor folds, oriented differently than the older major folds, and cataclastic
\end{abstract}

products were formed by a younger deformation of local extent. This deformation was intense in a 2-mile-wide zone that trends northeast along the southeast margin of the mineral belt. Major faults that trend northwest or north-northeast probably developed initially in the Precambrian, subsequent to the younger folding. These faults locally contain siliceous breccia. "reefs," and are cut by the early Tertiary porphyritic igneous rocks. Characteristically they have a dominantly horizontal relative motion and apparent displacements of several teñs or hundreds of feet.

During the Laramide orogeny three sets of faults were formed and movements were recorded on the older fracture sets. Faults that trend northeast, east-northeast, and east developed after the emplacement of all the early Tertiary intrusive rocks except the youngest, biotite-quartz latite porphyry. These faults differ from the older faults in being discontinuous and having small displacements; possibly they are nearly restricted to the mineral belt.

The ore deposits of the region are gold-, silver-, copper-, lead-, zinc-, and uranium-bearing veins that formed as hydrothermal fissure fillings in the faults. The structure, mineralogy, and texture of the veins are similar to those described by Lindgren as mesothermal. The veins range from single, well-defined flled fissures to complex, branching lodes consisting of subparallel fractures, loops, and horsetailing fractures; in general they are 1 to 2 feet wide, with the lower figure being most common. The principal ore minerals are sulfides and sulfosalts of iron, copper, lead, and zinc; pitchblende is a local constituent. Quartz is the dominant gangue mineral, but rhombohedral carbonates, fluorite, and barite are present in some veins.

The veins in the region differ in quantitative mineralogy. They can be classified into two main types, one characterized by dominant pyrite and the other by dominant galena and sphalerite. The distribution of veins of the two contrasting types indicates a regional concentric zonal arrangement of the ores around a major center of mineralization. A large irregular core area (central zone) of pyrite veins, a few containing moderate amounts of copper minerals, is surrounded by a broad outer area (peripheral zone) of galena-sphalerite veins; an.intermediate zone consists of transitional veins of the pyrite type that contain galena and sphalerite as well as copper minerals.

Uranium occurs locally in veins of different mineralogic types throughout much of the region, but is abundant in only a few veins. Of 141 localities that contain concentrations of uranium, 62 mines, including 16 that have produced uranium ore, contain selected material that assays 0.10 percent uranium or more. The remainder of the localities probably do not contain material of ore grade. Although uranium-bearing veins are widely scattered, a large proportion of the occurrences and most of the 
minable deposits are in an area of less than 1 mile square in the Central City district.

Pitchblende, a black oxide of uranium, is the primary uranium mineral in the veins. Oxidation of the pitchblende has yielded a limited variety of hexavalent uranium minerals, which are hydrous uranium phosphates, silicates, sulfates, and carbonates. The most abundant secondary minerals are torbernite, autunite, and kasolite.

The pitchblende ranges from hard black dense material with a pitchy luster to soft porous sooty material with a dull luster; all gradations exist between these extreme types. The hard pitchblende appears massive, but characteristically has a colloform texture and occurs in spheroidal forms. The sooty pitchblende is loosely aggregated. The change from a hard dense mineral to a soft sooty material is the result of oxidation and is accompanied by a decrease in the unit-cell dimension of pitchblende and a loss of definition of $\mathbf{X}$-ray diffraction powder paitterns.

The pitchblende contains a distinctive suite of minor elements which probably occur in the mineral structure. Spectrographic analyses indicate that pitchblende from the Central City district and the Lawson area is rich in zirconium, and probably in molybdenum and tungsten; all pitchblende concentrates contain yttrium, and many also contain other rare-earth elements. I:'itchblende concentrates from Fall River are nearly devoid of zirconium but contain substantial nickel and some cobalt. The nickel and cobalt occur in inclusions of foreign minerals in the pitchblende.

The pitchblende was deposited early in the sequence of vein filling, before deposition of the base-metal sulfides and sulfosalts. In the Central City district pitchblende was deposited cluring the first of three distinct stages of mineralization and preceded a pyrite stage and a base-metal stage of mineralization; at Fall River it seems to have been an early local variant of the pyrite stage of mineralization.

The pitchblende occurs locally in all fracture sets as small ienses, pods, or stringers, or rarely as larger ore shoots. The margins of the ore bodies are sharp, and commonly the vein material elsewhere is nearly devoid of uranium. Most ore bodies contain only a few tens to a few hundred pounds of ore, but some of the larger shoots contain as much as 50 tons of ore. The bodies are high in grade but narrow for mining; accordingly the grade of the shipping ore depends on the care taken in mining and sonting.

As the pitchblende was deposited as fillings of open spaces, it was localized largely by structural features that produced openings along the fissures; other important factors were proximity of the openings to the source of the ore-forming fluids and, perhaps locally, the presence of mafic wallrocks along the vein fissures.

In contrast to the gold- and silver-bearing sulfide ores, the pitchblende deposits do not extend over long vertical distances and they rarely can be profitably mined over a vertical range of more than 500 feet.

The upper parts of pitchblende-bearing veins have been altered by surficial waters and atmospheric gases. Uranium was leached from pyrite veins, but an assemblage of hexavalent secondary uranium minerals was formed by the oxidization and solution of uranium in the primary pitchblende from galenasphalerite veins. In galena-sphalerite veins the secondary uranium minerals occur with limonite in the original vein and as disseminations and fracture coatings in wallrock adjacent to the original vein. Sooty pitchblende occurs at the interface between the unoxidized and the oxidized parts of veins. At most localities secondary uranium minerals do not extend below a depth of 150 feet.

Because of the close spatial and temporal association of the ore deposits and Tertiary igneous rocks and substantiating mineralogical and chemical data, the writers infer that the uranium as well as the associated sulfide ore deposits were derived from the magmas that yielded the Tertiary igneous rocks. Uranium generally was a sparse constituent in the ore-forming fluids, but in certain environments, as at Central City, substantial quantities probably were derived from local shallow crystallizing quartz bostonite porphyry dikes. These fluids mingled with the ore-forming fluids from the main deep-seated source to yield deposits of economic value. These deposits generally were formed near the separate dike sources and manv are within 500 feet of a presumed sour ce.

The discovery of uranium-bearing ore bodies that are larger than those previously mined is doubtful; accordingly, future production of uranium from this region will probably come from scattered small pods and ore shoots distributed through the uranium-bearing veins. These bodies can be recovered most economically during the mining of precious- and base-metal ores.

\section{INTRODUCTION}

\section{PURPOSE AND SCOPE OF THE REPORT}

The Central City district and adjoining mining areas in the central part of the Front Range mineral belt were selected after World War II for study by the U.S. Geological Survey, on behalf of the U.S. Atomic Energy Commission. At that time the area was this country's principal domestic source of high-grade pitchblende, a black oxide of uranium, and in view of the current demand for uranium, it was believed that a detailed geologic survey would be of value as a part of the evaluation of the uranium resources of the United States. As the uranium occurs in metalliferous fissure veins, the survey was extended to include a study of the precious metals and base metals associated with the uranium.

This report presents a detailed discussion of the geology of the uranium deposits and includes descriptions and maps of most of the mines known to contain uranium deposits. The country rock and the ore minerals associated with the uranium deposits are described also to provide the geologic setting of the deposits.

\section{GEOGRAPHY}

The region of this investigation embraces an area of about 50 square miles in.north-central Clear Creek and south-central Gilpin counties, in the central part of the Front Range (fig. 1). It includes the Central City, Idaho Springs, Lawson-Dumont-Fall River, FreelandLamartine, and Chicago Creek mining districts, which constitute integral parts of the Front Range mineral belt. The region is about 30 miles west of Denver and about 15 miles west of Golden. The principal towns in the area-Idaho Springs, Central City, and Black Hawk-formerly had several thousand inhabitants, but 


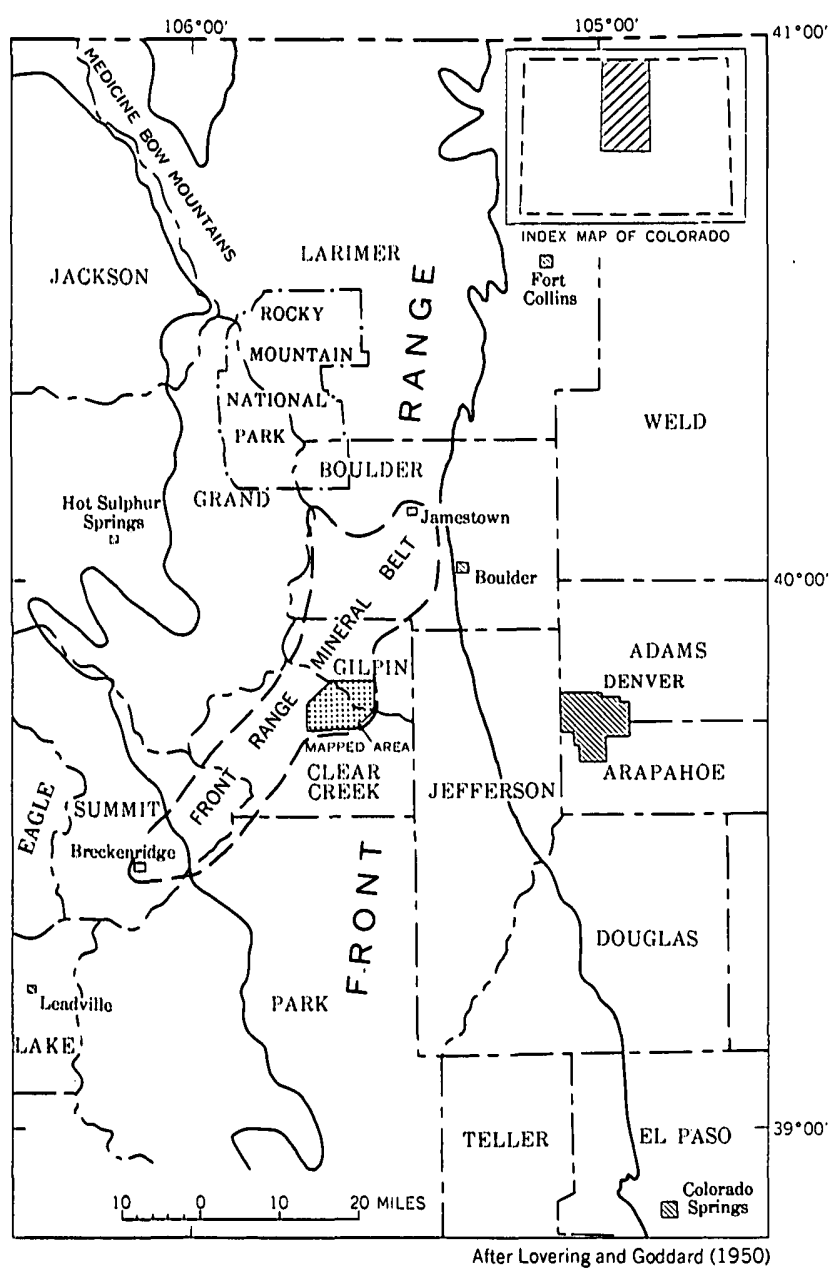

Froura 1.-Map of the Front Range, Colorndo, showing location of area covered by this report.

in 1950 Idaho Springs, the largest community, had a population of only 1,769. The region has many good automobile roads and a network of mine roads that are accessible to 4 -wheel drive vehicles. The principal highway-U.S. Highway 6 and 40-traverses the area from east to west, passing through Idaho Springs, Dumont, and Lawson. Black Hawk and Central City can be reached by State Highways 119 and 279. The narrowgage railroads that formerly served the mining districts of this area have all been abandoned; the nearest railheads are at Rollinsville, 12 miles north of Black Hawk, and at Golden, 15 miles to the east.

The region is on the east flank of the Front Range which is characterized by a gentle slope to the east and by many much-dissected benches. Altitudes range from about 11,500 feet in the southwest part of the region to 7,500 feet at Idaho Springs, in the valley of Clear Creek, the principal stream in the area which drains into the South Platte River. The local relief is as much as 1,000 feet adjacent to Clear Creek and its major tributaries but is moderate in other parts of the region.

\section{PREVIOUS GEOLOGIC STUDIES}

Many reports on the mining districts in south Gilpin and north Clear Creek counties have been published and many more, prepared by geologists and mining engineers for private companies or individuals, are not available to the public. Reports on most of the larger mines in the region have been prepared by reputable mining engineers; some of these were seen by the writers, but many others were not available. The principal published reports were prepared by the Geological Survey.

In the early 1900's the Georgetown quadrangle, which includes the southern part of the area covered by this report, was mapped by Spurr and others (1908), and the results were published as Geological Survey Professional Paper 63. A few years later, Bastin and Hill (1917) mapped the Central City and Idaho Springs mining districts and published their results as Geological Survey Professional Paper 94. During this period, and before, several geologists studied the pitchblendebearing ores in the Central City district; the principal reports concerning these ores are those by Pearce (1898), Rickard (1913), Moore and Kithil (1913), Alsdorf (1916), and Bastin (1915; 1916).

In 1950 , following several years of fieldwork in the Front Range by Lovering and Goddard, Geological Survey Professional Paper 223 was published. This report summarizes the geology of the mining districts and currently (1959) is the most authoritative source of information on the ore deposits of the Front Range.

The Geological Survey's uranium investigations in the Front Range began in 1944. The work at first was on behalf of the Manhattan Engineer district and later on behalf of the Division of Raw Materials of the U.S. Atomic Energy Commission. From 1944 to 1951 this work consisted principally of either reconnaissance of large areas or of detailed studies in mining districts that were known to contain some uranium. A reconnaissance of a large part of the Front Range was made using car-borne radioactivity detection equipment, portable scintillation counters, and portable radioactivity meters with a Geiger tube. Although these investigations were concentrated in the central part of the Front Range they also covered other parts of the range and resulted in the discovery of radioactivity over a wide area. A brief summary of this work was published in Geological Survey Circular 215 (King and others, 1953). The results of most of this work, however, were not published because of the nature of the investigations and security requirements. Detailed investigations in the mining districts were largely carried on in the central part of the Front Range mineral belt, particularly in the Quartz Hill area of the Central City district. 
A preliminary report on the pitchblende deposits in the Wood and Calhoun mines on Quartz Hill was published in 1952 (Moore and Butler, 1952). In 1951, intensive studies were made in the Quartz Hill and Justice Hill areas of the Central City district by F. C. Armstrong and in the Lawson area by B. F. Leonard and J. E. Harrison. The results of Armstrong's studies were not published, but they are partly incorporated into this report. A report on the Jo Reynolds mine in the Lawson area was published previously (Harrison and Leonard, 1952). As a result of investigations in 1951, Leonard (1952) proposed that uranium in the Front Range was related to hypogene mineral zoning. From 1949 to 1954, George Phair of the Geological Survey made geochemical investigations of uranium in the Front Range. Although his work primarily was concerned with the relation of the uranium to Tertiary porphyritic intrusive rocks (Phair, 1952), it also resulted in an important report on the leaching of pitchblende (Phair and Levine, 1953).

\section{PRESENT INVESTIGATION}

A comprehensive geologic study of the central part of the Front Range mineral belt was started in 1952 and continued through the following two field seasons; in 1955 and 1956 Sims spent a few weeks in the field. During the survey detailed studies were made of each of the five mining districts in the region (fig. 2). The surface geology in each district was mapped on a special topographic base map prepared by the Topographic Division of the Geological Survey (scale: 1:6,000), and all the accessible underground openings were mapped on scales of $1: 240$ to $1: 1,200$.

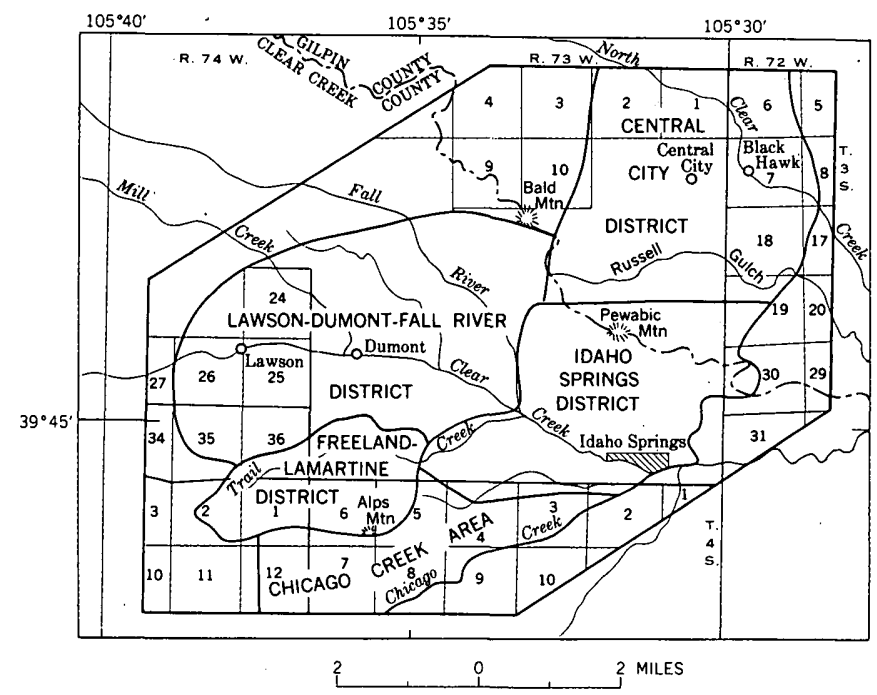

Figure 2.-Map showing the mining districts in the central part of the Front Range mineral belt that were mapped during this investi-
gation.
All mine dumps and accessible mine openings were examined for radioactivity. Two special studies were carried on during the investigation: the wallrock alteration was studied by $\mathrm{E}$. W. Tooker, and the petrology of the Tertiary igneous-rock sequence was investigated by J. D. Wells (1960).

This report describes the uranium deposits in the districts that constitute the central part of the Front Range mineral belt. Although it was compiled and largely written by the senior author, this report is based on data obtained during the study of the individual mining districts in the region; accordingly it embodies the efforts of the group, which consisted principally of P. K. Sims, F. C. Armstrong, A. A. Drake, Jr., J. E. Harrison, C. C. Hawley, R. H. Moench, F. B. Moore, E. W. Tooker, and J. D. Wells. Other members of the Geological Survey, particularly Peter Buseck, R. H. Campbell, A. E. Dearth, A. R. Krueger, J. R. McDonald, F. W. Osterwald, and Max Schafer, assisted at different times.

During the project reports were prepared on the geology and ore deposits of each of the mining districts in the region-Central City, Idaho Springs, LawsonDumont-Fall River, Freeland-Lamartine, and Chicago Creek. Reports that describe the Freeland-Lamartine district (Harrison and Wells, 1956), the Chicago Creek area (Harrison and Wells, 1959), part of the Central City district (Sims, Osterwald, and Tooker, 1955), and the ore deposits of the Wood and East Calhoun mines (Drake, 1957) have been published. Other published reports include studies of the wallrock alteration of the veins (Tooker, 1956), the relation between fracturing and hypogene mineral zoning in the FreelandLamartine district (Harrison, 1955), a reconnaissance for radioactivity in north-central Clear Creek County (Wells and Harrison, 1954), and the petrography of the Tertiary igneous rocks (Wells, 1960). Previous work also includes a summary report (Sims and Tooker, 1956) on the uranium deposits of the region, prepared for the United Nations International Conference on Peaceful Uses of Atomic Energy, and a report (Sims, 1956a) giving details of the paragenesis and structure of the pitchblende-bearing veins at Central City.

\section{ACRNOWLEDGMENTS}

The mining people throughout the region cooperated fully in every way and many individuals provided pertinent information on the history and geology of inaccessible mines. Particularly the writers wish to acknowledge the contributions of Henry deLinde, C. L. Harrington, R. R. Hinckley, Claude McKay, Van McKay, and W. C. Russell, Jr. Personnel of the U.S. Atomic Energy Commission provided many data used 
in this report. Several hundred polished sections, thin sections, and spectrographic, X-ray, and chemical analyses were made in the Denver laboratory of the Geological Survey. Individuals responsible for analyses are mentioned at the appropriate places in the text. The photomicrographs included in this report were made by Wendell Walker of the Geological Survey. Most of the data on the production of gold, silver, copper, lead, and zinc were obtained from the U.S. Bureau of Mines and are published by permission.

\section{HISTORY OF URANIUM MINING AND PRODUCTION}

The uranium production from mines in south Gilpin and north Clear. Creek Counties is insignificant when the total is compared with that from the large uraniumproducing districts in the Colorado Plateau, but prior to World War II, when uranium was used principally as a source of radium, the producing mines in the region provided a substantial quantity of the high-grade pitchblende ores used in this industry. Most of this ore was shipped to France. Some was sold in this country for purposes other than as a source of radium-as specimens, for experimental purposes, or to industrial consumers. Until 1951, when the Marysvale district, Utah, began large-scale shipments of pitchblende, the Central City district held first place in pitchblende production in the United States. To the end of 1955 a total of $123,510.8$ pounds of $\mathrm{U}_{3} \mathrm{O}_{8}$ was mined in the Central City region (table 1). All the production came from the Central City district, aside from 16,000 pounds of 72-percent $\mathrm{U}_{3} \mathrm{O}_{8}$ ore, reportedly shipped from the Jo Reynolds mine south of Iawson, and 2,920 pounds that contained 0.14 percent uranium, shipped from the Martha I mine in the Chicago Creek area.

Most of the pitchblende was mined by reusing, a method of stoping wherein the wallrock on one side of the vein is removed before the ore is broken. This method is employed on narrow veins and yields cleaner ore than when wallrock and ore are broken together. Most of the ore was hand sorted. In recent years some pitchblende from mines in the Central City district has been recovered on a Wilfley table by gravity separation. An attempt in 1954 to mine uraninite-bearing pegmatites in the Idaho Springs district was not successful, but it did yield a small quantity of uraninite concentrate (table 1).

Pitchblende was first discovered in the United States in 1871, when Pearce (1898) found it on the dump of the Wood mine on Quartz Hill. Prior to that time the black oxide of uranium had been thrown away by the miners, for it generally contained but little gold and the mill men objected to it, apparently because of its high
TABLE 1.-Uranium production from the Central City district and adjoining areas, 1871-1955

\begin{tabular}{|c|c|c|c|}
\hline Year & $\begin{array}{l}\text { eshipped } \\
\text { (tons) }\end{array}$ & $\mathrm{U}_{3} \mathrm{O}_{8}$ (pounds) & Mine \\
\hline $\begin{array}{l}1871 \ldots \\
1872 \\
1873 \\
1884 \\
1894 \\
1897 \\
1898 \\
1899 \\
1900 \\
1905-06 \\
1909 \\
1910 \\
1911 \\
1912 \\
1913 \\
1914 \\
1916 \\
1919 \\
1921 \\
1927 \\
1933 \\
1940 \\
1953 \\
19547\end{array}$ & $\begin{array}{c}0.1 \\
3.1 \\
2.7 \\
3.0 \\
-34.25 \\
41.0 \\
43.0 \\
6.58 \\
120.0 \\
.8 \\
.8 \\
.25 \\
.12 \\
6.43 \\
50.0 \\
10.0 \\
8.0 \\
31.5 \\
(5) \\
.5 \\
17.5 \\
14.3\end{array}$ & $\begin{array}{c}120 \\
3,720 \\
2,254 \\
4,200 \\
-35,150 \\
15,920 \\
10,750 \\
2,106 \\
21,000 \\
480 \\
480 \\
150 \\
90 \\
712 \\
1,490 \\
12,000 \\
11,520 \\
(4) \\
--14 \\
135 \\
800 \\
136.1 \\
\\
007\end{array}$ & \multirow[t]{2}{*}{$\begin{array}{l}\text { Wood. } \\
\text { Do. } \\
\text { Do. } \\
\text { Do. } \\
\text { Do. } \\
\text { Wood or Kirk. } \\
\text { Do. } \\
\text { Do. } \\
\text { Do. } \\
\text { Kirk. } \\
\text { Belcher. } \\
\text { German. } \\
\text { Do. } \\
\text { West Calhoun. } \\
\text { Belcher. } \\
\text { Kirk. } \\
\text { Wood. } \\
\text { Jo Reynolds. }{ }^{2} \\
\text { Fairfield. } \\
\text { German. } \\
\text { Do. } \\
\text { Wood. } \\
\text { East Calhoun. }{ }^{\circ} \\
\text { Carroll, Two Sisters, }{ }^{8} \\
\text { and Martha E. } \\
\text { Carroll }{ }^{8} \text { and Bonanza. }\end{array}$} \\
\hline$\because$ Total & 386.93 & $123,510.8$ & \\
\hline
\end{tabular}

1 Production for years 1871-1940, except as noted, complled by F. C. Armstrong,

Geol. Survey.
3 Harrison and Leonard (1952, p. 7).

4 Grade not known.

- Small production; tonnage and grade not known.

- Drake (1957); ore was not shipped. lander claim, Idaho springs district, that contained 253.6 pounds $\mathrm{U}_{3} \mathrm{O}_{8}$. Published by permission of Uncompahgre Mining Co.

Published by permission of United Mining and Leasing Corp.

- Harrison and Wells (1959)

作

specific gravity which caused it to hang to the plates and scour the amalgam. Pearce hand-sorted 200 pounds of pitchblende from the Wood dump which he sold abroad, reportedly for $\$ 210$. The following year he mined pitchblende ore from the lens left by the previous operator and recovered about 3 tons of 60 percent $\mathrm{U}_{3} \mathrm{O}_{8}$ ore, which reportedly sold for $\$ 7,500$. Small tonnages were extracted from the mine in 1873 and 1884, all high in grade. In 1894 a lessee reopened the Wood mine, and in driving a drift west from the old shaft he encountered another lens of pitchblende-bearing ore, but its gold content was low and the lens was abandoned. In 1897 and 1898 some high-grade ore was taken from both the Wood and Kirk mines; additional ore was extracted in 1899, 1900, 1905-06, and later years. From 1909 to 1913 small quantities of pitchblende-bearing ore were produced from the German, Belcher, and West Calhoun mines. In 1919, 8 tons of pitchblende ore that assayed 72 percent $\mathrm{U}_{3} \mathrm{O}_{8}$ was mined at the Jo Reynolds mine (Harrison and Leonard, 1952, p. 7) ; the ore was sold in 
France by R. B. Morton, owner, reportedly for $\$ 80,000$. In 1921, the Fairfield mine in upper Russell Gulch reportedy produced 1.5 tons of pitchblende-bearing ore, but this is not confirmed nor is the disposition of the ore known (G. B. Guillotte, written communication, 1945). During the late twenties and the thirties a few hundred pounds of pitchblende-bearing ore was mined at the German mine by G. F. Grutzmacher, and in 1940 a small quantity was taken from the Wood mine (Drake, 1957).

Since World War II, only small quantities of uranium ore have been produced from the region, although the search for uranium in the area has been greater than at any previous time. The production during 1952-55 was 54.3 tons of ore that contained $1,233.8$ pounds of $\mathrm{U}_{3} \mathrm{O}_{8}$.

Since World War II, Federal agencies have provided some financial assistance, as well as technical advice, to mining companies which are exploring for uranium. The Defense Minerals Exploration Administration financed exploration projects at the Wood-East Calhoun (Drake, 1957), German, and Martha E mines, and the Atomic Energy Commission financed small exploration projects at the Cherokee and Springdale mines in the Central City district and at the Golconda, Almaden, and Mary mines in the Fall River area. In 1952 the discovery of radioactive ores, on some dumps in the Eureka Gulch area by the Geological Survey (Sims and others, 1955) led to the opening of the Carroll, Two Sisters, Claire Marie, St. Anthony, and R.H.D. mines; subsequently this group of mines has produced small quantities of uranium ore. The ore shipped from the Carroll mine was partly hand-sorted and shipped as crude ore, and partly beneficiated by gravity concentration on a Wilfley table. So far as known the concentration of pitchblende ore from the Carroll mine at the Black Eagle mill in Idaho Springs was the first successful operation of this type in the United States that yielded shippable quantities of uranium ore. Small quantities of ore also have been mined at the Cherokee, Wood-East Calhoun, Springdale, and Martha $\mathrm{E}$ mines, and at the Blackhawk Lode No. 2 claim on Silver Hill. A search for radioactive pegmatites was started in 1954 , when a private mining company started exploration and mining of a radioactive pegmatite on the Highlander claim in Virginia Canyon, but through 1956 only the Highlander and adjacent Hudson properties had been mined on a substantial scale. In December 1954, the operator shipped a carload of hand-sorted radioactive pegmatite from the properties, but the ore was too low in grade to be accepted at the mill.

\section{GEOLOGIC SETTING}

The mining districts in the central part of the Front Range mineral belt are in a terrane of complexly folded

Precambrian crystalline rocks, which constitute the core of the Front Range. These districts are also near intrusive centers of early Tertiary (Laramide) igneous rocks. The ore deposits were derived from the early Tertiary intrusives and are precious-metal-bearing sulfide-quartz veins that are dominantly fissure fillings (pl. 1). The veins are chiefly valuable for their gold. Uranium-bearing minerals are local constituents of the veins and constitute a small amount of the dollar value of the ores.

\section{ROCK UNITS}

\section{PRECAMBRIAN ROCKS}

The Precambrian rocks are an interlayered and generally comformable sequence of metasedimentary gneisses, migmatite, and igneous rocks (table 2). A generalized geologic map that shows the gross distribution of the major rock units of the area and the principal fold axes is given in figure 3. Additional data on the rocks are given in a report by Moench and others (1962) and in the reports on the separate mining districts.

TABle 2.-Principal Precambrian rock units in the central part of the Front Range mineral belt, in order of probable age, listed from youngest to oldest

\begin{tabular}{|c|c|}
\hline Rock units & Comments \\
\hline \multicolumn{2}{|c|}{ Igneous rocks } \\
\hline $\begin{array}{l}\text { Pegmatite } \\
\text { Biotite-muscovite granite } \\
\text { Quartz diorite and associated } \\
\text { hornblendite } \\
\text { Granodiorite }\end{array}$ & $\begin{array}{l}\text { Equivalent to Silver Plume gran- } \\
\text { ite, Silver Plume, Colo. } \\
\text { Probably equivalent to Boulder } \\
\text { Creek granite of Lovering and } \\
\text { Goddard (1950). }\end{array}$ \\
\hline
\end{tabular}

\begin{tabular}{l|l} 
Rocks of uncertain origin \\
\hline Granite gneiss and pegmatite & $\begin{array}{l}\text { Also constitute felsic layers in } \\
\text { migmatites. Unit contains } \\
\text { rocks in part younger than } \\
\text { some or all of the above units. }\end{array}$ \\
\hline
\end{tabular}

\section{Medasedimentary rocks 1}

Microcline-quartz-plagioclase-biotite gneiss Quarts diorite gneiss Cordierite-amphibole gneiss

Biotite-quartz-plagioclase gneiss

Sillimanitic biotite-quartz gneiss

Lime silicate gneiss

Skarn and related rocks

Amphibolite

Quartzite (or quartz gneiss)

1 The age relations among the metasedimentary rocks are imperfectly known.
The microcline-bearing gneiss is the granite gneiss of Bastin and Hill (1917); it was referred to in a previous report (Sims, 1956a) as quartz monzonite gneiss. Most of the other rocks previously were grouped in the Idaho Springs formation of Ball (1906). 


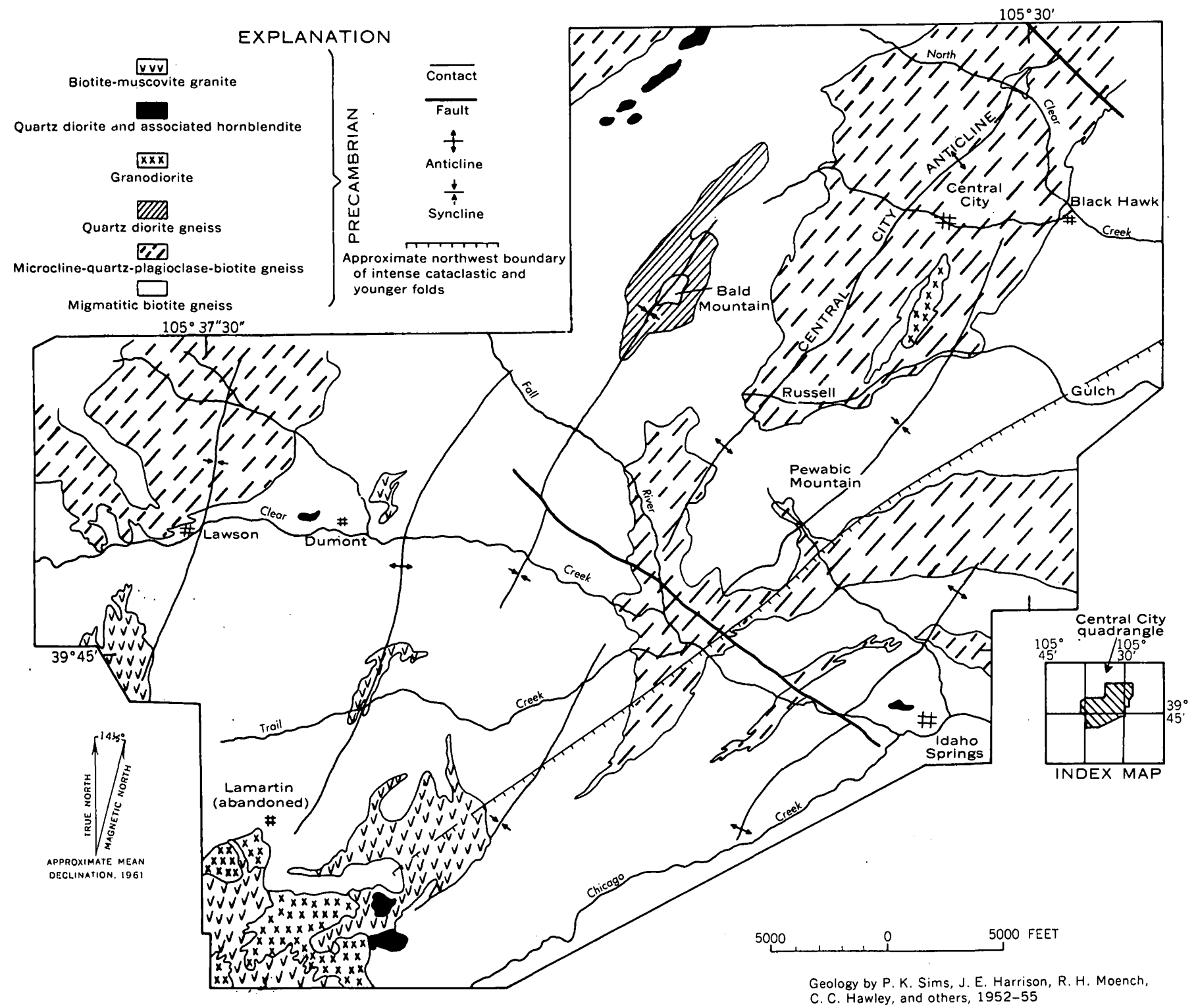

Fiaure 3.-Generalized geologic map of the Precambrian rocks, central part of the Front Range mineral belt, Colorado.

The oldest rocks are metasedimentary gneisses that are mainly feldspathic-quartzose rocks but include some lime silicate rocks. Biotite-quartz-plagioclase gneiss and sillimanitic biotite-quartz gneiss, which are interlayered on a small scale, and microcline-quartz-plagioclase-biotite gneiss are the most abundant of these rocks. The other metasedimentary rocks occur mainly as lenses or pods in the dominant rock units. The microclinequartz-plagioclase-biotite gneiss is referred to throughout this report as microcline-bearing gneiss. This unit was mapped previously as granite gneiss by Bastin and Hill (1917) and as either granite gneiss or quartz monzonite gneiss by Lovering and Goddard $(1950$, pl. 2$)$. Individual layers of the units range from a few hundred to as much as 4,000 feet in thickness; the total maximum thickness of the lithologic succession is estimated to be less than 15,000 feet.

The biotite gneisses are migmatized throughout the region; that is, they contain variable quantities of granite gneiss and pegmatite, either as an intimate intercalation or as larger, discrete bodies. Migmatization is most intense in the southern part of the region, and in these areas the granite gneiss and pegmatite unit constitutes mappable bodies (Harrison and Wells, 1956; 1959). The granite gneiss and pegmatite unit is not shown, however, in figure 3 of this report.

The rocks younger than the migmatite and granite gneiss and pegmatite unit intrude the older rocks. Granodiorite forms moderate-sized nearly conformable bodies; quartz diorite and associated hornblendite forms 
small generally conformable bodies; and biotite-muscovite granite forms small or moderate-sized, grossly conformable but locally crosscutting bodies.

Pegmatites of various types and ages are abundant, especially in the biotite gneisses. Most of the pegmatites are unzoned and relatively simple in mineralogy. Pegmatite that contains accessory magnetite or biotite and belongs to the granite gneiss and pegmatite unit (table 2) occurs both as thin layers intercalated with the biotite gneisses and as larger, generally conformable, discrete bodies. A distinct mineralogic variety that also forms migmatites is confined to the northeast part of the area, in the vicinity of Black Hawk; it contains muscovite and black tourmaline rather than biotite and magnetite. Locally in the Central City district a xenotime- and monazite-bearing pegmatite forms migmatites in biotite gneisses, but this type of pegmatite is neither abundant nor widespread areally (Young and Sims, 1961). Pegmatites that are geographically associated with, and probably genetically related to, granodiorite and biotite-muscovite granite occur in joints within the larger bodies of these rocks. A pegmatite that is characterized by coarse books of mica, a low quartz content, and abnormal quantities of uraninite possibly is related to the biotite-muscovite granite. The pegmatite forms many small lenticular bodies and in particular is moderately abundant in a narrow zone extending from the mouth of Trail Creek northeast to the eastern margin of the mapped area.

\section{TERTIARY INTRUSIVE ROCKS}

The Tertiary intrusive rocks constitute an integral part of the sequence of porphyritic igneous rocks within the Front Range-mineral belt. The belt extends from Breckenridge to Jamestown, diagonally across the Precambrian core of the Front Range. These rocks vary widely in form and composition (Lovering and Goddard, 1938, p. $36 ; 1950$, p. 43-47).

The intrusive rocks in the central part of the mineral belt have been divided by Wells (1960) into 13 mappable units (fig. 4).

These rock units have been classified further according to similarities in age, petrography, and close geographic distribution into four groups-light-colored granodiorite porphyry, quartz monzonite porphyry, bostonite porphyry, and hornblende granodiorite porphyry. The younger members are somewhat finer grained than the older members and at places show narrow chilled borders. The distribution of the various intrusive rocks is shown on plate 1 .

The light-colored granodiorite porphyry group consists of light-colored granodiorite porphyry, albite

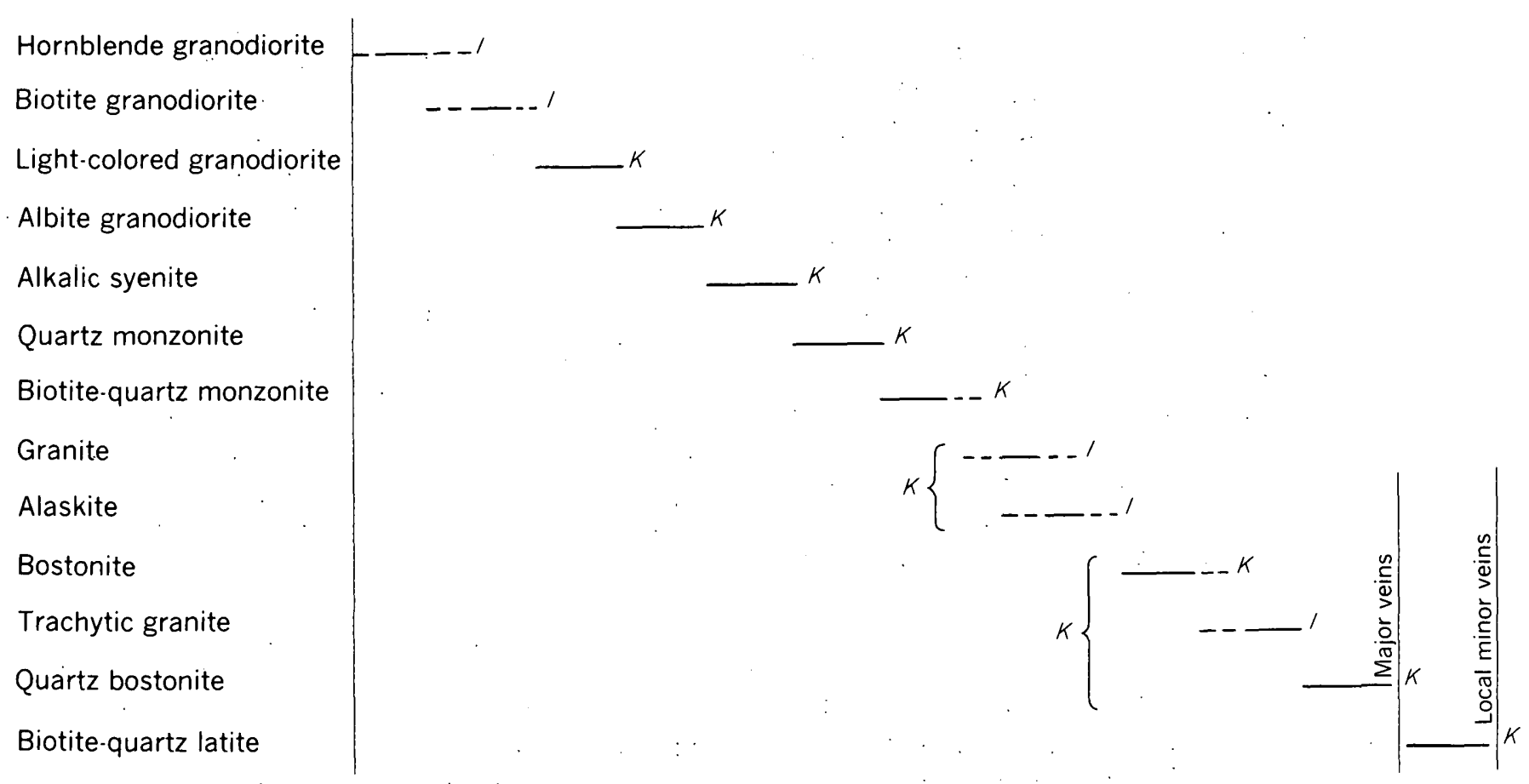

Age known from field relations, $K$; age inferred in this report, /

Figure 4.-Diagram showing probable sequence of intrusion of the porphyritic Tertiary igneous rocks. 
granodiorite porphyry, and alkalic syenite porphyry. These rocks are confined mostly to the southeastern part of the Central City district and the northeastern part of the Idaho Springs district. They occur as small irregular plutons and dikes; the dikes commonly radiate outward from the larger bodies. Breccia fragments of Precambrian wallrocks occur within some of the larger plutons.

The quartz monzonite porphyry group, which consists of quartz monzonite porphyry, granite porphyry, and alaskite porphyry is widespread, but is most abundant in the Idaho Springs and Central City districts. Its distribution is similar to that of the light-colored granodiorite porphyry group. A large body of intrusion breccia is associated with a plug of quartz monzonite porphyry in Chase Gulch, in the northern part of the Central City district.

The bostonite porphyry group-bostonite porphyry, trachytic granite porphyry, and quartz bostonite porphyry -is present throughout the region but is most abundant in the Central City district. The members of the group are distinguished by a characteristic reddishbrown or lilac color and by a trachytic texture. A variety of bostonite porphyry that is common in the Freeland-Lamartine district contains scattered garnets.

The hornblende granodiorite porphyry grouphorr.jlende granodiorite porphyry, biotite granodiorite porphyry, biotite-quartz monzonite porphyry, and biotite-quartz latite porphyry-is restricted to the eastern part of the Lawson-Dumont-Fall River district, the Chicago Creek district, and the southern part of the Idaho Springs district. The biotite-quartz latite porphyry, as noted in figure 4, was emplaced after the development of the major vein fissures.

Wells (1960) has assumed that the Tertiary igneous rocks consolidated from two magma series which cooled virtually simultaneously, a minor series consisting of the rocks of the hornblende granodiorite porphyry group and a major series consisting of the rocks of the light-colored granodiorite porphyry, quartz monzonite porphyry, and bostonite porphyry groups. Judging from the mineralogy of the rocks, the two magmas had similar intermediate compositions, but the minor series contained more iron and magnesium. Differentiation of each magma series was in the normal sequence from mafic to felsic phases.

\section{RADIOACTIVITY OF COUNTRY ROCKS}

Aside from biotite-muscovite granite, local varieties of biotite gneiss, and certain pegmatites, the Precambrian rocks have a uniformly low natural radioactivity. The Tertiary intrusive rocks, however, have a variable but generally high radioactivity; quartz bostonite porphyry ranks among the most radioactive igneous rocks in the world, according to Larsen and Phair (1954, p. 87).

\section{PRECAMBRIAN ROCKS}

Although systematic uranium and thorium analyses by precise analytical methods have not been made, most Precambrian rocks of the region are known to have a low natural radioactivity. With one exception the abnormally radioactive rocks are of igneous origin. The radioactivity largely results from thorium in monazite or xenotime, but in one type of pegmatite it results from uranium.

\section{THORIUM- AND RARE-EARTH-BEARING GNEISS AND MIGMATITE}

Local concentrations of xenotime and monazite of potential economic importance are known in biotite gneiss and migmatite at two localities in the Central City district. As these deposits are described in a separate report (Young and Sims, 1961), they are only summarized here.

Concentrations of xenotime and monazite in a quartzrich phase of biotite-quartz-plagioclase gneiss are present on the east side of Fourmile Gulch, about fourfifths of a mile northeast of Black Hawk. This occurrence has been prospected as a potential source of the rare-earth metals. Concentrations of the same minerals in migmatite are found near the Jasper Cuts, just south of Lake Gulch and four-fifths of a mile south of Central City. Locally, pegmatite-rich phases of the migmatite have been mined for xenotime. The two deposits are probably correlative, for they are stratigraphically about 100 feet above the base of the thick unit of migmatized biotite gneisses that lie above the 3,000-foot-thick layer of microcline-bearing gneiss that crops out along the axis of the Central City anticline (fig. 3).

In the biotite gneiss, the xenotime and monazite are concentrated into lenticular bodies having a maximum thickness of about 3 feet and a maximum strike length of about 100 feet. Where developed, the deposits contain 1 to 3 percent by volume of the minerals, with xenotime predominating over monazite. The minerals are irregularly dispersed through the rock but occur mainly in coarse biotite and magnetite.

In the migmatite at the Jasper Cuts, the xenotime and monazite are concentrated largely in coarse layers and clots of biotite that are irregularly dispersed through the pegmatite phase. The pegmatite that was mined contained 3 to 5 percent xenotime and monazite combined; other parts of the pegmatite in the area are abnormally radioactive but generally contain only 1 or 2 percent of the radioactive minerals. Probably 
the xenotime- and monazite-bearing pegmatite obtained the radioactive minerals from the biotite gneiss country rock which it invaded. During migmatization of the country rock, the pegmatite that formed in the xenotime- and monazite-rich zone of the biotite gneisses incorporated these radioactive minerals through contamination. The minerals were concentrated in biotite layers and clots that form thin septa in the pegmatite.

The radioactivity of the rare-earth-bearing gneiss and migmatite varies widely, but certain zones within the deposits emit as much as $1.5 \mathrm{mr}$ per hr (milliroentgens per hour). Analyses for radioactivity as well as for the thorium, uranium, and rare-earth content are given in table 3 . These analyses indicate that the rare-earth and thorium content of the deposit is high and that the yttrium-group elements are more abundant than the cerium-group elements, as indicated mineralogically by the predominance of xenotime over monazite. Other analyses of pegmatite grab samples from the Jasper Cuts area are given below :

TABLE 3.-Semiquantitative spectrographic, radiometric, and chemical analyses of thorium-and rare-earth-bearing biotite gneiss, in percent, and migmatite, Central City district

[Analyses by U.S. Geol. Survey; spectrographic analyses by J. C. Hamilton and R. G. Havens]

\begin{tabular}{|c|c|c|c|c|c|c|c|c|c|c|c|c|c|c|c|c|c|c|c|c|c|}
\hline Sample & $\begin{array}{c}\text { Labora- } \\
\text { tory } \\
\text { serial } \\
\text { No. }\end{array}$ & \multicolumn{2}{|c|}{$\begin{array}{c}\text { Equiva- } \\
\text { lent } \\
\text { uranium } 1\end{array}$} & U & $\mathrm{Th}$ & $\mathbf{Y}$ & $\mathbf{L a}$ & $\mathrm{Ce}$ & $\operatorname{Pr}$ & $\mathrm{Nd}$ & $\mathrm{Sm}$ & $G d$ & $\mathbf{T b}$ & Dy & Ho & $\mathbf{E r}$ & $\mathrm{Tm}$ & Lu & $\mathrm{Fe}$ & $\mathbf{M g}$ & $\mathrm{Ca}$ \\
\hline $\begin{array}{l}\text { SH-2 } \\
4-1 \\
\text { MCC } 1 \\
\text { MCC-2 }\end{array}$ & $\begin{array}{l}249869 \\
260436 \\
256742 \\
256743\end{array}$ & \multicolumn{2}{|c|}{$\begin{array}{c}\text { n.d. } \\
0.018 \\
.065 \\
.22\end{array}$} & $\begin{array}{r}\text { n.d. } \\
\text { n.d. } \\
20.022 \\
2.070\end{array}$ & \begin{tabular}{|l|}
0.3 \\
.07 \\
3.18 \\
3.66
\end{tabular} & $\begin{array}{r}1.5 \\
.3 \\
1.5 \\
3.0\end{array}$ & $\begin{array}{l}0.3 \\
.07 \\
.3 \\
.7\end{array}$ & $\begin{array}{c}0.3 \\
.15 \\
.7 \\
1.5\end{array}$ & $\begin{array}{l}0.07 \\
.015 \\
.15 \\
.3\end{array}$ & \begin{tabular}{l|l}
7 & 0.3 \\
15 & .07 \\
5 & .3 \\
& .7
\end{tabular} & $\begin{array}{l}0.07 \\
0.15 \\
.3\end{array}$ & $\begin{array}{l}0.15 \\
.03 \\
.15 \\
.3\end{array}$ & $\begin{array}{c}<0.07 \\
0 \\
0 \\
0\end{array}$ & \begin{tabular}{l|}
0.15 \\
.03 \\
.15 \\
.3
\end{tabular} & $\begin{array}{l}0.03 \\
.015 \\
.07 \\
.15\end{array}$ & \begin{tabular}{l|l}
0.15 & 0 \\
.03 & \\
.15 & \\
.3 &
\end{tabular} & \begin{tabular}{c|}
0.015 \\
.007 \\
.015 \\
.07
\end{tabular} & $\begin{array}{l}0.15 \\
.03 \\
.15 \\
.3\end{array}$ & $\begin{array}{r}>10.0 \\
7.0 \\
3.0 \\
7.0\end{array}$ & $\begin{array}{r}1.5 \\
1.5 \\
.7 \\
.7\end{array}$ & $\begin{array}{l}0.15 \\
1.5 \\
1.5 \\
1.5\end{array}$ \\
\hline Sample & $\begin{array}{c}\text { Labora- } \\
\text { tory } \\
\text { serial } \\
\text { No. }\end{array}$ & $\mathrm{Na}$ & $\mathbf{K}$ & $\mathbf{T i}$ & $\mathbf{P}$ & Mn & $\mathrm{Ba}$ & $\mathrm{Be}$ & & Co & $\mathrm{Cr}$ & $\mathrm{Cu}$ & $\mathrm{Ga}$ & $\mathrm{Nb}$ & $\mathrm{Ni}$ & $\mathrm{Pb}$ & Sc & Sn & $\mathrm{Sr}$ & V & $\mathbf{Z r}$ \\
\hline $\begin{array}{l}\text { SH }-2 \ldots \\
4-1 \\
\text { MCC-1 } \\
\text { MCC-2 }\end{array}$ & $\begin{array}{l}249869 \\
260436 \\
256742 \\
256743\end{array}$ & $\begin{array}{l}0.3 \\
3.0 \\
3.0 \\
3.0\end{array}$ & $\begin{array}{l}3.0 \\
3.0 \\
3.0 \\
3.0\end{array}$ & $\begin{array}{l}0.7 \\
.7 \\
.3 \\
.7\end{array}$ & $\begin{array}{c}40.35 \\
0 \\
.3 \\
.7\end{array}$ & $\begin{array}{l}0.15 \\
.15 \\
.07 \\
.07\end{array}$ & $\begin{array}{l}0.03 \\
.03 \\
.03 \\
.03\end{array}$ & $\begin{array}{l}0 \\
0 \\
0\end{array}$ & & $\begin{array}{c}0.003 \\
.003 \\
.0007 \\
<.001\end{array}$ & $\begin{array}{l}0.07 \\
.015 \\
.015 \\
.015\end{array}$ & $\begin{array}{l}0.0015 \\
.7 \\
.015 \\
.015\end{array}$ & $\begin{array}{r}<0.007 \\
.003 \\
.003 \\
.007\end{array}$ & $\begin{array}{l}0.003 \\
.003 \\
0 \\
0\end{array}$ & $\begin{array}{l}0.015 \\
.015 \\
.007 \\
.007\end{array}$ & $\begin{array}{l}0.03 \\
.015 \\
.03 \\
.07\end{array}$ & $5 \mid \begin{array}{l}0.003 \\
.003 \\
0 \\
0\end{array}$ & \begin{tabular}{l|l}
3 & 0.007 \\
3 & .0015 \\
& 0 \\
& 0
\end{tabular} & $\begin{array}{l}0.0015 \\
.015 \\
.015 \\
.015\end{array}$ & $\begin{array}{l}0.03 \\
.015 \\
.007 \\
.015\end{array}$ & $\begin{array}{l}0.15 \\
.07 \\
.07 \\
.15\end{array}$ \\
\hline
\end{tabular}

1 Radiometric analyses by $G$. S. Erickson.

2 Chemical analyses by D. L. Ferguson and W. W. Niles.

3 Determined by radiochemical analysis (J. N. Rosholt, Jr.).

Determined by chemical analysis (I. $P$. Schuch). SH-2.
Gulch.

4-1. 5-ft chip sample across radioactive zone in biotite-quartz-plagioclase gneiss, Fourmile Gulch.

MCC-1. Grab sample of radioactive pegmatite taken from pit that yielded about 100 tons of xenotime-rich ore, $500 \mathrm{ft}$ southwest of Jasper Cuts.

MCC-2. Grab sample from same locality as MCC-1.

n.d. means not determined.

Analyses, in percent, of thorium-and rare-earth-bearing pegmatite, Jasper Cuts area

[Analysts: J. P. Schuch, H. E. Bivens, S. P. Furman, James Wahlberg, W. D. Goss, Wayne Mountjoy, U. S. Geol. Survey]

\begin{tabular}{|c|c|c|c|c|c|}
\hline Sample & $\begin{array}{l}\text { Laboratory } \\
\text { serial no. }\end{array}$ & $\begin{array}{l}\text { Equiva- } \\
\text { lent } \\
\text { uranium }\end{array}$ & Uranium & $\begin{array}{l}\text { Tho- } \\
\text { rium }\end{array}$ & Locality \\
\hline $\begin{array}{l}\text { JC-1 } \\
\text { K-19.-- } \\
\text { SM-1 }\end{array}$ & $\begin{array}{r}220394 \\
\mathrm{D}-95432 \\
220395\end{array}$ & $\begin{array}{r}0.055 \\
.031 \\
.038\end{array}$ & $\begin{array}{r}0.012 \\
.009 \\
.009\end{array}$ & $\begin{array}{l}0.24 \\
\text { n.d. } \\
\text { n.d. }\end{array}$ & $\begin{array}{l}\text { Jasper Cuts. } \\
\text { Do. } \\
650 \mathrm{ft} \text { southwest }\end{array}$ \\
\hline $\mathrm{K}-12 \ldots$ & $\mathrm{D}-95430$ & .023 & .008 & n.d. & Do. \\
\hline
\end{tabular}

n.d. means not determined.

\section{URANIUM-BEARING PEGMATITE}

Radioactive pegmatites that contain disseminated uraninite and which are commonly 40 to 50 times as radioactive as most Precambrian gneisses and granites are widely distributed in the Idaho Springs district in a belt that extends from the mouth of Trail Creek northeast through Virginia Canyon. The location of this belt
The following notes apply to the semiquantitative spectrographic analyses: Looked for but not found: Ag, As, Au, B, Bi, Cd, Eu, Ce, Hf, Hg, In, Ir, Li, Mo, Os, Pd, Pt, Re, Rh, Ru, Sb, Sn, Ta, Te, Tl, w, Zn. in percent.

(he nearest number in the series $7,3,1.5,0.7,0.3,0.15$, 60 percent of the repo
quantitative methods.

is shown on plate 3 , but specific occurrences are not shown. Similar radioactive pegmatite also has been noted on the dump of the Waterloo mine, in upper Russell Gulch, Central City district, and locally in the Fall River area. The pegmatite on the Highlander claim in the Idaho Springs district has been mined as a source of uranium ore, but the operation was not profitable.

The radioactive pegmatites in the Idaho Springs district occur as discontinuous bodies within the eastnortheastward-trending layer of microcline-quartzplagioclase-biotite gneiss that crops out $11 / 2$ miles north of Idaho Springs (fig. 3). Most known pegmatite bodies are in the lower (southern) part of the layer, but a few are stratigraphically higher. Analyses of selected samples from the known pegmatite localities in the belt, except the Highlander claim, are given in table 4. Generally these analyses represent the more highly radioactive parts of the pegmatites and do not represent average grades. 
TABLE 4.-Analyses of uraninite-bearing pegmatites, in percent, Idaho Springs district (exclusive of Highlander claim) ${ }^{1}$

[Analyses by U.S. Geol. Survey]

\begin{tabular}{|c|c|c|c|c|}
\hline Samplo & $\begin{array}{l}\text { Laboratory } \\
\text { sorlal no. }\end{array}$ & $\begin{array}{c}\text { Equivalent } \\
\text { uranlum }\end{array}$ & Uranlum & Locality \\
\hline Pat-1. & 220393 & 0.037 & 0.044 & Small pit on Patten \\
\hline $3-269$ & 221568 & .021 & .016 & Dump, Fourth of \\
\hline $\begin{array}{l}3-76--- \\
3-421_{-}\end{array}$ & $\begin{array}{l}221573 \\
221576\end{array}$ & .020 & $\begin{array}{l}.020 \\
.002\end{array}$ & $\begin{array}{l}\text { Dump, Ashland mine. } \\
\text { Dump, Little Emma }\end{array}$ \\
\hline LE-1. & 225234 & .073 & .048 & Underground, Little \\
\hline $4-J_{-}$ & 225233 & .022 & .010 & $\begin{array}{l}\text { Underground, Fourth } \\
\text { of July mine. }\end{array}$ \\
\hline NB-1 & 227396 & .037 & .057 & Underground, New \\
\hline NB-2. & 227397 & .017 & .014 & Do. \\
\hline
\end{tabular}

I All aro grab samples. Analysts: . Ann Sweeney, Carmen Johnson, Percy Moore, Angolo, and Mary Finch.

To determine the geology of the uraninite-bearing pegmatite bodies in one part of the belt, a detailed survey was made of the Highlander and adjacent mining claims in the vicinity of Robinson Gulch, $12 / 3$ miles north of Idaho Springs. A detailed outcrop map showing the distribution of radioactive pegmatite (fig. 5) and the general relations of the pegmatite to other rock units was made by planetable methods, and the accessible underground workings were mapped and investigated systematically for radioactivity.

The radioactive pegmatites on the Highlander and adjacent claims are generally conformable bodies in interlayered biotite gneisses and amphibolite, which constitute a 450 -foot-wide zone in the thick layer of microcline-bearing gneiss. Other pegmatite lenses of similar uranium content occur about 700 feet to the south, on the Patten claim (see table 4), near the southern edge of the microcline-bearing gneiss layer. The pegmatite lenses range from less than 1 to about 50 feet in width and from a few feet to several tens of feet in length, and most of them contain thin layers of the metamorphic gneisses.

The pegmatites are white, buff, or pink unzoned bodies that consist dominantly of feldspar, quartz, and biotite. The biotite forms irregular-shaped books that show little if any preferred orientation and which tend to be clustered. The feldspar and biotite crystals are commonly 1 inch or less in diameter. The feldspar is dominantly plagioclase (oligoclase) and microcline; modal analyses of several polished hand specimens indicate that microcline exceeds plagioclase in volume. The plagioclase has a fine albite twinning; the microcline has a conspicuous grid structure and locally is perthitic. At places feldspar and quartz are intergrown in a graphic texture. The quartz occurs as aggregates of tiny grains that generally have a mosaic pattern and which are largely interstitial to the feldspar crystals. The common accessory minerals, in addition to uraninite, are molybdenite, pyrite, galena, chalcopyrite, and hematite.

The pegmatites and associated rocks are cataclastically deformed; at places the deformation was sufficiently intense to form a fine-grained, streaked mylonite. The feldspars are strained, locally broken, and altered, and mortar textures are common. The biotite is flexed, bent, and locally broken; it is altered to a claylike mineral along the fractures and along grain boundaries. The cataclasis was produced during the younger period of Precambrian deformation (see p. 14).

The uraninite occurs as tiny cubic crystals disseminated through the rock; it is most abundant in biotite, but also occurs in the feldspar. Its distribution leaves no doubt that it is a primary constituent of the pegmatite. Molybdenite, pyrite, galena, chalcopyrite, and hematite, however, occur along fractures in the rock and were introduced during or after the cataclasis.

Although sampling has not been sufficient to determine adequately the bulk grade of the pegmatite bodies, the writers estimate that the grade of single bodies ranges from about 0.01 to as much as 0.06 percent uranium (table 5) and probably averages about 0.04 per-

TABLE 5.-Analyses, in percent, of uraninite-bearing pegmatite from the Highlander claim, Idaho Springs district [Analyses by U.S. Geol, Survey] ${ }^{1}$

\begin{tabular}{|c|c|c|c|c|}
\hline Sample & $\begin{array}{c}\text { Labora- } \\
\text { tory serial } \\
\text { no. }\end{array} \mid$ & $\begin{array}{l}\text { Equiva- } \\
\text { lent } \\
\text { uranium }\end{array}$ & Uranium & Location and description of sample \\
\hline$A-1$ & 211527 & 0.89 & 1.11 & $\begin{array}{l}\text { Stockpile of broken ore, loc. 1; } \\
\text { dominantly uranophane-bearing } \\
\text { ore. }\end{array}$ \\
\hline A-2 & 211528 & .18 & .23 & $\begin{array}{l}\text { Do. } \\
\end{array}$ \\
\hline H-1... & 216710 & .048 & .035 & $\begin{array}{l}\text { Stockpile mined from Hudson } \\
\text { tunnel; uraninite-bearing ore. }\end{array}$ \\
\hline H-2... & 216711 & .14 & .12 & $\begin{array}{l}\text { Stockpile of coarse broken ore from } \\
\text { Hudson tunnel. }\end{array}$ \\
\hline $\mathrm{H}-3$ & 216712 & .051 & .061 & $\begin{array}{l}\text { Broken pegmatite from loc. 2; } \\
\text { contains secondary uranium } \\
\text { minerals. }\end{array}$ \\
\hline H-4...- & 216713 & .046 & .036 & $\begin{array}{l}\text { Broken pegmatite from loc. } 3 \text {; } \\
\text { contains secondary uranium } \\
\text { minerals. }\end{array}$ \\
\hline E-A. & 225019 & .011 & .007 & Pegmatite in pit at loc. 4. \\
\hline A-11-1A & 225020 & .21 & .18 & $\begin{array}{l}\text { Selected broken ore at pit, loc. } 1 \text {; } \\
\text { dominantly uranophane-bearing } \\
\text { ore. }\end{array}$ \\
\hline A-5A.- & 225021 & .051 & .013 & Broken pegmatite at pit, loc. 5 . \\
\hline A-13A $\ldots$ & 225022 & .048 & .043 & $\begin{array}{l}\text { Sotckpile of broken pegmatite, loc. } \\
1 .\end{array}$ \\
\hline F-11-2A. & 225023 & .052 & .016 & Pegmatite, loc. 6. \\
\hline F17(16)A $\ldots$ & 225024 & .023 & .036 & $\begin{array}{l}\text { Broken pegmatite at pit, loc. 2; } \\
\text { contains secondary uranium } \\
\text { mineruls. }\end{array}$ \\
\hline $\begin{array}{l}\mathrm{J}-3-\mathrm{A} \\
\mathrm{H} M-1\end{array}$ & 225025 & .051 & .033 & Broken pegmatite at pit, loc. 3. \\
\hline & 220250 & 0.5 & 0.01 & Impure concentrate of uraninite. \\
\hline
\end{tabular}

1 Analysts: J. E. Wilson, S. P. Furman, James Wahlberg, Janet Patton, C. G. Angelo, Mary Finch, Ann Sweeney, R. Smith, and B. McCall.

2 Localities given on figure 4. All are grab samples except HM-1.

3 Contains 0.61 percent $\mathrm{Th}$ and 5.04 percent equivalent $\mathrm{Pb}^{210}$; determined by radiochemical analyses by John Rosholt. 


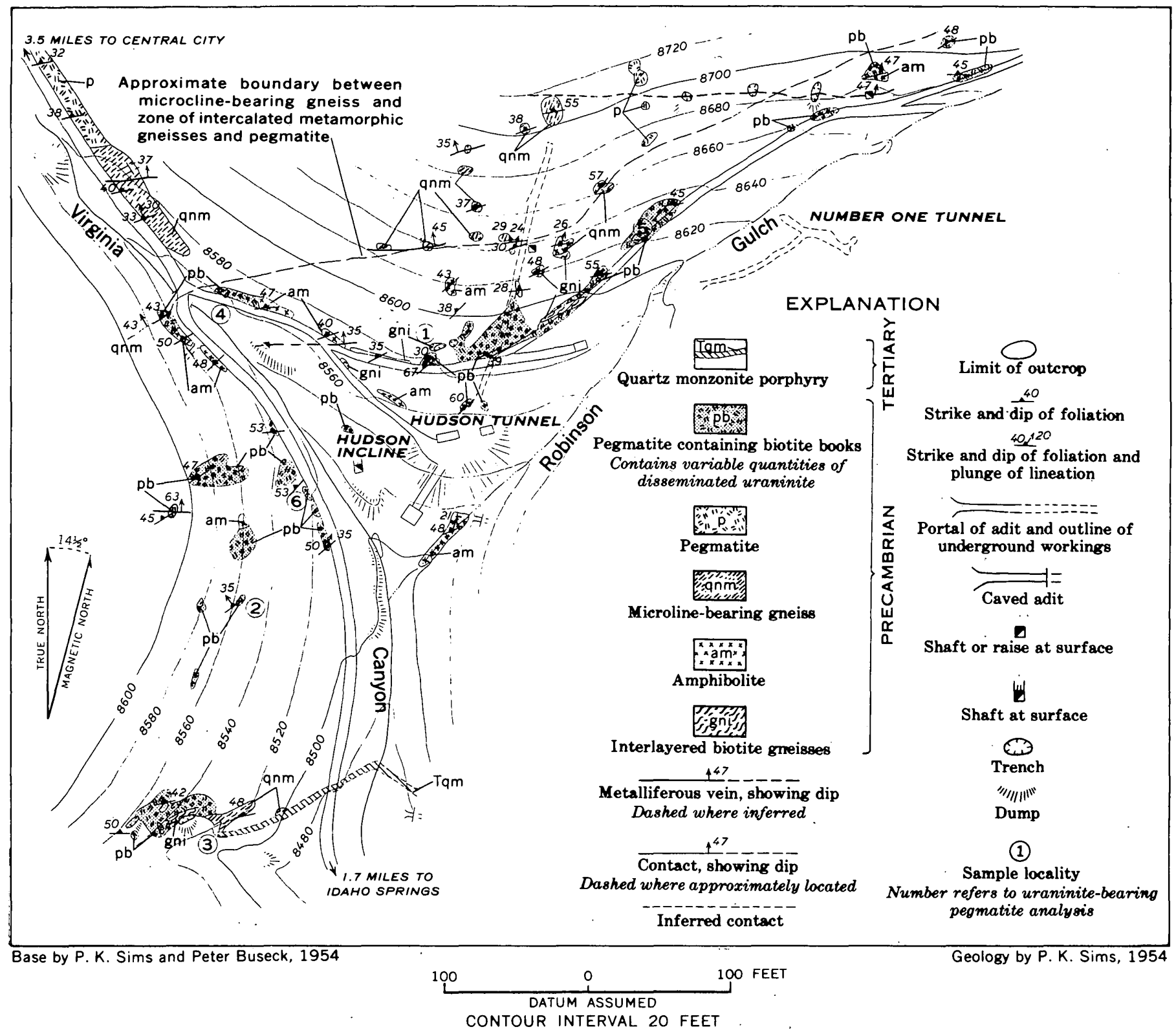

Figure 5.-Outcrop map of the Highlander and adjacent mining claims, Idaho Springs district.

cent. The several pegmatite bodies that have been prospected at the Highlander claim (table 5 and fig. 5) contain an average of 0.03 to 0.04 percent uranium. Certain parts of each pegmatite are higher in grade, however, and by sorting the grade can be raised to about 0.1 percent uranium.

Supergene alteration did not appreciably change the grade of the pegmatites, for grab samples of "run-ofthe-mine". secondary "ore" are virtually the same grade as the primary (unaltered) material.

Attempts to beneficiate the pegmatite mined from the Hudson tunnel on the Highlander claim by gravity concentration on a Wilfley table were not profitable.
A spectrographic analysis of the uranium concentrate (sample HM-1, table 5) by semiquantitative methods (analyst, N. M. Conklin, U.S. Geological Survey) indicates that the concentrate contains $\mathrm{XX}$ percent $\mathrm{Fe}$ and $\mathrm{Pb} ; \mathrm{X}$ percent $\mathrm{Ce} ; 0 . \mathrm{X}$ percent $\mathrm{Si}, \mathrm{Al}, \mathrm{Ti}, \mathrm{Mn}, \mathrm{Ca}, \mathrm{Dy}$, $\mathrm{Gd}, \mathrm{La}, \mathrm{Nd}, \mathrm{Sm}, \mathrm{Th}, \mathrm{Y}, \mathrm{Zn}$, and $\mathrm{Zr} ; 0.0 \mathrm{X}$ percent $\mathrm{Mg}$, $\mathrm{Ag}, \mathrm{Ba}, \mathrm{Bi}, \mathrm{Co}, \mathrm{Cu}, \mathrm{Er}, \mathrm{Mo}, \mathrm{Ni}$, and $\mathrm{Yb}$; and $0.00 \mathrm{X}$ percent $\mathrm{Cr}$ and $\mathrm{V}$.

\section{BIOTITE-MUSCOVITE GRANITE}

The biotite-muscovite granite is 2 to 6 times as radioactive as other Precambrian granites and gneisses in the region, and a representative sample has an equivalent 
uranium content of 0.006 percent. Most of the radioactivity in the granite is due to thorium which occurs in monazite, a common accessory mineral. In the Chicago Creek area, monazite constitutes about 0.4 percent by volume of the biotite-muscovite granite (Harrison and Wells, 1959, table 9). Because of its abnormal radioactivity, biotite-muscovite granite can be distinguished readily from most other granites and gneisses in the region by a scintillation detector.

\section{TERTIARY INTRUSIVE ROCKS}

All the Tertiary intrusive rocks are more radioactive than the average granitic rock, and quartz bostonite porphyry, the most radioactive rock of the sequence, is 15 to 25 times as radioactive as the average granitic rock. Phair (1952) has shown that the radioactivity of the rocks results from both thorium and uranium, that both these elements are co-concentrated with zirconium, and that in the quartz bostonites the $\mathrm{Th} / \mathrm{U}$ ratio is about $6: 1$. A brief summary of Phair's studies up to 1955 is presented by Larsen and others (1956). Using a contoured triangular diagram, the covariation among $\mathrm{K}_{2} \mathrm{O}$, $\mathrm{Na}_{2} \mathrm{O}, \mathrm{CaO}$, and $\mathrm{U}$ is plotted for 45 analyzed Front Range "porphyries," more than half of which came from the area here discussed. This shows that the rocks having the highest uranium content, $30 \mathrm{ppm}$ (parts per million) U, make up a compositional type characterized by an extreme deficiency in $\mathrm{CaO}$. In addition to being exceptionally radioactive these rocks which are poor in $\mathrm{CaO}$ (quartz bostonites) are distinguished readily from all other porphyritic rocks of the Front Range by the presence of alkalic feldspar as the only phenocrysts.

Analyses by routine analytical methods of more than 200 samples from the region indicate that the Tertiary igneous rocks contain an average of 0.006 percent equivalent uranium (radioactivity) and 0.002 percent uranium, but individual rock types depart widely from these averages. The average equivalent uranium and uranium content of the separate rock units as compiled by J. D. Wells are given in table 6. The averages shown in table 6 are arithmetic averages rounded to the third place. The analytical method used to determine uranium has a sensitivity of 0.001 percent.

The analyses compiled by Wells confirm the conclusion of Phair: (1952) that uranium and thorium are greatly enriched in quartz bostonite porphyry. The quartz bostonite porphyry at Central City is particularly enriched in the radioelements. Analysis of 18 samples from this district indicates that this rock has an average equivalent uranium content (radioactivity) of 0.018 percent and an average uranium content of 0.006 percent. Throughout the region the range in equivalent uranium content for the rock, as indicated by analysis of 70 samples, is from 0.002 to 0.024 percent and the range in uranium content is from 0.001 to 0.018 percent. At Central City the range in equivalent uranium content (18 samples) is from 0.010 to 0.024 and the range in uranium content is from 0.003 to 0.018 percent.

TABLE 6.-Average equivalent uranium (radioactivity) and uranium content of the Tertiary intrusive rocks, in percent, central part of the Front Range mineral belt ${ }^{1}$

\begin{tabular}{|c|c|c|}
\hline Rock type 2 & $\begin{array}{c}\text { Equivalent } \\
\text { uranium }\end{array}$ & Uranium 8 \\
\hline $\begin{array}{l}\text { Hornblende granodiorite porphyry } \\
\text { Biotite granodiorite porphyry } \\
\text { Leucocratic granodiorite porphyry } \\
\text { Albite granodiorite porphyry } \\
\text { Alkali syenite porphyry } \\
\text { Quartz monzonite porphyry } \\
\text { Biotite-quartz monzonite porphyry } \\
\text { Granite porphyry } \\
\text { Alkaskite porphyry } \\
\text { Bostonite porphyry } \\
\text { Trachytic granite porphyry } \\
\text { Quartz bostonite porphyry } \\
\text { Biotite-quartz latite porphyry }\end{array}$ & $\begin{array}{l}0.002 \\
.002 \\
.004 \\
.004 \\
.007 \\
.004 \\
.002 \\
.006 \\
.007 \\
.006 \\
.005 \\
.011 \\
.006\end{array}$ & $\begin{array}{l}0.000 \\
.000 \\
.002 \\
.002 \\
.003 \\
.001 \\
.000 \\
.002 \\
.004 \\
.001 \\
.001 \\
.004 \\
.002\end{array}$ \\
\hline
\end{tabular}

1 Compiled by J. D. Wells.

2 Rock types are arranged according to age, from oldest to youngest. (See dlagram, fig. 4.)
3 Analyses by standard chemical methods; sensitivity of method is 0.001 percent.

\section{STRUCTURE}

As the structure of the country rock had a fundamental control on the development of the fracture pattern and on the localization of ore bodies, the principal structural features of the bedrock are summarized in this section. Most emphasis, however; is placed on the faults, which contain the ore bodies. More detailed information on the structure of the country rock is presented by Moench and others (1962) and in the reports on the several mining districts (see "Literature cited").

\section{STRUCTURE OF PRECAMBRIAN ROCKS}

The Precambrian rocks of the region are complexly deformed as a result of two episodes of Precambrian deformation. Large major folds were formed during an early plastic deformation that was accompanied by migmatization and intrusion of the igneous rocks. Minor folds and accompanying granulation were formed locally by a later deformation that occurred after the intrusion of biotite-muscovite granite.

The older folds, formed during the: major period of deformation, define the gross distribution of the rock units in this part of the Front Range (fig. 3). They are dominantly upright open folds, but include upright to overturned tight, recumbent, and rarely chevron folds. The axes of this fold system trend north-northeast to northeast and plunge either to the northeast or the 
southwest; the limbs of the folds generally dip moderately $\left(45^{\circ}\right)$. Several large open folds are present in the region (fig. 3). Among the largest is the Central City anticline, which is the dominant structure in the Central City district. The axis of this fold trends about N. $40^{\circ}$ E. and is doubly plunging.

Upright to overturned tight folds occur locally on the limbs of the major folds. So far as known these folds are relatively small; they commonly have maximum known breadths (wavelength) and heights (amplitudes) of a few hundred feet. The axes of these folds plunge north-northeast to northeast, subparallel to the major fold axes. The axial planes of most folds of this type converge upward on the anticlines and downward on the synclines.

Recumbent folds that generally have maximum wavelengths and amplitudes of a few tens of feet occur on the crests or troughs and locally on the limbs of the open folds. They plunge subparallel to the major upright folds. A recumbent fold having a 500-foot amplitude, the largest known in the region, was mapped in the Chicago Creek area (Harrison and Wells, 1959).

The younger deformation, in contrast to the older, was dominantly cataclastic, and it was nearly restricted to the southeast part of the region. This younger deformation was intense in a 2-mile-wide zone that trends northeast through Idaho Springs (fig. 3). In this zone, many small folds were developed in the more incompetent rock units, especially the biotite gneisses and migmatite; locally intense granulation developed in the more competent units such as the microcline-quartzplagioclase-biotite gneiss.

The younger folds are small, commonly only a few feet or few tens of feet across; accordingly individual fold axes are not shown on figure 3 . They trend $\mathrm{N}$. $55^{\circ}$ E. and are superposed on the older folds; their form is controlled largely by their geometric relation to the attitude of the preexisting rock. The most common forms are terrace, chevron, and monoclinal folds; a less common fold is the round-crested, closed type. All the folds are asymmetric and have steep axial planes. Their asymmetry indicates the same relative motion, the northwest side having been raised relative to the southeast side.

Cataclasis is associated with and closely related to the folds, but it is most conspicuous and intense in massive, more competent units that did not fold during the younger deformation. Cataclasis was especially intense in the eastward-trending layer of microclinequartz-plagioclase-biotite gneiss, $11 / 2$ miles north of Idaho Springs (fig. 3). This layer is pervasively granulated, commonly to a flaser gneiss. Shear planes in the rock unit strike northeast and dip moderately northwest.

The character of the folds, rock textures and structures, and mineral assemblages of the reconstituted rocks indicate that the older fold system resulted from a plastic deformation at a considerable depth in the earth's crust, whereas the younger system resulted from deformation at probable shallower depths. Possibly the younger deformation was a deep manifestation of faulting (Moench, and others, 1954, p. 1383-1384; 1962, p. 54).

\section{FORM OF TERTIARY INTRUSIVE ROCKS}

The Tertiary intrusive rocks occur as small irregular plutons and as dikes (pl. 1). Commonly short dikes radiate outward from the plutons. The plutons range in size from a few hundred to a few thousand feet in longest dimension and appear to have steep walls. The dikes range in width from afew inches to a few hundred feet, but commonly are 5 to 50 feet wide; they range in length from a few hundred feet to several miles. Most dikes dip more steeply than $60^{\circ}$.

With few exceptions, the older intrusive bodies are irregular stocklike plutons whereas the younger ones are dikes.

The Tertiary igneous rocks were intruded along preexisting planes of weakness in the Precambrian rocks. Joints of various directions were the principal sites of emplacement, but faults, axial planes of folds, foliation planes, and contacts also provided favorable structures along which dikes were intruded.

\section{JOINTS}

Joints are a conspicuous feature of all the rocks in the region, and two or more sets can be measured in nearly every exposure. As might be expected from the long involved structural history of the Front Range, the joint pattern is complex and difficult to interpret. The principal joints seem to constitute a regional system that has a consistent relation to the gross structural pattern of the Front Range highland; other joints seem to be related to the fold system in the Precambrian rocks (Harrison and Moench, 1961).

The joint pattern in the central part of the Front Range mineral belt is grossly similar throughout, but individual joint sets are defined to varying degrees in the different mining districts and even within different parts of the same district. The principal joint sets in each of the mining districts, as indicated by statistical maxima, are given in table 7. Less well defined joint sets that are present within the districts are not discussed in this report. 
TAML: 7.-Principal joint sets in mining districts of the central part of the Front liange mineral belt

\begin{tabular}{|c|c|c|c|}
\hline Mining district or aren & $\begin{array}{l}\text { Number } \\
\text { of prin- } \\
\text { cipal joint } \\
\text { sets }\end{array}$ & Strike & Dip \\
\hline 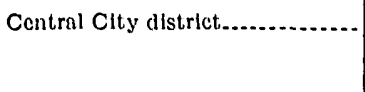 & 4 & $\begin{array}{l}\mathrm{N} .30^{\circ} \mathrm{W} \\
\mathrm{N}: 45^{\circ} \mathrm{W} \\
\mathrm{N} .76^{\circ} \mathrm{E} \\
\text { N. } 75^{\circ} \mathrm{W} \\
\mathrm{W}\end{array}$ & $\begin{array}{l}80^{\circ} \mathrm{NE} \\
80^{\circ} \mathrm{NE} \\
80^{\circ} \mathrm{N} . \\
80^{\circ} \mathrm{N}\end{array}$ \\
\hline 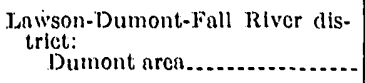 & 2 & N. $80-85^{\circ} \mathrm{E}$ & $70^{\circ}-73^{\circ} \mathrm{N}$ \\
\hline Lawson-Fall River area........ & 4 & $\begin{array}{l}\mathrm{N} .68^{\circ}-70^{\circ} \mathrm{W} \\
\mathrm{N} .80^{\circ} \mathrm{E} \\
\mathrm{N} .70^{\circ}-80^{\circ} \mathrm{WW} \\
\mathrm{N} \\
\mathrm{N}\end{array}$ & $\begin{array}{l}76^{\circ} \mathrm{NE} . \\
77^{\circ} \mathrm{N} . \\
80^{\circ} \mathrm{N} \\
80^{\circ} \mathrm{NE} \\
82^{\circ} \mathrm{NE}\end{array}$ \\
\hline Frecland-Lamartime district 1.... & 4 & $\begin{array}{l}\text { N. } 74^{\circ} \mathrm{W} \\
\text { N. } 82^{\circ} \mathrm{E} \\
\mathrm{N} .22^{\circ} \mathrm{W} \\
\mathrm{N} .\end{array}$ & $\begin{array}{l}68^{\circ} \mathrm{N} . \\
62^{\circ} \mathrm{N} . \\
79^{\circ} \mathrm{NE} . \\
63^{\circ} \mathrm{NW}\end{array}$ \\
\hline Chicngo Creck aren 2.......... & 3 & 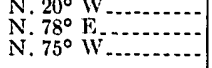 & $\begin{array}{l}90^{\circ} \mathrm{NW} \\
70^{\circ} \mathrm{NW} \\
73^{\circ} \mathrm{NE}\end{array}$ \\
\hline $\begin{array}{l}\text { Idnho Springs district: } \\
\text { Northwestern part s.... }\end{array}$ & 3 & 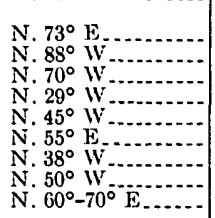 & $\begin{array}{l}75^{\circ}-85^{\circ} \mathrm{NW} . \\
70^{\circ}-80^{\circ} \mathrm{N} . \\
80^{\circ} \mathrm{NE} . \\
85^{\circ} \mathrm{NE} . \\
78^{\circ} \mathrm{NF} . \\
67^{\circ} \mathrm{NW} \\
85^{\circ}-90^{\circ} \mathrm{NE} . \\
80^{\circ} \mathrm{NE} . \\
70^{\circ}-80^{\circ} \mathrm{NW} .\end{array}$ \\
\hline
\end{tabular}

At least three joint sets are well defined throughout the region. Joints that strike $\mathrm{N} .70^{\circ}-80^{\circ} \mathrm{E}$. and $\mathrm{N}$. $70^{\circ}-75^{\circ} \mathrm{W}$. and dip steeply north are common to all mining districts; joints that strike N. $12^{\circ}-30^{\circ} \mathrm{W}$. and dip steeply northeast are abundant in most parts of the region. The other sets, although locally present, are not defined sufficiently on a regional scale to show up as prominent maxima on all statistical plots.

The three joint sets that are abundant throughout a large part of the region seem to constitute a regional joint system that is superimposed on all Precambrian rocks and is largely independent of older(?) joints. This joint system has been inferred to be Laramide in age (Harrison and Moench, 1961) because it is not appreciably affected by variations in the structure of the Precimbrian rocks and because it conforms to the pattern expected from the Laramide uplift of the Front Range highland.

If the regional joint system was developed during the uplift of the Front Range highland in the Laramide orogeny, it can be interpreted to be related to compressive stresses oriented east-northeast-west-southwest (Moench and Harrison, 1961).

\section{FAULTS}

Faults are abundant in the mining districts of the central part of the Front Range mineral belt (pl. 2). They are defined by the ore and gangue minerals they contain, by barren clay gouge, or by a wide zone of brecciated, silicified, and locally pyritized wallrock.
The faults clearly are of two ages. One group formed before early Tertiary (Laramide) igneous intrusion, and the other group formed near the close of the igneous activity, in Laramide time. Lovering and Goddard (1950, p. 79-82), in their comprehensive paper on the Front Range, assumed that fractures belonging to both groups developed during the Laramide revolution, although they recognized that some of them may follow zones of weakness that developed much earlier. New data obtained by the writers in the Front Range and adjacent parts of the Rocky Mountains, however, indicate that the older group of faults probably developed initially in Precambrian time. In this report the older faults are referred to, therefore, as Precambrian(?) faults. In an earlier report, Sims, Drake, and Tooker (1963) referred to this same group of faults as pre-Laramide(?) faults.

\section{CLASSIFICATION AND DESCRIPTION}

Detailed geologic mapping has established that the faults of this region can be grouped into six principal fracture sets, each characterized by consistent structural attitudes and common movement patterns. Five of the fracture sets are classified in this report according to trend, for they dip steeply and their trend (apparent strike) is nearly the same as their true strike. The sixth fracture set consists of low-angle faults that generally strike east or east-northeast. Because of their low dip, these faults have highly variable trends, depending upon the topography (pl. 2).

The older fracture sets, of presumed Precambrian age, include northwestward-trending, north-northeastward-trending, and low-angle faults. The younger fracture sets, of Laramide age, include eastward-, eastnortheastward-, and northeastward-trending faults.

Two minor fault sets that formed after ore deposition have been observed locally, but they are sparse and poorly exposed. These faults do not displace the ore bodies more than a few feet.

Except for some of the older northwestward-trending and northeastward-trending faults, the apparent offset along the faults rarely exceeds 20 feet and commonly does not exceed 5 or 10 feet. Accordingly, the displacement along these fractures commonly cannot be determined at the surface, but can be obtained only in underground workings. Along most faults it is evident from offset rock layers and slickensides that the dominant displacement was in a horizontal direction, but many fault surfaces also contain some steeply plunging slickensides, indicating some downdip movement. Most of the steeply plunging slickensides that have been observed are later than the horizontal(?) slickensides, and these may partly represent small read- 


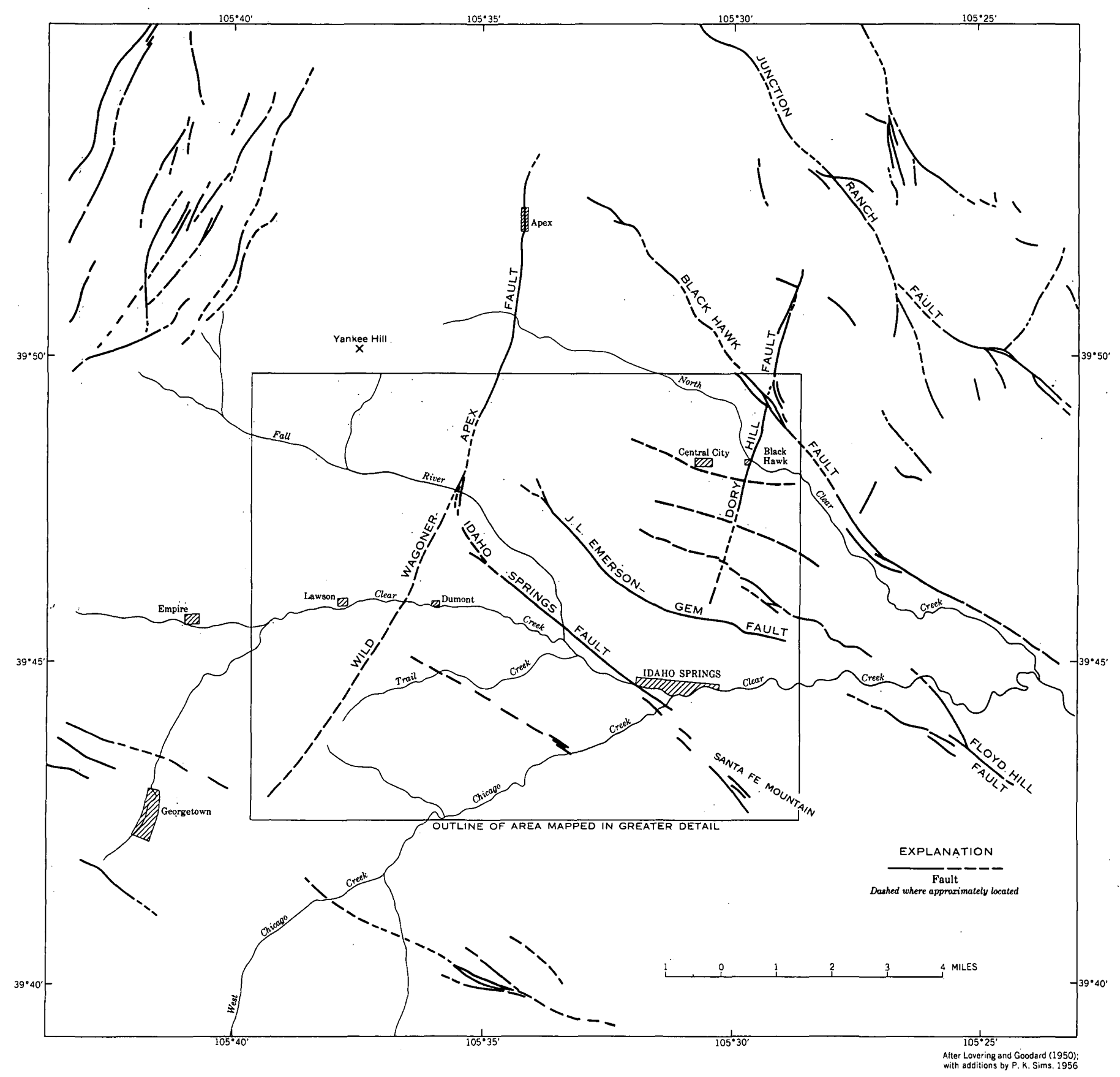

FIGURE 6.-Map showing principal Precambrian([) faults, within and adjacent to the central part of the Front Range mineral belt.

justments that took place after the dominant slip movements.

In the following discussion right lateral (or right hand) and left lateral (or left hand) refer to the apparent movement of the two blocks as seen in a map view; right lateral indicates clockwise separation of the opposite block, relative to that of the observer, and left lateral indicates counterclockwise separation, as described by Hill (1947).
FAULTS OF PRECAMBRTAN (?) AGE

The principal older faults, the northwestward-trending and the north-northeastward-trending sets, are widely spaced long continuous fractures or fracture zones that can be traced for several miles. To show the broad relations between the principal faults in the mapped area (pl. 2) and those in adjacent areas, figure 6 was compiled from existing data. Less persistent faults of these two fracture sets within the mapped 
area are shown on plate 2 , but not on figure 6 . Because the low-ange faults are not long persistent fractures, they are not shown on figure 6 .

In this part of the Front Range (fig. 6), several prominent northwestward-trending faults, spaced 1 to 6 miles apart, cross the mineral belt. These faults constitute the fracture system that Lovering (Lovering and Tweto, 1953, p. 30; Lovering and Goddard, 1950, pls. 1 and 3 ) has described as "breccia reefs" or "breccia dikes." Within the central part of the mineral belt, many of the northwestward-trending faults resemble typical breccia reefs because they form conspicuous topographic ridges along their outcrop, but many more differ from the typical reefs in being inconspicuous and difficult to trace at the surface. In this area the northwestward-trending faults are left-lateral faults, and the apparent horizontal displacement along the faults is as much as 600 feet. So far as known the vertical component of movement is considerably less than the horizontal component.

The low-angle faults occur between northwestwardtrending faults and are related genetically to them; a few extend from one fault to the next adjacent one (pl. $2)$. Where observed, the apparent horizontal movement on these faults is left lateral, but the measured displacement is at most only a few feet.

The north-northeastward-trending faults locally form conspicuous siliceous reefs, but more commonly they are gouge filled and inconspicuous. In contrast to the northwestward-trending faults, these fractures are remarkably straight. The displacement along these faults is right lateral. The apparent horizontal displacement along the Wild Wagoner-Apex fault is as much as 600 feet.

Judging from the intersection of the Dory Hill and Blackhawk faults, the north-northeastward-trending faults are younger than the northwestward-trending faults. Although the Dory Hill fault is shifted laterally a few tens of feet along individual strands of the Blackhawk fault (pls. 1, 2), the Precambrian rocks are offset about 500 feet on opposite sides of the Blackhawk fault. This indicates, therefore, that the major movement along the Blackhawk fault was before the formation of the Dory Hill fault, and that the horizontal displacement of the Dory Hill fault resulted from later movements.

Northwestward-trending faults.-The northwestward-trending fracture set consists of 3 prominent continuous faults and 4 less persistent northwestwardtrending zones of fracturing (pl. 2). The northwestward-trending faults strike N. $40^{\circ}-85^{\circ} \mathrm{W}$. and $\operatorname{dip} 50^{\circ}$ to $90^{\circ} \mathrm{NW}$., with steep dips being most common. The northwestward-striking segments of the faults com- monly are more silicified within the mapped area (pl. 2) than the west-northwestward-striking segments, and they can be more easily traced.

The Blackhawk, J. L. Emerson-Gem, and Idaho Springs faults are long continuous fracture zones. The Blackhawk fault consists of several subparallel faults and many connecting fractures that constitute a fault zone about 2,000 feet wide. The fault displaces the Precambrian rock units about 500 feet, but displaces a dike of Tertiary quartz monzonite porphyry only 100 feet in the same direction (left lateral). The Idaho Springs fault is a much narrower straight fault that shows a 600 -foot left-lateral displacement of the Precambrian rocks on opposite walls. It is followed along much of its course by one or more dikes of quartz monzonite porphyry. The J. L. Emerson-Gem fault has a flat $\mathbf{S}$ shape in the map view, ranging in strike from about $\mathrm{N} .40^{\circ} \mathrm{W}$. to about $\mathrm{N} .80^{\circ} \mathrm{W}$. It consists of several closely spaced, overlapping fissures which constitute a fracture zone several tens of feet wide, but in contrast to the Blackhawk and Idaho Springs faults it does not appreciably displace its walls. It can be seen in several mines that the movement on individual faults was left lateral, but the apparent horizontal displacements are at most a few feet.

Three inconspicuous northwestward-trending zones of fracturing occur in the Central City district between the Blackhawk fault and the J. L. Emerson-Gem fault, and a fourth zone of fracturing is about 2 miles southwest of, and subparallel to, the Idaho Springs fault. These zones are designated on plate 2, from northeast to southwest, as the Eureka Gulch, Illinois Gulch, Russell Gulch, and Cottonwood Gulch fault zones. The fault zones at Central City probably represent splits from the Floyd Hill fault (fig. 6), a prominent fault on Floyd Hill, 5 miles east of Idaho Springs. The Cottonwood Gulch fault zone locally contains Tertiary dikes east of Chicago Creek; possibly it is a split from the Idaho Springs fault. Locally segments of each of the faults contain sulfide ore minerals.

Low-angle faults.-Faults that dip less than $50^{\circ}$ are abundant between the J. L. Emerson-Gem fault system and the Idaho Springs fault, and between the Idaho Springs fault and the Cottonwood Gulch fault zone (pl. 2). Two such faults occur between the J. L. Emerson-Gem fault system and the Russell Gulch fault zone, and at least.one is present southwest of the Cottonwood Gulch fault zone. This group of faults strikes east- to east-northeast and $\operatorname{dips} 20^{\circ}-50^{\circ} \mathrm{N}$. Many of the faults cut across the foliation of the country rock, but in certain areas, as south of Idaho Springs, several faults are subparallel to the foliation. All faults of this group 
that have been recognized contain sulfide ore minerals at least locally.

North-northeastward-trending faults.-Two main north-northeastward-trending faults, the Dory Hill fault at Central City and the Wild Wagoner-Apex fault in the Lawson-Dumont-Fall River district, occur in the region (fig. 6); several discontinuous faults of the same trend are between the two faults (pl. 2). The main faults are characteristically several tens of feet wide, long and continuous, and locally contain siliceous breccias similar to the typical breccia reefs. They dip more steeply than $60^{\circ}$. The Dory Hill fault has been traced for a distance of 4 miles (fig. 6), and it is inferred to extend southward to the vicinity of Idaho Springs. The Wild Wagoner-Apex fault was followed previously from Apex southward to Fall River (Lovering and Goddard, 1950, pl. 2), and we have found that it extends another 6 miles to the south (fig. 6 ). Several discontinuous north-northeastward-trending faults, most of which contain sulfide veins, occur between the Dory Hill and Wild Wagoner-Apex fault. The most notable faults of this group constitute north-northeastwardtrending segments of the Lamartine-Great Western and Lone Tree vein systems in the Freeland-Lamartine district (Harrison, 1955, p. 314), and the Fairfield and Mineral veins at Central City.

\section{FAULTS OF LARAMIDE AGE}

The Laramide faults are more abundant and more closely spaced than the older faults, and they commonly form an intersecting network. They cut and displace all the early Tertiary porphyritic igneous rocks except biotite-quartz latite porphyry.

Eastward-trending faults.-The eastward-trending faults are common in the Central City district but sparse in other parts of the region. Although they strike generally eastward, individual faults vary as much as $10^{\circ}$ from east. They dip $80^{\circ}$ or more, either to the north or south and many hinge along the dip. The movement on the faults is dominantly strike slip, the north wall having moved west relative to the south wall. The apparent horizontal displacement indicated by displaced porphyry dikes is small and does not exceed 20 feet. In the Central City district the faults of this attitude commonly are wider than most vein fissures, commonly form lodes, and contain many valuable ore bodies. In most other districts, faults of this attitude are generally thin and poorly mineralized or barren.

East-northeastward-trending faults.-East-northeastward-trending faults are present in all mining districts in the region, but they are neither abundant nor economically important in the Chicago Creek and Freeland-Lamartine districts. In the Central City,
Lawson-Dumont-Fall River, and Idaho Springs districts they contain many valuable veins. The faults of this set strike N. $60^{\circ}-80^{\circ}$ E. and commonly dip $70^{\circ}$ or more northwest or southeast. Northwest dips predominate in the Idaho Springs and Chicago Creek districts; opposing dips of adjacent subparallel veins are common in parts of the Central City district. Movement along the faults was dominantly. right lateral, the northwest walls having moved northeast relative to the southeast walls. The apparent horizontal displacement rarely exceeds 10 feet. At places the faults developed parallel to foliation surfaces or to axial planes of tight folds.

Northeastward-trending faults.-Northeastwardtrending faults that strike $\mathrm{N} .40^{\circ}-55^{\circ} \mathrm{E}$. and dip steeply are abundant in the Chicago Creek, Idaho Springs, and part of the Central City districts (pl. 2). They contain several valuable veins, particularly in the Idaho Springs district. Many of these faults are remarkably consistent in strike. Displacements along the faults are small, rarely exceeding 15 feet; most faults have a right-lateral movement, the northwest block having moved northeast relative to the southwest block. The zones of fracturing commonly do not exceed 2 feet in width; the walls tend to be smooth and even; and gouge is neither abundant nor widespread.

\section{FAULT PATTERN}

The pattern resulting from the fracturing is principally a complex meshlike network of several sets of intersecting faults, but locally it shows long cymoid ${ }^{1}$ fissures formed by the combination of fractures of two or more different sets (pls. 1,2). Intersecting faults are common at Central City and in the northern part of the Idaho Springs district, where all fault sets are well formed. The early northwestward-trending and associated relatively flat-dipping fractures are cut but not noticeably displaced by the later eastward-, eastnortheastward-, and northeastward-trending fractures to produce a complex intersecting pattern. Where the faults strike at acute angles to one another, they may junction to form local $Y$-shaped patterns. The formation of cymoid fissures by the combination of fractures has been described in the Freeland-Lamartine district by Harrison (1955). Two of the cymoid fissures in the Freeland-Lamartine district are inferred to have a central segment belonging to the north-northeast fracture set and ends belonging to the east-northeast and east sets; they were formed by the combination of Precambrian(?) fractures and Laramide fractures.

${ }^{1}$ A cymold curve is a reverse curve in which a line swerves from its course and then swings back again, resuming a direction parallel to its former course but not in line with it (McKinstry, 1948, p. 315). 
The third cymoid fissure probably has a central segment belonging to the flat-dipping fracture set and ends belonging to the east-northeast and east sets; it also was formed by the combination of fractures of different ages.

\section{AGE AND ORIGIN OF FAULTS}

The two groups of faults of different ages that constitute the fracture system of the region contrast sharply in general character and continuity and apparently formed from different stress patterns. The older fault sets are persistent widely spaced fractures or zones of fractures; several of the northwestward-trending faults can be traced for several miles outside of the mineral belt (Lovering and Goddard, 1950, pl. 1). These fractures must have developed from regional stresses that affected most or all of the Front Range highland. The nature of these forces is not yet known, however, and much more work throughout the Front Range is needed for their intrepretation. The younger faults, on the other hand, are relatively discontinuous, closely spaced, intersecting fractures that seem to be neirly restricted to the mineral belt. These faults probably formed from regional (horizontal?) compressive forces acting in a general east-northeastward direction.

The first faults to form in the region were the northwestward-trending breccia reefs and related faults. As pointed out by Lovering and Goddard (1950, p. 79-80) the relative movement along different fractures of this set varied in the Front Range. Within the central part of the mineral belt the fault movements were consistent however, the northeast walls having moved northwest with respect to the southwest walls.

The north-northeastward-trending faults formed later than the northwestward-trending faults, but how much later is not known. Like the northwestwardtrending faults, this set of fractures is widely distributed in the Front Range, but according to Lovering and Goddard (1950, p. 79 and pl. 3), the faults are most abundant near the crest and on the east side of the range. The fault set is nearly perpendicular to the northwestward-trending set, and it is diagonal to the axis of the range. The faults characteristically have right-lateral movements.

The northwestward-trending and north-northeastward-trending fault sets could have formed at any time between late Precambrian and Laramide time, but the field data indicate that they probably originated in the Precambrian. Faults belonging to the northwestwardtrending set, its genetically related low-angle faults, and the north-northeastward-trending set locally are followed, or cut, by the early Tertiary porphyritic ig- neous rocks, indicating their existence prior to emplacement of the igneous rocks. The oldest intrusive rock that occurs along these fracture sets is quartz-monzonite porphyry (see fig. 4). Further, some of the faults displace the Precambrian rocks on opposite walls considerably more than bodies of the Tertiary igneous rocks, indicating movement along these fractures prior to intrusion of these igneous rocks. The best evidence of a Precambrian age for the northwestward-trending fracture set has been set forth by Vitanage (1954) in the South Platte area, about 3 miles south of Idaho Springs. In this area, northwestward-trending faults, in all respects similar to those in the mineral belt, contain sandstone dikes that are interpreted to have been formed by injection of clastic material along submarine faults in Cambrian time. The sandstone is identical to that in the Cambrian Sawatch formation. The nearest exposures of the Sawatch formation are about 10 miles southeast of the main dike in the South Platte area. Later geologic mapping by G. R. Scott and Warren Peterson (oral communication, 1959) of the Geological Survey, in the same area confirm the conclusions of Vitanage that the northwestward-trending fault set originated in Precambrian time. The north-northeastward-trending faults are interpreted also as probably being Precambrian in age because of their gross similarity to the northwest fracture set. Like the northwestward-trending faults, they are long, persistent wide fractures or fracture zones that record several periods of movement, and they locally contain siliceous breccias, indicating an early period of mineralization.

The Laramide fault system developed after the emplacement of quartz bostonite porphyry and before the intrusion of biotite-quartz latite porphyry. As the eastward-trending set generally is characterized by leftlateral displacement, and the east-northeastward- and northeastward-trending sets are characterized by rightlateral displacements, the fracture sets can be interpreted to represent conjugate shear fractures resulting from a horizontal(?) compressive force oriented eastnortheast, the eastward-trending set constituting one of the diagonals and the other two sets (east-northeast and northeast) constituting the other. The faults can also be interpreted to have resulted from rotational compressive stresses oriented northeastward, as originally proposed by Lovering and Goddard (1950, p. 80-82). At the time these faults were formed, westward-striking parts of the earlier northwest fault set were reopened to provide sites for ore deposition, and as a result, segments of all the faults of this set except the Blackhawk were locally mineralized.

The three sets of Laramicle faults developed virtually contemporaneously, as might be expected of conjugate 
shear faults. At most places in the region they formed in the following order: eastward-, east-northeastward-, and northeastward-trending faults. Locally, however, the east-northeastward-trending fractures developed before the eastward-trending fractures, as in the Freeland-Lamartine district (Harrison, 1955, p. 313-316; Harrison and Wells, 1956, p. 67-70) and the Chicago Creek district (Harrison and Wells, 1959). This variation in the sequence of development of the fractures probably can be explained by differences in the structural fabric of the country rock. In those areas where the fractures formed in the sequence, eastward-, eastnortheastward-, and northeastward-trending faults, the country rock is characterized by more open folds, and accordingly the dip of both the rock units and the foliation is moderate; further, most of this area is underlain by relatively massive microcline-quartz-plagioclasebiotite gneiss. The bedrock of this area, therefore, must have acted as a relatively homogeneous mass to the deforming stresses. The first breaks to form were in an east-west direction, possibly along the east-west joint set that is prominent in these rocks and which may have been the weakest fabric direction. In the FreelandLamartine and Chicago Creek districts, on the other hand, the bedrock at most places is characterized by northeastward-trending, tight folds, which produce a marked northeastward-oriented fabric. This fabric orientation may have provided structural weaknesses that were greater than in any other fabric direction, and as a result the northeastward-trending fractures developed first in the sequence.

The faults of both fracture systems were reopened intermittently, as shown by fracturing, brecciation, and recementation of the vein filling formed during mineralization. Fracturing and brecciation separated the stages of mineralization, and at most places it appears that the fracturing separating each stage was essentially synchronous throughout the region (Sims, 1956a): At some places, however, particularly in the FreelandLamartine (Harrison, 1955) and Chicago Creek (Harrison and Wells, 1959) districts, some fracturing may have taken place in a time sequence during mineralization; the fractures were filled with ore minerals as they formed.

\section{SUMMARY OF GEOLOGIC HISTORY}

The central part of the Front Range mineral belt has had a long complex geologic history. The record is incomplete, however, and many events cannot be precisely dated.

The first datable geologic event in the region was the plastic deformation that produced the northeastwardtrending folds which define the gross distribution of the rock units. During the deformation the oldest rocks, an interlayered sequence, were folded into open upright anticlines and synclines and tight upright to overturned folds and were intruded by igneous bodies of various sizes. Probably the oldest rocks were dominantly sediments that recrystallized mimetically before they were folded. During the folding these rocks were reconstituted to mineral assemblages which were stable in the upper part of the amphibolite metamorphic facies. Migmatite and granite gneiss and pegmatite were formed during the early stages of the folding, either by injection, metamorphic differentiation, or transformation. As deformation continued, granodiorite, and slightly later, quartz diorite and hornblendite intruded the now high-grade metamorphic rocks as generally conformable plutons of various sizes. The stresses accompanying the deformation continued after the consolidation of these bodies, deforming these rocks, particularly along their contacts. Later pulsations of the stresses, near the end of the period of deformation, were accompanied by the intrusion of biotite-muscovite granite, partly as phacoliths. The local crosscutting relations of this granite, however, indicate that it was partly emplaced after the period of maximum deformation. Following this sequence of events the region was uplifted and several thousand (?) feet of rock were removed. Late in the Precambrian the region again was deformed. This deformation, in contrast to the earlier one, was local. It was intense in a 2 -milewide zone trending northeast along the southeast margin of the mineral belt. In this area, the less competent schistose rocks were folded locally and the more competent massive rocks were granulated to different degrees. Probably late in the Precambrian, first northwestwardtrending then north-northeastward-trending faults were formed. These faults were continuous fractures, commonly several miles long.

It is known from studies elsewhere that the Front Range was uplifted in Pennsylvanian time, but evidence of this uplift has not been recognized in the core of the range because of the absence of Paleozoic sedimentary rocks.

Uplift of the Front Range began again in Late Cretaceous time. The highland was arched along a northnorthwestward-trending axis, and some faults may have formed. Possibly at this time a regional joint system developed, presumably from east-northeastwardoriented stresses that were related to the uplift. Following this event, in early Tertiary time, porphyry dikes and irregular plutons were intruded along structural weaknesses in the bedrock. Preexisting joints, faults, and locally other planar features were opened, presumably by tensional stresses, to allow the hyp- 
abyssal igneous rocks to enter without noticeably forcing their walls apart. The tensional openings may have resulted from arching of the highland, but they may well have resulted from a more local uplift that was confined principally to the mineral belt. The older intrusive rocks apparently were emplaced at greater depths in the crust than the younger intrusive rocks, for the former: have textures indicative of slower cooling and chill borders are absent. The older intrusive rocks formed irregular small stocks and rarely dikes; the younger intrusive rocks formed dikes, many of which are remarkably continuous. Near the close of the hypabyssal igneous activity, abundant eastward-, eastnortheast ward-and northeastward-trending faults were formed; the eastward-trending parts of the earlier northwestward-trending fractures were reopened, possibly as the result of horizontal(?) stresses oriented east-northeast; and the fractures were mineralized to form gold-, silver-, and uranium-bearing sulfide veins. Later faulting produced fractures that locally cut the mineralized veins.

The 'Tertiary history of the Front Range is little known, but late in the period canyon cutting was started and eventually formed the present highly dissected mountainous terrane.

Quaternary time is represented in the higher parts of the region by solifluction debris and talus, probably of Wisconsin age, and throughout by alluvium, probably of both Pleistocene and Recent age.

\section{ORE DEPOSITS}

The ore deposits of the region are sulfide-quartz veins, zonally distributed around a major center of mineralization, which contain precious metals, base metals, and uranium, and which are chiefly valuable for their gold and silver content. The uranium-bearing deposits are described separately in a later section.

The veins are hydrothermal fillings in fault fissures and are similar in mineralogy, texture, and structure to the deposits classified by Lindgren (1933, p. 530) as mesothermal. Aside from a few that contain only pyrite and gangue, the veins in all parts of the region contain the same suite of major ore minerals. The principal ore minerals are sulfides and sulfosalts of iron, copper, lead, zinc, and silver. Ore minerals that are less abundant but common are native gold, pitchblende, and gold tellurides. The gangue minerals include, in order of decreasing abundance, several varieties of quartz, carbonate minerals of the calcite group; barite, and fluorite.

Although vein filling took place during a single period of mineralization, the ore minerals were deposited in at least two distinct stages : the dominant sulfide-stage mineralization began with the deposition of pyrite and quartz; this phase was followed by the deposition of base-metal sulfide and gangue minerals. Locally, uranium was deposited during an early (third) stage that preceded the sulfide ore mineralization. Major periods of vein reopening that seem to have been synchronous over the region occurred between the stages of mineralization, and more restricted fracturing took place during the stages of filling.

\section{STRUCTURE AND GENERAL CHARACTER}

The veins vary from single well-defined filled fissures to complexly branching lodes consisting of subparallel fractures, loops, and horsetailing fractures. The simplest veins consist of a single filled fissure, commonly with smooth sharp walls, that is bounded by a narrow persistent zone of altered wallrock. Commonly, however, subsidiary veins branch or split from the main veins, and the complexity of the branching increases as true lodes are developed. Breccia, gouge, and slickensides are common, particularly in certain veins. Vugs occur in all veins, but they are neither abundant nor large. Lodes consisting of two or more closely spaced subparallel veins are more complex than the single vein fissures. The wallrock horses between the separate veins are altered, fractured, moderately to strongly pyritized, and locally cut by 1 -inch-thick stringers of ore minerals which may be sufficiently abundant and closely spaced to constitute ore. In some veins breccia fragments are surrounded by a cockade growth of gangue and ore minerals.

The veins in the district range in width from less than 1 inch to a few tens of feet, but average 1 to 2 feet. Single veins vary considerably in width, the ore shoots commonly being two or more times wider than the virtually barren parts of the veins.

The ore shoots occur in structurally controlled open spaces along the vein fissures and generally constitute a small proportion of the explored ground. They can be related to several structural factors, the most important being the direction and amount of fault movement, the physical character and structure of the wallrock, and irregularities along the fissures themselves. The relative importance of these factors in the localization of ore bodies in the Front Range mineral belt has been discussed by Lovering (1942, p. 79-93) ; details within the districts of the region are given in the different reports prepared during the current investigation (Harrison and Wells, 1956, 1959; Drake, 1957; Sims, Drake, and Tooker, 1963).

\section{MINERALOGY}

The veins contain a simple suite of ore and gangue minerals, but the proportions of the minerals vary greatly both within and between individual districts. 
The common primary metallic minerals are pyrite, sphalerite, galena, chalcopyrite, and tetrahedrite-tennantite. Other locally abundant minerals are enargite, marcasite, polybasite, pearceite, tellurides of gold and silver, and free gold or electrum. The common secondary ore minerals are chalcocite, covellite, and hydrous iron oxides. The gangue minerals are dominantly forms of silica and carbonates of the calcite group but are locally fluorite or barite.

A list of the minerals known or reported to be present in the mining districts of the region, exclusive of uranium minerals which are listed and described later in this report, is given in table 8 .

TABLE 8.-Primary and secondary vein minerals, exclusive of uranium minerals

\begin{tabular}{|c|c|}
\hline Primary & Secondary \\
\hline \multicolumn{2}{|c|}{ Sulfides } \\
\hline $\begin{array}{l}\text { Pyrite, } \mathrm{FeS}_{2} \\
\text { Sphalerite, } \mathrm{ZnS} \\
\text { Galena, PbS } \\
\text { Chalcopyrite, } \mathrm{CuFeS}_{2} \\
\text { Marcasite, } \mathrm{FeS}_{2} \\
\text { Molybdenite, } \mathrm{MoS}_{2} \\
\text { Argentite(?), } \mathrm{Ag}_{2} \mathrm{~S} \\
\text { Bornite, } \mathrm{Cu}_{5} \mathrm{FeS}_{4}\end{array}$ & $\begin{array}{l}\text { Chalcocite, } \mathrm{Cu}_{2} \mathrm{~S} \\
\text { Covellite, } \mathrm{CuS} \\
\text { Argentite, } \mathrm{Ag}_{2} \mathrm{~S} \\
\text { Sphalerite(?), } \mathrm{ZnS}\end{array}$ \\
\hline
\end{tabular}

\begin{tabular}{|c|c|}
\hline $\begin{array}{l}\text { Tennantite, }(\mathrm{Cu}, \mathrm{Fe}, \mathrm{Zn}, \mathrm{Ag})_{12} \mathrm{As}_{4} \mathrm{~S}_{13} \\
\text { Tetrahedrite, }(\mathrm{Cu}, \mathrm{Fe}, \mathrm{Zn}, \mathrm{Ag})_{12} \mathrm{Sb}_{4} \mathrm{~S}_{13} \\
\text { Enargite, } \mathrm{Cu}_{3} \mathrm{AsS} \\
\text { Pearceite, }(\mathrm{Ag}, \mathrm{Cu})_{16} \mathrm{As}_{2} \mathrm{~S}_{11} \\
\text { Chalcostibite }(?), \mathrm{Cu}_{2} \mathrm{~S} \mathrm{Sb}_{2} \mathrm{~S}_{3} \\
\text { Bournonite, } \mathrm{PbCuSbS}{ }_{3} \\
\text { Freibergite, }\left(\mathrm{Cu}, \mathrm{Fe}, \mathrm{Zn}_{3}, \mathrm{Ag}_{12} \mathrm{Sb}_{4} \mathrm{~S}_{13}\right. \\
\text { Polybasite, }(\mathrm{Ag}, \mathrm{Cu})_{16} \mathrm{Sb}_{2} \mathrm{~S}_{11}\end{array}$ & $\begin{array}{l}\text { Ruby silver, } \mathrm{Ag}_{3} \text { (As, } \\
\mathrm{Sb} \mathrm{S}_{3}\end{array}$ \\
\hline
\end{tabular}

\begin{tabular}{|c|c|}
\hline \multicolumn{2}{|c|}{ Native elements } \\
\hline $\begin{array}{l}\text { Gold, } \mathrm{Au} \\
\text { Electrum, } \mathrm{Ag} \cdot \mathrm{Au} \\
\text { Bismuth, } \mathrm{Bi}\end{array}$ & $\begin{array}{l}\text { Gold, Au } \\
\text { Silver, Ag }\end{array}$ \\
\hline \multicolumn{2}{|c|}{ Oxides } \\
\hline Hematite, $\mathrm{Fe}_{2} \mathrm{O}_{3}$ & Hydrous iron oxides \\
\hline \multicolumn{2}{|c|}{ Tungstates } \\
\hline \multicolumn{2}{|l|}{ Wolframite, $(\mathrm{Fe}, \mathrm{Mn}) \mathrm{WO}_{4}$} \\
\hline \multicolumn{2}{|c|}{ Tellurides } \\
\hline $\begin{array}{l}\text { Petzite, }\left(\mathrm{Ag}_{3} \mathrm{Au}\right)_{2} \mathrm{Te}_{2}\left(\mathrm{Ag}_{3} \mathrm{Au}\right) \mathrm{Te}_{2} \\
\text { Sylvanite, }(\mathrm{Ag}, \mathrm{Au}) \mathrm{Te}_{2} \\
\text { Calaverite, } \mathrm{AuTe} \\
\text { Altaite, PbTe } \\
\text { Coloradoite, } \mathrm{HgTe} \\
\text { Krennerite, (Au, Ag) } \mathrm{Te}_{2}\end{array}$ & \\
\hline
\end{tabular}

TABLE 8.-Primary and secondary vein minerals, exclusive of uranium minerals-Continued

\begin{tabular}{ll|l}
\hline \multicolumn{1}{c|}{ Primary } & Secondary \\
\hline \multicolumn{3}{c}{ Halides } \\
\hline Fluorite, $\mathrm{CaF}_{2}$ & Cerargyrite, $\mathrm{AgCl}$ \\
\hline & & \\
\hline
\end{tabular}

Wulfenite, $\mathrm{PbMoO}$

Arsenides

Niccolite, NiAs

Pararammelsbergite, $\mathrm{NiAs}_{2}$

\begin{tabular}{l|l}
\hline \multicolumn{2}{c|}{ Silicates } \\
\hline $\begin{array}{l}\text { Quartz, } \mathrm{SiO}_{2} \\
\text { Cryptocrystalline silica }\end{array}$ & $\begin{array}{l}\text { Quartz, } \mathrm{SiO}_{2} \\
\text { Cryptocrystalline sil- } \\
\text { ica(?) } \\
\text { Opal, } \mathrm{SiO}_{2} \cdot \mathrm{nH}_{2} \mathrm{O}\end{array}$ \\
\hline
\end{tabular}

\begin{tabular}{|c|c|}
\hline \multicolumn{2}{|c|}{ Carbonates } \\
\hline $\begin{array}{l}\text { Ankerite, } \mathrm{Ca}(\mathrm{Mg}, \mathrm{Mn}, \mathrm{Fe})\left(\mathrm{CO}_{3}\right)_{2} \\
\text { Siderite, }(\mathrm{Fe}, \mathrm{Mg}, \mathrm{Mn}) \mathrm{CO} \mathrm{O}_{3} \\
\text { Rhodochrosite, } \mathrm{MnCO}{ }_{3} \\
\text { Dolomite, } \mathrm{Ca}(\mathrm{Mg}, \mathrm{Fe}, \mathrm{Mn})\left(\mathrm{CO}_{3}\right)_{2}\end{array}$ & $\begin{array}{l}\text { Cerussite, } \mathrm{PbCO}_{3} \\
\text { Smithsonite, } \mathrm{ZnCO}_{3} \\
\text { Malachite, } \\
\mathrm{Cu}_{2}(\mathrm{OH})_{2} \mathrm{CO}_{3} \\
\text { Azurite, } \mathrm{Cu}_{3}(\mathrm{OH})_{2}\left(\mathrm{CO}_{3}\right)\end{array}$ \\
\hline \multicolumn{2}{|c|}{ Sulfates } \\
\hline Barite, $\mathrm{BaSO}_{4}$ & $\begin{array}{l}\text { Anglesite, } \mathrm{PbSO}_{4} \\
\text { Chalcanthite, } \\
\text { CuSO } \cdot 5 \mathrm{H}_{2} \mathrm{O} \\
\text { Epsomite }(?), \\
\mathrm{MgSO}_{4} \cdot 7 \mathrm{H}_{2} \mathrm{O}\end{array}$ \\
\hline
\end{tabular}

\section{CLASSIFICATION OF VEINS}

The veins contain different quantities of the primary vein-forming minerals and they can be classified into two distinct mineralogic types. One principal type, pyrite veins, contains abundant pyrite and varying amounts of base-metal sulfides and gangue, and predominantly constitutes gold ores; the other principal type, galena-sphalerite veins, contains abundant galena and sphalerite, sparse pyrite, and gangue, and constitutes silver-bearing lead-zinc ores. Transitional veins contain the minerals characteristic of the two main types as well as substantial quantities of copper minerals. The distribution of the veins of the different classes is shown on plate 1 . Those veins for which mineralogic data are lacking are listed on plate 1 as "type unknown." Veins of each class locally contain uranium and gold tellurides and these veins are shown on plate 1 by special symbols.

Several types of information have been used to classify the veins: (1) mineralogy as determined from 
examination of mine workings and dumps; (2) assays of veins and ore shipments; (3) production figures, and (4) silver-gold ratios. All these data are available for many veins in the district, some are available for others, and none are available for still other veins. For detailed information concerning the veins, the reader is referred to the reports on the separate mining districts.

The existence of veins containing the two contrasting types of ores was recognized moderately early in the development of the region. Near the turn of the century Collins (1903) described gold veins and silver veins at Central City and noted their areal distribution. Later Spurr and others (1908, p. 99-101) distinguished two types of veins in the Georgetown quadrangle: silverbearing veins without important amounts of gold (galena-blende ores) and gold-bearing veins with or without silver (pyritic ores). They also noted that both types of ore locally occurred together, and they referred to the mixture of the two types of ore as "compound ores." Bastin and Hill (1917, p. 105-114) recognized similar vein types in the Central City quadrangle, and they classified the ores into three main types: pyrite ores, galena-sphalerite ores, and composite ores. Their term "composite ores" is essentially equivalent to Spurr and others' term "compound ores," and includes pyritic galena-sphalerite ores which are mineralogically transitional between the two main types. Bastin and Fill (1917, p. 113) described the "composite ore" as consisting of pyritic ore sharply cut by veinlets of galena-sphalerite ore. They also recognized another important type, telluride ores. In their compilation of data on the Front Range, Lovering and Goddard (1950, p. 173) adopted the earlier classification of Bastin and Hill and added a new type, uranium ore.

The classification used in this report differs in some important aspects from that used by previous investigators. The classification is based on quantitative mineralogy. Pyrite and galena-sphalerite, the principal mineralogic variants in the veins, constitute the two principal vein types. The pyrite veins locally contain two distinct assemblages of base-metal sulfides and sulfosalts, one consisting dominantly of copper minerals and the other consisting of intergrown sphalerite, galena, and lesser amounts of copper minerals, therefore these veins are further subdivided into types. The pyrite veins that are nearly devoid of base-metal sulfides are type $A$ pyrite veins; those that contain substantial amounts of copper minerals are type $B$ pyrite veins; and those that contain sphalerite, galena, and copper minerals are type $C$ pyrite veins. The approximate quantities of the dominant metallic vein minerals in each type of vein are shown diagrammatically in

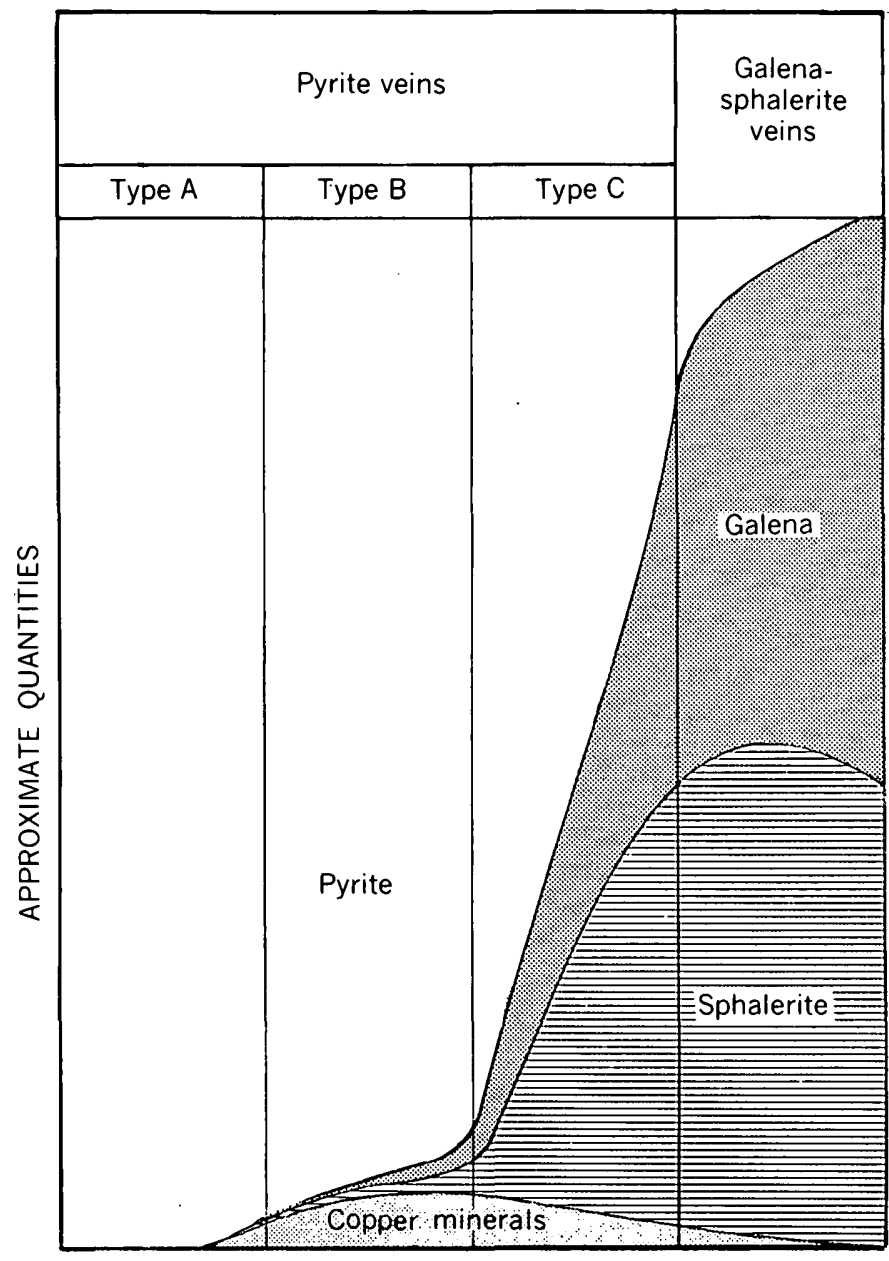

Figure 7.-Diagram showing the approximate quantities of the principal metallic vein minerals in pyrite and galena-sphalerite veins.

figure 7. Although each type of vein has a distinctive mineralogy, the types grade into one another through gradual changes in the proportions of metallic minerals and the quantitative limits defining each class are necessarily somewhat arbitrary.

The vein classification is based on the mineralogy and metal content of an entire vein or a large segment of a vein and not merely on the ore shoots. A pyrite vein of type $C$, for example, contains local ore shoots or smaller pods, lenses, or stringers of base-metal sulfides in a predominantly pyrite-quartz vein. The base-metal sulfides occur in stringers or other vein forms that cut the pyrite-quartz vein material, or more rarely as encrustations on pryite-quartz vein material. The vein is characterized by ores that contain base-metal sulfides and accompanying gold and silver. The vein material between ore shoots consists mainly of quartz and pyrite and commonly contains small quantities of base-metal sulfides. A galena-sphalerite vein, however, contains similar bodies of base-metal sulfide minerals, 
but copper minerals and gold are sparse, and the vein contains much smaller amounts of pyrite. Between ore shoots the veins commonly consist largely of gouge with only sparse pyrite, which contrasts with the pyrite veins of type $C$.

The pyrite veins of type $A$ consists dominantly of pyrite and quartz witht traces of chalcopyrite, tetrahedrite-tennantite, sphalerite, and galena. Some of the pyrite contains gold. The silver-gold ratio in this type of vein is less than $5: 1$ and commonly is about $1: 1$. In general, few veins of this type contain sufficient gold to be profitably mined.

Pyrite veins of type $B$ contain substantial copper, generally as chalcopyrite or as tetrahedrite-tennantite but locally as enargite, as well as abundant pyrite and quartz. Sphalerite is more abundant than in type $A$ pyrite veins but is not common; galena is rare. Carbonate minerals are absent except locally in the Idaho Springs and Chicago Creek districts. Many veins of this type contain moderate quantities of gold; the silvergold ratio commonly is less than $5: 1$.

Pyrite veins of type $C$ contain pyrite and in addition, chalcopyrite, tetrahedrite-tennantite, enargite (locally), sphalerite, and galena. Polybasite and pearceite are common in some of these veins. Quartz is the principal gangue mineral but carbonate minerals locally constitute part of the gangue. The silver-gold ratio commonly ranges between $5: 1$ and $15: 1$. Veins of this type constitute many of the valuable ore deposits in all the mining districts.

The galena-sphalerite veins consist dominantly of galena and sphalerite. Pyrite is ubiquitous but sparse; and copper minerals are sparse. Complex silver minerals commonly occur in this type of vein. The gangue minerals are quartz, much of which is fine grained or cryptocrystalline, a variety of carbonate minerals, and rarely barite or fluorite. The silver-gold ratio ranges from about $15: 1$ to as much as 200:1.

\section{HYPOGENE MINERAL ZONING}

A regional concentric zonal arrangement of the ores that includes all the mining districts is shown by the distribution of veins of contrasting mineralogy (fig. 8). A large irregular central area containing predominantly pyrite veins (types $A$ and $B$ ) is surrounded by areas containing predominantly galena-sphalerite veins. Pyrite veins containing copper, lead, and zinc (type $C$ ) occur in an intermediate area. In the southern part of the region two small isolated areas of pyrite veins (types $A$ and $B$ ) occur within large areas of galenasphalerite veins. A depth zoning also may exist, but data are too sparse to confirm this.

The terminology used in this report to distinguish the zones is the same as that used previously in the Central City district (Sims, 1956a, fig. 2; Sims, Drake, and Tooker, 1963). The core area containing pyrite veins of types $A$ and $B$ is referred to as the central zone, the intermediate area of transitional pyrite veins (type $C$ ) is the intermediate zone, and the outer zone of galenasphalerite veins is the peripheral zone.

A zonal arrangement of the ores was first recognized by Collins (1903, p. 480) in the Central City and Idaho Springs districts. Collins found by using silver-gold ratios that at Central City a central oval area containing gold veins was surrounded by a circular belt of veins chiefly valuable for their silver content. Spurr and others (1908, p. 97), Bastin and Hill (1917), and Lovering and Goddard (1950, pl.9) further contributed to the knowledge of zoning.

\section{REGIONAL ZONING}

The ores of the region are arranged concentrically around a central core of pyrite veins that is 6 miles long in a northeast direction and a maximum of 3 miles wide (fig. 8).

The central zone predominantly contains pyrite veins of type $A$, which are nearly barren, but at places it contains valuable gold- and copper-bearing pyrite veins of type $B$. The copper-rich pyrite veins occur near the outer margin of the zone at Central City (Sims, 1956a), along the southeast margin of the zone in the Idaho Springs district, and in the area northeast of Dumont in the Lawson-Dumont-Fall River district.

The central zone is partly surrounded by a narrow belt (intermediate zone) that contains pyrite veins of type $C$, which are valuable for their gold, copper, lead, and zinc content. The belt is consistently half a mile or more wide at Central City and along the southeast margin of the core in the Idaho Springs district (fig. 8). It includes many of the more important producing veins at Central City and Idaho Springs. A narrow lenticular belt of similar pyrite veins is present locally along the northwest margin of the central zone in the Lawson-Dumont-Fall River district.

The peripheral area of galena-sphalerite veins is large and includes the western part of the Lawson-DumontFall River district, most of the Freeland-Lamartine and Chicago districts, and part of the Idaho Springs and Central City districts. Although most of the veins within this area are chiefly valuable for their silver content, a few are gold bearing.

A small oval area of pyrite veins south of Idaho Springs occurs within the large peripheral zone (fig. 8). It contains pyrite veins of types $A$ and $B$ (pl. 1), laterally it passes into an area of galena-sphalerite veins.

In the Freeland-Lamartine district, three major vein systems have central segments of pyrite veins which 


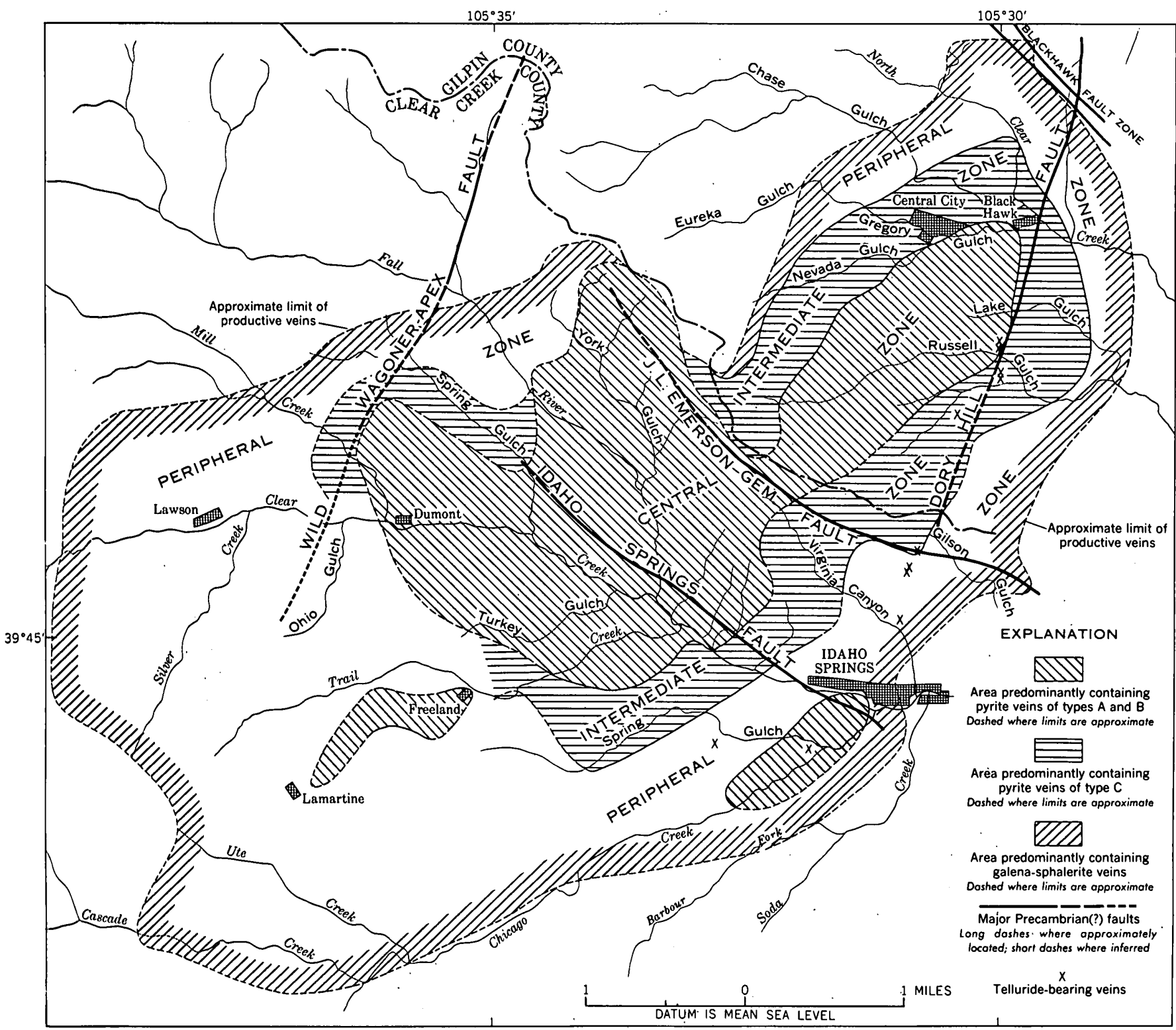

Geology compiled by P. K. Sims, 1956

Frodne 8.-Map showing zonal arrangement of the ores in the central part of the Front Range mineral belt.

change laterally into galena-sphalerite veins (Harrison, 1955 , p. 318; Harrison and Wells, 1956, p. 85-87). The geographic pattern of this zoning is rectilinear along the trace of the vein rather than concentric about a subcircular core, and clearly does not involve several veins as it does in other parts of the region. This area is arbitrarily shown on figure 8 by outlining the pyritic parts of the three vein systems.

Although the demarcation between zones is necessarily somewhat arbitrary because the different types of veins are gradational, the zonal pattern is well defined in most of the region, and particularly in the Central City district (Sims, 1956a, p. 744-745); the boundaries between zones can be established within small limits. At places, however, the boundaries are less definite, either because little is known of the mineralogy of the veins or because there is some mixture of vein types of different mineralogy (compare fig. 8 and pl. 1). Where veins of different mineralogy are mixed, the boundary between zones has been drawn on the basis of the most abundant vein type. For example, northwest of Idaho Springs, on the south slope of Bellevue Mountain (pl. 1 ), the boundary between the central zone and intermediate zone is placed east of the easternmost pyrite vein of type $B$ (fig. 8). A few pyrite veins of type $C$ are included in the central zone. Also, within the Free- 
land-Lamartine district, a few galena-sphalerite veins are included within the small area of predominant pyrite veins, as can be seen by comparing plate 1 and figure 8 .

The gold-silver tellurides and uranium are not related to the concentric zonal arrangement of the sulfide ores. Most of the telluride deposits occur in a narrow north-northeastward-trending zone that extends from Black Hawk to a point south of Idaho Springs (fig. 8 and pl. 1). The deposits occur in veins of various trends, near the intersection of the veins with the Dory Hill fault and its inferred southward projection. The position of uranium deposits in the sulfide mineral zoning pattern is described on pages $48-49$.

\section{LONGITUDINAL ZONING OF VEINS}

Several long, persistent vein systems in the region show a marked change in mineralogy along their strike. This zoning along a single vein has been termed longitudinal zoning by Harrison (1955, p. 318).

Longitudinal zoning is conspicuously developed along some vein systems in the Freeland-Lamartine district (Harrison, 1955; Harrison and Wells, 1956, p. 85-87, pl. 5). Three vein systems, the Freeland, the Lamartine-Great Western, and the Lone Tree, occupy cymoid fractures formed by a combination of fractures of different ages. These three systems have central segments of pyrite veins that pass laterally into galenasphalerite veins at both ends.

In the Idaho Springs and Central City districts several persistent vein systems or lodes that cross the zoned districts have a pronounced longitudinal zoning. At Central City, the important California-GardnerMammoth vein system, which consists of several long, in echelon vein fissures, can be traced along its strike for about 12,000 feet. It extends westward from the central zone of the district through the intermediate zone into the peripheral zone, and accordingly changos from a pyrite vein to a galena-sphalerite vein. The J. L. Emerson-Gem vein system in the Idaho Springs district (fig. 8 and pl. 1) shows a similar mineralogic change along its strike. It changes toward the east from a pyrite vein of type $A$ through pyrite veins of types $B$ and $C$ to a galena-sphalerite vein; east of the district, where the fault system is known as the Floyd Hill fault (fig. 6), it is a barren fault zone.

\section{DEPTH ZONING}

Possibly a depth zoning also occurs in the region, but this cannot be demonstrated because of the lack of accessible deep mine workings. Veins have been cut at depths of more than 1,500 feet in the Argo tunnel, but the writers had no opportunity to study them and earlier studies were not sufficiently detailed to provide the data needed for a definitive interpretation of zoning.

In the Freeland-Lamartine district some veins may have a vertical zoning, but the data supporting this conclusion are sparse. Harrison (1955, p. 318) found galena in the Freeland vein near the surface but absent at depth. He also (p. 318-319) stated that, "Some good zinc ore has been reported from shallow stopes on the Oneida vein, but only traces of sphalerite are present in the lower workings."

In the Central City and Idaho Springs districts several copper-lead-zinc-rich veins (pyrite veins of type $C$ ) in the intermediate zone were found, at the level of the Argo tunnel (depth of 1,500 to 2,000 feet) to be nearly barren of base-metal sulfides and to consist almost wholly of pyrite and quartz (Lovering and Goddard, 1950, p. 179). To account for this change it can be inferred that the central zone flares outward at depth in the form of a cone; according to this hypothesis the copper-lead-zinc-bearing ore would be progressively farther from the core of the district as depth increases. Such an hypothesis cannot be proved with existing data, for the interpretation is complicated by the effect of wallrocks and ore-shoot structures. Most of the large persistent ore shoots plunge outward away from the core of the zoned districts, and the better ore shoots are in host rocks favorable for the formation of ore deposits. These two factors, which produce variations in composition of the veins similar to that expected from zoning, could also explain the changes in mineralogy that have been observed in the veins.

\section{PARAGENESIS OF VEIN MINERALS}

The paragenetic depositional sequence of the main vein mineral is generally consistent throughout the mining districts in the region. Vein filling began with the deposition of quartz and pyrite and concluded with the deposition of base-metal sulfides and sulfosalts. The sulfide mineralization took place in two distinct stages, which locally resulted in the development of composite veins (see Sims, 1956a, p. 745-748, and Harrison and Wells, 1956, p. 76-78). The veins that show two stages have a pyritic vein that is broken, veined, and cemented by base-metal sulfide ore that is nearly devoid of pyrite. In the Freeland-Lamartine district (Harrison and Wells, 1956, p. 76-78), Chicago Creek district (Harrison and Wells, 1959), and locally in the Idaho Springs district, however, some veins consist of a pyritic vein that is fractured and cemented by pyritic base-metal ore.

The generalized sequence of deposition of the prin- 
cipal vein minerals (excluding pitchblende) is as follows:

1. Quartz intergrown with pyrite and rarely marcasite.

2. Sphalerite intergrown with minor amounts of pyrite. Both quartz and carbonate minerals preceded, accompanied, and followed deposition of sphalerite.

3. Chalcopyrite, tetrahedrite-tennantite, enargite, polybasite, and pearceite.

4. Galena; at many places copper minerals are virtually contemporaneous with galena.

5. Chalcopyrite (local) followed by sparse pyrite. Gold was deposited throughout the sequence, but it formed most abundantly during deposition of the basemetal sulfides.

Fracturing that reopened the veins and which was probably synchronous throughout the districts occurred after the quartz-pyrite stage of mineralization $(1$, above) and before the beginning of the base-metal stage of mineralization (2, above); this fracturing provided openings for: the deposition of the base-metal sulfides.

The tellurides probably were deposited during a distinctly later stage of mineralization than the basemetal sulfides. Some fluorite probably accompanied the telluride mineralization.

As described on page 39, uranium was deposited largely during an early stage of mineralization, prior to the deposition of the sulfide minerals.

\section{WALLROCK ALTERATION}

BY E. W. Tooker

As the altered rocks of the region and the processes leading to their formation will be described in a separate comprehensive report, they are discussed only briefly in the section that follows.

The wallrock adjacent to every vein fissure is altered to varying degrees, regardless of the size, attitude, or relative age of the vein fissure. As the principal wallrocks are grossly similar in mineralogy, chemical composition, and structure, the rocks have been altered similarly. Quartz-feldspar-mica host rocks have been altered progressively through a soft clay mineralquartz rock into a hard sericite-quartz rock adjacent to the veins. Amphibolite, a more mafic rock, on the other hand altered to a soft green clay mineral-quartz rock along the veins.

The alteration minerals are arranged parallel to vein fissures in zones (Tookel, 1956, p. 351) which, although arbitrarily established, can be recognized megascopically. The fresh rock (zone 1) grades toward the vein into weakly argillized rock (zone 2 ) in which plagioclase (oligoclase-andesine) crystals are incipiently to partly replaced by three-layer clay minerals. The next zone, strongly argillized rock (zone 3), is soft and retains the texture of the original rock, as there is a gradual but complete replacement of all plagioclase feldspar and some potassium-feldspar and biotite by montmorillonite, illite, and kaolinite mixed-layer clay minerals. The boundary of zone 3 with hard bleached sericite-recrystallized quartz-potassium feldspar rock (zone 4), the most intensely altered, is sharp. Few original textural features of the rock are preserved in zone 4.

Because most of the mine workings that were accessible during this study are comparatively shallow, it is not possible to distinguish clearly between alteration resulting from a hypogene fluid and that resulting from subsequent supergene solutions. Probably many of the veins examined by the writers were affected by solutions of both types, but owe their character mainly to hypogene altering solutions. It is clear, though, from studies in the mines on Nigger Hill (Sims, Osterwald, and Tooker, 1955 , p. 16-17), that the clay-mineral zones are widened in the supergene zone of alteration with a proportional narrowing of the sericite zone, and that montmorillonite clay minerals are the most abundant alteration minerals which are stable in this environment.

The altered rock zones are commonly wider along pyrite veins than along galena-sphalerite veins. The altered rock envelop around galena-sphalerite veins ranges in width from a few inches to as much as 5 feet, commonly widening at vein junctions and intersections and narrowing along tight parts of the vein fissures. In these veins argillic alteration dominates and the hard sericitized rock of zone 4 is commonly only a few inches wide. The altered rock along pyrite veins is from 1 foot to several feet wide, and the sericitized-silicified rock of zone 4 is markedly more prominent and commonly contains abundant disseminated pyrite.

Minerals which are stable in the amphibolite metamorphic facies environment are unstable to varying degrees along vein fissures in the hydrothermal environment. Plagioclase feldspar is least stable and alters incipiently to clay minerals in zone 2 , and it is completely changed in zone 3 . Hornblende alters in zone 2 to clay minerals, but it also is completely altered in zone 3. Biotite and potassium feldspars are metastable and remain virtually fresh in zones 2 and 3 ; biotite, however, is completely altered in zone 4 . Original microcline and recrystallized potassium feldspar occur in zone 4 ; the microcline generally is partly altered to clay minerals. The quartz content remains nearly constant throughout zones 1 to 4 , but the quartz appears to be recrystallized in zone 4. Magnetite-ilmenite alters to leucoxene and hematite and subsequently, in zone 4 , to 
pyrite. Some of the iron in the pyrite in zone 4 , however, appears to be derived from the breakdown of biotite.

The alteration of amphibolite is unique, for even the most intensely altered rock (zone 4) lacks a hard sericitized phase. This is to be expected, for the amphibolite contains sparse quartz (less than 15 percent) and little or no potassium feldspar. The silica necessary for silicification was not available during the alteration, and some excess potassium from altered hornblende and biotite combined with the iron-bearing clay minerals to form secondary biotite.

The individual clay minerals are not derived from specific parent silicate minerals, but instead several species-montmorillonite, illite, mixed-layer clay (montmorillonite-illite, and hydrobiotite) and kaolinite-can form from the feldspars and micas. The clay minerals in zone 3 in order of increasing stability are montmorillonite, illite, and kaolinite; all species, however, are present in every sample. In zone 4 the clay minerals are converted to sericite (or clay-sized white mica).

The geochemical changes during alteration largely involve modifications in the silicate structure. The major change is from the 3-dimensional silicate arrangement in feldspar to the layer lattice in clay minerals. Quartz is not transformed. Chemically the process consists of small migrations of cations and anions in interstices between closely packed relatively immobile oxygen ions. As oxygen composes about 90 percent of the volume of these rocks, alteration is affected by relatively small movements of the interstitial cations.

Chemical readjustments during alteration involve small gains in aluminum, potassium, and iron (total) and losses of silica, sodium, calcium, and magnesium. Rocks relatively rich in iron, however, lose potassium and iron during alteration. Water, carbon dioxide, and sulfur are the main ions introduced from outside the system. Calcium, magnesium, and silica are commonly fixed in the vein, as in calcite and quartz, and thus very few cations except sodium (which is detected in water analyses) are irrevocably lost to the system. The distribution of trace elements directly parallels the distribution of the major elements for which they substitute. Elements whose concentration increases toward the vein, especially in zone 4 , are those with a high affinity for sulfur. Elements with an affinity for magnesium decrease in abundance toward the vein; those which are satisfied in clay-mineral structures, such as vanadium, zinc, and titanium, are commonly concentrated in zone 3 .

The character of the altered wallrocks and the spatial relations of these rocks to the vein filling clearly indicate that alteration of the walls preceded deposition of the vein minerals. It is postulated that the alteration resulted from relatively dilute, slightly acid hydrothermal solutions which probably consisted of mixed juvenile and meteoric fluids. These solutions gradually changed the unstable minerals of the wallrocks to clay minerals. As the temperature of the system rose and the solutions became more basic, the inner margins of the walls were changed to hard sericitized rocks (zone 4 ), and ultimately pyrite was formed in the sericitized rock and in the vein fissures.

\section{GENESIS OF SULFIDE VEINS}

The ore deposits of the central part of the Front Range mineral belt are closely associated geographically and temporally with the early Tertiary porphyritic igneous rocks; accordingly the writers have concluded, in conformity with most previous workers in the Front Range, that the ores and the igneous rocks were derived from a common source. Data obtained during this study indicate that the heat and energy needed for the accumulation and transport of the metals that constitute the deposits were supplied by the magma or magmas that consolidated to form the different types of Tertiary igneous rocks. Data are not sufficient, however, to clearly establish the quantities of the metals that were derived directly from the magma and the quantities that were derived from the altered wallrocks adjacent to the fissures.

The ore-forming fluids seem to have been derived dominantly from a deep-seated source rather than from any particular type of observed intrusive, and the apex of this source, judging from the pattern of hypogene mineral zoning, must have been beneath the central pyritic core. Uranium occurs as an exception to a deep-seated-source hypothesis because it appears to have been derived in part directly from dikes of quartz bostonite porphyry that cooled some distance above the main magma chamber. (See p. 53.) Possibly the telluride ores also were derived from a local shallow (?) source, adjacent to the Dory Hill fault (compare fig. 8 and pl. 1).

From data on the geomorphic history of the Front Range and estimates of the temperatures of sulfide mineralization at the Central City district (Sims and others, 1963; Sims and Barton, 1961), it.is can be reasonably inferred that the ores in the central part of the Front Range mineral belt were deposited at depths approximately between 1 and 2 miles.

In each of the mining districts it is clear that the wallrock alteration largely preceded deposition of the sulfide ores. The hydrothermal solutions that initially altered the wallrocks probably changed gradually 
through addition of materials from the source and through changes within the fluid and at appropriate temperatures, pressures, and concentrations deposited the gangue and ore minerals. Deposition of the minerals in a well-defined zonal arrangement was in general accord with the paragenetic sequence of deposition.

The temperatures and pressures at which the sulfide ore minerals were deposited have been estimated for the Central City district from studies of sphalerite-bearing assemblinges (Sims and Barton, 1961; 1962; and Sims and others, 1963); presumably these estimates are valid in general for other districts in the central part of the Front Range mineral belt. In brief, it has been concluded for the Central City district that the zonal pattern of the sulfide ores correlates with changes in temperature, pressure, and chemical potential of sulfur of the ore-forming fluid, the veins in the outer part of the district having been formed at a lower temperature and at a lower chemical potential of sulfur than the veins in the inner part. Estimates of temperatures of formation of sphalerite from the veins in the inner part of the district range from $400^{\circ}$ to $600^{\circ} \mathrm{C}$, whereas estimates for the sphalerite in the outer part range from $150^{\circ}$ to $300^{\circ} \mathrm{C}$. The chemical potential of sulfur; as indicated by the sphalerite-bearing assemblages, decreased outward from about $10^{-2}$ to at least 10-10. (See Sims and Barton, 1961, fig. 6.)

\section{URANIUM DEPOSITS}

Pitchblende and rare hexavalent uranium minerals are local constituents of the veins. Pitchblende, the primary uranium oxide occurs in small bodies that commonly are closely associated with the sulfide ore minerals, but at places are in distinct separate fractures. The hexavalent minerals, principally metatorbernite, kasolite, and autunite, formed as the result of pitchblende oxidation in the zone of supergene alteration. They occur in galena-sphalerite veins but are not present in pyrite veins because of leaching by highly acid supergene sulfate solutions.

The uranium deposits occur in faults of all the fracture sets and tend to occur in clusters generally less than 1 square mile in area. They have no definite position in the sulfide mineral zoning of the region.

The uranium is inferred to have been derived partly from the same deep-seated magma source that yielded the sulfide ores, but a large part probably was obtained directly from shallow bodies of quartz bostonite magma that cooled as dikes above the main magma chamber. Deposits related to these local sources are near exposed bodies of quartz bostonite porphyry. Age determina. tions on uraninite from the Central City district indi. cate that the deposits were formed about 60 million years ago. Holmes (1947) has arbitrarily established 60 million years as the beginning of the Tertiary period.

\section{ABUNDANCE AND DISTRIBUTION OF URANIUM IN VEINS}

Although uranium occurs in many veins throughout the region, it constitutes ore in only a few. Of 141 localities in the region known to contain abnormally radioactive vein material, 62 mines, including 16 that have produced uranium ore, contain selected material that assays 0.10 percent equivalent uranium or more. The remainder of the localities are not known to have any material of ore grade.

To determine the distribution of uranium-bearing veins, a radioactivity survey was made of the region, using portable ground instruments. All mine dumps and accessible underground workings were checked for radioactivity and, because the grade cannot be determined accurately in the field, samples of the radioactive material were collected and analyzed for equivalent uranium and uranium. The instruments and methods used in the radioactivity survey have been described previously (Wells and Harrison, 1954, p. 2-3). Additional data applicable to prospecting for radioactivity in regions of this type are given by Johnson (1954).

In general, determinations of uranium and equivalent uranium (radioactivity) on unaltered pitchblende ores indicated approximate equilibrium or a small excess of uranium over equivalent uranium; determinations on material containing hexavalent uranium minerals show a slight excess of uranium over equivalent uranium. Some samples from pyritic mine dumps or from nearsurface parts of some pyrite veins, however, indicated a marked disequilibrium. These samples contained less uranium than the radioactivity measurements indicated. This disequilibrium can be accounted for by an excess of radium and other daughter products of uranium. Phair and Levine (1953) demonstrated that pitchblende from pyritic dumps oxidizes rapidly. The uranium is leached by acid sulfate solutions derived from pyrite, and radium and lead (and other disintegration products) remain in the original material in approximately proportional amounts; accordingly the equivalent uranium analyses indicate the approximate uranium content of the original material when removed from the vein.

The analyses of the radioactive vein materials can be grouped according to percentage equivalent uranium into three classes: (a) low abnormal radioactivity, between 0.005 and 0.020 percent; (b) moderate, between 0.021 and 0.099 percent; and (c) high, 0.10 percent or more. The analyses, grouped according to the classification given above, are shown in tables 9,10 , and 11 . 
TABLE 9.-Uranium analyses from localities with high abnormal radioactivity ${ }^{1}$

[Analyses by U.S. Geol. Survey]

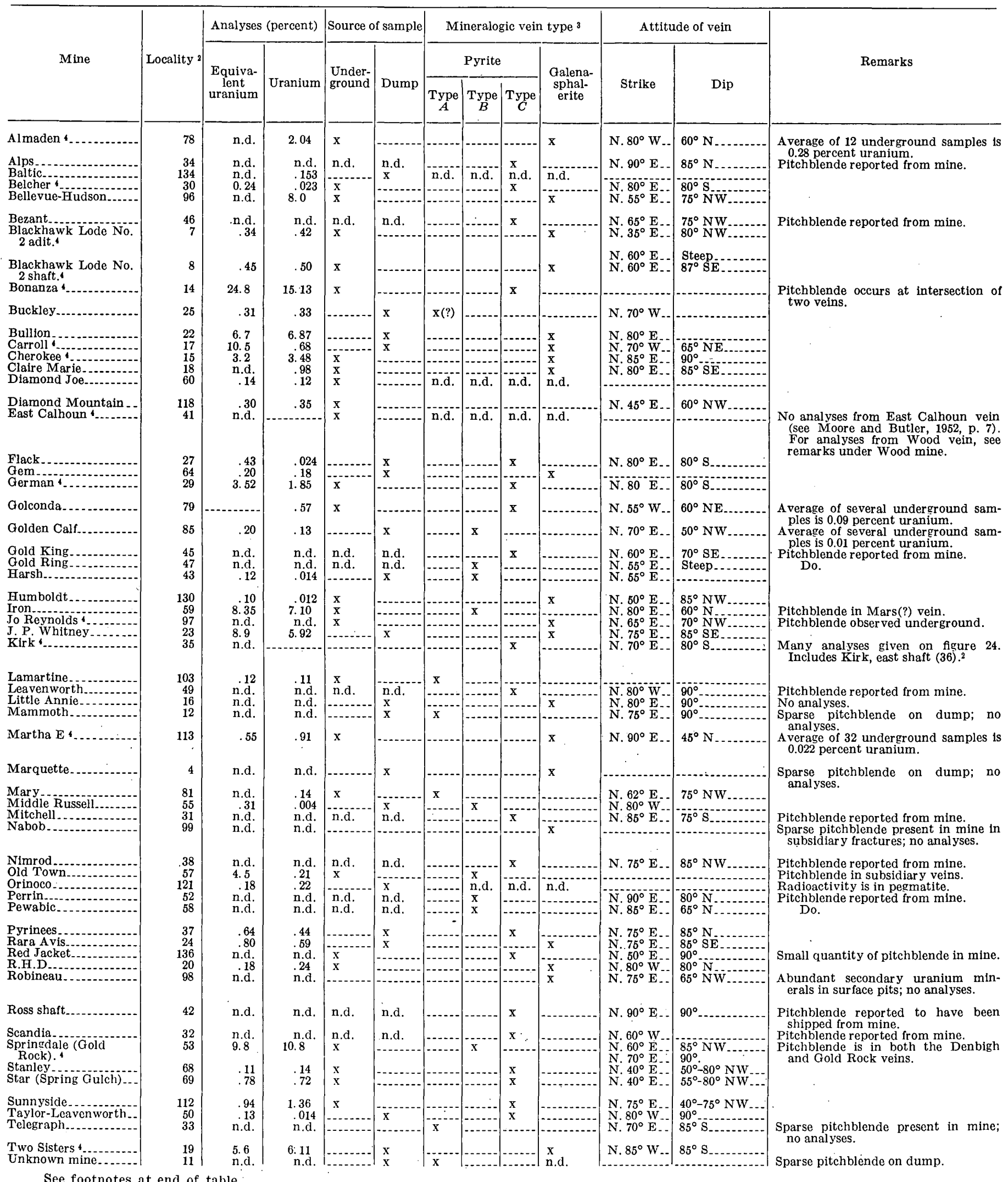


TABLE 9.-Uranium analyses from localities with high abnormal radioactivity - Continued

[Analyses by U.S. Geol. Survey]

\begin{tabular}{|c|c|c|c|c|c|c|c|c|c|c|c|c|}
\hline \multirow{3}{*}{ Mine } & \multirow{3}{*}{ Locality 2} & \multicolumn{2}{|c|}{ Analyses (percent) } & \multicolumn{2}{|c|}{ Source of sample } & \multicolumn{4}{|c|}{ Mineralogic veln type ${ }^{3}$} & \multicolumn{2}{|c|}{ Attitude of vein } & \multirow{3}{*}{ Remarks } \\
\hline & & \multirow{2}{*}{$\begin{array}{l}\text { Equiva- } \\
\text { lent } \\
\text { uranium }\end{array}$} & \multirow[b]{2}{*}{ Uranium } & \multirow{2}{*}{$\begin{array}{l}\text { Under- } \\
\text { ground }\end{array}$} & \multirow[b]{2}{*}{ Dump } & \multicolumn{3}{|c|}{ Pyrite } & \multirow{2}{*}{$\begin{array}{l}\text { Galena- } \\
\text { sphal- } \\
\text { erite }\end{array}$} & \multirow[b]{2}{*}{ Strike } & \multirow[b]{2}{*}{ Dip } & \\
\hline & & & & & & $\underset{A}{\text { Type }}$ & Type & Type & & & & \\
\hline West Calhoun $4 . . . .$. & 44 & n.d. & n.d. & $-\ldots$ & & o & $-\cdots$ & $x$ & - & N. $60^{\circ} \mathrm{E}$ & $85^{\circ} \mathrm{SE}$ & mont \\
\hline Wood $4 . . . . . . .$. & 39 & 9.3 & 9.94 & $\mathrm{x}$ & & & $\cdots$ & $\mathrm{x}$ & & N. $85^{\circ} \mathrm{E} .$. & & $\begin{array}{l}\text { no analyses. } \\
\text { See also Moore and Butler (1952, p. } \\
\text { 4-6); Drake (1957). Includes Wood } \\
\text { east shaft (40). }\end{array}$ \\
\hline
\end{tabular}

1 Includes some mines having high abnormal radioactivity, but for which there are no analyses.

Numbers refer to locations shown on plate 3 .

TABLE 1.0.-Uranium analyses from localities with moderate abnorrnal radioactivity ${ }^{1}$

[Analyses by U.S. Geol. Survey]

\begin{tabular}{|c|c|c|c|c|c|}
\hline \multirow{2}{*}{ Mine } & \multirow{2}{*}{$\begin{array}{l}\text { Lncal- } \\
\text { ity }{ }^{2}\end{array}$} & \multicolumn{2}{|c|}{ Analyses (percent) } & \multicolumn{2}{|c|}{ Source of sample } \\
\hline & & $\begin{array}{c}\text { Equivalent } \\
\text { uranlum }\end{array}$ & Uranlum & $\begin{array}{l}\text { Under- } \\
\text { ground }\end{array}$ & Dump \\
\hline $\begin{array}{l}\text { Albro } \\
\text { Alma Jincoln } \\
\text { Arladne... } \\
\text { Ayres-Loaven worth. } \\
\text { Bollo Creolo... }\end{array}$ & $\begin{array}{r}84 \\
67 \\
116 \\
51 \\
115\end{array}$ & $\begin{array}{l}0.069 \\
.089 \\
.039 \\
.024 \\
.037\end{array}$ & $\begin{array}{l}0.091 \\
.063 \\
.032 \\
.001 \\
.033\end{array}$ & $\begin{array}{l}x \\
x \\
x\end{array}$ & $\begin{array}{l}x \\
x\end{array}$ \\
\hline $\begin{array}{l}\text { Brazll, lower tunnel. } \\
\text { Chicago } \\
\text { Crazy Girl } \\
\text { Eldorado } \\
\text { Ellery..... }\end{array}$ & $\begin{array}{r}100 \\
70 \\
114 \\
48 \\
137\end{array}$ & $\begin{array}{l}.040 \\
.032 \\
.033 \\
.031 \\
.022\end{array}$ & $\begin{array}{l}.048 \\
.033 \\
.026 \\
.024 \\
.012\end{array}$ & $\begin{array}{ll}-1 \\
\mathbf{x} \\
\mathbf{x}\end{array}$ & $\begin{array}{l}x \\
x \\
x\end{array}$ \\
\hline $\begin{array}{l}\text { Gold Chloride } \\
\text { Gomer... } \\
\text { II K } \\
\text { Jonnie Lind No. 1 } \\
\text { Little Johnie, middle tunnel. }\end{array}$ & \begin{tabular}{r|}
83 \\
71 \\
5 \\
140 \\
108
\end{tabular} & $\begin{array}{l}.029 \\
.068 \\
.030 \\
.025 \\
.037\end{array}$ & $\begin{array}{l}.003 \\
.072 \\
.004 \\
.025 \\
.033\end{array}$ & $x$ & $\begin{array}{l}\mathbf{x} \\
\mathbf{x} \\
\mathbf{x}\end{array}$ \\
\hline $\begin{array}{l}\text { MAB } \\
\text { Mint } \\
\text { Muscovite } \\
\text { Now Bedford } \\
\text { Poor Min..... }\end{array}$ & \begin{tabular}{r|}
65 \\
2 \\
124 \\
66 \\
101
\end{tabular} & $\begin{array}{l}.035 \\
.035 \\
.047 \\
.024 \\
.028\end{array}$ & $\begin{array}{l}.036 \\
.003 \\
.046 \\
.014 \\
.023\end{array}$ & $x$ & $\begin{array}{l}\mathbf{x} \\
\mathbf{x} \\
\mathrm{x}\end{array}$ \\
\hline $\begin{array}{l}\text { Powhatan... } \\
\text { Saginaw } \\
\text { Silient Friend } \\
\text { Silver Ring.... } \\
\text { Star (Belleve Mountain) }\end{array}$ & $\begin{array}{r}6 \\
73 \\
9 \\
123 \\
138\end{array}$ & $\begin{array}{l}.050 \\
.036 \\
.057 \\
.028 \\
.041\end{array}$ & $\begin{array}{l}.096 \\
.004 \\
.004 \\
.028 \\
.002\end{array}$ & 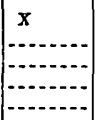 & $\begin{array}{l}x \\
x \\
x \\
x\end{array}$ \\
\hline $\begin{array}{l}\text { Trensure Vault } \\
\text { Unknown tunnel..... }\end{array}$ & $\begin{array}{r}135 \\
92\end{array}$ & $\begin{array}{c}.04 \\
\text { n.d. }\end{array}$ & $\begin{array}{l}\text { n.d. } \\
.050\end{array}$ & $\mathrm{x}$ & $\mathrm{x}$ \\
\hline
\end{tabular}

1 Includes some mines having moderate abnormal radioactivity, but for which there are no analyses.

refer to locations shown on plate 3 .

n.d. means not determined.

These analyses in no way indicate the average grade of uranium-bearing materials; instead they generally indicate the maximum known grade determined from available samples.

The localities with high abnormal radioactivity, including 16 mines from which uranium ore has been mined (table 9), cannot be fully evaluated, for many of the mines are not accessible, and the only knowledge of the radioactive material is gained from dump samples. Many others, however, are accessible, and the uranium occurrences are described in the section on the mines.
3 See text, p. 23.

pros broduced.

TABLE 11.-Uranium analyses from localities with low abnormal radioactivity ${ }^{2}$

[Analyses by U.S. Geol. Survey]

\begin{tabular}{|c|c|c|c|c|c|}
\hline \multirow{2}{*}{ Mine } & \multirow{2}{*}{ Locallty ${ }^{2}$} & \multicolumn{2}{|c|}{ Analyses (percent) } & \multicolumn{2}{|c|}{ Source of sample } \\
\hline & & $\begin{array}{c}\text { Equivalent } \\
\text { uranium }\end{array}$ & Uranium & $\begin{array}{l}\text { Under- } \\
\text { ground }\end{array}$ & Dump \\
\hline $\begin{array}{l}\text { Alpine } \\
\text { Ashland } \\
\text { Bell of the west... } \\
\text { Big Chlef } \\
\text { Black Lode }\end{array}$ & $\begin{array}{r}122 \\
63 \\
106 \\
110 \\
01\end{array}$ & $\begin{array}{r}0.008 \\
.020 \\
.018 \\
.006\end{array}$ & $\begin{array}{r}0.002 \\
.020 \\
.002 \\
.007\end{array}$ & $\begin{array}{l}x \\
- \\
-\end{array}$ & $\begin{array}{l}\mathbf{x} \\
\mathbf{x} \\
\mathbf{x} \\
\mathbf{x}\end{array}$ \\
\hline $\begin{array}{l}\text { Blackwood... } \\
\text { Bruce } \\
\text { Brunswick } \\
\text { Dixie } \\
\text { Eclipse }\end{array}$ & $\begin{array}{l}126 \\
119 \\
132 \\
128 \\
125\end{array}$ & $\begin{array}{l}.011 \\
.009 \\
.008 \\
.012 \\
.006\end{array}$ & $\begin{array}{l}.005 \\
.007 \\
.002 \\
.009 \\
.003\end{array}$ & & $\begin{array}{l}\mathbf{x} \\
\mathbf{x} \\
\mathbf{x} \\
\mathbf{x} \\
\mathbf{x}\end{array}$ \\
\hline $\begin{array}{l}\text { Estella } \\
\text { Golden Opportunity } \\
\text { Gold Quartz } \\
\text { Harrisburg } \\
\text { Ida May }\end{array}$ & $\begin{array}{r}3 \\
58 \\
77 \\
105 \\
75\end{array}$ & $\begin{array}{l}.010 \\
.005 \\
.019 \\
.015\end{array}$ & $\begin{array}{l}.012 \\
.001 \\
.004 \\
.013\end{array}$ & $\begin{array}{l}x \\
\cdots \\
\cdots\end{array}$ & $\begin{array}{l}\mathbf{x} \\
\mathbf{x} \\
\mathrm{x}\end{array}$ \\
\hline $\begin{array}{l}\text { Katie Emmett. } \\
\text { Keith } \\
\text { Lawrence (Philadelphia) } \\
\text { Little Johnle, lower tunnel. } \\
\text { Lone Tree. }\end{array}$ & $\begin{array}{r}131 \\
90 \\
72 \\
107 \\
104\end{array}$ & $\begin{array}{l}.018 \\
.011 \\
.017 \\
.006\end{array}$ & $\begin{array}{l}.004 \\
.013 \\
.005\end{array}$ & $\mathrm{x}$ & $\begin{array}{l}x \\
x \\
x \\
x\end{array}$ \\
\hline $\begin{array}{l}\text { Louis. } \\
\text { Major C C.......... } \\
\text { Mercer County... } \\
\text { Miller } \\
\text { old Chief tunnel... }\end{array}$ & $\begin{array}{r}21 \\
88 \\
28 \\
117 \\
86\end{array}$ & $\begin{array}{l}.005 \\
.014 \\
.007 \\
.014 \\
\text { n.d. }\end{array}$ & $\begin{array}{l}.002 \\
.001 \\
.007 \\
.001 \\
\text { n.d. }\end{array}$ & \begin{tabular}{l}
$\cdots$ \\
$\cdots$ \\
\hdashline \\
$x$
\end{tabular} & $\begin{array}{l}\mathrm{x} \\
\mathrm{x} \\
\mathrm{x}\end{array}$ \\
\hline $\begin{array}{l}\text { Old Settler tunnel. } \\
\text { Old Settler shaft } \\
\text { Old Stag } \\
\text { Overta and Little Ruby } \\
\text { Pennsylvania.. }\end{array}$ & $\begin{array}{r}109 \\
111 \\
102 \\
87 \\
74\end{array}$ & $\begin{array}{l}.009 \\
.008 \\
.007 \\
\text { n.d. } \\
\text { n.d. }\end{array}$ & $\begin{array}{l}.006 \\
.008 \\
.002 \\
\text { n.d. } \\
\text { n.d. }\end{array}$ & \begin{tabular}{c}
- \\
\hdashline $\bar{x}$ \\
\hdashline- \\
---
\end{tabular} & $\begin{array}{l}\mathbf{x} \\
\mathbf{x} \\
\mathbf{x}\end{array}$ \\
\hline $\begin{array}{l}\text { Pewabic tunnel } \\
\text { Rocky Mountain Terror } \\
\text { Seven-Forty (?) } \\
\text { Shafter } \\
\text { Silver Link }\end{array}$ & $\begin{array}{r}10 \\
54 \\
76 \\
139 \\
129\end{array}$ & $\begin{array}{l}.012 \\
.017 \\
\text { n.d. } \\
\text { n.d. } \\
.007\end{array}$ & $\begin{array}{l}.010 \\
.001 \\
\text { n.d. } \\
\text { n.d. } \\
.002\end{array}$ & \begin{tabular}{c}
$-\cdot$ \\
\hdashline- \\
\hdashline \\
--
\end{tabular} & $\begin{array}{l}\mathrm{x} \\
\mathrm{x} \\
\mathrm{x}\end{array}$ \\
\hline $\begin{array}{l}\text { Standard } \\
\text { Tolland County... } \\
\text { Two Brothers.... } \\
\text { Unknown mine } \\
\text { Unknown tunnel. }\end{array}$ & $\begin{array}{r}80 \\
133 \\
61 \\
94 \\
95\end{array}$ & $\begin{array}{l}\text { n.d. } \\
.012 \\
.009 \\
.005 \\
.011\end{array}$ & $\begin{array}{l}\text { n.d. } \\
.008 \\
.001 \\
.003 \\
.002\end{array}$ & \begin{tabular}{l}
- \\
\hdashline- \\
\hdashline- \\
\hdashline- \\
\hdashline-
\end{tabular} & $\begin{array}{l}\mathbf{x} \\
\mathbf{x} \\
\mathbf{x} \\
\mathbf{x}\end{array}$ \\
\hline $\begin{array}{l}\text { Unknown mine } \\
\text { Unknown mine } \\
\text { Unknown tunnel } \\
\text { Unknown mine } \\
\text { Unknown tunnel. }\end{array}$ & $\begin{array}{r}1 \\
120 \\
89 \\
93 \\
82\end{array}$ & $\begin{array}{l}.007 \\
.009 \\
.010 \\
.007 \\
.011\end{array}$ & $\begin{array}{l}.001 \\
.007 \\
.003 \\
.008 \\
.006\end{array}$ & \begin{tabular}{l}
$-\cdot$ \\
\hdashline- \\
\hdashline- \\
\hdashline- \\
--
\end{tabular} & $\begin{array}{l}\mathbf{x} \\
\mathbf{x} \\
\mathrm{x} \\
\mathrm{x}\end{array}$ \\
\hline $\begin{array}{l}\text { Upper East Lake } \\
\text { Wallace } \\
\text { Wright(?) }\end{array}$ & $\begin{array}{r}62 \\
127 \\
141\end{array}$ & $\begin{array}{l}\text { n.d. } \\
.014 \\
.006\end{array}$ & $\begin{array}{l}\text { n.d. } \\
.006 \\
\text { n.d. }\end{array}$ & 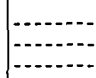 & $\begin{array}{l}x \\
x\end{array}$ \\
\hline
\end{tabular}

I Includes some mines having low abnormal radioactivity, but for which there re no analyses.

2 Numbers refer to locations shown on plate 3 . n.d. means not determined. 
Although abnormally radioactive veins are present in all the mining districts (pl. 3), most of the veins that have high abnormal radioactivity and most that have been mined for uranium ore are in the Central City district. The deposits tend to be clustered in small areas. The largest cluster, in the Quartz Hill area of the Central City district, is about 1 square mile in area. Thirty-three mines within this area contain abnormally radioactive veins and more than half of these mines contain material of ore grade. Other clusters in the Central City district, which are smaller but contain economically important deposits, are in Eureka Gulch, Silver Hill, and lower Russell Gulch. In the Fall River area, a small cluster of three deposits is present about 2 miles above the junction with Clear Creek.

\section{MINERALOGY}

Pitchblende, the primary uranium mineral in the veins, is altered at places to hexavalent uranium minerals, such as hydrous uranium phosphates, silicates, sulfates, and carbonates. Torbernite, metatorbernite, autunite, and kasolite are the most abundant secondary minerals. Secondary uranium minerals also occur in the altered zones of the uraninite-bearing pegmatites, and these are included in the minerals listed below.

\section{PitChBLENDE}

Pitchblende is used in this report as a mining term for the black uranium minerals that occur in the veins; it is analogous to the terms "limonite" or "wad." As such it includes black uranium oxidies that range widely in $\mathrm{UO}_{3}: \mathrm{UO}_{2}$ ratio, state of hydration, structure, and specific gravity. The use of the term "uraninite" is justified only when the $\mathrm{UO}_{3}: \mathrm{UO}_{2}$ ratio is known to be low from (1) chemical analysis for $\mathrm{UO}_{2}$ and $\mathrm{UO}_{3}(2)$ specific gravity determinations, or (3) X-ray diffraction studies, and when the mineral can be shown to have the face-centered cubic fluorite lattice.

Unlike the vein pitchblende, the black uranium oxide in the pegmatites is wholly uraninite. It has a low $\mathrm{UO}_{3}: \mathrm{UO}_{2}$ ratio, the face-centered cubic fluorite lattice, and contains a few percent of thorium.

\section{TEXTURE}

The pitchblende characteristically occurs as rotund forms which are included under the term "colloform" (Bastin, 1950, p. 25-32). Several types of textural forms are present in the ores, and except for the scarcity of large botryoidal forms, they are nearly identical to those described by Kidd and Haycock (1935, p. 896898 ; pls. 63-67) from Great Bear Lake, Canada.

The forms characteristic of the pitchblende are: spheroidal grains, vein forms, pellets, and rarely "cellu- lar" or dendritic forms. Although each type is distinctive, the forms grade into one another through gradual changes in texture.

Spheroidal grains as much as $2 \mathrm{~mm}$ in diameter and aggregates of these grains are probably the most common forms in the pitchblende ore (figs. 9-12). Typically they have smooth, round outer (younger) sur-

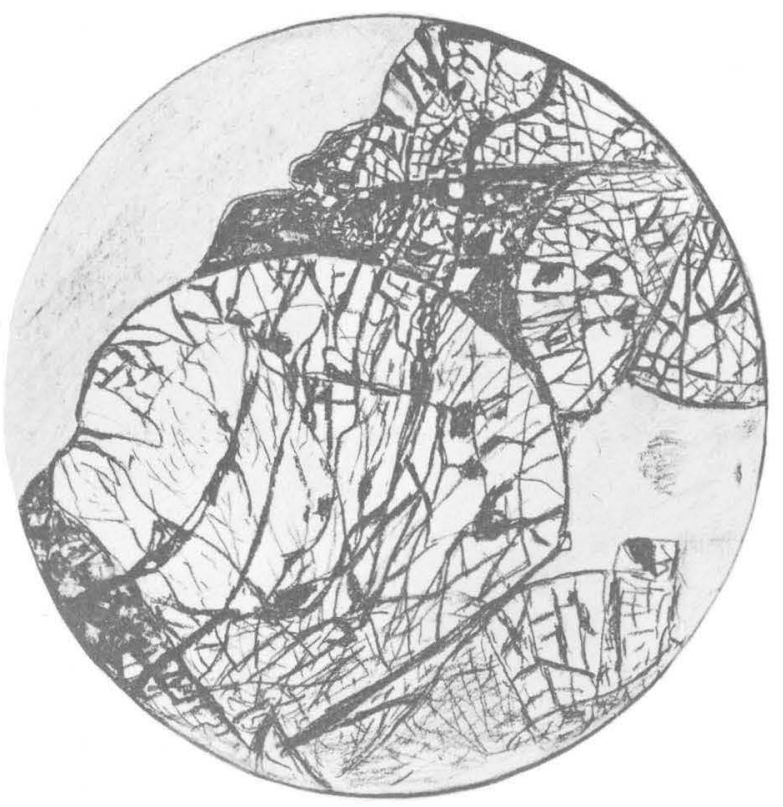

Figure 9.-Camera lucida drawing of polished surface of pitchblende ore from the J. P. Whitney mine, Central City district, showing spheroidal outline of pitchblende. The pitchblende has faint radial and concentric shrinkage eracks; both the pitchblende and the quartz (black) are fractured. Diameter of cirele is $3.3 \mathrm{~mm}$.

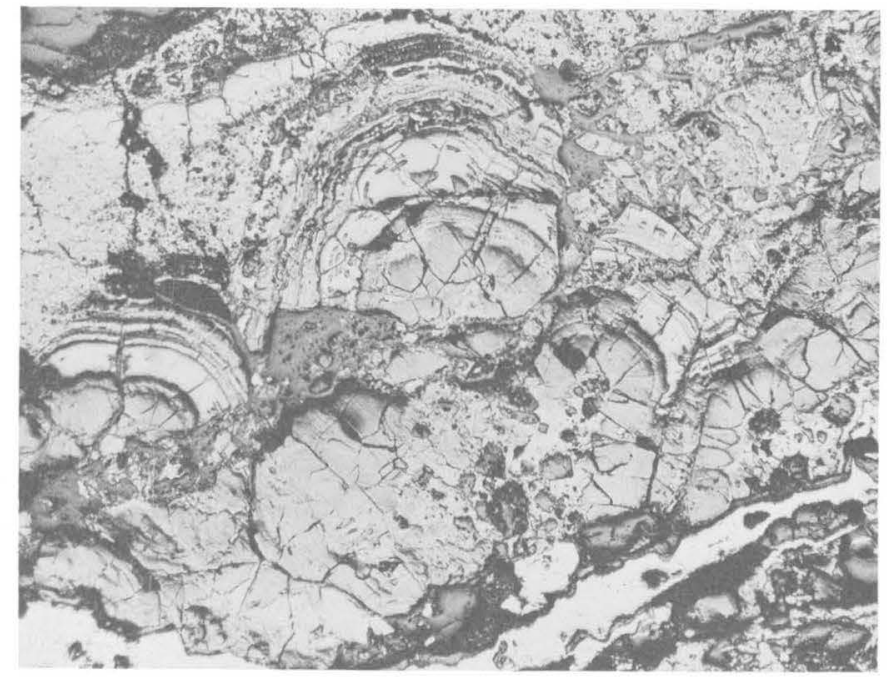

Frgure 10.-Photomicrograph of a polished surface of ore from the Flack mine, Central City district, showing pitchblende with a welldeveloped concentric layering. Some spheroidal forms are broken and recemented by quartz (dark gray). The pitchblende forms are cut by an irregular veinlet of marcasite (white). $\quad \times 48$. 


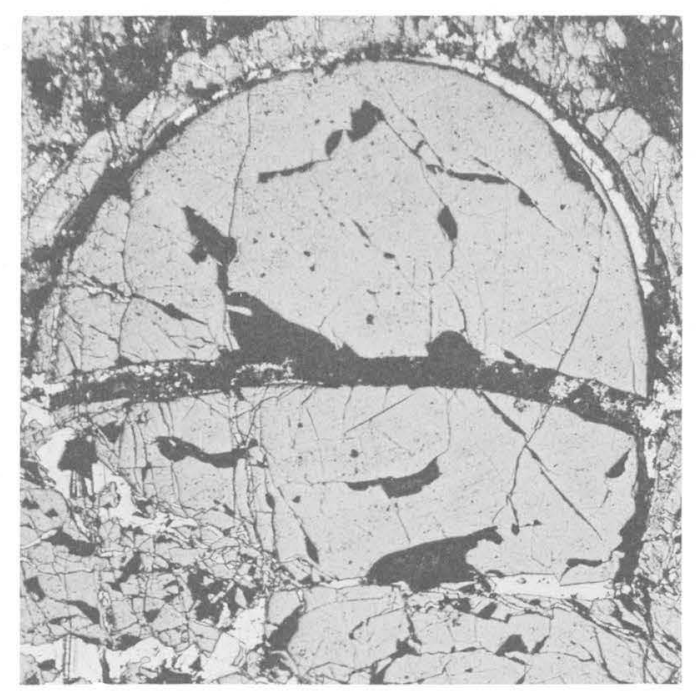

FIgURE 11.-Photomicrograph of a polished section of ore, J. P. Whitney mine, showing galena in fractures within colloform pitchblende. Galena and quartz fill a concentric shrinkage crack near the margin of the large spheroidal grain, and galena fills numerous irregular fractures of tectonic origin, $\times 48$.

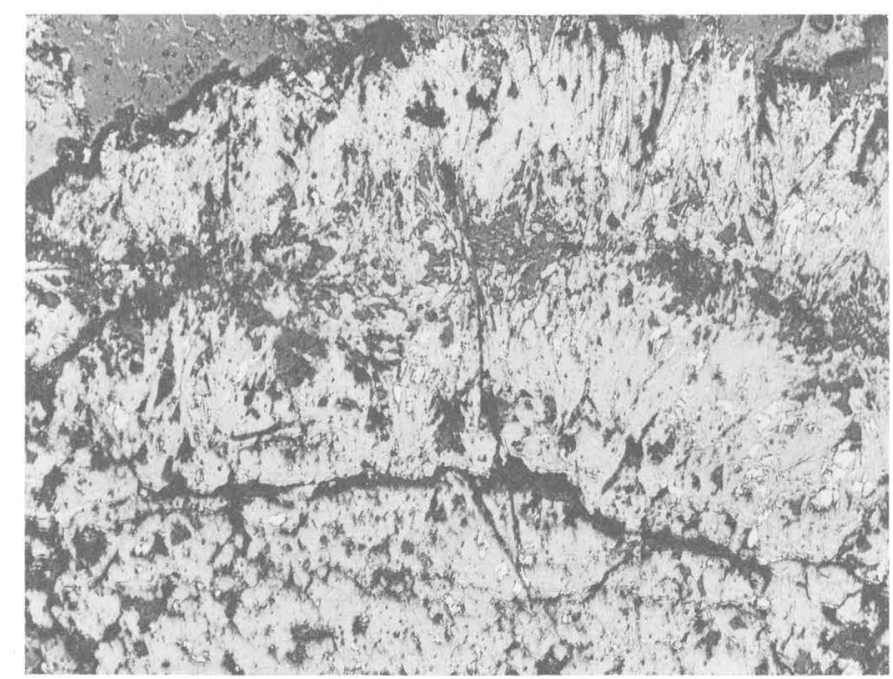

Figure 12.-Photomicrograph of a polished surface of ore from the Jo Reynolds mine, Lawson-Dumont-Fall River district, showing colloform pitchblende. Quartz (dark gray) occurs as an ill-defined thin layer near the outer margin of the grain. Galena (white) embays the pitchblende. The pitchblende in the margins of the grain has a pronounced bladed structure that is nearly normal to the outer (younger) rotund surface, $\times 131$

faces, as shown in figures 9 and 11, and irregular and locally ragged inner margins. Some of the forms appear to be nearly perfect spheres. Large forms in which the botryoidal surfaces are visible to the naked eye are rare, but botryoids as much as 1 inch across have been found in the Kirk mine (R. R. Hinckley, oral communication, 1954). The spheroidal forms commonly have radial and rarely concentric fractures (fig. 9), which, because they are confined to the mineral, are probably syneresis or shrinkage cracks (Bastin, 1950, p. 29). A few spheroidal forms have a pronounced concentric layering (fig. 10) which results from thin alternating layers of pitchblende and quartz or from alternating layers of pitchblende of variable composition. In figure 10, the very thin, slightly irregular, dark-gray concentric layers in the large grain in the upper part of the photomicrograph are quartz. The light-gray and medium-gray layers (near the center of the same grain) are pitchblende; the pitchblende in the light-gray layer is harder and has a higher reflectivity than that of the inner medium-gray layer. Probably the layering in this specimen has been accentuated by oxidation. Similar alternations of pitchblende and quartz are present in the spheroidal grain shown in figure 12. The quartz occurs as a thin highly irregular concentric layer near the outer margin of the grain; it also is erratically dispersed through the more homogeneous pitchblende. The pronounced bladelike or fibrous structure in the outer layer of the colloform pitchblende, which is normal to the outer rounded surface, was not observed elsewhere, and its origin is not known. Possibly, however, the texture is an expression of the fibrous texture observed by X-ray diffraction examination of certain botryoidal pitchblende specimens by Croft (1954, p. 13-20). Croft $(1954$, p. 16) noted in specimens from many localities, including the Wood mine in the Central City district, that the X-ray pattern of botryoidal samples, thin veinlets, and samples taken close to the vein wall of thick veins showed an apparent fibrous structure, with the fiber axis being the pole of the (111) planes and the fibers having random rotation with respect to one another.

In many hand specimens pitchblende occurs in narrow persistent stringers as much as $1 \mathrm{~mm}$ wide which to the naked eye appear to be fissure veinlets. Under the reflecting microscope, however, they are seen to be irregular forms which have one well-developed round surface, and accordingly they appear to have developed in a manner similar to the spheroidal grains. The stringers occur in quartz. The interference surfaces (Bastin, 1950, p. 31) between different parts of the mineral are straight (fig. 13); these boundaries resemble the nearly straight contacts of biscuits in a pan. The inner margins of curved stringers are ragged; the outer margins are smooth slightly curved surfaces. Commonly the stringers are fractured and filled with later sulfide minerals (fig. 14), similar to the spheroidal forms (fig. 11).

Rarely, the pitchblende occurs as tiny pellets less than $1 \mathrm{~mm}$ in diameter that resemble oolites (fig. 15). These forms are identical to the spherulitic forms described 


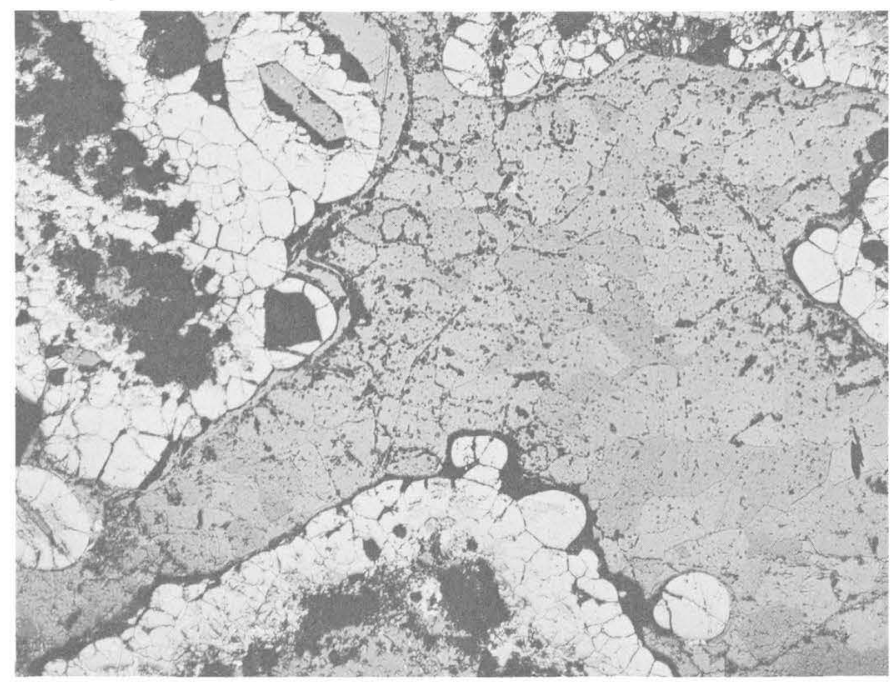

Figure 13.-Photomicrograph of a polished surface of ore from the Jo Reynolds mine, Lawson area, showing small veinlets of pitchblende in quartz (gray). Some small colloform grains have quartz cores. $\times 48$.

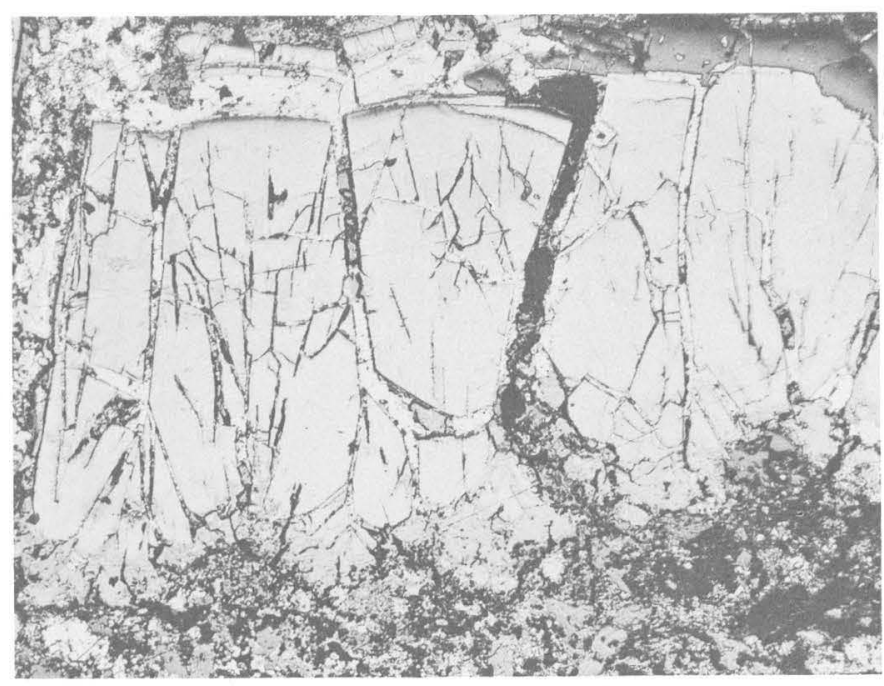

Figure 14.-Photomicrograph of a polished surface of ore from the Carroll mine, Central City district, showing veinlet of pitchblende. Post-consolidation movement along radial cracks in the pitchblende has displaced adjacent segments; some cracks are partly filled with galena (white). The black areas in the lower part of the photo are sooty pitchblende formed by the alteration of the hard dense min eral. $\times 48$

by Kidd and Haycock (1935, p. 897, pl. 65, fig. 3). The pellets occur in swarms within quartz, and they grade into massive pitchblende.

Cellular or dendritic forms were observed in a few sections, but so far as known they are sparse. They occur in quartz, and appear to be transitional to spheroidal forms.

All types of forms are locally fractured and brecciated as the result of movements along the vein fissures after the consolidation of the pitchblende. The broken pitchblende fragments commonly are cemented by

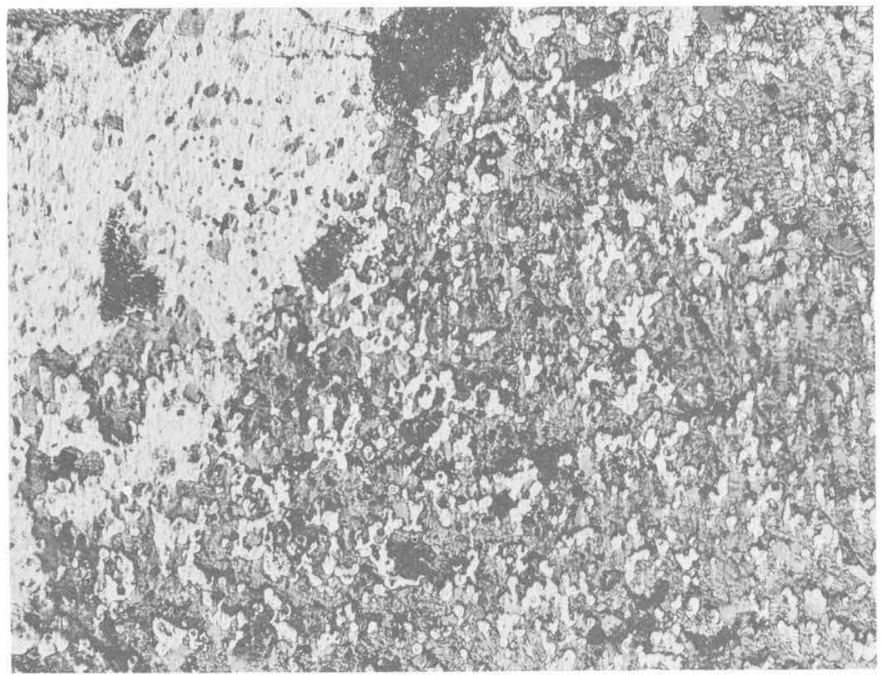

Figure 15.-Photomicrograph of a polished surface of ore from the Flack mine, Central City district, showing pellet texture of pitchblende. The pellets, which tend to coalesce, grade toward the left into more massive pitchblende. $\times 131$.

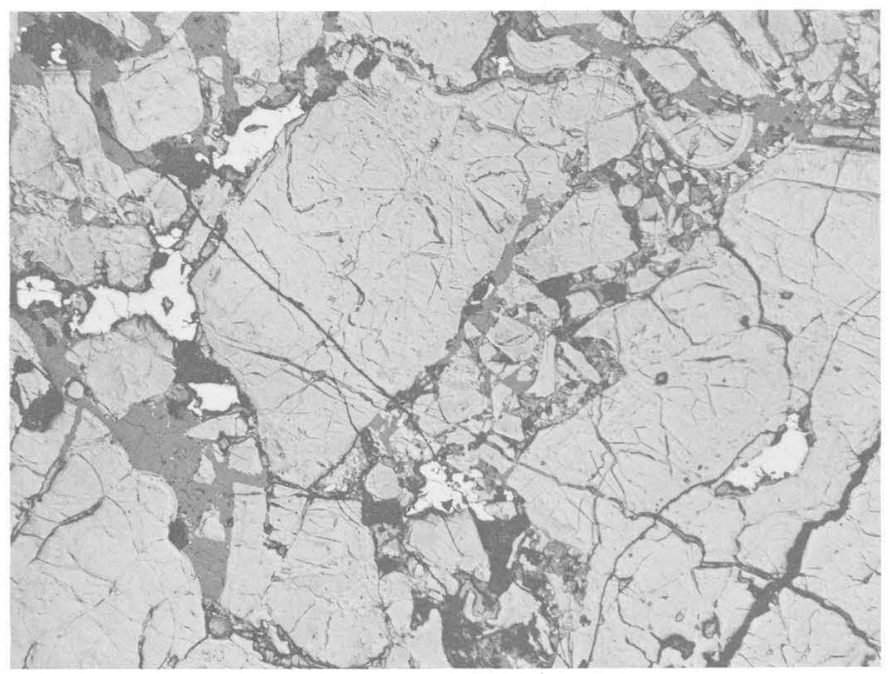

Figure 16.--Photomicrograph showing brecciated pitchblende from the Wood vein, 583-foot level west, East Calhoun mine. The brecciated fragments of massive pitchblende with rotund outer surfaces are partly rotated and recemented by quartz (gray). Pyrite (white) locally embays both quartz and pitchblende. $\times 14$.

quartz (fig. 16), and at places are veined and corroded by later sulfide minerals.

\section{VARIATION IN PHYSICAL APPEARANCE}

Although most of the pitchblende is hard, black, and dense and occurs in well-developed colloform forms as described above, some of it is soft, porous, and locally sooty.

The hard dense pitchblende has a pitchy luster in the hand specimen and gives a black powder. In polished sections it appears homogeneous and is seen to take a 
good polish. The reflectivity of this material is similar to that of sphalerite, and at times, without the advantage of autoradiographs or microchemical tests, it is difficult to distinguish between the two minerals.

The soft porous sooty pitchblende, which gives a greenish-gray or dark-gray powder, is definitely an alteration product of the hard primary mineral, and all gradations exist between the two types. The change from one type to the other can be seen in figures 17 and 18. The first stage in the change (fig. 17), as seen under the microscope, is the alteration of the hard

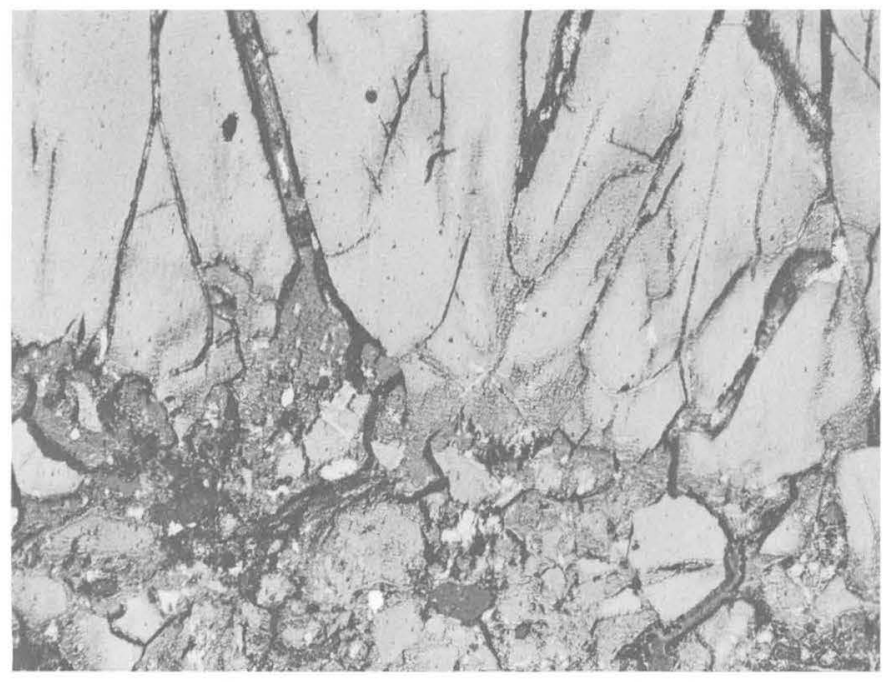

Frgure 17.-Photomierograph of a polished surface of pitchblende ore from the Carroll mine, Central City district. The hard, lustrous pitchblende (light gray) is altered along the main fractures and smaller shrinkage cracks to more porous pitchblende (medium gray). Some sooty pitchblende (black) occurs in vugs and fractures in the lower part of the photograph. $\times 131$.

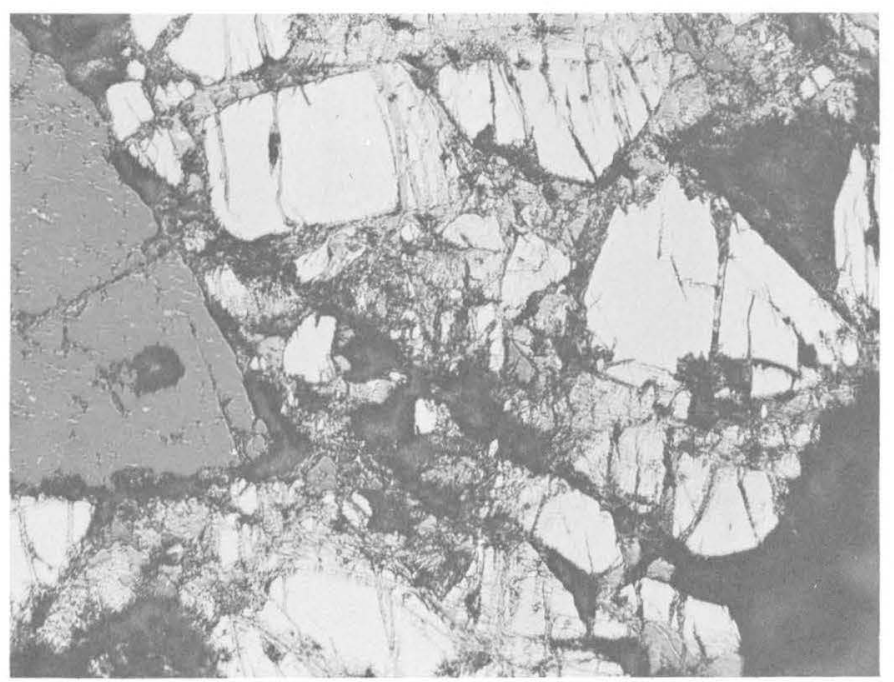

Figure 18.-Photomicrograph of a polished surface of pitchblende ore from the Carroll mine, showing a more advanced stage of alteration than in figure 17. Sooty pitchblende occurs in fractures and vugs throughout the specimen. $\times 131$ dense pitchblende along fractures and margins of the forms to a darker gray, more porous pitchblende which has a much lower reflectivity than the relatively unaltered mineral. As alteration progresses still further, the porosity of the mineral increases, and under the microscope it is seen to take a very poor polish (fig. 18). Ultimately the pitchblende breaks down to a soft sooty loose aggregate which appears opaque under a reflecting microscope. Commonly this material coats mineral grains and vuggy openings in the ore. In figure 18, the vug in the lower right corner is coated by a thin film of sooty material which appears black in the photomicrograph.

\section{VARIATION IN STATE OF OXIDATION}

The change in the physical appearance of the pitchblende from a hard dense mineral to a soft sooty material as a result of weathering is accompanied by a change in the unit-cell dimension of the mineral and a loss of definition of X-ray diffraction powder patterns; according to the data presented by Brooker and Nuffield (1952) these changes are related to oxidation of the pitchblende. During weathering oxygen enters the interstitial positions in the $\mathrm{UO}_{2}$ structure with a consequent change of $\mathrm{U}^{+4}$ to the smaller $\mathrm{U}^{+6}$ ion.

The interpretation that weathering is the dominant factor causing change in the unit-cell dimension of the pitchblende is based on the assumption that all pitchblende is the same age, was deposited in the same oxidation state, contains about the same amounts of other elements that substitute for $\mathrm{U}$ in the $\mathrm{UO}_{2}$ lattice, and, being geologically young, has not had time to undergo susbtantial auto-oxidation. It is known that the unitcell dimension of pitchblende is a function of the oxidation state of uranium at the time of deposition, the amount of auto-oxidation since deposition, and the amount and kind of other elements substituting for $\mathrm{U}$ in the $\mathrm{UO}_{2}$ lattice, as well as the amount of oxidation resulting from weathering.

Except for the pitchblende from the Stanley mine (sample Stan-1, table 12), the pitchblende from the region that has been analyzed by X-ray diffraction methods (table 12) was deposited during the same stage of mineralization (p. 39), and hence is clearly the same age. Also, most pitchblende presumably formed at comparable depths and under similar environmental conditions and hence was deposited in nearly the same oxidation state. It cannot be demonstrated, however, that all sooty pitchblende is seondary; possibly some of it was deposited as primary, fine-grained pitchblende. The pitchblende from the Stanley mine formed after the base-metal stage of mineralization and is later paragenetically than the other 
pitchblende; accordingly, the oxidation state at the time of its deposition relative to that of the other pitchblende is not known. Although quantitative data on the amounts of trace elements are not available to determine accurately the quantities of elements that substitute for $\mathrm{U}$ in the $\mathrm{UO}_{2}$ lattice, sufficient semiquantitative data are available to indicate that most pitchblende contains the same minor elements (table 13). Also, in the absence of information to the contrary, it can be presumed that the pitchblendes contain roughly the same amounts of minor elements, and therefore have about the same amount of distortion in the lattice dimensions. Further quantitative studies are needed on the pitchblendes, however.

The unit-cell dimensions of pitchblende from the region range from 5.461 to $5.400 \mathrm{~A}$ (angstrom units), as shown in table 12. According to the data of Brooker and Nuffield (1952, fig. 22) these dimensions indicate a range in uranium oxidation state from $\mathrm{UO}_{2.03}$ to $\mathrm{UO}_{2.52}$. A few samples of sooty pitchblende from the region gave no powder pattern and, according to the data of Brooker and Nuffield, should contain 85 percent or more of their total uranium as $\mathrm{UO}_{3}$. The $\mathrm{UO}_{2}$-rich pitchblende (table 12) is typically hard, brittle, dense, and has a pitchy luster, but some of it has a dull appearance. It was taken from unaltered veins commonly at depths greater than 150 feet. Although specific gravity determinations were not made, this pitchblende is known to have a high density. Aside from the pitchblende from the Stanley mine (sample Stan-1, table 12), the pitchblende samples with unit-cell dimensions of $5.445 \mathrm{~A}$ or less are moderately soft, and some are crumbly; commonly sooty material is associated with the more dense mineral. All these pitchblende samples were taken from

TABLE 12.-X-ray powder data and uranium oxidation state of pitchblende from the central part of the Front Range mineral belt

\begin{tabular}{|c|c|c|c|c|}
\hline Sample & Mine 1 & $\begin{array}{l}\text { Description of } \\
\text { pitchblende }\end{array}$ & $\begin{array}{c}\text { Unit-cell } \\
\text { dimen- } \\
\text { sion }\left(A_{0}\right)^{2}\end{array}$ & $\begin{array}{l}\text { Uranium } \\
\text { oxidation } \\
\text { state }\end{array}$ \\
\hline W-1(S). & Wood-East & Hard, colloform & 5.461 & $\mathrm{UO}_{2.03}$ \\
\hline $\begin{array}{l}\text { Not numbered. } \\
11-44-A . \\
\text { Not numbered. }\end{array}$ & $\begin{array}{l}\text { Cherokee } \\
\text { Mammoth... } \\
\text { Cherokee.... }\end{array}$ & Moderately haró & $\begin{array}{l}5.459 \\
5.458 \\
5.456\end{array}$ & $\begin{array}{l}\mathrm{UO}_{2,08} \\
\mathrm{UO}_{2,08} \\
\mathrm{UO}_{2,10}\end{array}$ \\
\hline $\begin{array}{l}\text { W-8......... } \\
\text { Not numbered. } \\
\text { Sun-9... } \\
\text { W-4 }\end{array}$ & $\begin{array}{l}\text { Iron } \\
\text { Martha E. } \\
\text { Sunnyside } 8 \\
\text { Name not known. }\end{array}$ & $\begin{array}{l}\text { Soft, porous... } \\
\text { Moderately harc }\end{array}$ & $\begin{array}{l}5.449 \\
5.445 \\
5.437 \\
5.435\end{array}$ & $\begin{array}{l}\mathrm{UO}_{2,15} \\
\mathrm{UO}_{2,18} \\
\mathrm{UO}_{2,24} \\
\mathrm{UO}_{2,26}\end{array}$ \\
\hline $\begin{array}{l}\text { OT-3-1... } \\
\text { B-1- } \\
\text { C-3S-3.-. } \\
\text { Stan-1.... } \\
\text { W-2. }\end{array}$ & $\begin{array}{l}\text { Old Town } \\
\text { Bonanza.......... } \\
\text { Carroll... } \\
\text { Stanley }{ }^{5} \\
\text { Name not known. }\end{array}$ & $\begin{array}{l}\text { Morm. } \\
\text { Moderately soft } \\
\text { Moderately soft, collo- } \\
\text { Moderatorolo }\end{array}$ & $\begin{array}{l}5.435 \\
5.435 \\
5.420 \\
5.416 \\
5.413\end{array}$ & $\begin{array}{l}\mathrm{UO}_{2,28} \\
\mathrm{UO}_{2,20} \\
\mathrm{UO}_{2,38} \\
\mathrm{UO}_{2,40} \\
\mathrm{UO}_{2,43}\end{array}$ \\
\hline W-3. & .....do & - do & 5.400 & $\mathrm{UO}_{2,52}$ \\
\hline
\end{tabular}

1 Except as noted, all mines are in Central City district.

2 X-ray powder patterns by U.S. Geological Survey; analyst: W. F. Outerbridge. Unit-cell measurements by $\mathbf{E}$. W. Tooker.

${ }_{3}$ Calculated from data of Brooker and Nuffield (1952, p. 363-385, fig. 22). 4 Chicago Creek district. partly oxidized veins (near the ground surface) or from mine dumps. Samples W-2 and W-3 (table 12) represent pitchblende taken from mine dumps on Quartz Hill; each was leached considerably by sulfate-rich water that percolated through the dumps. Sample OT3-1 (table 12) came from the seventh level of the Old Town mine; equivalent uranium greatly exceeds uranium in this sample (table 24) as a result of leaching.

\section{CHEMICAI COMPOSITION OF PITCHBLENDE}

Pitchblende from near Black Hawk, Colo.-probably from the Wood or Kirk mines on Quartz Hill-has been analyzed by W. F. Hillebrand (1891, p. 65-66; Clarke, 1903, p. 111; Palache and others, 1944, p. 612). The analysis (average of two analyses) is given below:

Chemical analysis of pitchblende, in percent [Specific gravity of specimens, 8.068]

\begin{tabular}{|c|c|c|c|}
\hline $\mathrm{UO}_{3} \ldots \ldots \ldots$ & 25. 26 & Alkalies......... & $\operatorname{Tr}$ \\
\hline $\mathrm{UO}_{2} \ldots \ldots \ldots$ & 58. 51 & $\mathrm{H}_{2} \mathrm{O} \ldots \ldots$ & 1. 9 \\
\hline $\mathrm{TiO}_{2 \ldots} \ldots \ldots$ & $\operatorname{Tr}$ & Inert gasses $\ldots \ldots$ & \\
\hline $\mathrm{ZrO}_{2 \ldots} \ldots \ldots \ldots$ & 7. 59 & $\mathrm{SiO}_{2} \ldots$ & 2. 7 \\
\hline $\mathrm{CeO}_{2} \ldots \ldots \ldots$ & 22 & $\mathrm{P}_{2} \mathrm{O}_{5} \ldots \ldots$ & \\
\hline $\mathrm{PbO}_{-}$ & 70 & $\mathrm{As}_{2} \mathrm{O}_{5} \ldots \ldots$ & \\
\hline - & .44 & $\mathrm{CuFeS}_{2} \ldots \ldots$ & 1 \\
\hline$\ldots \ldots$ & .32 & $\mathrm{FeS}_{2 \ldots} \ldots \ldots$ & 2 \\
\hline$\ldots-\ldots-\ldots$ & .1 & & \\
\hline $\mathrm{CaO}_{\ldots} \ldots \ldots$ & .84 & 21 & \\
\hline $\mathrm{MgO} \ldots \ldots$ & & & \\
\hline
\end{tabular}

According to Hillebrand (1891, p. 65-66), the pitchblende in the analyzed specimen was massive and intergrown with pyrite and chalcopyrite. These sulfides occurred in minute cracks in the pitchblende and could not be entirely eliminated by hand picking.

\section{MINOR ELEMENTS IN PITCHBIENDE}

The pitchblende contains a limited number of minor elements in addition to its essential elements. Some of the minor elements are consistently present in all samples, whereas others are characteristic of the mineral from a particular geologic environment. The pitchblende that was analyzed for this study was separated by hand-picking under a binocular microscope, and the analyses were made spectrographically using semiquantitative methods. As all the sulfides and gangue were not eliminated from the pitchblende because of their small size and intimate intergrowth with pitchblende, the pitchiblende samples are impure. None of the samples contains more than 18 percent equivalent uranium nor more than about the same quantity of uranium. In interpreting the minor elements, therefore, the writers have attempted to distinguish the mode of occurrence of each reported element.

Semiquantitative spectrographic analysis is a useful technique for determining the minor elements in ores 
and rocks because more than 60 elements commonly can be determined from the photographic record of a single arcing (Waring and Annell, 1953). The intensity of selected lines for each element on the photographic plate is compared visually with prepared standards. The following information concerning the analysis of the pitchblende concentrates given in this report has been furnished by A. T. Myers, who directed the analytical work.

The results of analysis for the elements in the samples are reported in ranges, ench power of ten being divided into three ranges: the ranges are bounded by multiples of the progression 1 , $\sqrt{ } 10, \sqrt{ } 100,10$ (or about $1,2,5,10$ ). The approximate midpoints of the ranges, $1.5,3$, and 7 are the figures used in reporting results, and these figures mean that the amount of an element in a sample may be expected to lie between 1.0 and 2.1, between 2.1 and 4.6, etc. Generally in a series of reported results at least 60 percent are expected to be within the correct range; in these samples, however, the usual sensitivities were not attained because a dilution technique was employed.

The minimum amounts of the elements detectable by the semiquantitative method are shown below:

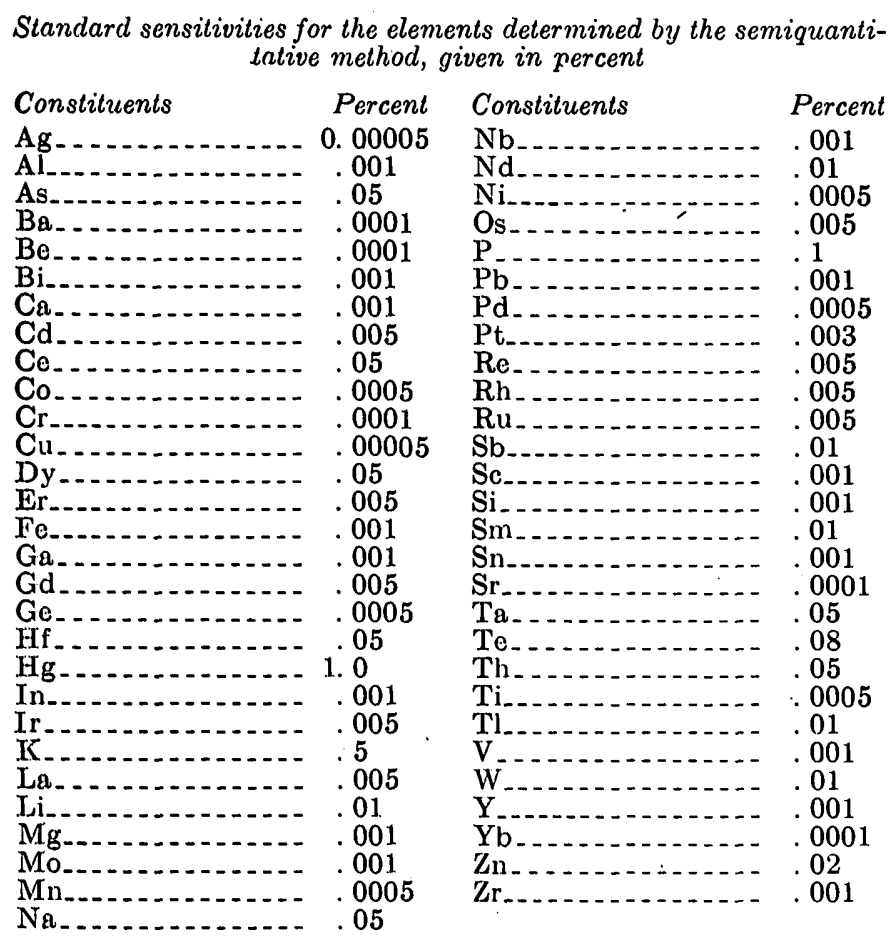

The elements reported in the analyses of pitchblende concentrates (table 13), in addition to uranium, are aluminum, iron, titanium, manganese, silver, arsenic, cobalt, barium, beryllium, chromium, copper, molybdenum, nickel, lead, antimony, scandium, vanadium, tungsten, dysprosium; erbium, yttrium, ytterbium, zinc, and zirconium. Silicon and calcium are present in all the pitchblende concentrate samples and magnesium is present in most, but these elements are not listed in the table. Nearly the entire amounts of the elements iron, titanium, copper, lead, arsenic, antimony, and zinc can be accounted for as inclusions of sulfides, for most polished sections of pitchblende ore show small quantities of the minerals that contain these elements (pyrite, chalcopyrite, galena, tetrahedrite-tennantite, and sphalerite) commonly in shrinkage cracks (figs. 9-12) or as replacements of pitchblende. Some lead can be accounted for as a daughter product resulting from disintegration of the pitchblende. Possibly the minor elements chromium and vanadium occur within the lattice of the sulfides. Manganese, calcium, magnesium, and part of the iron probably are mainly in carbonate inclusions.

The rare-earth metals, yttrium, ytterbium, dysprosium, and erbium, probably are in the pitchblende structure, for these elements are sparse in other ore minerals and ores of the region; yttrium seems to be ubiquitous in pitchblende from all localities.

Most pitchblende samples from the Central City district and a sample from the Jo Reynolds mine in the Lawson area are rich in zirconium and moderately rich in molybdenum and tungsten. The zirconium content generally exceeds 1 percent and in some concentrates it exceeds 5 percent. These high zirconium percentages confirm the high $\mathrm{ZrO}$ values obtained by chemical analyses of pitchblende (Hillebrand, 1891). Although molybdenum is reported locally in minor quantities from veins of other types, the element seems to occur dominantly in pitchblende concentrates. A good correlation exists between molybdenum and uranium in the Wood vein (Drake, 1957). Tungsten may be in the pitchblende structure; generally it correlates with molybdenum.

Cobalt and nickel are present in pitchblende specimens from the Almaden and Golconda mines. These elements occur in inclusions of the nickel arsenides niccolite and pararammelsbergite(?), for as described previously these minerals are locally intergrown with pitchblende (see fig. 22).

The mode of occurrence of the elements that can reasonably be inferred to occur in the pitchblende is not well known. The rare-earth elements and zirconium probably substitute for uranium in the pitchblende structure, for these elements and uranium have similar ionic radii. The molybdenum and tungsten also could occur in the pitchblende structure, but they may be trapped in micro-openings or have been absorbed. 
TABLE 13.-Semiquantitative spectrographic analyses of pitchblende concentrates, Central City and Lawson-Dumont-Fall River districts

[Spectrographic analyses by N. M. Conklin and R. G. Havens. Equivalent-uranium analyses by C. G. Angelo. All samples contain more than 10.0 percent uranium]

\begin{tabular}{|c|c|c|c|c|c|c|c|c|c|c|c|c|c|}
\hline \multirow{2}{*}{ Mine } & \multirow{2}{*}{$\begin{array}{c}\text { Labora- } \\
\text { tory } \\
\text { serial no. }\end{array}$} & \multirow{2}{*}{$\begin{array}{c}\text { Equiva- } \\
\text { lent } \\
\text { uranium } \\
\text { (percent) }\end{array}$} & \multicolumn{11}{|c|}{ Spectrographic analyses (percent) } \\
\hline & & & Al & $\mathrm{Fe}$ & $\mathrm{Ti}$ & $\mathrm{Mn}$ & $\mathrm{Ag}$ & As & Co & $\mathrm{Ba}$ & Be & $\mathrm{Cr}$ & $\mathrm{Cu}$ \\
\hline 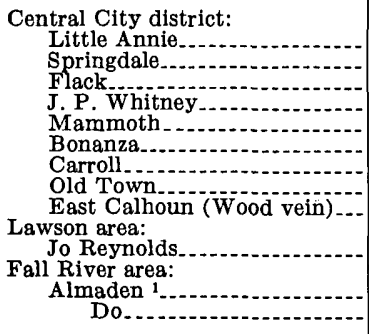 & $\begin{array}{l}228095 \\
228096 \\
228097 \\
228098 \\
228099 \\
228100 \\
228101 \\
228105 \\
228106 \\
229103 \\
224640 \\
208216\end{array}$ & $\begin{array}{r}17.0 \\
18.0 \\
13.0 \\
17.0 \\
17.0 \\
9.0 \\
11.0 \\
18.0 \\
13.0 \\
\text { n.d. } \\
\text { n.d. } \\
\text { n.d. }\end{array}$ & $\begin{array}{l}0.7 \\
.07 \\
1.5 \\
.03 \\
.3 \\
3.0 \\
.03 \\
.03 \\
.03 \\
1.5 \\
.07 \\
0\end{array}$ & $\begin{array}{r}7.0 \\
7.0 \\
>10.0 \\
.7 \\
1.5 \\
>10.0 \\
.3 \\
.7 \\
.3 \\
.7 \\
.7 \\
3.0 \\
.7\end{array}$ & $\begin{array}{l}0.15 \\
.3 \\
.15 \\
.15 \\
.3 \\
1.5 \\
.3 \\
.15 \\
.7 \\
.15 \\
\text { n.d. } \\
0\end{array}$ & $\begin{array}{l}0.15 \\
.03 \\
.07 \\
.15 \\
.003 \\
.0015 \\
.07 \\
.003 \\
.15 \\
.15 \\
. .7\end{array}$ & $\begin{array}{l}0.007 \\
.003 \\
.007 \\
.07 \\
.007 \\
0.015 \\
.015 \\
0 \\
.3 \\
7.0 \\
0\end{array}$ & $\begin{array}{c}0 \\
0 \\
0 \\
0 \\
0 \\
0 \\
0 \\
0 \\
0 \\
0 \\
>10.0 \\
0\end{array}$ & $\begin{array}{l}0 \\
0 \\
0 \\
0 \\
0 \\
0 \\
0 \\
0 \\
0 \\
0 \\
\quad .07 \\
\end{array}$ & $\begin{array}{l}0.03 \\
0 \\
.015 \\
.03 \\
.03 \\
0.015 \\
.03 \\
.015 \\
.15 \\
\text { n.d. }\end{array}$ & $\begin{array}{l}0 \\
0 \\
0 \\
0 \\
0 \\
.003 \\
.003 \\
0^{.0007} \\
0^{\text {n.d. }}\end{array}$ & 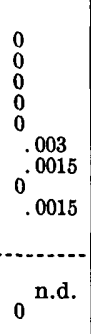 & \begin{tabular}{c}
0.3 \\
.03 \\
.03 \\
.07 \\
.07 \\
.07 \\
.07 \\
.07 \\
\hdashline.- \\
.3 \\
.3 \\
.015
\end{tabular} \\
\hline \multirow{2}{*}{ Mine } & \multicolumn{13}{|c|}{ Spectrographic analyses (percent) } \\
\hline & Mo & $\mathrm{Ni}$ & $\mathrm{Pb}$ & $\mathrm{Sb}$ & Sc & $\mathbf{V}$ & $\mathbf{w}$ & Dy & $\mathbf{E r}$ & $\mathbf{Y}$ & $\mathbf{Y b}$ & $\mathrm{Zn}$ & $\mathrm{Zr}$ \\
\hline $\begin{array}{l}\text { Central City district: } \\
\text { Little Annie. } \\
\text { Springdale... } \\
\text { Flack } \\
\text { J. P. Whitney } \\
\text { Mammoth } \\
\text { Bonanza } \\
\text { Carroll } \\
\text { Old Town } \\
\text { East Calhoun (Wood vein) } \\
\text { Lawson area: } \\
\text { Jo Reynolds } \\
\text { Fall River area: } \\
\text { Almaden }{ }^{1} \\
\text { Do }{ }^{1}\end{array}$ & $\begin{array}{l}0 \\
0 \\
.03 \\
.3 \\
0 \\
0 \\
.15 \\
.15 \\
0 \\
.03 \\
.0 \\
.07\end{array}$ & $\begin{array}{l}0 \\
0 \\
0 \\
0 \\
0 \\
0 \\
0 \\
0 \\
3.0 \\
.7\end{array}$ & $\begin{array}{l}0.7 \\
.15 \\
.3 \\
3.0 \\
.15 \\
.7 \\
.3 \\
.15 \\
.15 \\
3.0 \\
3.0 \\
0\end{array}$ & $\begin{array}{l}0 \\
0 \\
0 \\
0 \\
0 \\
0 \\
0 \\
0 \\
0 \\
0 \\
. \\
0 \\
0\end{array}$ & $\begin{array}{l}0 \\
0 \\
0 \\
0 \\
0 \\
.03 \\
0 \\
0 \\
0 \\
0 \\
\text { n.d. } \\
0\end{array}$ & $\begin{array}{l}0 \\
0 \\
0 \\
0 \\
0 \\
.015 \\
0 \\
0 \\
0 \\
0 \\
0 \\
0\end{array}$ & $\begin{array}{l}0 \\
.3 \\
.3 \\
.7 \\
0 \\
0 \\
.7 \\
.7 \\
.3 \\
1.5 \\
0 \\
0\end{array}$ & $\begin{array}{l}0 \\
0 \\
0 \\
0 \\
0 \\
0 \\
0 \\
0 \\
0 \\
0 \\
0 \\
0 \\
.15\end{array}$ & $\begin{array}{l}0 \\
0 \\
0 \\
0 \\
0 \\
0 \\
0 \\
0 \\
0 \\
0 \\
0 \\
.15 \\
0\end{array}$ & $\begin{array}{l}0.15 \\
.3 \\
.07 \\
.07 \\
.3 \\
.3 \\
.15 \\
.15 \\
.15 \\
.03 \\
.7 \\
.03\end{array}$ & 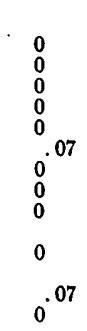 & $\begin{array}{l}1.5 \\
0 \\
.7 \\
3.0 \\
0 \\
.7 \\
1.5 \\
0 \\
0 \\
0 \\
1.5 \\
.7\end{array}$ & $\begin{array}{l}7.0 \\
3.0 \\
.7 \\
3.0 \\
3 . \\
1.5 \\
1.5 \\
3.5 \\
1.5 \\
1.5 \\
0.03\end{array}$ \\
\hline
\end{tabular}

TORBERNITE AND METATORBERNITE

$$
\mathrm{Cu}\left(\mathrm{UO}_{2}\right)_{2}\left(\mathrm{PO}_{4}\right)_{2} \cdot 8-12 \mathrm{H}_{2} \mathrm{O}
$$

Torbernite and metatorbernite were observed in the upper parts of several uranium-bearing veins and on the dumps of a few mines. They are the most abundant secondary uranium minerals in the region and, judging from $\mathrm{X}$-ray determinations, metatorbernite is the more common of the two minerals. Characteristically the minerals are concentrated along fractures in altered wallrocks within 10 feet of a vein or in oxidized vein material, but locally they are disseminated through certain types of altered wallrocks (Sims, Osterwald, and Tooker, 1955, p. 17-18) or clayey gouge. At the Carroll mine, torbernite locally coats partly leached pitchblende. Torbernite also is an alteration mineral of the uraninitebearing pegmatites in Virginia Canyon, where the mineral forms at the surface in close association with autunite.

\section{AUTUNITE AND META-AUTUNITE}

$\mathrm{Ca}\left(\mathrm{UO}_{2}\right)_{2}\left(\mathrm{PO}_{4}\right)_{2} \cdot 10-12 \mathrm{H}_{2} \mathrm{O}$

Autunite and meta-autunite are sparse in the veins. Autunite was observed at the Martha E mine, and metaautunite was found at the Star mine in Spring Gulch, the Sunnyside mine, and the Blackhawk Lode No. 2 claim. Autunite, however, is a common mineral in the oxidized parts of the uraninite-bearing pegmatites where it is closely associated with torbernite. The autunite ranges from lemon-yellow to pale green in color, has a strong yellow-green fluorescence, and is vitreous to pearly. It occurs as thin tabular crystals that generally form scaly aggregates on fracture surfaces.

\section{KASOLITE}

\section{$\mathrm{Pb}\left(\mathrm{UO}_{2}\right) \mathrm{SiO}_{4}: \mathrm{H}_{2} \mathrm{O}$}

Kasolite, associated with hydrous iron oxides, is present in the oxidized parts of uranium-bearing galena-sphalerite veins. It is particularly abundant at the Two Sisters mine and the Blackhawk Lode No. 2 claim. The kasolite occurs as thin mats of yellowbrown fibers and tabular crystals often in rosettes or sheaflike aggregates that coat vugs in oxidized limonitic vein material.

\section{DUMONTITE}

$$
\mathrm{Pb}_{2}\left(\mathrm{UO}_{2}\right)_{3}\left(\mathrm{PO}_{4}\right)_{2}(\mathrm{OH})_{4} \cdot 3 \mathrm{H}_{2} \mathrm{O}
$$

Dumontite was identified by $\mathbf{X}$-ray analysis by W. F. Outerbridge of the Geological Survey from dump ma- 
terial at the Ariadne mine. It occurs as thin coatings on fractures in biotite-muscovite granite.

\section{URANOPHANE}

$\mathrm{Ca}\left(\mathrm{UO}_{2}\right)_{2} \mathrm{SiO}_{7} \cdot 6 \mathrm{H}_{2} \mathrm{O}$

Uranophane is abundant in the near-surface parts of some uraninite-bearing pegmatites in Virginia Canyon and occurs at the Star mine in Spring Gulch. In the pegmatites it forms minute yellow or orangeyellow prismatic crystals in radiating aggregates on fracture surfaces in the pegmatite. At places it is closely associated with autunite, commonly occurring slightly farther below the ground surface than autunite. At the Star mine, uranophane together with metatorbernite, meta-autunite, and wad(?) occurs along fractures in granite gneiss and pegmatite wallrocks near the vein.

$$
\begin{gathered}
\text { BAYLEYITE } \\
\mathrm{Mg}_{2}\left(\mathrm{UO}_{2}\right)\left(\mathrm{CO}_{3}\right)_{3} \cdot 18 \mathrm{H}_{2} \mathrm{O}
\end{gathered}
$$

Bayleyite, a vitreous sulfur-yellow mineral, coats fracture surfaces in uraninite-bearing pegmatite at the New Bedford mine in the Idaho Springs district. It clearly formed after mining had begun and presumably formed by the alteration of the uraninite.

\section{ZIPPEITE AND BETAZIPPEITE}

$$
\left(\mathrm{UO}_{2}\right)_{2}\left(\mathrm{SO}_{4}\right)(\mathrm{OH})_{2} \cdot 4 \mathrm{H}_{2} \mathrm{O}
$$

Zippeite has been identified by X-ray determinations from the Diamond Joe and Remington mines, and betazippeite has been noted at the Alma-Lincoln mine. The minerals occur as encrustations on the mine walls at the Diamond Joe and Remington mines, and seem to be derived from the alteration of quartz bostonite porphyry and uranium-bearing pegmatite, respectively. On level 3 at the Alma-Lincoln mine the betazippeite coats slickensided surfaces in gouge along both the hanging wall and footwall of the vein.

\section{SHROECKINGERITE}

$$
\mathrm{NaCa}_{3}\left(\mathrm{UO}_{2}\right)\left(\mathrm{CO}_{3}\right)_{3}\left(\mathrm{SO}_{4}\right) \mathrm{F} \cdot 10 \mathrm{H}_{2} \mathrm{O}
$$

Shroeckingerite has been identified from level 2 of the Alma-Lincoln mine. It occurs as rosettes scattered on the mine walls adjacent to a radioactive vein. It definitely formed after development of the mine.

\section{THUCHOLITE(?)}

A few grains of a dull black, radioactive material that has a conchoidal fracture oceur in gouge that was formed later than the ore in association with zippeite at the Alma-Lincoln mine. The material has a specific gravity of 1.91 to 1.93 and gives a sharp X-ray pattern similar to that of sphalerite.

\section{JOHANNITE}

$\mathrm{Cu}\left(\mathrm{UO}_{2}\right)_{2}\left(\mathrm{SO}_{4}\right)_{2}(\mathrm{OH})_{2} \cdot 6 \mathrm{H}_{2} \mathrm{O}$

Johannite, associated with zippeite and gypsum, has been reported from Quartz Hill (Palache and others, 1951 , p. 599, 607), but the locality from which it was identified is not known.

\section{PARAGENETIC RELATIONS OF PITCHBLENDE TO}

\section{THE COIMIION VEIN-FORMING MINERALS}

Pitchblende was deposited early in the sequence of vein filling, contemporaneously with quartz and an early generation of pyrite, and, excepting the secondary pitchblende, entirely before the deposition of the basemetal sulfides and sulfosalts. An exception is pitchblende at the Stanley mine, Idaho Springs district, which formed late in the sequence of mineralization.

At Central City, pitchblende clearly was deposited during an early separate stage of mineralization that preceded the pyrite stage of mineralization (Sims, $1956 \mathrm{a}$, p. 745-747). It was precipitated with quartz and sparse pyrite, in stringers and other vein forms, as described on pages 32-34. After its deposition, and prior to pyrite mineralization, the pitchblende stringers were locally fractured by recurrent movements along the vein fissures. Accordingly, except for stringers in the walls of the main veins that remained unfractured (fig. 19), the pitchblende-bearing veinlets were commonly broken and brecciated, and at places veined by later sulfide minerals. Brecciated pitchblende that is veined by chalcopyrite and pyrite is shown in figure 20, a photograph of a typical specimen of ore from the Wood vein. A photomicrograph of another specimen of pitchblende ore from an adjacent vein, the Kirk, shows brecciation

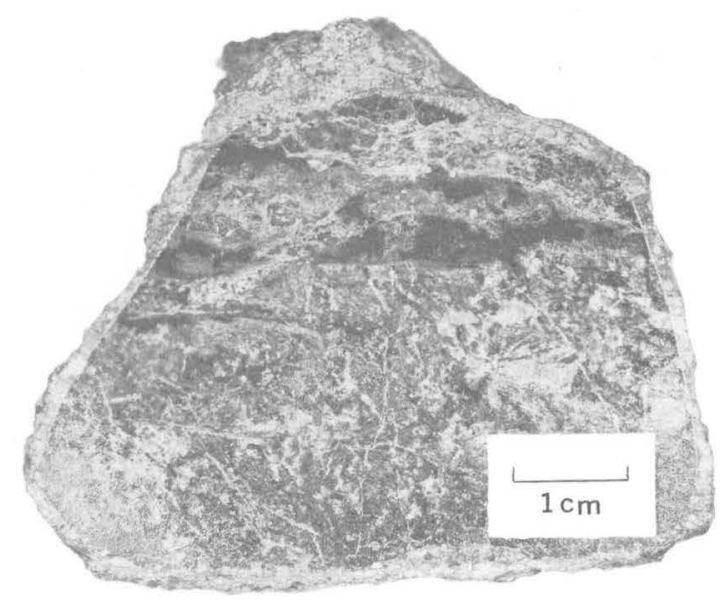

Figure 19.-Photograph of a polished surface of pitchblende ore, Carroll mine, Central City district. The pitchblende (black) occurs as discontinuous stringers in relatively fresh microcline-bearing gneiss wall rock. The specimen was taken from the wall of the main galena-sphalerite vein. 


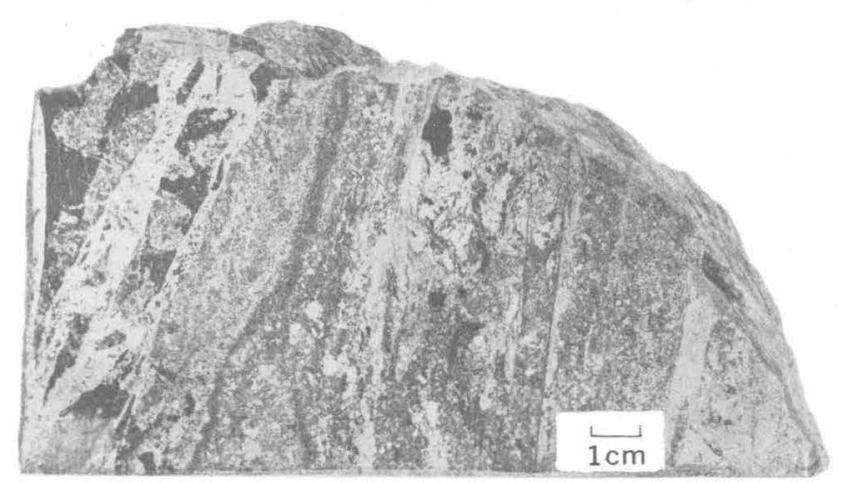

Figure 20.-Photograph of a polished surface of ore from the Wood vein, 583-foot level west, East Calhoun mine, Central City district. The pitchblende (black) was breceiated, recemented by quartz, and veined by pyrite and chalcopyrite.

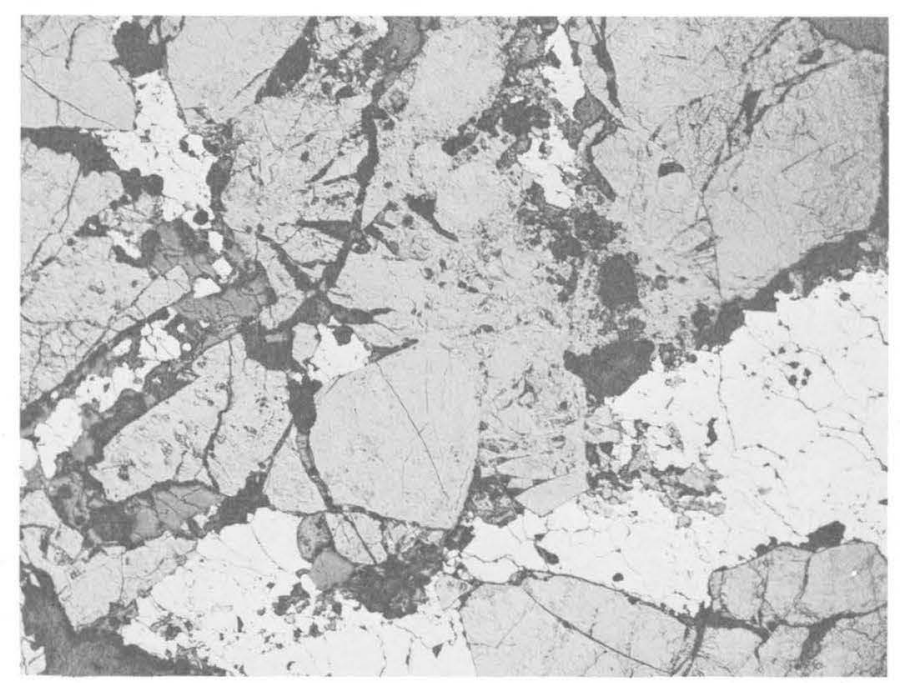

Figure 21.-Photomicrograph of brecciated pitchblende from the Kirk mine, Central City district. The brecciated fragments are partly rotated and recemented by quartz (dark gray). The quartz and locally the pitchblende are embayed and partly replaced by pyrite (white). $\times$ 14. Specimen loaned by R. R. Hinckley.

and veining in more detail (fig. 21). In this specimen the broken pitchblende is cemented by quartz and veined by quartz and pyrite. At many places galena or other base-metal sulfides or sulfosalts occur in the fractures within the pitchblende and, to a minor extent, embay the pitchblende (figs. 9-16).

At the Jo Reynolds mine, in the Lawson-Dumont-Fall River district, and at the Sunnyside mine, in the Idaho Springs district, pitchblende also was deposited before the base-metal sulfides, principally with quartz and sparse pyrite.

In the Fall River area, pitchblende was deposited early in the sequence of vein filling, but apparently as a local variant of the main pyritic mineralization rather than as a separate distinctly older stage. At the Almaden mine, niccolite and pararammelsbergite(?) are

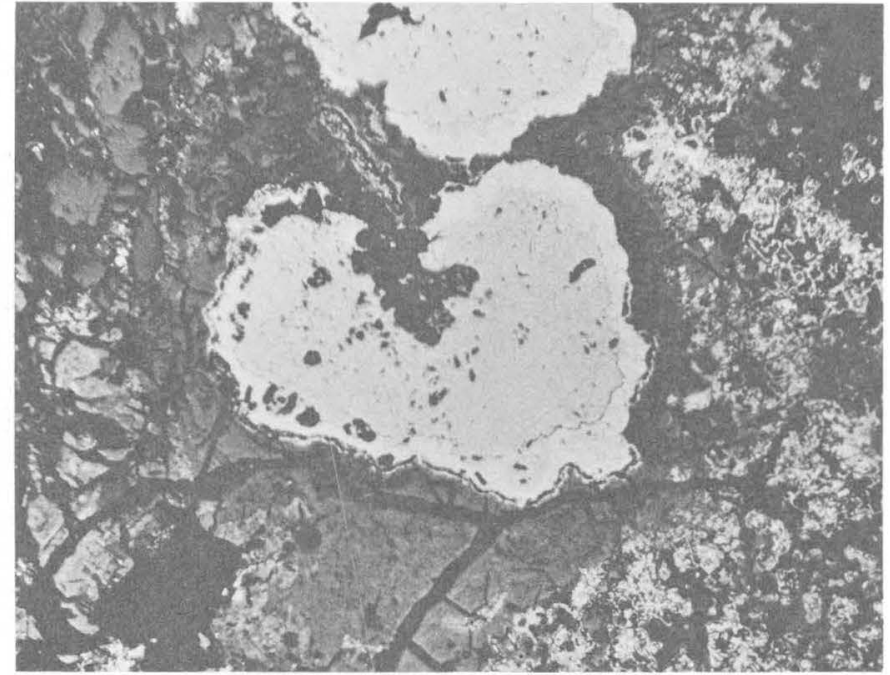

FIGURE 22.--Photomicrograph of polished surface of pitchblende ore from the Almanden mine, Fall River area. Subrounded grains of niccolite (gray) with narrow rims of pararammelsbergite(?) are enclosed by pitchblende (dark gray). The cellular or dendritic forms to the right are freibergite. $\times 50$.

closely associated with pitchblende in the same stringers (fig. 22). Pitchblende was deposited both before and after the niccolite; pararammelsbergite(?) is later than both the pitchblende and the niccolite. At the Mary mine, both pyrite and marcasite were deposited before pitchblende.

At the Stanley mine, in the Idaho Springs district, pitchblende was precipitated locally as colloform coatings on finely colloform pyrite, which in turn were deposited on gray quartz, galena, and pyrite. The pitchblende-bearing stringer cuts across and is later than the main sulfide vein.

Sooty pitchblende at all localities appears to have formed late in the paragenetic sequence for it occurs in vugs and fractures which at places crosscut the sulfide ore minerals. Probably this type of pitchblende has been redistributed by ground water subsequent to its original formation; accordingly it has a mode of occurrence typical of known supergene minerals.

The conclusions presented above for the Central City district differ somewhat from those of Bastin (Bastin and Hill, 1917, p. 123-124), who concluded from a study of a few polished sections from pitchblende-bearing veins on Quartz Hill that pitchblende crystallized contemporaneously with pyrite, chalcopyrite, and gray quartz (Bastin and Hill, 1917, figs. 11 and 12, p. 123124) but was older than the other sulfides and sulfosalts. The present writers concur that some pyrite and quartz were formed virtually contemporaneously with pitchblende, as described previously, but have observed no evidence of simultaneous deposition of chalcopyrite and pitchblende. Instead, the textures seen in polished 
sections clearly indicate that the chalcopyrite is entirely later than the pitchblende and most of the pyrite. The writers interpret the textural relations between pitchblende and chalcopyrite observed by Bastin-chalcopyrite occuring both inside and outside of spheroidal pitchblende forms (Bastin and Hill, 1917, fig. 12, p. 124) - to have resulted from replacement of quartz by chalcopyrite, although some of the chalcopyrite could have encrusted underlying rounded surfaces and filled shrinkage cracks.

\section{GENERAL CHARACTER AND STRUCTURE}

Pitchblende and at places its alteration products occur in vein fissures of all fracture sets as small lenses, pods, and stringers, or rarely as larger ore shoots.

\section{RELATION OF DEPOSITS TO FAULT SETS}

Uranium deposits occur in all the fault sets of the region, but are more abundant in the faults of Laramide age. At places they are in subsidiary fractures in the walls of the main faults or at the junction of two faults.

About 70 percent of the significant uranium-bearing veins (see table 8) strike east-northeast or northeast, 10 percent strike east, 15 percent strike northwest, and less than 5 percent are low-angle northward-dipping veins. No deposits of this class occur in north-northeastwardtrending faults. The deposits of lesser importance (tables 10 and 11) occur in the different fracture sets in about the same ratio; a few of these are in north-northeastward-trending fractures.

As can be seen by comparing plate 1 and tables 9 , 10 , and 11, the occurrence of uranium deposits in the different fracture sets is roughly proportional to the abundance of faults of each set. The deposits are most abundant in the fault sets consisting of the greatest number of fractures.

In the areas containing clusters of uranium deposits (compare pls. 1 and 3), uranium commonly occurs along faults belonging to 2 or more of the fracture sets, although deposits may be more abundant in 1 particular set; locally it occurs at the junction or intersection of 2 faults. In the Quartz Hill area (compare pls. 1 and 3 ), for example, significant uranium deposits are in northwestward-trending, eastward-trending, eastnortheastward-trending; and northeastward-trending faults. Most of the deposits, however, and all but one of the productive deposits are in east-northeastwardtrending faults.

In the Chicago Creek area, radioactivity typically occurs in one of several subparallel veins; the others are commonly barren of uranium.

\section{ORE SHOOTS}

The pitchblende is not regularly distributed through the veins, but instead occurs as small lenses, pods, and stringers, or more rarely as larger bodies that are properly termed "ore shoots." The margins of the ore bodies are sharp, and the vein material between the bodies commonly is nearly devoid of uranium. The small pods or lenses contain only a few tens or hundreds of pounds of uranium ore, whereas the larger known shoots contain as much as 50 tons of ore.

Small bodies of pitchblende ore occur locally along many veins in the region, but most abundantly in the Central City district. At places the pitchblende is in the main veins, associated with the precious metal-bearing sulfide ores, and at other places it is in minor subsidiary fractures in the walls of the main veins, adjacent to but not closely associated with the sulfide ore minerals.

The pitchblende deposits in the Quartz Hill and upper Russell Gulch areas of the Central City district, and at most other places in the region, consist almost entirely of small pods and lenses of high-grade pitchblende ore that are distributed erratically along the veins; a few appear to occur systematically in the veins within what the writers refer to as "zones of ore shoots." At the Kirk, Wood, and German-Belcher mines the pitchblende ore that was mined occurred mainly as pods and lenses adjacent to the country rock on the hanging wall or footwall of the veins; some was in small discontinuous veinlets in the wallrocks. At the Kirk mine some pods were as much as 1 foot thick, and one described by Moore and Kithil (1913, p. 44) measured 2 feet 8 inches by 1 foot 4 inches by 1 foot. At the Wood mine, the pitchblende ore had a similar mode of occurrence. Bastin and Hill (1917, p. 245) state that the pitchblende formed small discontinuous lenses and streaks on the footwall of the vein, which were separated by barren vein material. Single bodies contained from a few pounds to about 5 tons of ore. The recent exploration of the Wood vein at greater depth-from the 583 level of the East Calhoun mine (Drake, 1957)disclosed two lenses of ore, the larger about 10 feet long, 8 feet high, and an average of less than 6 inches thick. The two lenses yielded about 17 tons of ore. The deposits within the Wood vein occur within a downwardtapering zone of ore shoots that plunges steeply west (Moore and Butler, 1952, pl. 1; Drake, 1957, fig. 34).

At the German-Belcher mine, the pitchblende ore that was mined occurred dominantly as small lenses that contained from a few pounds to a few hundred pounds of ore (Bastin and Hill, 1917, p. 241); some pitchblende is in 1-inch-thick discontinuous veinlets in 


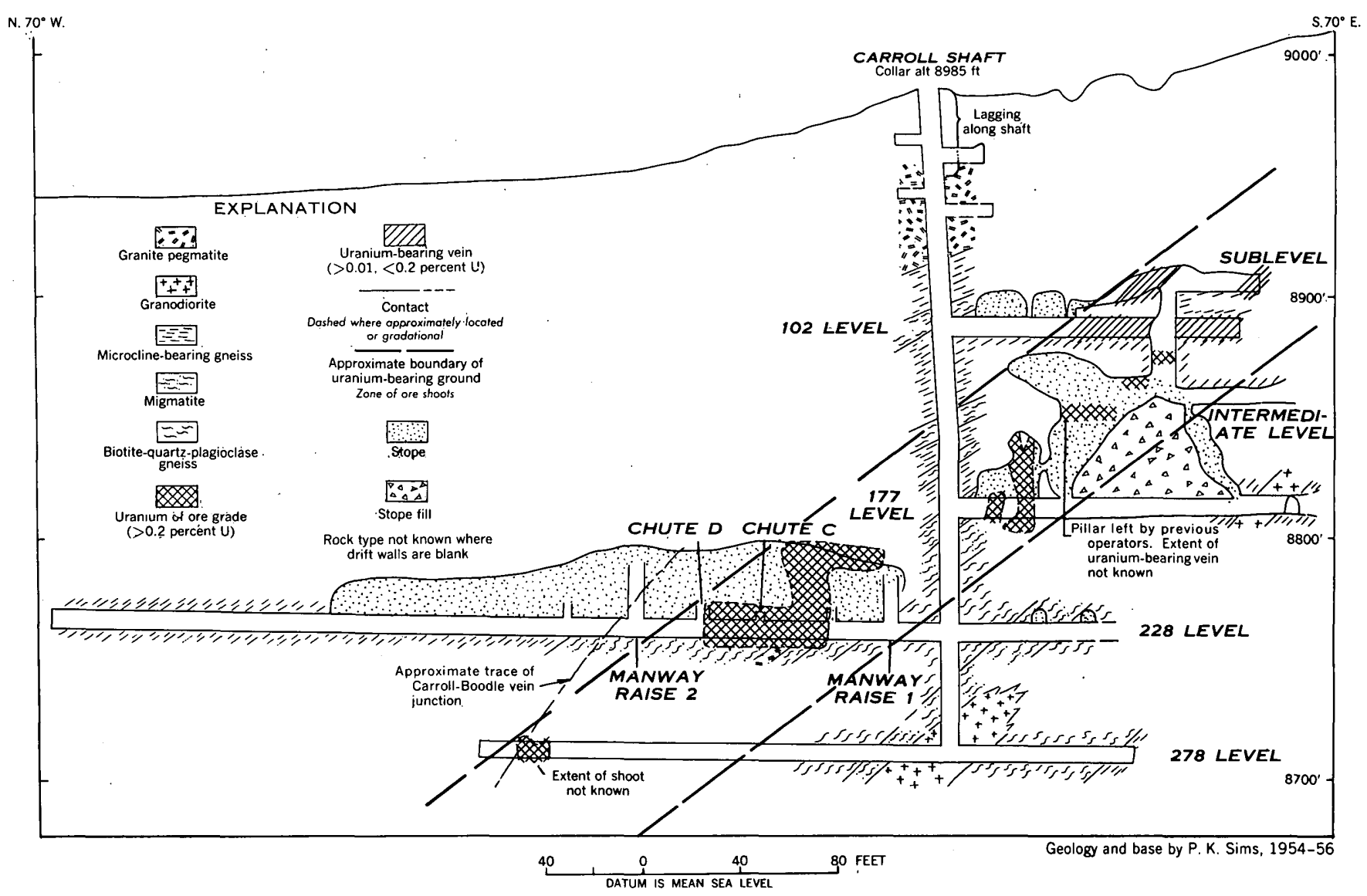

Figdre 23.- Vertical longitudinal projection of the Carroll mine, showing relation of zone of urantum ore shoots to Precambrian wallrocks.

the walls of the main vein. Similar small lenses of pitchblende ore have been found in the Denbigh and Gold Rock veins at the Springdale mine, in the Blazing Star vein at the Almaden mine, and in other veins.

At places pitchblende-bearing ore occurs in subsidiary fractures in the walls of the main sulfide-bearing veins but is not present in the main veins. An example of this type of occurrence is the Old Town mine in Russell Gulch. At this mine, pitchblende occurs locally on three levels as short $1 / 4$-inch veinlets in silicified wallrock adjacent to the Old Town vein. The known occurrences are in small fractures in the footwall of the vein, which have the appearance of gash or tension fractures.

Rarely the pitchblende is in shoots that have maximum dimensions of several tens of feet and contain several tons of ore, for example in the Carroll mine on Nigger Hill (Sims, 1956a, p. 751-753). The uranium ore shoots in the Carroll vein are arranged en echelon within a westward-plunging zone of favorable ground of zone of ore shoots (fig. 23). The largest known ore shoot, on the 228 level, has a height of about 50 feet, a stope length of as much as 50 feet, and an average width of about 6 inches. A smaller shoot, with a maximum horizontal length of only about 11 feet, was mined on the 177 level. Remnants of ore left in pillars and drifts in the upper mine workings east of the shaft probably represent parts of other small shoots in this part of the vein.

The pitchblende within the shoots of the Carroll vein is in discontinuous stringers and pods or in tabular layers. The ore within the shoot on the 177 level (fig. 23) occurred mainly as a tabular layer that was 1 to 4 inches thick and as much as 11 feet wide. The ore layer was about 6 inches above the vein footwall and separated from it by radioactive gouge. In the lower part of the shoot, mined in the small underhand stope, a pod or kidney of ore occurred at the junction of two 1-inch-thick pitchblende-bearing veinlets. The pod was 12 inches wide and plunged $18^{\circ} \mathrm{N} .60^{\circ} \mathrm{W}$. The ore within the shoot on the 228 level was mainly a tabular layer of varying thickness, but the ore occurred partly as pods at the junction of veinlets and as crosscutting stringers. Figure 24, a map of the pitchblende-bearing vein on the 228 level, shows in detail the pitchblende occurrences and their relation to the galena-sphalerite vein. The pitchblende near chute $\mathrm{C}$ was on the hang- 


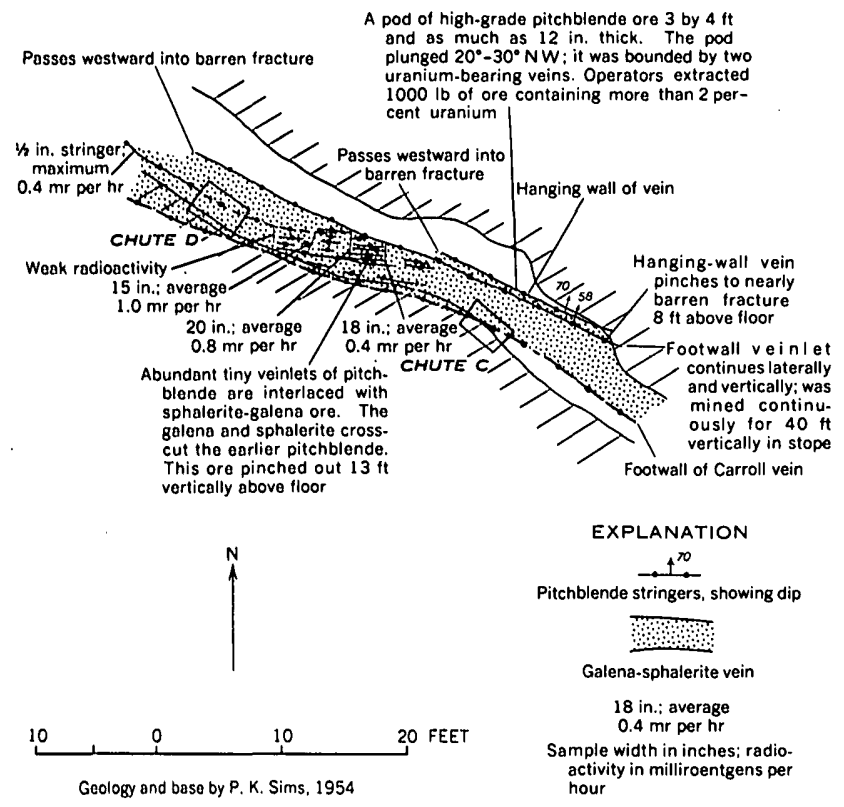

Fraore 24.-Detalled geologic map showing pitchblende-bearing ore near chute $C$, (see pl, 7) Carroll veln, 228 level west.

ing (north) wall of the vein in two closely spaced veinlets. The outermost veinlet, which formed the hanging wall of the vein, pitched out within a short distance both laterally and vertically. The inner veinlet was more continuous and extended as a tabular body to the top of the stope, where it pinched out. In the drift the veinlet was 1 to 3 inches thick, but it was wider in the stope, averaging about 6 inches thick, and at one place it was as much as 15 inches thick. Locally on the 228 level, steep cross fractures between the two veinlets which converge slightly near the floor also contained small stringers of pitchblende, the whole locally constituting ore (see Sims, 1956a, fig. 8). A pod of pitchblende ore, 3 feet by 4 feet by 1 foot, which occurred at the junction of the two veinlets, was mined opposite chute $\mathrm{C}$ (fig. 23). This pod plunged $20^{\circ}-30^{\circ} \mathrm{NW}$., in the same direction as the pod mined on the 177 level. Between chutes $\mathrm{C}$ and $\mathrm{D}$ on the 228 level (fig. 24) the pitchblende occurred in many 1-inch-thick stringers that trended at an acute angle to the strike of the Carroll vein. This zone, which was as much as 15 inches wide, pinched out about 5 feet above the back of the drift. The stringers were cut, broken, and locally obliterated by the later galena-sphalerite ore that constitutes the bulk of the Carroll vein.

\section{GRADE OF PRIMARY DEPOSITS}

As the pitchblende in the primary deposits occurs as small high-grade stringers and pods that are much too narrow to be mined profitably, the grade of the ship- ping ore is variable and depends largely on the care taken in mining and sorting. Most of the ore that has been shipped was selectively mined, commonly by resuing, and was upgraded by hand-sorting. Recently, attempts have been made to upgrade some of the uranium ores intimately associated with the sulfide ores by milling techniques.

The primary uranium ores that were shipped before 1950 were high grade, commonly exceeding 10 percent uranium, but recent shipments have been of a much lower grade. The ore that was shipped from Quartz Hill was mined principally from small rich pods and lenses of pitchblende. Calculations of the grade of the ore shipped from the Wood and Kirk mines (table 1) indicate that a substantial proportion of this ore contained more than 50 percent uranium, and ore of this tenor accounted for a large proportion of the production from the region. Other ore that was shipped contained from 1 to 5 percent uranium. Undoubtedly this material largely represented the ore that could not be greatly upgraded by hand-sorting.

The grade and the erratic distribution of uranium within a lens of pitchblende-bearing ore from Quartz Hill can be inferred from figure 25, an assay map of part of the Wood vein on the 583 level of the East Calhoun mine. The pitchblende, which is associated with pyrite, chalcopyrite, and rarely tetrahedrite-tennantite, is erratically distributed in the lens, not only horizontally along the strike of the lens but also vertically. Analyses across the lens indicate that the uranium content ranges from 0.01 to 9.94 percent. A photograph of a specimen taken from the lens (fig. 20) shows the
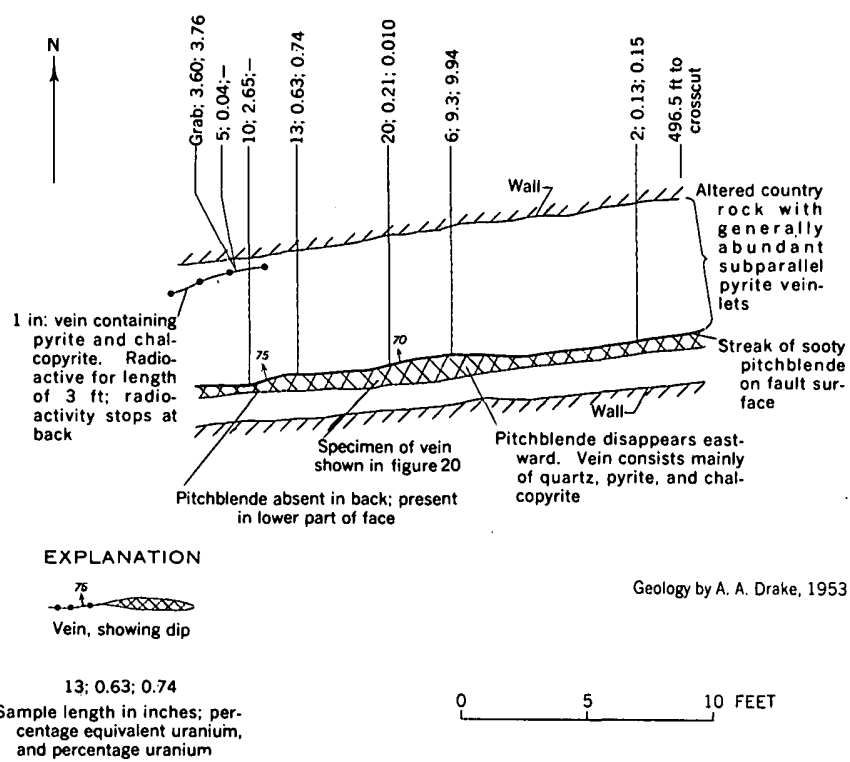
centage equivalent uranium

Figdre 25.-Assay map of pitchblende-bearing lens, Wood veln, 583 level west, East Calhoun mine. 


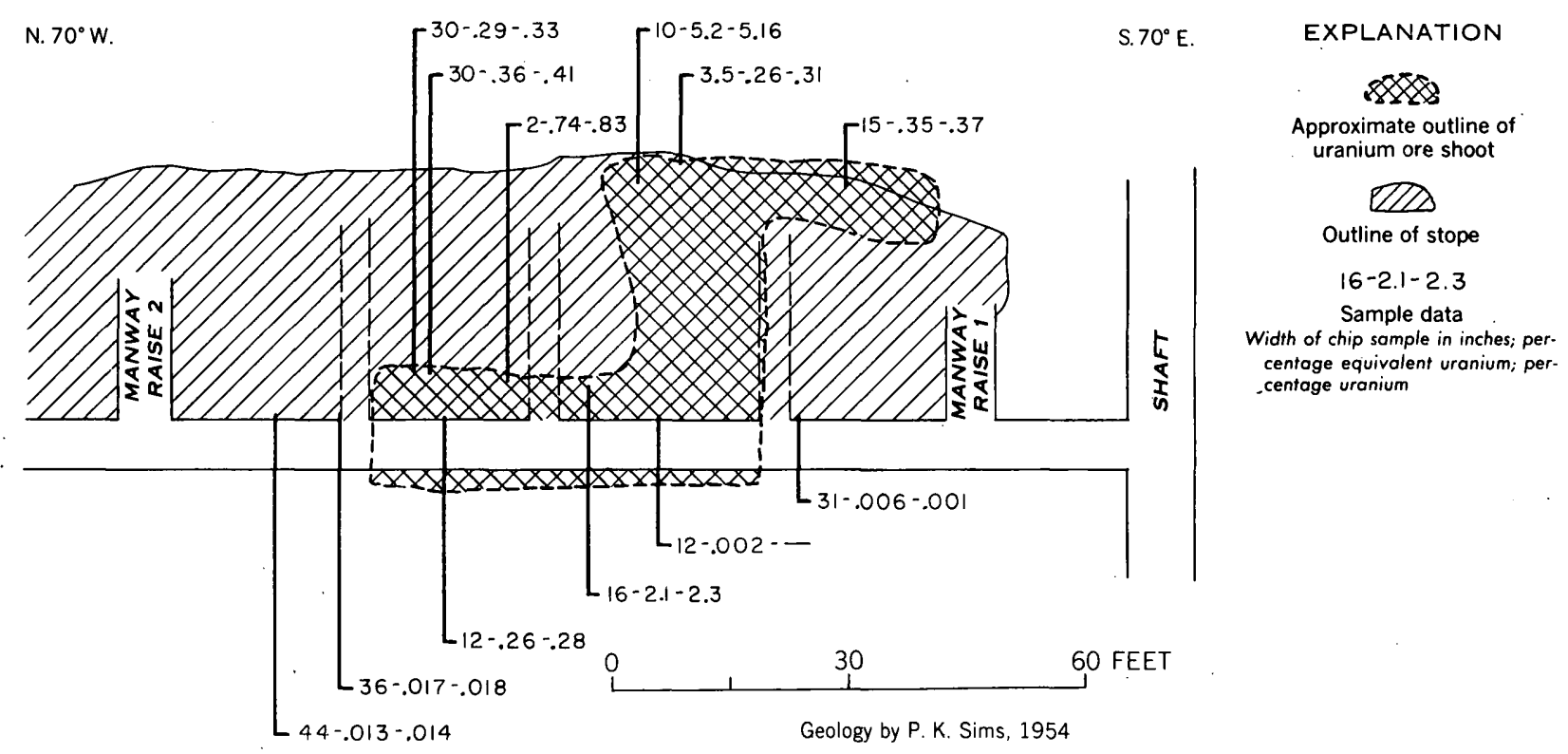

Figure 26.-Assay section of part of stope on the 228 level west, Carroll mine, showing uranium analyses.

character of the pitchblende and its relation to the sulfides.

The grade of the ore within the pitchblende ore shoots at the Carroll mine varies widely. Uranium analyses from the largest of the shoots, which was mapped in detail and sampled, are shown on figure 26. As shown by the analyses, a large part of the shoot contained ore that assayed more than 0.20 percent uranium; other parts of the shoot (not sampled) were low in grade. As the pitchblende ore was intimately mixed with gold-and silver-bearing base-metal ores, most of it was broken with the sulfide ore and subsequently beneficiated by milling. A small part of the ore, particularly on the 228 level, was selectively mined by stripping.

\section{MINERALOGICAL AND CHEMICAL CHARACTER OF WALLROCKS}

The wallrocks of the primary uranium deposits include most of the Precambrian rock units of the region and at one place a bostonite porphyry of Tertiary age. Gneisses and granites of felsic composition are the dominant wallrocks of most deposits; but mafic gneisses form the walls of a few.

The relative abundance of the different rock types constituting the walls of the principal uranium-bearing veins in the region are indicated in table 14 . These data include the wallrocks of the uranium deposits as well as those a few tens of feet away. Microcline-bearing gneiss is the principal wallrock of the uranium deposits in the Central City district (table 14). Bostonite porphyry locally forms the walls of a deposit at the Springdale mine. Granite gneiss and pegmatite, quartz diorite, and garnetiferous lime silicate gneiss and biotite-muscovite granite are the wallrocks for deposits in the Idaho Springs and Lawson-Dumont-Fall River districts.

As shown in table 15, the chemical composition of the common wallrocks in the region "varies considerably. The analyses were made of fresh rocks. The felsic gneisses and granites, which consist mainly of quartz and feldspar and have less than 10 percent mafic minerals, contain abundant silica and low iron and magnesia. The mafic rocks, which contain substantial quantities of biotite, amphibole, garnet, and iron oxides, contain much less silica and more iron and magnesia. The garnetiferous lime silicate gneiss and amphibolite contain large amounts of ferrous iron.

\section{LOCALIZATION OF ORE}

Several interdependent factors were responsible for localizing the uranium deposits. As the pitchblende was precipitated largely as fillings of open"spaces, its occurrence depended primarily on structural features that dilated the walls. Other factors, however, such as proximity of the openings to the source of the oreforming fluids (see p. 53), were important in localizing the deposits. Possibly iron-bearing wallrocks at places had a chemical effect on uranium precipitation.

Although the same types of structural features that controlled deposition of the precious metal-bearing sulfide ores (see Lovering, 1942, p. 81-92) seem to have been responsible for localizing the uranium deposits, the structural controls of the uranium deposits are much less well known. Only a few uranium deposits have been 
Tuble 14.-Wallrocks of uranium deposits

[A, abundant; C, common; R, rare]

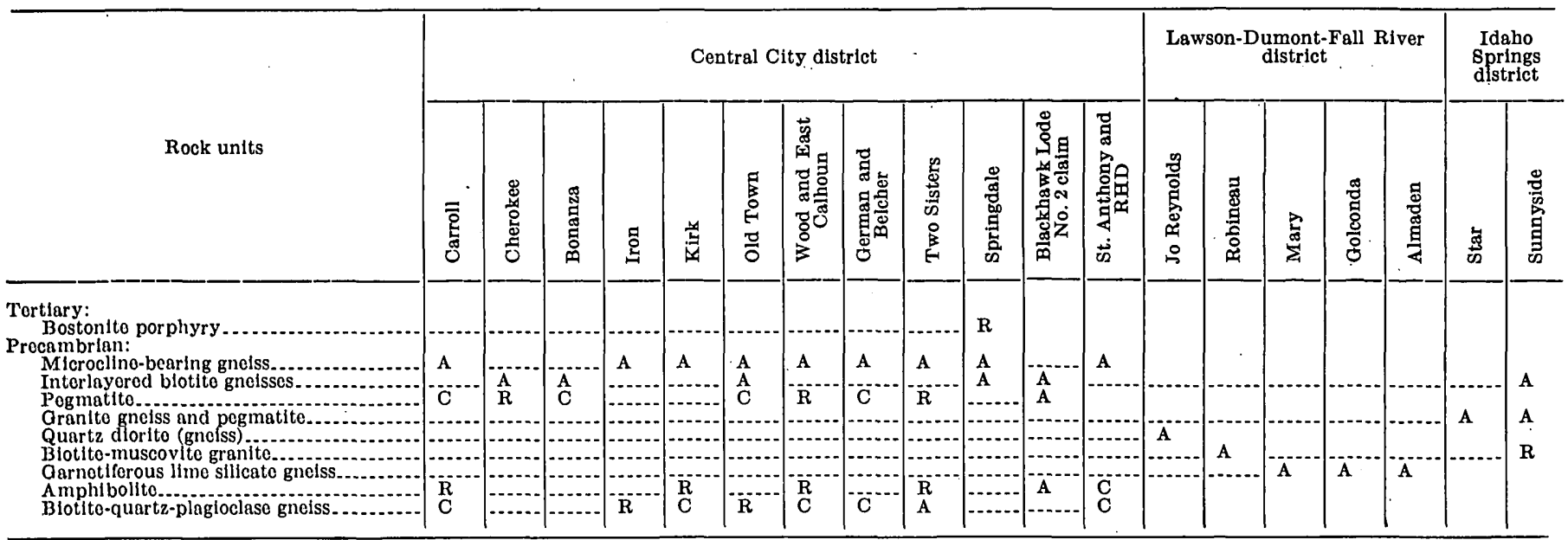

TABLE 15.-Chemical analyses in percent, and modes (volume percent) of wallrocks for uranium-bearing veins

[Analyses by U.S. Geol. Survey]

\begin{tabular}{|c|c|c|c|c|c|c|}
\hline \multicolumn{7}{|c|}{ Analyses } \\
\hline $\begin{array}{l}\text { Chemical } \\
\text { constituent }\end{array}$ & $\begin{array}{l}\text { Micro- } \\
\text { cline- } \\
\text { bearing } \\
\text { gneiss } 1\end{array}$ & $\begin{array}{c}\text { Biotite- } \\
\text { quartz- } \\
\text { plagioclase } \\
\text { gnelss }{ }^{2}\end{array}$ & $\begin{array}{l}\text { Biotite- } \\
\text { musco- } \\
\text { vite } \\
\text { granites }\end{array}$ & $\begin{array}{l}\text { Garnetif- } \\
\text { erous lime } \\
\text { silicate } \\
\text { gneiss } 4\end{array}$ & $\begin{array}{l}\text { Amphib- } \\
\text { olite }\end{array}$ & $\begin{array}{l}\text { Quartz } \\
\text { diorite }\end{array}$ \\
\hline $\begin{array}{l}\mathrm{SlO}_{2} \\
\mathrm{Al}_{2} \mathrm{O}_{2} \\
\mathrm{FaO}_{8} \\
\mathrm{FeO} \\
\mathrm{MgO} \\
\mathrm{CaO} \\
\mathrm{Na} \\
\mathrm{K}{ }_{2} \mathrm{O}\end{array}$ & $\begin{array}{r}76.30 \\
12.20 \\
.90 \\
82.00 \\
.48 \\
1.70 \\
3.70 \\
1.10 \\
.83 \\
.22 \\
.20 \\
.06 \\
.02 \\
. . .\end{array}$ & $\begin{array}{r}76.33 \\
12.30 \\
1.08 \\
1.75 \\
.59 \\
2.41 \\
3.13 \\
1.02 \\
.17 \\
.42 \\
.27 \\
.01 \\
.03\end{array}$ & $\begin{array}{r}71.86 \\
13.19 \\
1.24 \\
1.80 \\
.55 \\
1.29 \\
2.22 \\
5.85 \\
.04 \\
.57 \\
.41 \\
.34 \\
.24 \\
.07 \\
.01 \\
.03 \\
.05\end{array}$ & \begin{tabular}{r}
52.40 \\
8.20 \\
11.70 \\
13.90 \\
2.80 \\
5.40 \\
.10 \\
.49 \\
.74 \\
.32 \\
.25 \\
.70 \\
\hdashline 1.20 \\
3.50 \\
..--
\end{tabular} & $\begin{array}{r}48.19 \\
15.66 \\
3.86 \\
9.08 \\
7.17 \\
8.68 \\
.92 \\
1.07 \\
.67 \\
3.17 \\
.75 \\
.01 \\
.12 \\
.26 \\
.26 \\
\end{array}$ & $\begin{array}{r}52.61 \\
15.63 \\
2.71 \\
6.46 \\
5.67 \\
6.16 \\
2.13 \\
2.85 \\
.12 \\
1.61 \\
.91 \\
2.08 \\
.33 \\
.32 \\
.22 \\
.15 \\
.04\end{array}$ \\
\hline $\begin{array}{l}\text { Subtotal............... } \\
\text { Less oxygen....... }\end{array}$ & 89.71 & $\begin{array}{r}99.51 \\
-2.2 .\end{array}$ & $\begin{array}{r}99.76 \\
.03\end{array}$ & 101.70 & 99.61 & $\begin{array}{r}100.00 \\
.19\end{array}$ \\
\hline Total.. & 99.71 & 99.51 & 99.73 & 101.70 & 99.61 & 99.81 \\
\hline
\end{tabular}

1 East Calhoun mine (6th level), Central City district. Laboratory serial no. 147561. Analysts: P. L. D. Elmore, K. E. White, S. D. Botts, Rapid analysis ratory, Washington, D.C.

' McKay shaft, Central City district. Laboratory serial no. A1. Analyst: . N. Tarrant, Rock analysis laboratory, Denver, Colo.

Jo Reynolds mine, Lawson area. Laboratory serial no. A173. 'Analyst: Jean Theobald, Rock analysis laboratory, Denver, Colo.

- Golconda mine, Fall River area. Laboratory serial no. 140577. Analysts: tory, Washington, D.C.

available for detailed study, and many of these have not been sufficiently developed to determine structural controls. Also, the geologic history of the uranium deposits has been complex. Because uranium generally was deposited early in the sequence of vein filling, the uranium-bearing stringers and pods were partly obliterated at many places by later recurrent movements and by sulfide mineralization (see p. 26), which considerably modified the vein fissures; accordingly little evidence of structural controls can be gained from a study of many deposits.

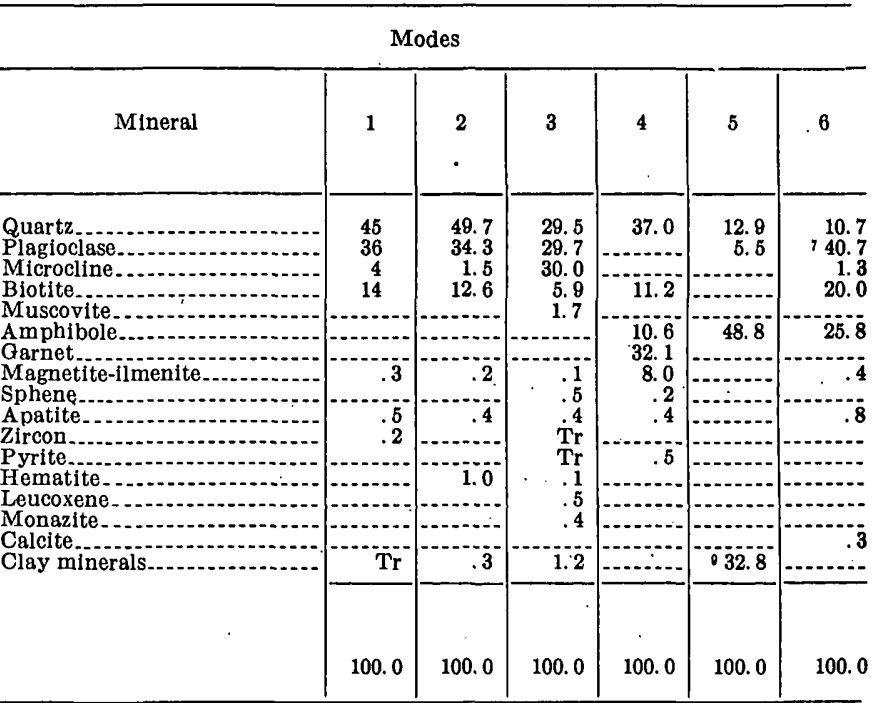

- McKay shaft, Nigger Hill, Central City district. Laboratory serial no. A4 Analyst: L. N. Tarrant, Rock analysis laboratory, Denver, Colo.

6 Nabob mine, Lawson area. Laboratory serial no. A176. Analyst: Jean Theobald, Rock analysis laboratory, Denver, Colo.

\& A calculated correction was made for $\mathrm{FeO}$ present as pyrite based on percentage of $S$. In making this correction it was assumed that all $S$ is present as pyrite.

S. In making this correction

Most of the uranium deposits in the Central City district, as well as sulfide ore deposits, occur between walls of brittle rocks, which are more competent than the adjacent rocks. Several deposits on Quartz Hill in particular can be related to this structural control. The pitchblende ore at the German and Belcher mines, as well as most of the gold-bearing sulfide ore, was mined from stopes on the 130 level (fig. 27); another small stope is on the 256 level. Without exception the stoped ground occurs between walls of microcline-bearing gneiss or pegmatite; the vein is nearly barren in the 


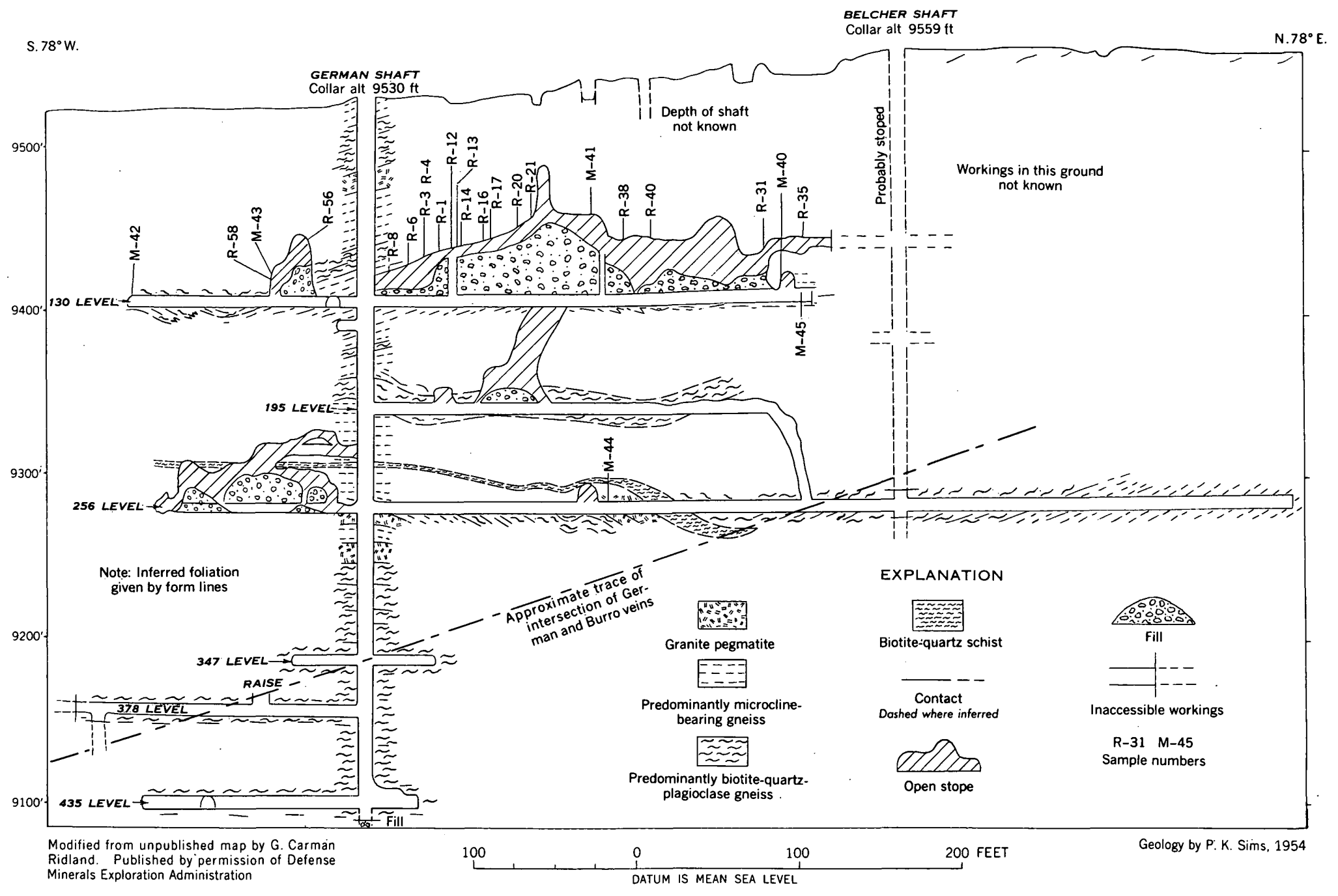

FrodR日 27.-Vertical longitudinal projection of German and Belcher mines, showing relations of stopes to rock type. Assay. data for samples given in tables 19 and 20. 
relatively incompetent biotite-quartz-plagioclase gneiss and biotite schist in the lower mine workings. The localization of ore in relatively brittle host rocks at the German and Belcher mines can be attributed to several interrelated factors that caused deviation, splitting, or brecciation along the fault, and the consequent development of open spaces. The vein fissure, a right-lateral fault, resulted mainly from strike-slip movements, but also had some dip-slip movement. As shown on plates 4 and 5 , the dip of the vein fissure flattens in passing from the more competent microcline-bearing gneiss into the less brittle biotite gneiss, as expected according to theory (Newhouse, 1942). Strike deflections to the right on a smaller scale are also favorable sites for ore deposition (pl. 5), for these deviations are in the direction of the tensional break. Similar factors causing the development of open spaces can be inferred for the localization of ore in the Kirk and Calhoun veins; plate 4 shows that these veins also flatten appreciably in the biotite gneiss.

The uranium deposits at the Almaden, Golconda, and Mary mines, in the Fall River area, occur between walls of garnetiferous lime silicate gneiss, a more competent rock that is interlayered with less competent biotite gneisses; the deposits were probably localized in the openings formed in the more competent unit. However, the occurrence of ore in this rock may be due at least in part in chemical controls rather than to physical controls (see p. 54).

In some deposits the structure as well as the lithologic character of the wallrocks were important factors in localizing ore bodies. At the Carroll mine the zone of favorable ground (or zone of uranium ore shoots), as well as the base-metal ore shoot (fig. 23), plunges moderately westward, virtually parallel to the trace of the intersection of the vein with the lithologic layering and foliation of the wallrocks. The wallrocks, which consist of intimately interlayered microcline-bearing gneiss, pegmatite, and biotite-quartz-plagioclase gneiss, strike northeast and dip on the average about $40^{\circ} \mathrm{NW}$. The Carroll vein strikes about N. $70^{\circ} \mathrm{W}$, nearly normal to the strike of the country rock, and dips moderately northeast. Because the fault has a left-lateral displacement, it is deflected more toward the west each place it passes from an incompetent layer into a competent layer, resulting in crackling, brecciation, and splitting in the microcline-bearing gneiss and the migmatite. .As the maximum brecciation and development of open space is in the more competent rocks, maximum breakage is parallel to the layering in the rocks; accordingly the zone of ore shoots plunges parallel to the intersection of the Carroll vein with the layering (fig.. 23).
Many small lenses and pods of pitchblende-bearing ore occur at vein intersections or in openings related to irregularities along the fissures. At least two deposits in the region seem to have been localized primarily at the intersection of two veins. The pitchblende deposit at the Bonanza mine on Justice Hill occurs at the intersection of the Shamrock and Bonanza veins (fig. 45). The ore is confined to the footwall vein, the Shamrock, and extends only a few feet from the junction. According to Van McKay (oral communication, 1955), the ore plunges southwest about parallel to the junction. Possibly the small uranium bodies at the Two Sisters mine (fig. 41) also are related to a vein intersection, for they are near but west of the intersection of the Two Sisters and the Claire Marie vein fissures. The ore occurrences on the 105 and 179 levels seem to be within a steeply plunging shoot that rakes to the west, virtually parallel to the plunge of the intersection. In many mines small stringers or lenses of pitchblende-bearing ore are in subsidiary fractures near or at their junction with the main faults, for example in the Iron, Mary, Almaden, Golconda, and Sunnyside mines. Small veinlets of pitchblende on the new sixth level of the Old Town mine (fig. 33) seem to occupy gash fractures formed by tensional stresses between two subparallel branches of the Old Town vein. Judging from occurrences at the Carroll mine, small pods of pitchblende-bearing ore commonly occur at the junction of two or more minor discontinuous fractures within a vein or lode.

Many of the uranium deposits are clustered adjacent to known bodies of quartz bostonite porphyry (pl. 1), a fact pointed out earlier by Alsdorf (1916) and Phair (1952) ; the present writers infer that at least some of the uranium in these deposits was derived from local bodies of magma that consolidated to form quartz bos. tonite porphyry.

A possible chemical effect on uranium precipitation, at least locally, can be inferred from the restriction of certain deposits to vein segments between wallrocks rich in iron. In the Fall River area, the known pitchiblende deposits are confined between walls of iron-rich garnetiferous lime silicate gneiss (Hawley and Moore, 1955). In other parts of the region, as at Central City, many of the deposits are near amphibolite wallrocks, but in contrast to Fall River this rock occurs only as small, widely separated bodies. Tooker has concluded from a study of the altered wallrocks that the alteration of ironrich mafic rocks and the consequent release of ferrous iron to the vein-forming solutions may have been an important factor in the precipitation of the uranium (see p. 54). Possibly the reaction of the ore-forming fluids with iron-rich wallrocks contributed to the 
precipitation of uranium even along those veins where iron-rich wallrocks were sparse. Mafic rocks of similar composition form the walls of several deposits in other parts of the Front Range, as in the Ralston Buttes district (Adams and Stugard, 1956; Sims, 1956b, p. 7879 ; Sheridan and others, 1958), and the Copper King mine in Larimer County (Sims, Phair, and Moench, 1958).

\section{RELATION OF PRIMARY ORES TO DEPTH}

Although the uranium deposits generally have not been explored to the same extent as the sulfide deposits that contain the more valuable gold- and silver-bearing ores, some generalizations can be made concerning the vertical continuity of these deposits. The available data indicate that the uranium ore shoots (or zones of ore shoots) in this region do not extend over long vertical ranges, and in this respect they differ greatly from the sulfide ore shoots. The maximum known vertical extent of a group of uranium ore shoots in a vein is about 500 feet and the common vertical range is much smaller, whereas many of the large sulfide ore bodies have been mined for vertical distances of more than 1,000 feet.

The depth below the surface to which known deposits extend, the altitude of the deepest deposits, and the vertical range of series of ore bodies in different mines of the region are given in table 16 .

TABLE 16.-Relation of primary uranium deposits to depth

\begin{tabular}{|c|c|c|c|c|}
\hline \multirow{2}{*}{ District and Mine } & \multicolumn{2}{|c|}{$\begin{array}{l}\text { Deepest uranium } \\
\text { deposits }\end{array}$} & \multirow{2}{*}{$\begin{array}{l}\text { Vertical range } \\
\text { of known } \\
\text { deposits (feet) }\end{array}$} & \multirow{2}{*}{$\begin{array}{l}\text { Depth of } \\
\text { mine } \\
\text { (feet) }\end{array}$} \\
\hline & $\begin{array}{l}\text { Depth } \\
\text { below } \\
\text { surface } \\
\text { (feet) }\end{array}$ & Altitude 1 & & \\
\hline $\begin{array}{l}\text { Central City district: } \\
\text { Blackhawk Lode No. } 2 \text { clalm.. }\end{array}$ & \multirow{8}{*}{$\begin{array}{l}100 \\
100 \\
270 \\
215 \\
255 \\
300 \\
380 \\
449 \\
480 \\
585\end{array}$} & \multirow{8}{*}{$\begin{array}{l}8,600 \\
8,608 \\
8,715 \\
8,395 \\
9,270 \\
8,250 \\
9,080 \\
8,644 \\
8,931 \\
8,745\end{array}$} & \multirow{8}{*}{\begin{tabular}{|l|}
$100 \ldots \ldots$ \\
45 \\
$200 \ldots$ \\
157 \\
200 \\
Smail \\
350 \\
96
\end{tabular}} & \multirow{8}{*}{$\begin{array}{r}>106 \\
270 \\
250 \\
435 \\
>700 \\
380 \\
1,430 \\
685 \\
585\end{array}$} \\
\hline 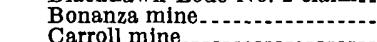 & & & & \\
\hline Cherokee mine-................ & & & & \\
\hline German and Belcher mines... & & & & \\
\hline $\begin{array}{l}\text { Iron min } \\
\text { Kirk mit }\end{array}$ & & & & \\
\hline $\begin{array}{l}\text { Kirk mine... } \\
\text { Old Town min }\end{array}$ & & & & \\
\hline $\begin{array}{l}\text { Springdale mine-. } \\
\text { Wood-Egst Calhoun mine }\end{array}$ & & & & \\
\hline $\begin{array}{l}\text { Wood-East Calloun mine- } \\
\text { Lawson-Dumont-Fall River dis- } \\
\text { trt: }\end{array}$ & & & & \\
\hline $\begin{array}{l}\text { trict: } \\
\text { Almaden mine. } \\
\text { Bellevue-Rochester tunnel-.... }\end{array}$ & 2500 & 8,250 & 300 & (3) \\
\hline $\begin{array}{l}\text { Bellevue-Rochester tunnel... } \\
\text { Golconda tunnel. }\end{array}$ & $\begin{array}{l}2750 \\
2700\end{array}$ & $\begin{array}{l}8,260 \\
8,185\end{array}$ & Small(?) - & $\begin{array}{l}\text { (3) } \\
(3)\end{array}$ \\
\hline $\begin{array}{l}\text { Jo Reynolds mine (Elida tun- } \\
\text { nel). }\end{array}$ & ${ }^{2} 1,000$ & 28,450 & Small(?) & (3) \\
\hline $\begin{array}{l}\text { Mary tunnel } \\
\text { aho Springs district: }\end{array}$ & 2500 & 8,200 & Small_....... & (3) \\
\hline $\begin{array}{l}\text { aho Springs district: } \\
\text { Sunnyside tunnel. }\end{array}$ & 150 & 8,630 & .....do...... & (3) \\
\hline
\end{tabular}

1 Datum is mean sea level.

2 A pproximate figure.

3 Workings are essentially on one level.

Within the central part of the mineral belt primary uranium deposits of known or potential economic importance occur over a vertical range of more than 1,000 feet, between altitudes of 9,525 feet (German and Belcher mines) and 8,185 feet (Fall River area). If the Robineau prospect south of Lawson contains primary uranium minerals, the vertical range is more than 2,000 feet. Within any single district the vertical range of known deposits is still less, and it is substantial only at Central City where known deposits occur between altitudes of 9,525 feet (Quartz Hill area) and 8,395 feet (Cherokee mine). There is no indication that these altitudes represent the upper and lower limits of effective uranium mineralization, but the vertical limits of mineralization are probably small for the deposits within local areas or clusters of deposits.

The deposits within a single vein rarely have a vertical range in excess of 500 feet (table 16), and future exploration probably will not appreciably increase this order of magnitude. The uranium deposits of only a few veins have been developed through vertical ranges of several hundred feet, and of these fewer still have been sufficiently developed to indicate with certainty the limits of uranium ore bodies. The Wood vein in the Central City district, which has yielded a substantial proportion of the uranium ore from the region, has been developed extensively from the surface to the 583 level of the East Calhoun mine; although uranium deposits extend to the level of the lowest workings, the zone of favorable ground containing the ore shoots seems to taper sharply downward (fig. 36). The individual shoots or pods also seem to be much smaller on the lowest level. Uranium deposits in the German vein are wholly confined to the upper levels, and they have a small vertical range. Other deposits, such as the Carroll, extend to the lowest levels of the mines, apparently with no marked reduction in size or abundance of the ore bodies, but this occurrence probably is not more continuous than those developed through greater vertical ranges. The known uranium deposits in the Lawson-Dumont-Fall River district and the Idaho Springs district generally have not been sufficiently explored or developed to determine their full vertical extent, for most of these occurrences have been developed by means of adits, and little work has been done above and below the adit levels.

The marked contrast between the vertical dimensions of uranium ore shoots and precious metal-bearing sulfide ore shoots probably is largely the result of differences in the physicochemical environment of deposition, but it may also be explained in part by differences in the quantities of metal available for deposition and, as stated previously, from differences in structura] environment.

\section{RELATION OF URANIUM DEPOSITS TO SULFIDE MINERAL ZONING}

The uranium occurrences in the veins do not have a distinct position in the hypogene sulfide mineral zon- 
ing pattern (compare fig. 8 and pl. 3). This concept is contrary to earlier views of Leonard (1952), and Armstrong (1952), who concluded that the uranium deposits at Central City occurred in the intermediate zone, for at the time of their studies the known deposits (Quartz Hill) were restricted to this part of the zoning pattern. As described by Sims (1956a, fig. 2), the uranium deposits at Central City occur in each of the zones defined by the precious metal-bearing sulfide ores. The larger deposits and most small occurrences are in the intermediate and peripheral zones.

Wells and Harrison (1954, fig. 2, p. 8) similarly noted in north-central Clear Creek County that uranium occurs in veins of diverse mineralogy, but is sparse in pyrite veins that lack appreciable amounts of copper minerals or other base-metal sulfides.

\section{SUPERGENE ALTERATION}

Some pitchblende-bearing veins grade upward into a relatively simple assemblage of hexavalent hydrous uranium phosphate and silicate minerals which clearly formed by supergene alteration. The presence or absence of the secondary minerals and the nature of the assemblage depend on several factors, the most important being the primary mineralogy of the veins and the lithology of the wallrocks. Concentrations of secondary uranium minerals are confined to galenasphalerite veins; the oxidized part of pyrite veins are devoid of secondary uranium minerals because of leaching by acid sulfate ground water. In galena-sphalerite veins the secondary minerals occur in and adjacent to the originating vein, indicating that alteration and solution of the primary pitchblende and redeposition of secondary minerals occurred virtually in place. Sooty pitchblende commonly occurs at the interface between oxidized and unoxidized parts of the veins.

\section{RELATION OF ALTERATION PRODUCTS TO WATER TABLE AND PRIMARY ORE}

The distribution of secondary uranium minerals is related to the ground-water table. Generally the interface between the zone of hard pitchblende and the zone of secondary minerals is moderately regular and essentially coincides with the water table, but local variations indicate that the zone of secondary minerals is related in part to the permeability of the vein fissures. At most localities secondary uranium minerals do not extend below a depth of about 150 feet below the ground surface, and at places they do not extend below a depth of 100 feet. The lower limit of the zone of secondary uranium minerals closely approximates the bottom of the zone of abundant hydrous iron oxides.

Throughout the region, weathering of pitchblendebearing galena-sphalerite veins produces a relatively

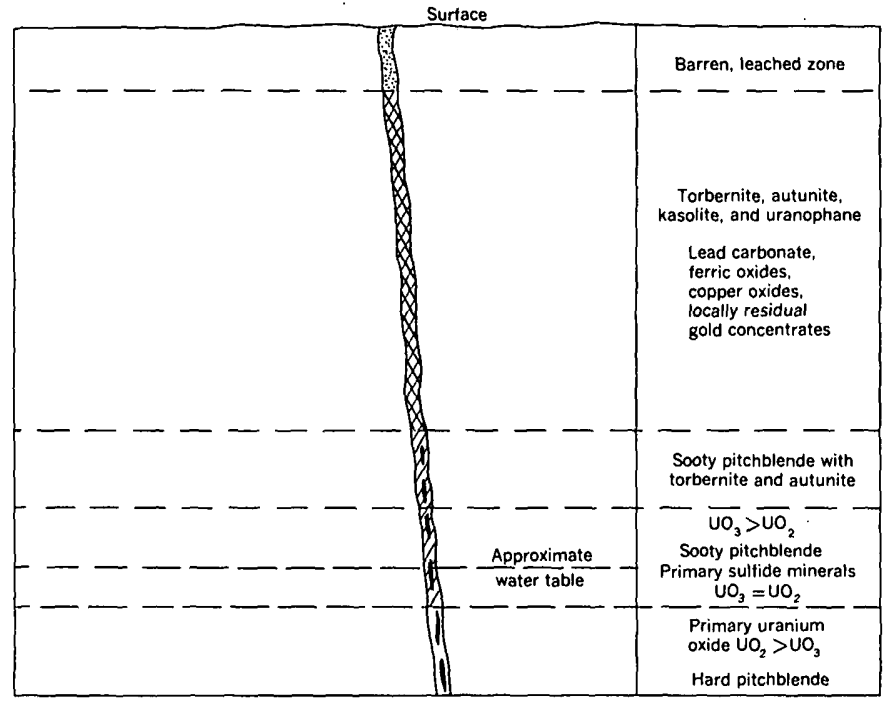

FtguRp 28-Diagram showing relations of secondary and primary uranlum minerals in weathered galena-sphalerite veins, Central City and adjolning mining districts.

simple assemblage of secondary minerals which occur in rather well-defined zones. A section of a hypothetical vein showing the distribution of secondary minerals and their relation to the primary ore is given in figure 28. The diagram is a composite of available data from several deposits in the region. Only one uranium-bearing vein in the region, the Carroll on Nigger Hill, was sufficiently developed during this survey to expose both the oxidized and unoxidized parts of the vein.

As shown in the diagram (fig. 28), weathering of a vein containing pitchblende, with some galena, sphalerite, copper sulfides and sulfosalits, and sparse pyrite, would yield a zone of variable vertical height of hexavalent uranium minerals. This zone can be expected to grade downward through a zone containing soft, porous or sooty pitchblende into hard, unaltered pitchblende. The zone of secondary minerals is capped by a barren leached zone nearly devoid of radioelements. On Silver Hill, in the Central City district, this leached zone is less than 10 feet thick, and on Nigger Hill it is about 25 feet thick. The common secondary uranium minerals concentrated in and adjacent to the veins are torbernite, metatorbernite, autunite, and kasolite; uranophane is rarely present. Although kasolite extends vertically downward to within a few feet of the unaltered pitchblende in at least one vein, the Carroll, it has not been observed in association with sooty pitchblende. The more soluble uranium sulfate, sulfocarbonate, and carbonate minerals can be expected to occur sparsely at places above the uranium phosphate and silicate minerals; generally, however, these minerals are found only as encrustations or as an efflorescence 
on mine walls and clearly formed after development of the mines.

Pitchblende-bearing pyrite veins do not contain concentrations of secondary uranium minerals; instead the veins are leached of uranium and are virtually barren to the approximate depth of the water table where the primary ore occurs.

\section{OCCURRENCE OF SECONDARY URANIUM MINERALS}

The secondary uranium minerals are concentrated in the oxidized original veins, along fractures in the wallrock, and as disseminations in certain wallrocks of favorable lithology. Concentrations of uranium minerals in the wallrocks are rarely found more than 5 feet from an originating vein.

Kasolite, which is abundant in the lead-rich veins on Nigger Hill and Silver Hill, is nearly confined to the oxidized vein fissures. It occurs in association with abundant hydrous iron oxides in the main veins and in tiny limonite-stained fractures adjacent to these veins; the mineral has not been observed more than 2 feet from a main vein. The kasolite commonly occurs as rosettes in vuggy limonite boxwork and as thin films along iron-stained fractures. In the Two Sisters vein on Nigger Hill (fig. 43), kasolite occurs over a known vertical range of at least 140 feet, from depths of about 40 to 180 feet. At the lower depth (179 level), galena with a coating of cerussite is associated with the kasolite; at higher levels all the primary base-metal sulfides are changed to secondary oxides, carbonates, and sulfates.

Metatorbernite and torbernite occur as fracture coatings and as disseminations through certain types of altered wallrocks adjacent to the vein fissures (Sims and Tooker, 1955, p. 1680). The disseminated occurrences are of particular geologic and economic interest and locally constitute ore. At several localities on Nigger Hill (Sims, Osterwald, and Tooker, 1955) and Silver Hill in the Central City district, at the Jennie Lind No. 1 tunnel and Shafter mine in the Idaho Springs district, and at the Martha $\mathbf{E}$ mine in the Chicago Creek district, metatorbernite and probably also torbernite are locally disseminated through altered wallrock adjacent to the originating veins. Without exception the minerals are concentrated only in amphibolite or biotitequartz-plagioclase gneiss, rocks which alter in the supergene zone largely to montmorillonite. At several mines on Nigger Hill and Silver Hill, metatorbernite is disseminated through small, completely argillized podlike bodies of amphibolite adjacent to uraniumbearing veins; commonly the occurrences are within 2 or 3 feet of a vein fissure. The metatorbernite is concentrated in the margins of the altered amphibolite pods and also is abundantly disseminated through the green montmorillonitic clay. Commonly fractures in the altered amphibolite are coated with a thin film of metatorbernite.

Occurrences of metatorbernite in altered biotitequartz-plagioclase gneiss are fewer, but at least one is of potential economic importance. At the Two Sisters mine on Nigger Hill, dump samples of altered biotitequartz-plagioclase gneiss that contains abundant biotite and sparse quartz contain abundant disseminated metatorbernite. The material has not been found in place in the mine, but by analogy with known geology the occurrence can be interpreted with reasonable certainty. The metatorbernite occurs in both moderately and intensely altered gneiss which surrounds the vein, but does not occur in the fresh rock. In the moderately altered gneiss-where most of the plagioclase has been transformed into a montmorillonite-kaolinite mixture but biotite is unchanged-the metatorbernite occurs as tiny granules and aggregates of granules. These granules are closely associated with biotite, often penetrating the mica crystals where bent or flexed. Grain boundaries are commonly smooth and regular. In the more intensely altered rock-where biotite is bleached and partly altered to clay minerals - the metatorbernite is flake-shaped and appears to be intimately related to mica and clay minerals. The texture is interpreted to indicate that as the biotite was altered (megascopically bleached) to illite-montmorillonite, the metatorbernite replaced the altered mica along cleavage planes and crystal edges. A marked concentration of metatorbernite occurs in the transition zone between moderately and intensely altered gneiss. Similar occurrences of disseminated metatorbernite occur in the Jennie Lind No. 1 tunnel, Shafter mine, and Martha E mine, but the mineral appears to be less abundant in these altered rocks.

Autunite and rarely meta-autunite are closely associated with torbernite at some localities, but generally are much less abundant. At the Martha $\mathrm{E}$ mine autunite occurs with torbernite as coatings on fractures in the footwall of the main vein fissures (see pl. 9). Both minerals are closely associated with sooty pitchblende.

Sooty pitchblende occurs at the interface between oxidized and unoxidized uranium-bearing veins and may or may not be associated with torbernite and autunite. At most places the sooty pitchblends is clearly a transitional alteration phase between the hard, unaltered pitchblende and highly colored hexavalent uranium minerals. However, at the Golconda mine in the Fall River area where sooty pitchblende extends to depths below the oxidized zone, Hawley and Moore have 
interpreted the material to probably have been deposited from hypogene solutions. The change from hard pitchblende with a well-developed colloform texture to soft, sooty, loosely aggregated pitchblende can be observed in the Carroll vein on Nigger Hill (fig. 23). In general sooty pitchblende is abundant, at least locally, at and above the 177 level, and is rare at greater depths, but the transition from the hard to the soft material is gradual and locally is clearly related to the relative permeability of the vein structure. Although most of the pitchblende on the 228 level was hard and colloform, some of it that occurred in the more permeable fissures was locally changed to the soft material. The pitchblende in the large stope above the 177 level, and in the raise above the level, is generally soft and crumbly; some of it is highly leached (samples C-1-8A and C-112, table 26).

\section{GRADE OF SECONDARY DEPOSITS}

The grade of the secondary uranium deposits commonly is lower than that of the primary deposits, and only two small shipments (table 1) of this type of ore have been made. Further exploration, however, may prove that some secondary uranium deposits can be mined profitably, particularly if the ore material can be beneficiated by milling.

Mining of secondary uranium deposits on Nigger Hill and Silver Hill in the Central City district, and at the Martha $\mathrm{E}$ mine in the Chicago Creek area indicates that secondary deposits commonly consist of material that contains on the average slightly more than 0.10 percent uranium. Locally, material of higher grade which can bo selectively mined occurs in the deposits. The ore is of two types, one consisting of altered original vein material containing abundant hydrous iron oxides and the other consisting of altered wallrock that is impregnated with secondary uranium minerals.

The secondary uranium deposits that have been mined at the Blackhawk Lode No. 2 claim on Silver Hill consist of both altered vein material and uranium-bearing wallrock. A deposit developed by the shaft (fig. 51), consisted entirely of kasolite-bearing altered vein material and yielded about 8 tons of ore that contained an average of about 0.30 percent uranium. Several small bodies of altered amphibolite that were mined from the adit (fig. 52) yielded about 25 tons of low-grade material. About 3 tons of sorted material contained an average of 0.20 percent equivalent uranium and 0.26 percent uranium; the remainder contained an estimated 0.15 percent uranium.

At the Martha $\mathrm{E}$ mine in the Chicago Creek area, torbernite and autunite occur along joints and foliation planes in the footwall of a shear zone containing sooty pitchblende and hydrous iron oxide. The average grade of 21 samples cut in the mine is 0.031 percent uranium. A small shipment of hand-sorted ore (table 1) assayed 0.14 percent uranium.

Secondary uranium deposits mined on Nigger Hill are similar in both type and grade to those on Silver Hill. Uranium occurs both in altered vein material containing kasolite and abundant hydrous iron oxide and in mineral dispersed through highly altered wallrocks of two types-amphibolite and biotite-quartzplagioclase gneiss. Except locally, most of the material contains less than 0.20 percent uranium. A deposit consisting largely of metatorbernite-bearing altered amphibolite exposed on the 40 level of the McKay shaft, R.H.D. claim (fig. 37; Sims, Osterwald, and Tooker, 1955, fig. 2 and table 2) contains a few tons of material that is estimated to have an average uranium content of 0.12 to 0.15 percent; little if any of the metatorbernite-bearing rock contains as much as 0.20 percent uranium. A small lens of uraniumbearing material in the Easton vein, St. Anthony mine (fig. 40), contains a maximum of 0.11 percent equivalent uranium and 0.14 percent uranium. Kasolite-bearing, limonitic vein material from the Two Sisters mine (fig. 41) contains on the average less than 0.05 percent uranium, but locally contains higher grade material. Metatorbernite-bearing altered biotite-quartz-plagioclase gneiss, found on the dump but not located underground, contains much more uranium, and selected dump samples have as much as 6.11 percent uranium. Five hundred and ten pounds sorted from the dump assayed 1.53 percent uranium.

\section{ChEMICAL CONSIDERATIONS}

Pitchblende is stable under reducing conditions but is readily soluble in an acid oxidizing environment. The iron sulfide in the veins in the district dissociates upon oxidation by atmospheric oxygen, and generates acid sulfate water that attacks the pitchblende. The first stage of alteration of pitchblende is to amorphous $\mathrm{UO}_{3}$, perhaps by essentially solid-state reaction without the intervention of a solution step. The $\mathrm{UO}_{3}$ forms with a corresponding reduction in $\mathrm{UO}_{2} ; \mathrm{UO}_{3}$, being more soluble than $\mathrm{UO}_{2}$ in dilute acid solutions, is preferentially leached with respect to $\mathrm{UO}_{2}$ and also radium and lead (Phair and Levine, 1953, p. 362-363). $\mathrm{UO}_{3}$ forms uranyl salts in acid solutions according to the relation:

$$
\mathrm{UO}_{3}+\mathrm{H}_{2} \mathrm{SO}_{4}^{-2} \rightleftharpoons \mathrm{UO}_{2}^{+2}+\mathrm{SO}_{4}^{-2}+\mathrm{H}_{2} \mathrm{O}
$$

and these uranyl salts are very soluble in aqueous solutions. The uranyl ion, $\left(\mathrm{UO}_{2}\right)^{+2}$, in combination with anions such as phosphorus, forms relatively insoluble 
complexes; in combination with other anions, such as carbonate and sulfate, it forms very soluble complexes. For the general relations between tetravalent uranium compounds and hexavalent uranium comounds in aqueous solutions, the reader is referred to McKelvey and others (1955, p. 470, fig. 2).

During the initial stages of pitchblende alteration in the zone of oxidation, $\mathrm{UO}_{2}$ changes at a finite rate to amorphous $\mathrm{UO}_{3}$; the $\mathrm{UO}_{3}$, once formed, is much more readily leached than the $\mathrm{UO}_{2}$ in $\mathrm{H}_{2} \mathrm{SO}_{4}$ water (Phair and Levine, 1953, p. 363, table 2). As oxidation progresses toward a $\mathrm{UO}_{3}$ rich pitchblende, the mineral changes to a more porous form, the hardness decreases, and the specific gravity decreases. The pitchblende retains its colloform texture and remains coherent until, at an advanced stage of alteration, it becomes sooty and loosely aggregated. In this form it can be moved, presumably by mechanical transportation, in the ground water, for sooty pitchblende commonly is observed coating sulfide and gangue minerals in vugs or as coatings on fractures that formed after sulfide mineralization. The magnitude of migration, however, is small in the galena-sphalerite veins, and probably does not exceed a few feet. In general, analyses show that sooty pitchblende material is essentially in equilibrium, indicating that although the uranium in the mineral is considerably oxidized the daughter products commonly remain with the uranium, and the uranium with the daughter products. If there were substantial active leaching, relative movement of uranium and daughter products should have disrupted this equilibrium. Rarely, for example near the interface of the zone of sooty pitchblende and the zone of hexavalent uranium compounds at the Carroll mine (fig. 23), the sooty pitchblendebearing material shows disequilibrium (see analyses $\mathrm{C}-1-8 \mathrm{~A}$ and $\mathrm{C}-1-12$, table 26); uranium has been leached and radium and other daughter products have remained in place to account for the disequilibrium.

At a further stage of alteration, the pitchblende is completely dissociated and taken into solution, probably according to the relation shown on page 51, and hexavalent uranium minerals are formed by the combination of the uranyl ion $\left(\mathrm{UO}_{2}\right)^{+2}$ with available anions in the ground water. The uranium phosphates torbernite and autunite and the uranium silicates kasolite and uranophane are formed most commonly. Once formed they tend to be stable except locally where they are exposed at the outcrop. Uranyl hydroxide hydrates, which are common in many uranium-producing areas, are absent so far as known. Torbernite and kasolite commonly form in sulfide-rich veins where base-metal ions are abundant, as on Nigger Hill and Silver Hill (Central City district), whereas autunite and uranophane preferably form in more sulfide-poor environments. Judging from the field relations and tenor of the secondary uranium deposits, redeposition of the secondary minerals occurred at the approximate site of solution of the primary oxide mineral. Migration of the uranium at least short distances away from the vein is indicated, however, by the presence of disseminated hexavalent uranium minerals (such as metatorbernite) in altered wallrocks and coatings on fractures (metatorbernite and autunite) in these rocks. This interpretation is supported also by the disequilib. rium between equivalent uranium and uranium in these ores, for in general, analyses of material containing abundant hexavalent uranium minerals show uranium in excess of equivalent uranium, indicating at least a partial separation of uranium from its daughter products.

Presumably precipitation of the uranyl compounds resulted from neutralization of the sulfate ground water by reaction with ore minerals that were effective in decreasing the acidity of acid sulfate solutions (see Emmons, 1917, p. 124-137) and by reaction with wallrocks. Evidently the latter was most important, for with the exception of kasolite, concentrations of hexavalent uranium minerals are nearly confined to those wallrocks that were largely altered to montmorillonite. The more soluble uranium compounds, the sulfates and carbonates, were not stable in the oxidation zone and were dispersed in the ground and surface water.

The absence of hexavalent uranium minerals in pyrite-rich veins is attributed to the high content of free $\mathrm{H}_{2} \mathrm{SO}_{4}$ in the supergene solutions (Phair and Levine, 1953, p. 367). Water from a mine tunnel near Idaho Springs (Clarke, 1924, p. 644) contained 0.13 grams per liter of $\mathrm{H}^{+^{1}}$ and 18,260 ppm (parts per million) of $\mathrm{SO}_{4}^{-2}$; this is a 0.13 normal solution of $\mathrm{H}_{2} \mathrm{SO}_{4}$. Mine water from the Quartz Hill-upper Russell Gulch area in the Central City district also is extremely acid sulfate water and has a low $\mathrm{pH}$. The water is so corrosive that the clothing of the miners is sometimes eaten to shreds in a few days, and iron rails, pipes, and nails must be replaced frequently (Bastin and Hill, 1917, p. 255). In this environment, oxidation by the highly acid sulfate water rapidly leaches the uranium from the pitchblende, and in the absence of abundant quantities of minerals that can effectively neutralize the solutions, the uranium remains in solution and is carried out of the system into surface water.

\section{ORIGIN OF URANIUMI DEPOSITS}

The uranium deposits in the region can logically be assumed to have been derived from the same magmatic source as the gold- and silver-bearing sulfide vein de- 
posits. Presumably uranium was a sparse component of the ore-forming fluid that yielded the base-metal ores, but rarely was sufficiently concentrated to yield valuable deposits. At places, however, uranium-bearing fluids of a local source, probably derived directly from relatively shallow cooling quartz bostonite porphyry dikes, mingled with the dominant fluids from the deepseated source to yield deposits of economic importance. These deposits, near dikes of quartz bostonite porphyry, are most abundant in the Central City district.

\section{SOURCE OF URANIUM}

The evidence for the derivation of uranium from the magmas that consolidated to form the early Tertiary porphyritic igneous rocks in the region is much less equivocal than in most mining districts. In addition to close spatial and temporal relations of the ore and the igneous rocks, which commonly are the principal reasons for interpreting a consanguinous origin, several other lines of evidence support this hypothesis: abnormal concentrations of uranium of the porphyritic igneous sequence, demonstrable enrichment of uranium in successively younger members of the sequence, and a close association of uranium and zirconium in the rocks and ore.

As shown previously in this report (p. 13), the porphyritic igneous rocks of this region contain abnormal quantities of both uranium and thorium. Further, many analyses of the rocks for the radioelements clearly indicate that uranium and thorium were enriched in successively younger magmatic phases of the igneous sequence and that enrichment culminated in the magma that consolidated to form quartz bostonite porphyry (Phair, 1952; Wells, 1960). The quartz bostonite porphyry contains an average equivalent uranium content of 0.011 percent and an average uranium content of 0.004 percent.

Information on similarities in the chemistry of the younger members of the igneous rock sequence and the pitchblende further support a consanguinous origin for the rocks and the uranium. Phair (1952, table 3) has shown that bostonite porphyry and quartz bostonite porphyry, the youngest intrusive rocks emplaced before mineralization, contain 4 to 9 times as much zirconium as the average granitic rock, assumed by Phair to contain 0.02 percent $\mathrm{ZrO}_{2}$. He also showed (Phair, 1952, fig. 3) that in the quartz bostonite porphyry radioactivity increases directly with an increase in zirconium, which he interprets to indicate that the radioelements and zirconium are closely associated, probably in a ladioactive zircon. It has long been known (Hillebrand, 1891, p. 65-66) that the pitchblende from Central City contains abnormally large amounts of zirconium.
Hillebrand's chemical analysis indicated 7.59 percent $\mathrm{ZrO}_{2}$ in the analyzed pitchblende; spectrographic data obtained during the current studies indicate similar amounts of zirconium in pitchblende, both from Central City and from Lawson (table 13).

The data on the enrichment of uranium in the igneous sequence during differentiation and the chemical association of uranium and zirconium in the uranium ores and the rocks are interpreted to indicate that the Tertiary igneous rocks were the source of the uranium. The fracturing that took place after the emplacement of the radioactive quartz bostonite porphyry provided channels for the escaping hydrothermal fluids that were derived from the differentiating source magma.

Except locally, uranium probably was a minor component of the ore fluid that yielded the zoned ore deposits of the region, for although uranium occurrences are widely distributed, most of them are small and not economically important.

The local association of clusters of uranium deposits with dikes of quartz bostonite porphyry is interpreted to indicate that some uranium was derived directly from scattered bodies of quartz bostonite porphyry, which were upward extensions of the much larger magma body of the main chamber. At Central City, and particularly on Quartz Hill and Nigger Hill (compare pls. 1, 3,4 , and fig. 37), clusters of uranium deposits that include some of the most valuable ore bodies in the region are near quartz bostonite porphyry dikes, and most deposits are within 500 feet of a known dike. To explain the abundance and large quantity of uranium in these deposits, the writers, infer in agreement with Phair (1952), that the uranium probably was derived from the local magmas that consolidated to form quartz bostonite porphyry. This increment of uranium to the ore-forming fluid must have been substantial, and perhaps exceeded the total amount derived from the deepseated source.

The ultimate source of the uranium is of course highly speculative, but it can be assumed to have been derived by some process of concentration from the Precambrian basement rocks, provided the radioactive Precambrian rocks now exposed extended to the depth at which magma was generated in early Tertiary time. Both uranium and thorium are widely distributed and locally unusually abundant in certain Precambrian granites and pegmatites in the central part of the Front Range. (See p. 9-13.) Remelting of similar rocks at depth during the early Tertiary magmatic activity, concentration of the radioelements during differentiation of the Tertiary magma sequence, and finally the development of uranium-bearing hydrothermal phases, may account for the uranium deposits. 


\section{CHEMICAL ENVIRONMENT OF DEPOSITION}

The chemistry of the vein environment is speculative, but something of the nature of the ore-forming solution and the cause for uranium precipitation can be inferred from observed field relations, mineralogy of the veins and wallrocks, and experimental laboratory data on the synthesis of uranium.

As stated earlier in this section, the uranium is assumed to have been derived from the magmas that consolidated to form the Tertiary igneous sequence. Until the beginning of hydrothermal conditions, $\mathrm{U}^{+4}$ and $\mathrm{Th}^{+4}$ were intimately associated in the magma, because of the similarity in their ionic radii and charge. In general, both $\mathrm{U}^{+4}$ and $\mathrm{Th}^{+4}$ increased during differentiation in about the same ratio. $\mathrm{Th}^{+4}$ is absent, however, in the pitchblende veins. To explain the separation of $\mathrm{Th}^{+4}$ and $\mathrm{U}^{+4}$, Phair (1952, p. 41-42) proposed that at a late magmatic stage, oxidation of the uranium to the hexavalent state would permit $\left(\mathrm{UO}_{2}\right)^{+2}$ to be carried away in solution, and separated from the $\mathrm{Th}^{+4}$ which could not be oxidized at that stage. As the uranyl ion is readily soluble in acid solutions it could then be transported in hydrothermal fluids.

Judging from the minerals deposited with uranium (p. 39), the composition of the uranium ore-forming fluid must have been relatively simple. Aside from pitchiblende, quartz and pyrite were the principal minerals deposited, except in the deposits in the Fall River district, which contain minor amounts of nickel minerals. Apparently, therefore, the fluid contained ferric iron, silica, and the sulfide ion in addition to the uranyl ion. Possibly the uranium and iron were carried as a colloidal phase, perhaps in a silica gel, for the colloform texture and absence of veining relations to other vein minerals suggest that the pitchblende was deposited as a colloid. There is no compelling evidence, however, that a colloform texture necessarily indicates a colloidal origin, and further studies of this subject are needed.

It is presumed that precipitation of the pitchblende resulted from reduction of the $\mathrm{U}^{+6}$ ion to the $\mathrm{U}^{+4}$ ion, probably as a consequence of cooling of the ore-forming fluid and by the introduction of $\mathrm{Fe}^{+2}$ into the fluid by the breakdown of iron-bearing minerals in mafic wallrocks (p. 47). As the hydrothermal solutions moved upward through the fissures they were cooled by heat lost to the country rock and by mixing of the solution with cooler water of surficial origin. When the temperature had fallen sufficiently to permit reducing conditions to set in, the fluids become saturated with uranium, at which time pitchblende, consisting largely of uranium in the quadrivalent state, started to precipitate along with its associated minerals. Perhaps the fluids that were derived from local, shallow quartz bostonite magma sources were cooled moderately rapidly as they moved outward into the vein fissures and mingled with the more pervasive, ore-forming fluid of deep-seated origin, for a thermal gradient probably existed around the cooling dikes (Phair, 1952, p. 45) and the solutions derived from these local sources were warmer than the dominant, deep-seated ore-forming fluids. This could account for the restriction of many uranium deposits to the vicinity of quartz bostonite porphyry dikes.

The importance of reduction of the $\mathrm{U}^{+6}$ ion by $\mathrm{Fe}^{+2}$ cannot be evaluated fully. The restriction of the uranium deposits in Fall River to those parts of the veins having garnetiferous lime silicate gneiss walls can be interpreted to indicate that reaction with the iron-rich wallrocks and the release of $\mathrm{Fe}^{+2}$ to the ore fluid may have been the principal cause of precipitation in this environment. That this mechanism can cause precipitation of pitchblende has been determined experimentally by Gruner (1952) and others. It is supported by the many occurrences of pitchblende deposits throughout the world in mafic host rocks. Elsewhere throughout this part of the Front Range, some deposits at Central City and many others throughout the adjacent area have, at least locally, walls of amphibolite or quartz diorite (see table 14). These rocks, although generally not abundant, could, upon alteration, contribute $\mathrm{Fe}^{+2}$ to the ore-forming fluid. Tooker has shown (this report, p. 28) that the alteration of amphibolite and related mafic rocks releases $\mathrm{Fe}^{+2}$ to the solutions, even under the most intense alteration conditions. Although the quantities of $\mathrm{Fe}^{+2}$ released in this manner may not be large, they may be sufficient to contribute to the reduction of the uranyl ion in the fluid.

Some inferences can be made regarding the temperature of the uranium ore-forming fluid but there are no known means whereby the temperature can be determined directly. It is postulated from data on the wallrock alteration and temperature estimates by sphalerite geothermometry at Central City (Sims and Barton, 1961) that the pitchblende probably formed above a temperature of about $150^{\circ} \mathrm{C}$ (the presumed temperature due to the geothermal gradient) and below a temperature of $500^{\circ} \mathrm{C}$. Possibly it formed predominantly in the temperature range from $200^{\circ}$ to $300^{\circ} \mathrm{C}$.

\section{AGE}

Age determinations by the $\mathrm{Pb}^{206} / \mathrm{U}^{238}$ method on uraninite from the Wood mine and the Iron mine gave ages ranging from 57 to 70 million years after suitable common lead corrections; age determinations by the $\mathrm{Pb}^{210}$ method on uraninite from the German mine gave a similar age, 58 \pm 3 million years (Faul, 1954, table 9, p. 263). 
The beginning of the Tertiary has been dated by Holmes (1947, p. 145) from two pitchblende samples that gave $\mathrm{Pb}{ }^{200} / \mathrm{U}^{238}$ ages of 57.3 and 59.8 million years, respectively.

\section{FUTURE PRODUCTION}

The uranium-bearing ore bodies in the region are small but generally high in grade, and they have been mined largely in conjunction with precious- and basemetal ores. The discovery of bodies that are larger than those previously mined is doubtful, accordingly future production of uranium from this region will probably be from scattered small bodies distributed along the uranium-bearing veins. These bodies can be recovered most economically as byproducts of the more valuable sulfide ores.

Most of the new discoveries in the future will probably be made near outcrops of quartz bostonite porphyry, for most of the larger productive pitchblende deposits are clustered near exposures of these rocks. Veins that contain known ore bodies are particularly promising for the discovery of new ore shoots, but adjacent veins are also favorable sites for the location of uranium deposits.

\section{MINE DESCRIPTIONS}

The known radioactive vein localities in the region are shown on plate 3 , and analyses of selected samples of radioactive materials from these localities are given in tables 9,10 , and 11 . In this section the veins that contain uranium deposits of economic or geologic interest are described in detail and data are given on grade and tonnage. Information concerning the precious metal-bearing sulfide deposits and their geologic setting can be obtained from the reports on the separate mining districts.

Although the mines are listed alphabetically in the index to this report, they are taken up on the following pages according to district and areas within the districts, for a geographic grouping is useful in comparing adjacent deposits. Because of the large number of important uranium deposits in the Quartz Hill, Nigger H.ill, and Justice Hill areas in the Central City district, detailed geologic maps are presented of these areas.

\section{CENTRAI CITY DISTRICT}

Aside from 8 tons of uranium ore which was shipped from the Jo Reynolds mine and a small shipment of low-grade ore from the Martha $\mathrm{E}$ mine (table 1), the Central City district has supplied all the uranium ore from the region. Most of the production has been high-grade pitchblende ore from the Quartz Hill area, and it was used largely as a source of radium. In recent years, small quantities of uranium ore have been mined from the Nigger Hill, Justice Hill, and Silver Hill areas.

\section{QUARTZ HILLUPPER RUSSELL GULCH AREA}

The Quartz Hill-upper Russell Gulch area contains 33 known radioactive localities within an area of less than 1 square mile (pl. 3). Three mines on Quartz Hill, the Kirk, Wood, and German-Belcher, have produced ore containing 110,667 pounds of $\mathrm{U}_{3} \mathrm{O}_{8}$ (table 1), which represents about 90 percent of the total uranium production from the region. Most of the shipments consisted of high-grade hand-sorted pitchblende ore.

The Quartz Hill-upper Russell Gulch area is one of the more important mining areas within the mineral belt, and it has contributed a substantial proportion of the total metal production from the Central City district. The ore is chiefly valuable for its gold, but in addition to uranium, it contains substantial silver, lead, copper, and zinc.

The area lies astride the Central City anticline, the principal fold in the Central City district (pl. 4). A layer of microcline-bearing gneiss, estimated to be about 3,000 feet thick, is exposed on the crest of the fold, and a sequence of interlayered biotite gneisses is exposed on the flanks. Both of these rock units contain small lenses of amphibolite, cordierite-amphibole gneiss, lime silicate gneiss, and locally other rock types. At Quartz Hill, two prominent layers of biotite-quartz-plagioclase gneiss occur in the microcline-bearing gneiss at relatively shallow depths (pl.4). The uppermost layer, which is remarkably continuous and uniform in thickness, was cut in several mines on Quartz Hill and in upper Russell Gulch, and as shown on plate 4, several mines were bottomed in the layer. The workings on other veins, such as the Bezant in the East Calhoun mine, are bottomed in the lower layer of biotite gneiss (see Lovering and Goddard, 1950, fig. 63).

Several dikes of quartz bostonite porphyry, which constitute the northwestward-trending Wood dike group, cross Quartz Hill and cut the northeastwardtrending Topeka dike of bostonite porphyry near the Wyandotte mine (pl. 4).

Several veins in the area contain local occurrences of uranium, but the principal deposits are in veins that trend east, east-northeast, and northeast.

\section{FLACK VEIN}

The Flack vein, on the north slope of Quartz Hill immediately south of the California-Hidden Treasure vein, was worked from shafts on the following patented claims, from west to east: West Flack (claim 664), East Flack (claim 929), Flack (claim 65), Mercer County 
GEOLOGY OF URANIUM DEPOSITS, FRONT RANGE MINERAL BELT, COLO.

(claim 732), and Mercer County (claim 139). The West Flack and Mercer County (claim 732) mines were accessible in 1953 and 1954 and these mines are described on the following pages; the other mines were inaccessible. The recorded production (metal contained in ore produced) from the Flack vein for 1869 and 1889-92 was 7,229 troy ounces of gold, 4,177 ounces of silver, and 72,000 pounds of copper $^{3}$; and the recorded production for $1903,1908,1910-12,1935-37,1939$, and 1941 was 401 tons of ore containing 103 troy ounces of gold, 460 ounces of silver, 1,708 pounds of copper, 1,692 pounds of lead, and 898 pounds of zinc. ${ }^{4}$

The Flack vein strikes N. $80^{\circ}$ E. to N. $85^{\circ}$ E. and dips steeply south, but there are minor local variations in both dip and strike. It joins with the California vein east of the California shaft and probably was explored from the California workings from crosscuts on the 600 and 1,400 levels; it is a pyrite vein that contains galena, sphalerite, and copper minerals. All the dumps contain abundant pyrite and some galena and sphalerite, but the proportion of the latter decreases eastward along the strike of the vein, and sphalerite is particularly sparse on the dump at the shaft on the Mercer County claim 139.

Pitchblende occurs on the dumps of the shafts on the Flack 664 and Fląck 65 claims. An analysis of the material at the Flack (claim 65) shaft gave 0.43 percent equivalent uranium and 0.024 percent uranium (table 9). In the Flack (claim 664) mine, a boulder containing a 3 -inch layer of pitchblende-bearing ore was found on a muck pile in the stope east of the shaft at a vertical depth of about 170 feet, but pitchblendebearing ore was not found in place. In 1954, Don Malleck (oral communication) found that pitchblende is present in a vein at the shaft at a vertical depth of about 150 feet; presumably this was the source for the boulder.

The Mercer County (claim 732) mine contains substantial radon, and accordingly radiation detection instruments could not be used satisfactorily in the mine; random sampling of the vein, however, failed to disclose uranium of ore grade.

The presence of radioactivity at intervals along the Flack vein for a length of 1,000 feet makes the vein a potential source of small quantities of uranium ore, which might be mined as a byproduct of precious- and base-metal ores.

\section{WEST FLACK MINE}

The West Flack mine, on patented claim 664, consists of a shaft 475 feet deep with levels at vertical

\footnotetext{
${ }^{3}$ Compiled from published annual reports of Director of the Mint.

${ }^{4}$ Compiled from U.S. Bureau of Mines records. Published by permission.
}

depths of 100, 160,320,410, and 475 feet (fig. 29). All the stoping was done above the 320 level, and most of it was done above a depth of 190 feet. A 15-foot winze, 80 feet west of the shaft on the 475 level, connects with a drift that was driven west from the East Flack mine. In 1953 this drift was partly filled with water.

Microcline-bearing gneiss is the predominant wallrock in the upper part of the mine, but biotite-quartzplagioclase gneiss and amphibolite, with lenticular pegmatite bodies, predominate in the lower workings. The rocks strike northeastward and, except locally, dip gently northwestward. A sheared radioactive pegmatite, 3 to 5 times the background count, was intersected in the shaft just above the 410 level. A Tertiary quartz bostonite porphyry dike is present on the 160 level, 60 feet west of the shaft. The dike strikes about N. $35^{\circ}$ W. and dips $55^{\circ}-60^{\circ} \mathrm{NE}$; it is offset along the Flack vein and has an apparent horizontal displacement of 9 feet, the north side having been moved relatively to the east.

Within the mine the vein ranges in strike from N. $85^{\circ}$ W. to N. $80^{\circ} \mathrm{E}$., and dips $70^{\circ} \mathrm{S}$. to $90^{\circ}$. For the most part the vein is less than 1 foot thick, but it ranges from 0 to about 2 feet in thickness. A prominent split occurs at a depth of 200 feet in the shaft (fig. 29), where the dip of the main vein flattens from $90^{\circ}$ to $76^{\circ} \mathrm{S}$. The footwall split appears to pinch out within 50 feet of the vein junction. Other subsidiary branching veins that strike $\mathrm{N} .70^{\circ} \mathrm{E}$. and $\operatorname{dip} 80^{\circ} \mathrm{S}$., are present on the 475 level.

The vein in the West Flack mine consists of white to gray quartz, pyrite, and reddish-brown sphalerite, with lesser quantities of galena, chalcopyrite, marcasite, calcite, and pitchblende in silicified and pyritized wallrock. The quartz commonly forms small veinlets a few inches in maximum width. Small discontinuous stringers of calcite at places cut all these minerals. The galena, sphalerite, and chalcopyrite are mainly in stringers or lenticular pods, which in part cut across the quartz- and pyrite-bearing vein material. The lenses observed by the writer range from 2 to 6 inches in thickness and from a few feet to 50 feet in length. Possibly these lenses, which are probably the principal source of basemetal ore, were larger and more closely spaced in the stoped ground. As pitchblende-bearing ore has not been seen in place, its occurrence in the vein is not known.

An examination of polished sections of the pitchblende from the boulder found in the stope (fig. 29) shows that all the pitchblende has a well-developed colloform structure. Commonly the pitchblende occurs as aggregates of 1-mm-sized spheroidal forms having 


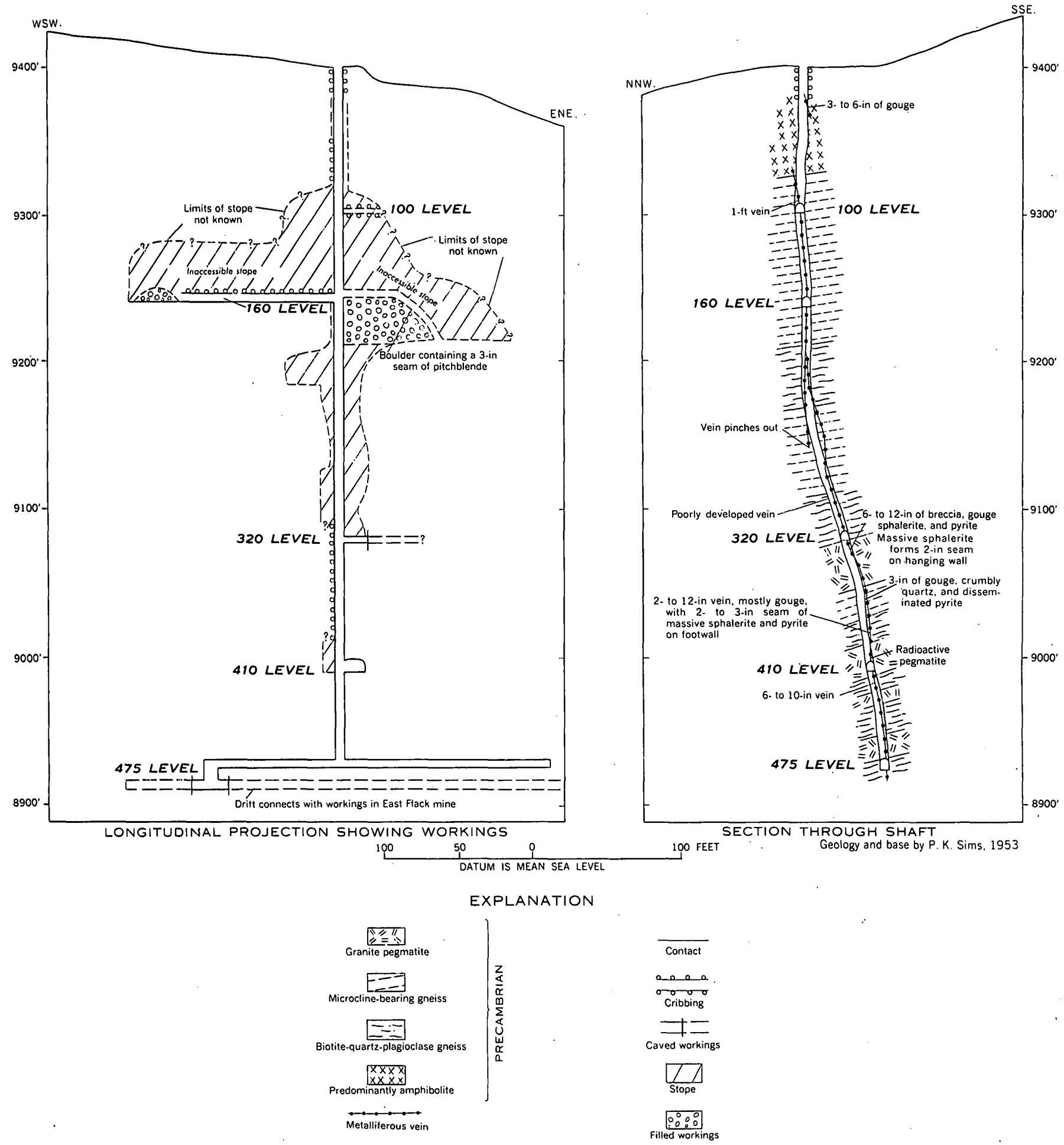

Figure 29.-Sections of the West Flack mine, Central City district.

a marked concentric layering (fig. 10) that was formed by pitchblende of slightly different color and reflectivity. Some grains have tiny quartz cores; others seem to have no foreign material at their ceriters. At places the grains are broken, partly rotated, and recemented by quartz. Tiny pellets of pitchblende (fig. 15), visible only under high magnification, are abundant in parts of the uranium-bearing ore. These pellets, commonly in 
aggregates, occur in quartz. The pitchblende was deposited before the other metallic minerals, and it was followed in order of formation by sphalerite, galena, and chalcopyrite. The sphalerite in the main vein is marmatite, but a red-brown variety which contains sparse chalcopyrite was noted in a branch vein from the 475 level. Much of the pyrite in the vein formed after deposition of galena, and it forms subhedral grains and veinlets, in part as fracture fillings. At places the pyrite is in delicate, lacy seams. Marcasite is locally intergrown with the late pyrite, and it also occurs as small, irregular, branching, crosscutting veinlets, and as thin coatings on pyrite crystals.

\section{MERCER COUNTY MINE}

The Mercer County (claim 732) mine, about 200 feet deep, is opened by a shaft that is inclined $80^{\circ} \mathrm{S}$. Prin- cipal levels are turned at vertical depths of 53,115 , and 159 feet. The stopes are shown in figure 30 .

The wallrock is microcline-bearing gneiss which contains sparse thin lenses and layers of biotite-quartzplagioclase gneiss and quartz-biotite schist. The rocks strike northeast and except locally, dip $15^{\circ}-45^{\circ} \mathrm{NW}$.

The vein strikes $\mathrm{N} .85^{\circ} \mathrm{E}$. and $\operatorname{dips} 80^{\circ} \mathrm{S}$. It consists of two or more subparallel vein fissures from a few inches to as much as 8 feet apart and steeply dipping connecting veins (figs. 30 and 31). The wallrock horses between the hanging-wall and footwall veins are altered and mineralized to varying degrees; where the two veins approach to within 2 or 3 feet of one another, the intervening rock is partly replaced by ore minerals to constitute minable ore. The ore consists largely of sphalerite and pyrite which occur in irregularly frac-
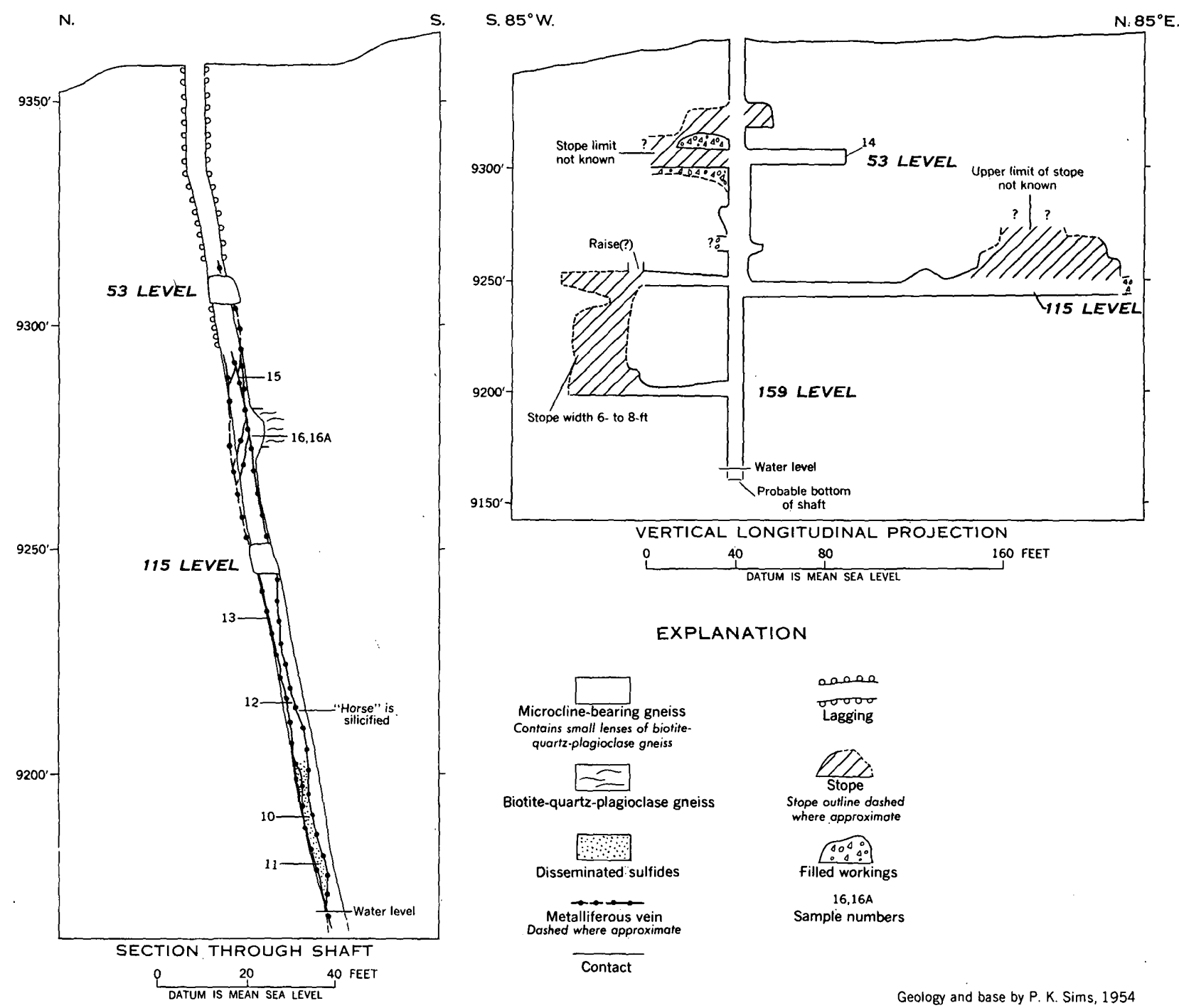

Figdre 30.-Sections of the Mercer County mine, Central city district. Sample data given tn table 17. 


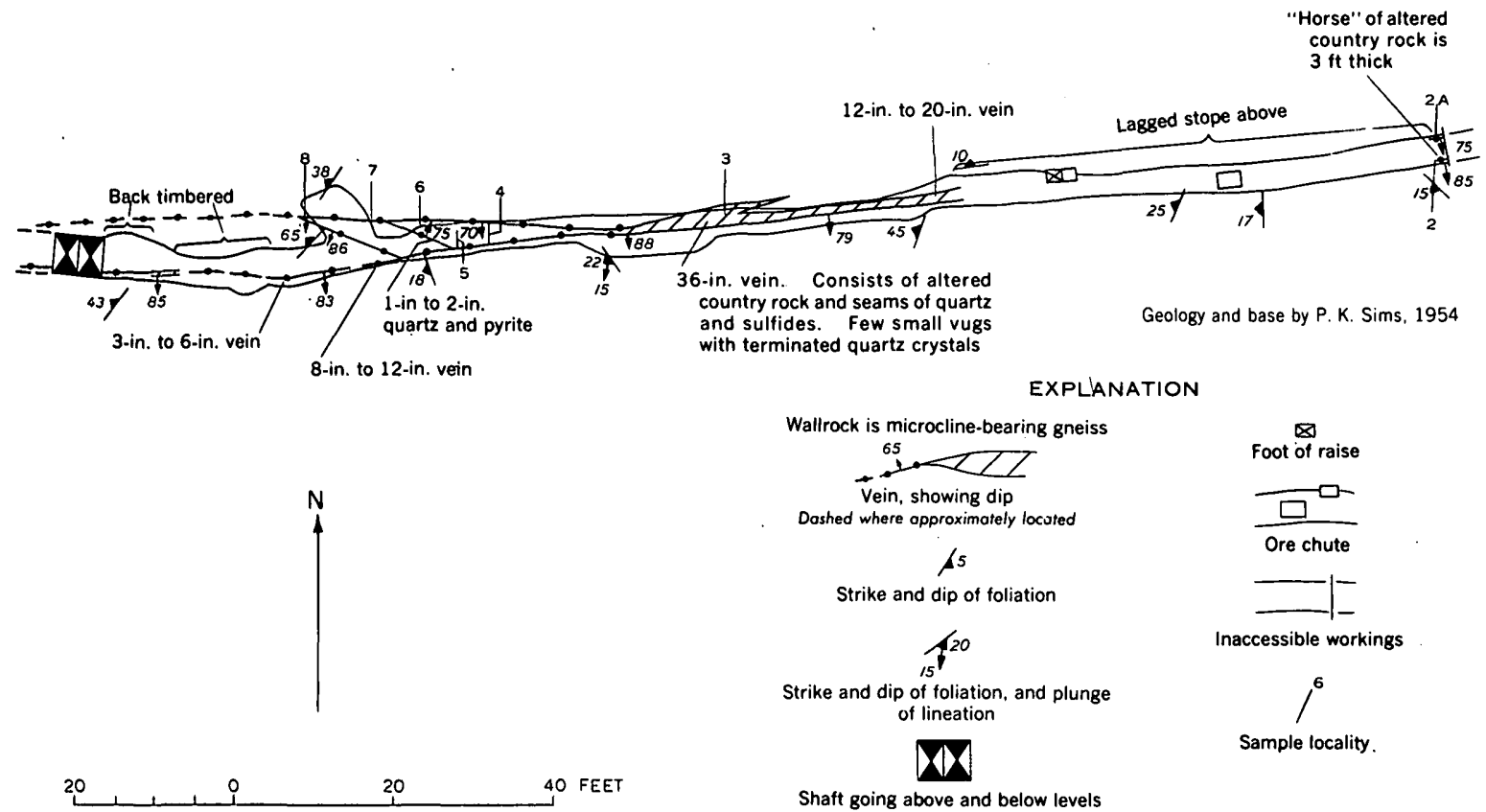

Fioure 31.-Geologic map of the 115 level, Mercer County mine, Central City distriet. Sample data given in table 17.

tured and altered country rock; a little white quartz at places is associated with the sulfide minerals.

The vein is oxidized, reddish-brown, soft, and crumbly to a depth of about 80 feet. Below this depth the vein is hard, the wallrock horses are silicified and sericitized, and the vein-forming minerals are unaltered.

Pyrite, the most abundant ore mineral, is disseminated through the altered wallrocks and forms clots in the veins. At places the pyrite vein is cut by thin stringers of sphalerite and galena, which commonly are less than 3 inches thick. Vugs that contain terminated white quartz crystals, pyrite cubes, and crystals of

TABLE 17.-Analyses from the Mercer County mine [A nalysos by U.S. Geol. Survey; analysts, S. P. Furman, E. C. Mallory, and James

\begin{tabular}{|c|c|c|c|c|c|c|c|c|}
\hline \multirow{2}{*}{ Samplo } & \multirow{2}{*}{$\begin{array}{c}\text { Width } \\
\text { (inches) }\end{array}$} & \multirow{2}{*}{$\begin{array}{l}\text { Equiv- } \\
\text { alent } \\
\text { ura- } \\
\text { nium } \\
\text { (per- } \\
\text { cent) }\end{array}$} & \multirow{2}{*}{$\begin{array}{l}\text { Ura- } \\
\text { nlum } \\
\text { (per- } \\
\text { cent) }\end{array}$} & \multicolumn{2}{|c|}{$\begin{array}{c}\text { Ounces per } \\
\text { ton }\end{array}$} & \multirow{2}{*}{$\begin{array}{c}\text { Copper } \\
\text { (per- } \\
\text { cent) }\end{array}$} & \multirow{2}{*}{$\begin{array}{l}\text { Lead } \\
\text { (per- } \\
\text { cent) }\end{array}$} & \multirow{2}{*}{$\begin{array}{l}\text { Zinc } \\
\text { (per- } \\
\text { cent) }\end{array}$} \\
\hline & & & & Gold & Silver & & & \\
\hline $\begin{array}{l}2 \ldots \\
3 \\
4 \\
4 \\
6\end{array}$ & $\begin{array}{r}10 \\
5 \\
36 \\
12 \\
18 \\
3 \\
14 \\
3 \\
22 \\
20 \\
12 \\
13 \\
10 \\
34 \\
15 \\
15\end{array}$ & $\begin{array}{l}0.007 \\
.002 \\
.001 \\
.002 \\
.002 \\
.002 \\
.005 \\
.002 \\
.003 \\
.002 \\
.005 \\
.003 \\
.002 \\
.002 \\
.002 \\
.003\end{array}$ & $\begin{array}{l}0.007 \\
\text { n.d. } \\
\text { n.d. } \\
\text { n.d. } \\
\text { n.d. } \\
\text { n.d. } \\
.003 \\
\text { n.d. } \\
\text { n.d. } \\
\text { n.d. } \\
\text {.002 } \\
\text { n.d. } \\
\text { n.d. } \\
\text { n.d. } \\
\text { n.d. } \\
\text { n.d. }\end{array}$ & $\begin{array}{c}0.02 \\
.14 \\
.36 \\
\mathrm{Tr} . \\
\mathrm{Tr} . \\
0 \\
\mathrm{Tr} . \\
.03 \\
\mathrm{Tr} . \\
.02 \\
\mathrm{Tr} . \\
\mathrm{Tr} . \\
.07 \\
.02 \\
.06 \\
\mathrm{Tr} .\end{array}$ & $\begin{array}{r}0.83 \\
1.70 \\
2.62 \\
.15 \\
.06 \\
0 \\
.13 \\
.22 \\
.04 \\
.24 \\
.01 \\
.11 \\
1.15 \\
.61 \\
.50 \\
.18\end{array}$ & $\begin{array}{l}0.10 \\
.12 \\
.76 \\
.01 \\
.01 \\
.01 \\
.01 \\
.01 \\
.01 \\
.01 \\
.01 \\
.01 \\
.03 \\
.03 \\
.02 \\
.01\end{array}$ & $\begin{array}{r}7.54 \\
4.14 \\
.37 \\
.05 \\
.07 \\
.03 \\
.04 \\
.04 \\
.03 \\
.03 \\
.02 \\
.03 \\
.63 \\
.14 \\
.12 \\
.06\end{array}$ & $\begin{array}{r}2.29 \\
.15 \\
.10 \\
.11 \\
.03 \\
.04 \\
.05 \\
.05 \\
.02 \\
.02 \\
.11 \\
.03 \\
.03 \\
.02 \\
.02 \\
.04\end{array}$ \\
\hline
\end{tabular}

n.d. means not determined. Tr. means trace. sphalerite are present at places. The sphalerite is dark red-brown marmatite.

The accessible parts of the vein were sampled by the Geological Survey, primarily to determine the uranium content but also to determine other ore values. It was hoped that uranium ore, possibly the source of the radon gas, could be found by systematic, close-spaced sampling, but uranium of ore grade was not found. The analyses are given in table 17 ; the locations of the samples are shown in figures 30 and 31 .

\section{GERMAN AND BELCHER MINES}

The German and Belcher mines, on the summit of Quartz Hill (pl. 4), are connected underground and have been worked together. Between 1909 and 1913 they yielded 16,160 pounds of pitchblende ore containing 1,822 pounds of $\mathrm{U}_{3} \mathrm{O}_{8}$ (table 1 ). In 1927, a small but unknown quantity of uranium ore was mined, and in 1933 about 1,000 pounds of ore was mined by a lessee, G. F. Grutzmacher. The uranium ore was hand sorted. The known output (metal contained in ore produced) of gold for 1891 and 1892 was 427 troy ounces; ${ }^{5}$ the recorded production for $1903,1909,1913-16,1918,1925$, and $1930-35$ was 1,178 tons of ore containing 628 troy ounces of gold, 1,530 ounces of silver, 14,371 pounds of copper, 182 pounds of lead, and 91 pounds of zinc. ${ }^{6}$

B Compiled from published annual reports of Director of the Mint. - Complled from U.S. Bureau of Mines records. Published by permission. 
The German mine was opened before 1887 and was worked sporadically until the middle thirties, but the Belcher mine probably was not opened before 1900 . Because the mines were known to have been a source of uranium ore, they were examined in 1944 by the Union Mines Development Corp. and in 1948 by G. Carman Ridland. In 1953 the German mine was rehabilitated under terms of a Defense Minerals Exploration Administration project. ${ }^{7}$ Sampling of the accessible workings was done largely by Ridland in 1948 and 1954; geologic mapping of the workings by the Geological Survey was done in April 1954.

The German shaft, inclined an average of $77^{\circ} \mathrm{S}$., is reported to be 600 feet deep (Bastin and Hill, 1917, p. 240), but it was caved below the 435 level in 1954 . Levels are present at vertical depths of $130,195,256$, 347,378 , and 435 feet. Presumably the 378 level is the 400 level of Bastin and the 435 level is the 500 level of Bastin (Bastin and Hill, 1917, p. 240). The Belcher shaft is inaccessible; however, it is known that the 120 level of the Belcher shaft connects with the stope above the German 130 level and that the Belcher 280 level connects with the German 256 level. Stoping in the German mine has been confined largely to the ground above the 130 level; the stoped ground in the Belcher mine is not accurately known, but probably is largely above the 120 level.

The wallrocks are principally microcline-bearing gneiss and biotite-quartz-plagioclase gneiss (pl. 5). The biotite gneiss that constitutes the wallrocks in the lower part of the mine is part of the continuous layer (pl. 4) that underlies Quartz Hill at shallow depths. The rocks are deformed into small gently arched, northeastward-trending anticlines and synclines that plunge northeast and southwest. Generally conformable bodies of pegmatite as much as a few tens of feet thick cut both rock types, and at places migmatite is formed by the intimate intercalation of pegmatite along foliation planes in the biotite gneiss. On the 435 level west, two small quartz bostonite porphyry dikes, which strike northwest and dip about $60^{\circ} \mathrm{NE}$., cut the Precambrian gneisses and in turn are cut and offset by the German vein. The larger dike is followed by a crosscut, now caved.

Two veins of opposing dip which intersect, the German-Belcher and the Last Chance-Burro, are developed in the German and Belcher mines; the intersection plunges about $17^{\circ} \mathrm{W}$., as shown on figure 27 . The Bushwacker vein of Bastin and Hill (1917, p. 241),

${ }^{7}$ Defense Minerals Exploration Administration docket 2878, German. Belcher mine, Gilpin County, Colo. (contract Idm-E501) which was cut in the crosscut on the 435 level west, is probably the Last Chance-Burro vein.

The German vein strikes N. $75^{\circ}-80^{\circ}$ E. and dips an average of $80^{\circ} \mathrm{S}$. East of its intersection with the Last Chance-Burro vein, however, the vein strikes more to the east than normal and dips slightly less. The vein is irregular and is characterized by many complexly branching vein fissures (pl. 5). At places it is a single well-defined structure as much as 20 inches wide, but more commonly it consists of subparallel or acutely diverging vein fissures that constitute a wide mineralized zone. Horses between splits in the vein are altered and contain disseminated pyrite. Shearing along the vein that took place after mineralization is slight. The wallrocks generally are intensely altered and at many places immediately adjacent to the vein it is difficult to distinguish between microcline-bearing gneiss and biotite-quartz-plagioclase gneiss wallrocks. Near the face on the 130 level east the vein is 1 foot wide and is surrounded by an 18-inch silicified and sericitized zone. This zone grades outward to 1 foot of argillized rock which, in turn, grades outward into fresh rock.

The Last Chance-Burro vein strikes more to the northeast than the German vein and dips steeply north (pl. 5). At the surface (pl. 4) it trends N. $65^{\circ}-70^{\circ}$ E. and dips $75^{\circ}-85^{\circ} \mathrm{NW}$. The calculated dip of the Burro vein from the surface to its intersection with the German vein in the German shaft is $80^{\circ} \mathrm{NW}$. Observations in the German-Belcher mine show that the Burro vein steepens near the intersection and reverses dip at places below the intersection.

Both the German and the Last Chance-Burro veins are pyrite veins that contain sphalerite, galena, and copper minerals; galena is sparse. Sphalerite, galena, chalcopyrite, and tennantite occur as stringers and lenses in quartz-pyrite vein material. Most of the veinlets are crosscutting and all are distinctly later than the pyrite and quartz. Commonly vugs containing terminated quartz crystals occur throughout the vein. At places stringers of white to tan chalcedonic quartz cut the sulfides. Pitchblende is a local constituent of the ores in the German vein; it is discussed separately below.

The ore that was shipped from the German and Belcher mines was taken entirely above the 256 level (fig. 27), and dominantly from a large stope above the 130 level. Systematic sampling of the accessible parts of the veins indicates that the unmined parts are low grade. The average content of 111 samples is 0.16 ounces of gold per ton and 1.32 ounces of silver per ton. Analyses of a few selected samples, the locations of which are shown on plate 5, are given in table 18 . 
Tant: 18.-Selected assays from the German mine ${ }^{3}$

\begin{tabular}{|c|c|c|c|c|c|}
\hline \multirow{2}{*}{ Sample } & \multirow{2}{*}{$\begin{array}{c}\text { Width } \\
\text { (inches) }\end{array}$} & \multicolumn{2}{|c|}{ Ounces per ton } & \multirow{2}{*}{$\begin{array}{c}\text { Copper } \\
\text { (percent) }\end{array}$} & \multirow{2}{*}{$\begin{array}{c}\text { Zinc } \\
\text { (percent) }\end{array}$} \\
\hline & & Gold & Silver & & \\
\hline $\begin{array}{l}29 \\
30 \\
73 \\
70 \\
01 \\
105 \\
110\end{array}$ & $\begin{array}{l}12 \\
20 \\
20 \\
22 \\
13 \\
20 \\
22\end{array}$ & $\begin{array}{l}0.08 \\
1.58 \\
.46 \\
2.09 \\
.06 \\
.18 \\
.04\end{array}$ & $\begin{array}{r}1.12 \\
2.30 \\
5.42 \\
2.32 \\
16.88 \\
9.36 \\
.08\end{array}$ & $\begin{array}{r}5.42 \\
4.55 \\
2.27\end{array}$ & $\begin{array}{r}8.04 \\
-9.39 \\
.60 \\
8.20 \\
.64 \\
1.01\end{array}$ \\
\hline
\end{tabular}

1 Semplos collectod by G. Carman Ridland Published by permission of Defense Minerals Exploratlon Administration. Location of samples shown on plate 5 .

The pitchblende produced from the German mine, so far as known, came entirely from the 130 level. Most of it probably came from the stope east of the shaft, but a piece of high-grade ore weighing 240 pounds that assayed 88 percent uranium oxide came from the 130 level west (Bastin and Hill, 1917, p. 241). Probably the uranium ore taken from the Belcher mine similarly came from the upper levels. Judging from published descriptions and the writers' observations, the pitchblende occurs as small lenses, containing from a few pounds to a few hundred pounds erratically distributed along the vein, and as discontinuous veinlets, from a fraction of an inch to about 4 inches wide.

Many veinlets are branches from the main vein into the walls, particularly the footwall; these veinlets, in addition to pitchblende, also contain white quartz and sparse sulfides. The ore mined in 1933 was a small lens of this type in the footwall. The veinlets and lenses generally are high in grade, but the grade of the ore produced from them has depended on the size and spacing of inclividual occurrences and on the care with which they were mined and subsequently hand sorted.

In 1954, pitchblende was observed in small veinlets erratically distributed in the footwall of the vein on the 130,195 , and 256 levels and in the stope above the 130 level, and as small remnants along the vein in the back of the stope. Analyses of samples taken in the mine, as locited in figure 27 , are given in tables 19 and 20 . The analyses show that the vein is abnormally radioactive along most of the length of the stope above the 130 level east and at scattered places on the level, but nearly all values are below 0.2 percent $\mathrm{U}_{3} \mathrm{O}_{8}$. The uranium is virtually in equilibrium; local disequilibrium can be accounted for largely by leaching in place by acid sulfate water after development of the mine. No abnormal radioactivity was detected below the 256 level. Bastin and Hill (1917, p. 242) report an analysis of 1.10 percent uranium oxide from the 500 level, presumably the 435 of this survey. This value could not be verified by the writers.
TABLE 19.-Uranium analyses from German mine 1

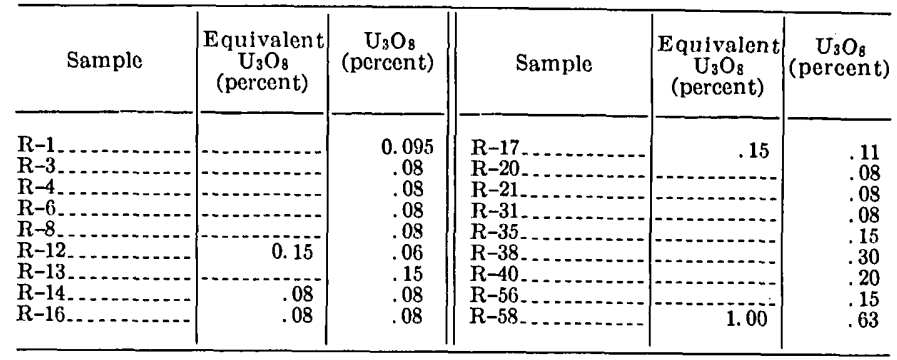

I Samples collected by G. Carman Ridland. Published by permission of Defense Minerals Exploration Administration. Location of samples shown in figure 27 .

TАВLе 20.-Uranium, gold, silver, lead, and zinc analyses from the German mine ${ }^{1}$

\begin{tabular}{|c|c|c|c|c|c|}
\hline \multirow{2}{*}{ Sample } & \multirow{2}{*}{$\begin{array}{c}\mathrm{U}_{3} \mathrm{O}_{8} \\
\text { (percent) }\end{array}$} & \multicolumn{2}{|c|}{ Ounces per ton } & \multirow{2}{*}{$\underset{\text { (percent) }}{\text { Lead }}$} & \multirow{2}{*}{$\begin{array}{c}\text { Zinc } \\
\text { (percent) }\end{array}$} \\
\hline & & Gold & Silver & & \\
\hline $\begin{array}{l}M-40 \\
M-41 \\
M-42 \\
M-43 \\
M-44 \\
M-45\end{array}$ & $\begin{array}{l}0.27 \\
.022 \\
.01 \\
.004 \\
2.57 \\
.39\end{array}$ & $\begin{array}{c}0.03 \\
.05 \\
<.005 \\
.005 \\
.11\end{array}$ & $\begin{array}{r}0.4 \\
<.2 \\
<.1 \\
.1 \\
2.7\end{array}$ & $\begin{array}{r}0.10 \\
.35 \\
.07 \\
.07 \\
.37\end{array}$ & $\begin{array}{r}0.37 \\
.80 \\
.05 \\
<.05 \\
.30 \\
. . .\end{array}$ \\
\hline
\end{tabular}

1 Published by permission of Defense Minerals Exploration Administration. Location of samples shown in figure 27 .

The study of four polished sections of pitchblendebearing ore taken from subsidiary veinlets on the 256 level east shows that the pitchblende is associated with quartz, minor amounts of pyrite, and sphalerite in discontinuous veinlets commonly less than one-eighth of an inch thick. Commonly the pitchblende forms discontinuous stringers $1 \mathrm{~mm}$ or more wide along the walls of the veinlets. At places pitchblende and quartz are interlayered, suggesting that they formed virtually contemporaneously. The pitchblende veinlets have spheroidal outlines; in part they consist of aggregates of rounded forms. In the sections studied, all the sulfides are later than the pitchblende.

Production of uranium ore from the German and Belcher mines is unlikely at present ore prices. In the German mine a few hundred pounds of high-grade ore could be mined selectively from erratic veinlets, mainly in the vein footwall, on the 3 upper levels and in the stope above the 130 level. Also, a few tons of low-grade ore, probably not exceeding about 0.15 percent uranium, and small quantities of high-grade ore could be extracted from the unmined ground above the 130 level (fig. 27). Possibly similar types and amounts of ore could also be mined from the Belcher mine, but opening the inaccessible workings would be costly.

\section{IRON MINE}

By A. A. DRAKE, JR.

The Iron - mine is in upper Russell Gulch, about three-fourths of a mile south of the East Calhoun 
mine. The shaft collar is at an altitude of 9,150 feet. In 1949, E. P. Beroni and H. C. Granger of the Geological Survey found pitchblende on the 300 level of the mine, about 524 feet west of the shaft, in a vein parallel to and 50 feet south of the Iron vein (fig. 32).

The Iron shaft is sunk on the dip of the Iron vein, and levels have been turned at vertical depths of 120 , $250,300,400,500,600$, and 700 feet. In 1954, only part of the 300 level was accessible.

The wallrock of the mine is Precambrian microclinebearing gneiss, amphibolite, and pegmatite. A bostonite porphyry dike of Tertiary age cuts the Precambrian rocks near the shaft on the 300 level and the 400 level (Bastin and Hill, 1917, p. 254). The wallrocks dip gently to the southeast and are deformed by crosswarps that plunge northward.

The Iron vein strikes east, dips on the average, steeply south, and ranges in width from a few inches to about 12 feet. The vein "horsetails" both to the east and to the west of the shaft. The Richardson and Grasshopper veins are the principal branches to the east, and the Bangor, Rocky Mountain Terror, and Becky Sharp are the main branches to the west. The Iron vein consists mainly of disseminations of pyrite along fractures in intensely altered gneiss, but locally this type of ore is traversed by a net of tiny pyritechalcopyrite-tennantite stringers. Less commonly several 1-inch-thick stringers of massive sulfide minerals cut the disseminated ore. Vugs and fractures in the vein are commonly filled by light tan to gray finegrained quartz.

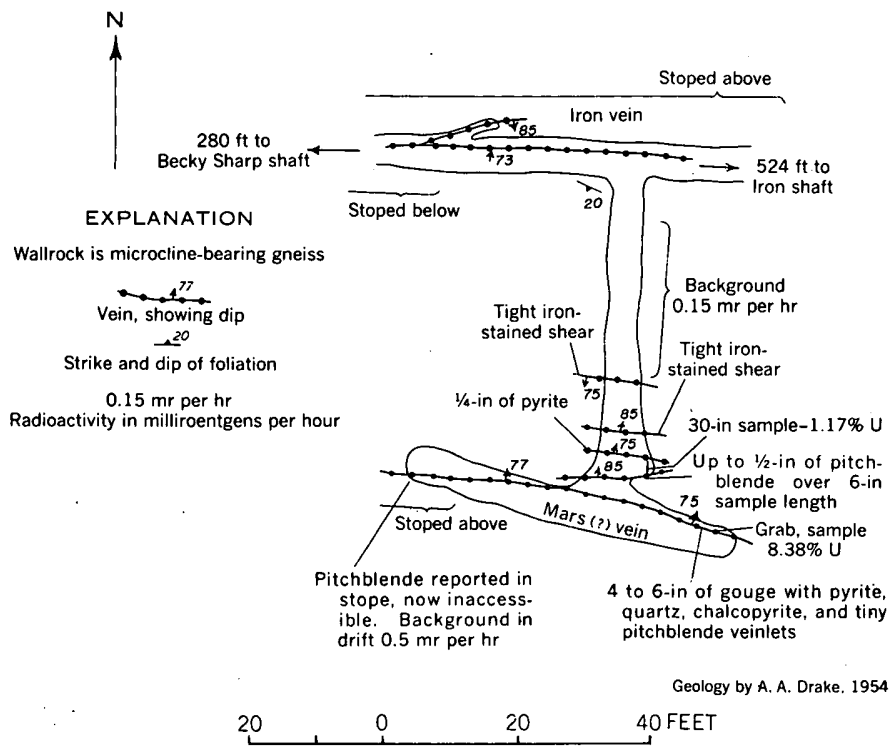

Figdre 32.-Geologic map of part of the 300 level, Iron mine, showing pitchblende occurrences.
The pitchblende occurs in a vein tentatively identified as the Mars vein and in minor veinlets that branch from the Mars vein into the hanging wall (fig. 32). The Mars (?) vein strikes N. $80^{\circ}$ W., dips $75^{\circ}$ N., and consists mainly of pyrite, quartz, chalcopyrite, and locally pitchblende. The pitchblende occurs in discontinuous veinlets as much as a quarter of an inch wide that are fractured and locally brecciated. Rarely, the breccia fragments have been streaked out into lens-shaped masses. The pitchblende is dull and black. Although it appears massive in hand specimens, it is seen under the reflecting microscope to occur as colloform masses. Shrinkage cracks that are perpendicular to the spheroidal surfaces are common. A few small rounded forms have cores of pyrite. The pitchblende is cut by a later generation of pyrite veinlets.

Two samples cut across the pitchblende veins (fig. 32) assayed 8.38 and 1.17 percent uranium. Ray $\mathbf{A}$. Bennett (oral communication, 1954) reports that goodgrade pitchblende ore is exposed in the small stope at the west end of the Mars drift, but as this stope was inaccessible in 1954, the writer could not check this reported occurrence.

\section{JEFFERSON-CALHOUN VEIN}

Small quantities of pitchblende have been found in the Jefferson-Calhoun vein at the West Calhoun and East Calhoun mines; the substantiated production is 90 pounds of $\mathrm{U}_{3} \mathrm{O}_{8}$ from the West Calhoun mine (table 1 ).

The Jefferson-Calhoun vein is a prominent east-northeastward-trending structure which has been mined and prospected along a length of more than 3,000 feet (pl. 4). The mines on the vein from northeast to southwest are the East Calhoun (altitude 9,290 feet), Gold King (altitude 9,310 feet), West Calhoun (altitude 9,390 feet), Kemp-Calhoun (altitude 9,441 feet), and Jefferson-Calhoun (altitude 9,490 feet). West of the Jefferson-Calhoun shaft, the vein either joins with another vein or splits into two segments, which were mined in the' Delaware and Prompt Pay mines. The accessible workings in the East Calhoun mine were mapped by Drake (1957) in 1952-53, and part of the West Calhoun mine was examined earlier by Moore and Butler (1952).

The Jefferson-Calhoun vein strikes N. $65^{\circ}-70^{\circ} \mathrm{E}$. It dips about $70^{\circ} \mathrm{SE}$. at the East Calhoun mine but steepens to nearly $90^{\circ}$ in the West Calhoun, KempCalhoun, and Jefferson-Calhoun mines. The vein is a pyrite vein that contains galena, sphalerite, and copper minerals, but there are conspicuous changes in the proportions of the primary metallic minerals along its strike. At the East Calhoun mine the vein consists primarily of pyritized and silicified wallrock, pyrite, and quartz, with spotty chalcopyrite and sphalerite (Drake, 1957). To the southwest in the West Calhoun mine 
sphalerite in particular is more abundant and widespread in the vein, and pyrite is less prominent.

Moore and Butler $(1952$, p. 7$)$ observed pitchblende at two places in the accessible workings of the West Calhoun mine:

At the 245-foot level, Just east of the shaft, an area about 1-foot square on the wall has a dark coating of pitchblende. This conting shows no other minerals. At the 387 -foot level, 70 feet west of the shaft, pitchblende is found in a pyrite stringer one-eighth inch wide that extends several feet along the wall of the drift.

The latter occurrence is thought by Moore and Butler to be near the stope from which the high-grade pitchblende ore was extracted.

At the East Calhoun mine, Moore and Butler (1952, p. 7 ) found 2 small occurrences of sooty pitchblende on the 131 level, 1 near the shaft and the other near the intersection of the Calhoun and Wood veins.

Bastin and Hill (1917, p. 247) describe a specimen, furnished by P. R. Alsdorf, of high-grade pitchblende ore from 45 feet west of the West Calhoun shaft on the 387 level; the specimen shows brecciated pitchblende cut by many veinlets composed of pyrite, sphalerite, quartz, and galena. Another specimen, taken 50 feet west of the shaft on the same level, consists of a $1 / 8$ - to $3 / 16$-inch veinlet of pitchblende that cuts altered schist wallrock. Bastin and Hill describe a polished section of this ore in which the pitchblende was in places shattered and cemented by galena, sphalerite, chalcopyrite, and gray quartz, and in other places was cut by veinlets of galena. A specimen shown to one of the writers by R. R. Hinckley consists of botryoidal pitchblende coated by an eighth of an inch of marcasite.

\section{RIRR MINE}

The Kirk mine, on the upper part of Quartz Hill at an altitude of 9,460 feet (pl. 4), has been 1 of the 2 main sources of pitchblende in the region. The substantiated production of uranium ore is 170 tons that contained 22,490 pounds of $\mathrm{U}_{3} \mathrm{O}_{8}$ (table 1 ). Some additional ore was produced during 1897 to 1900 , but the quantity is not known. As the mine was inaccessible from 1951 to 1956 , the description that follows was taken from the available data obtained earlier from the mine (principally from G. B. Guillotte and J. M. Hill, written communication, 1945).

The mine probably was opened originally in search of gold sometime during the late 1800's. The earliest production was from the Discovery shaft. A large amount of pitchblende was mined from the shaft, but as the miners did not recognize the pitchblende in the ore, the uranium was lost in an attempted treatment for gold (Moore and Kithil, 1913, p. 43-44). By the time the pitchblende was recognized the gold values had dropped, and accordingly these workings were abandoned and a new shaft, the Kirk shaft, was started 190 feet to the west. In 1897 and 1898 and again in 1905 and 1906 considerable pitchblende ore was mined from this shaft, but for several years afterward the operators were largely concerned with gold ore. In 1914 uranium ore was again shipped. During the 1930 's the mine was worked largely for gold, but scattered small kidneys of pitchblende were found, most of which were sold as specimens. The recorded production exclusive of uranium for 1905-12, 1931, and 1937-39 was 863 troy ounces of gold, 4,580 ounces of silver, 16,093 pounds of copper, 541 pounds of lead, and 525 pounds of zinc. ${ }^{8}$

The mine workings consist of three shafts-Kirk shaft, Discovery shaft, and East shaft (pl. 6)-and short levels from the Kirk shaft at vertical depths of $88,141,203,239,301$, and 381 feet (pl. 6). With the exception of the workings from the Discovery shaft, which were caved, the mine was examined and sampled in 1944 by Guillotte and Hill. As this survey was primarily to evaluate the mine as a potential source of uranium ore, they obtained much information concerning grade but made few observations concerning the geologic relations of the pitchblende-bearing ore.

The Kirk vein strikes $\mathrm{N} .70^{\circ}-75^{\circ} \mathrm{E}$., dips an average of about $75^{\circ} \mathrm{SE}$., and can be traced at the surface for at least 1,400 feet (pl. 4). The vein cuts microclinebearing gneiss and biotite-quartz-plagioclase gneiss. Two northwestward-trending quartz bostonite porphyry dikes crop out sporadically at the surface west of the main shaft (pl. 4), and several quartz bostonite porphyry dikes were cut on several levels of the mine.

The Kirk vein occupies a zone of intense fracturing and ranges in width from less than 1 foot to about 6 feet. It consists of gray quartz, abundant pyrite, some chalcopyrite and tennantite, and scattered sphalerite and galena; secondary (?) chalcocite is reported in the ore to depths of at least 141 feet. The wallrocks are sericitized, silicified, and impregnated with small cubes of pyrite. The metallic minerals form erratic stringers from half an inch to about 1 foot wide, which at places are frozen to the walls and at other places occur in the altered wallrock. Gouge-filled fractures that formed after ore deposition occur on the walls or cross from one wall to the other. Guillotte and Hill (written communication; 1945) state that the vein is well developed in microcline-bearing gneiss wallrocks but is poorly developed in "schist". On the 141 level, 100 feet east of the main shaft, the Kirk vein is crossed by a vein that strikes $\mathrm{N} .78^{\circ} \mathrm{E}$. and dips $80^{\circ} \mathrm{S}$; possibly

${ }^{8}$ Complled from U.S. Bureau of Mines records. Published by permission. 
the same intersection was encountered on the 301 and 381 levels east.

Detailed sampling of the mine by Guillotte and Hill shows that the exposed parts of the vein commonly contain sparse gold (pl. 6). Most samples that were taken contained less than 0.2 ounce of gold per ton, and only two samples assayed more then 1 ounce of gold per ton. In general, the gold content of the exposed vein is slightly higher in the ground adjacent to the East shaft.

Judging from the distribution of stopes in the mine (pl. 6), three separate gold-bearing ore shoots, which locally contained pitchblende ore, were mined. The largest shoot plunges steeply west from just below the 141 level to the 381 level and probably below. The stopes on this shoot are rarely as much as 3 feet wide and at places are only 1 foot wide (Guillotte and Hill, written communication, 1945). In the upper part of this body the vein dips $75^{\circ} \mathrm{SE}$. or less, whereas on the 381 level it is nearly $90^{\circ}$. Another large stope is on the south vein above the 141 level, beginning 50 feet east of the main shaft and extending 50 feet beyond the east shaft. The vein dips steeply south and is 1 to 3 feet thick. A third stope is above the 141 level on the north vein. This stope is 6 to 8 feet wide, but according to Guillotte and Hill (written communication, 1945) the vein is only 4 to 6 inches wide; the rest of the stoped ground consists largely of soft altered microcline-bearing gneiss. The small stopes west of the main shaft above the 381 level are on small lenses of sulfide-bearing ore in partly silicified wallrock. The stope is 1 to 4 feet wide; the sulfide ore pinches to the west. The extent of mining from the Discovery shaft is not known, nor is it known which of the two veins in this area was mined.

The uranium ore in the Kirk vein occurs wholly as pitchblende. Aside from small quantities of zippeite (?) on mine timbers and torbernite as local coatings on wallrocks, both forming after development of the mine, there are no secondary uranium minerals. The pitchblende occurs in relatively small masses sporadically distributed through the vein. Previous accounts indicate that the pitchblende is in small lenses, stringers, and kidneys, generally adjacent to the country rock on the hanging wall. At places this rich ore is as much as 1 foot thick; one piece was removed that measured 2 feet 8 inches by 1 foot 4 inches by 1 foot (Moore and Kithil, 1913, p. 44). According to Moore and Kithil (1913, p. 44), the pitchblende masses were separated from one another by nonuraniferous material. The ore that was mined generally was high in grade, and some of it assayed 60 to 80 percent $\mathrm{U}_{3} \mathrm{O}_{3}$ (Moore and Kithil, 1913, p. 44). The description and assay data presented by Guillotte and Hill indicate (written communication, 1945) that pitchblende also is in small discontinuous stringers, many of which cannot be recognized with the naked eye. Although some of these seams are in the walls, most apparently occur within the sulfide-bearing vein material.

The detailed sampling by Guillotte and Hill shows that the uranium-bearing parts of the vein occur predominantly in the upper workings. The locations where samples were taken, and where pitchblende was observed in place are shown on plate 6 . On the 65 level of the East shaft a segment of the Kirk vein more than 10 feet long, averaging 3.6 feet in width, contains an average of 1.05 percent $\mathrm{U}_{3} \mathrm{O}_{8}$. Pitchblende was observed nearby in the shaft both above and below the level. Pitchblende also was seen above the cave in the Discovery shaft, and at one place in the stope between the 141 and 203 levels.

The pitchblende has a botryoidal form and at places this form is visible in hand specimens. A specimen taken from the 381 level of the mine by R. R. Hinckley consists of botryoidal forms as much as half an inch across. A polished section of pitchblende-bearing ore, prepared from a specimen given by Hinckley, shows that the pitchblende is fractured and veined by pyrite and quartz (fig. 21). Polished surfaces of pitchblende studied by D. R. George and described by Guillotte and Hill, were similar to the one studied by the writers. George noted that the pitchblende occurs as (1) large pure rounded masses having a mottled light and dark color and typically a well-defined botyroidal structure; (2) highly factured, irregularly shaped fragments of varying size intimately associated with quartz and sulfide minerals; and (3) thin irregular veinlets cutting the quartz gangue. He found that all the other metallic minerals in the ore-pyrite, chalcopyrite, sphalerite, tennantite, and galena-aside from some of the pyrite, cut the pitchblende. He states that the chalcopyrite in the Kirk ores is distinctly later than the pitchblende. The paragenetic sequence observed by George is: quartz, pyrite, pitchblende, pyrite, quartz, sphaleritechalcopyrite-tennantite-galena, chalcopyrite.

The ground believed by the writers to be most favorable for the production of small quantites of uranium ore is above the 141 level, between the Discovery and East shafts. (See pl. 6.) Some ore is exposed in the back of the 65 level of the East shaft. In exploration of this ground the extent of the workings from the Discovery shaft was not known. The ground between the 141 and 301 levels is probably also favorable for concentrations of ore grade and could be explored by raising from the face of the 301 level. Although some uranium ore might be found by exploring the ground 
below the 381 level along the rake of the ore body stoped near the shaft, the quantity of ore would probably not be sufficient to pay the mining costs.

\section{OLD TOWN MINE}

By A. A. DRAKE, JR.

The Old Town mine, in upper Russell Gulch at an altitude of 9,143 feet, is about 430 feet N. $40^{\circ}$ W. from the Iron shaft. The property was located in the late 1880 's and has been operated intermittently since then. Pitchblende was discovered underground in 1952 by J. D. Wells and A. E. Dearth of the Geological Survey; so far as known, there is no abnormally radioactive material on the dump.

Production from the Old Town mine for the years of reported activity, 1902-21 and 1924-44, was 214,412 tons of ore containing 108,949 troy ounces of gold, 285,661 ounces of silver, $1,945,391$ pounds of copper, 6,705 pounds of lead, and 10,077 pounds of zinc. ${ }^{9}$

The mine is opened by a 2,205-foot inclined shaft that follows the vein. Twenty-one principal levels and two sublevels have been driven from the shaft. The 22d level, or: Hot: Time lateral, connects with the Argo tunnel. Much stoping has been done above the 16th level. In 1954, only parts of the fourth, fifth, sixth, new sixth, six-fifty, and seventh levels were accessible.

The wallrock is largely microcline-bearing gneiss. A layer of sillimanitic biotite-quartz gneiss, which lies above microcline-bearing gneiss, occurs above the second level, and a layer of biotite-quartz-plagioclase gneiss occurs between the new sixth and ninth levels. The layer of biotite-quartz-plagioclase gneiss probably correlates with the 250-foot thick layer that underlies Quartz Fill at shallow depths (pl. 4). Except locally, the wallrocks dip gently southeast.

o Complled from U.S. Burenu of Mines records. Published hy permission.
The Old Town vein, one of the largest and most productive veins of the Central City district, strikes on the average about $\mathrm{N} .60^{\circ} \mathrm{E}$. and $\operatorname{dips} 35^{\circ}-50^{\circ} \mathrm{NW}$. It ranges in width from 1 to about 8 feet and averages 3 feet in width. The vein occupies a low-angle fault that was formed during the early Laramide period of faulting.

The vein consists largely of intensely fractured and sericitized wallrock which is locally referred to by the miners as "talc" ore. This material is impregnated with pyrite and cut by $1 / 4^{-}$to $11 / 2$-inch veinlets of pyrite and chalcopyrite. According to John Anderly (oral communication, 1952), a former miner at the Old Town mine, gold and silver values varied directly with the amount of copper in the ore.

Pitchblende is present on the sixth, new sixth, and seventh levels of the mine, and in the shaft 20 feet above the seventh level (fig. 33). Harvey Jacobson (oral communication, 1952) reports that anomalous radioactivity also is present on the 11th level. The pitchblende occurs in tiny, $1 / 4$-inch veinlets in silicified rock in the walls of the Old Town vein. The veinlets 20 feet west of the shaft on the sixth level and above the seventh level are in "horses" between footwall and hanging-wall branches of the Old Town vein, and their attitude and lenticular character suggest that they fill gash fractures formed by tensional stresses. The veinlets on the new sixth level are in the footwall of the Old Town vein and also appear to occupy gash fractures. The other veinlets, in the footwall of the Old Town vein, fill narrow fractures that nearly parallel the Old Town vein.

The pitchblende observed in the mine is soft and sooty, and it has been leached (table 21). The pitchblende is very much out of equilibrium, and much of the radioactivity is caused by radium; more than 90 percent of the uranium has been leached from samples OT- 3 and OT-4. The writer infers that the leaching was done after mining by acid sulfate ground water.

'I'ABLE, 21.-Uranium analyses from the old Town mine

[Analyses by U.S. Geol. Survey, analysts: John Rosholt, S. P. Furman, Wayne Mountjoy and J. P. Schuch.]

\begin{tabular}{|c|c|c|c|c|c|c|c|c|c|c|}
\hline \multirow{2}{*}{ Samplo : } & \multirow{2}{*}{ Location } & \multirow{2}{*}{$\begin{array}{l}\text { Thickness } \\
\text { of pitch- } \\
\text { blende } \\
\text { veinlet } \\
\text { (inches) }\end{array}$} & \multirow{2}{*}{ Description } & \multirow{2}{*}{$\underset{\text { (percent) }}{\text { Equivalent }}$} & \multirow{2}{*}{$\begin{array}{r}\text { Uranium } \\
\text { (percent) }\end{array}$} & \multicolumn{5}{|c|}{$10^{\circ}$ Curies per gram of sample } \\
\hline & & & & & & $\mathrm{Rn}$ & RaD & $\mathrm{Ra}$ & $T_{h}^{230}$ & $\mathrm{~Pb}^{210}$ \\
\hline o'T-1... & $\begin{array}{l}\text { 0th level west, } 20 \text { ft from shaft } \\
\text { near sill. }\end{array}$ & 0.25 & $\begin{array}{l}\text { Strongly silicified horse between } \\
\text { Old Town footwall and hang- }\end{array}$ & 0.92 & 0.21 & 4. 51 & 5. 65 & 6.55 & & \\
\hline $\mathrm{O}^{\prime} \mathrm{T}-2 \ldots . .$. & 6th level west, 87 ft from shaft. & .06 & $\begin{array}{l}\text { ing-wall veins. } \\
\text { Silicified footwall of old Town }\end{array}$ & .01 & .016 & & & & & \\
\hline $\mathrm{O}^{\prime} \mathrm{T}-3 .$. & 7th level west, 37 ft from shaft, & .25 & $\begin{array}{l}\text { vein. } \\
\text { Silicified footwall of Old Town }\end{array}$ & 4.50 & .12 & 31.3 & 28.0 & 42.5 & & \\
\hline O'T-4........... & Now 6th level east, 424 ft from & .25 & $\begin{array}{l}\text { vein. } \\
\text { Footwall of Old Town vein.... }\end{array}$ & .28 & .01 & 2.1 & & 2.3 & 0.066 & 1.8 \\
\hline O'ग-5... & Shaft, 20 ft above 7 th level.... & 25 & $\begin{array}{l}\text { Between hanging-wall and foot- } \\
\text { wall branches of Old Town vein. }\end{array}$ & .64 & .42 & 3.2 & & $\begin{array}{l}3.2 \\
0\end{array}$ & 1.5 & 3.1 \\
\hline
\end{tabular}

1 Sample localitics shown in figure 33. 

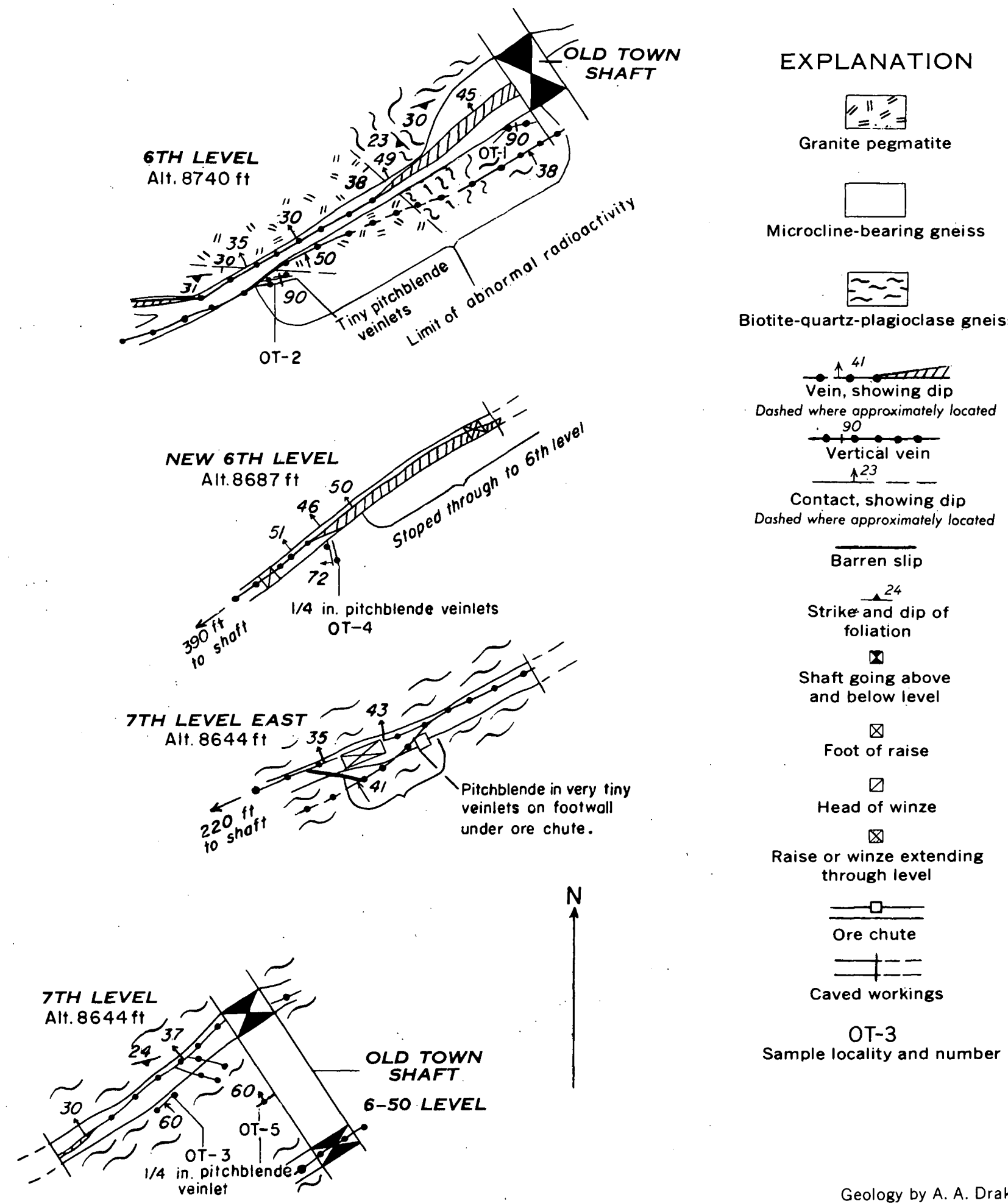

\section{EXPLANATION}

$$
\angle 11=
$$

Granite pegmatite

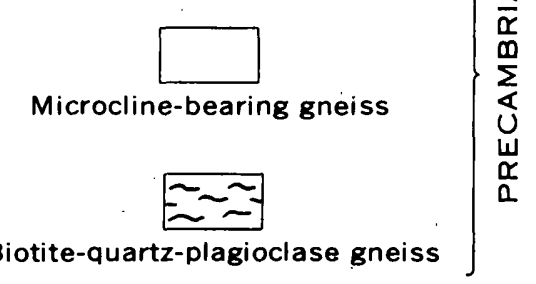

$$
\begin{aligned}
& \text { Vein, showing dip } \\
& \text { Dashed where approximately located } \\
& \rightarrow \text { Vertical vein } \\
& 123 \\
& 24 \\
& \text { Da }
\end{aligned}
$$

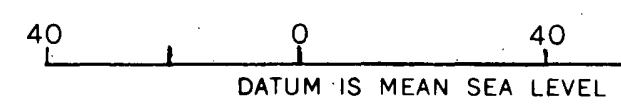

Geology by A. A. Drake, 1952 80 FEET

Figure 33.-Geologic maps showing pitchblende occurrence, Old Town mine, Central City district. Sample data given in table 21. 


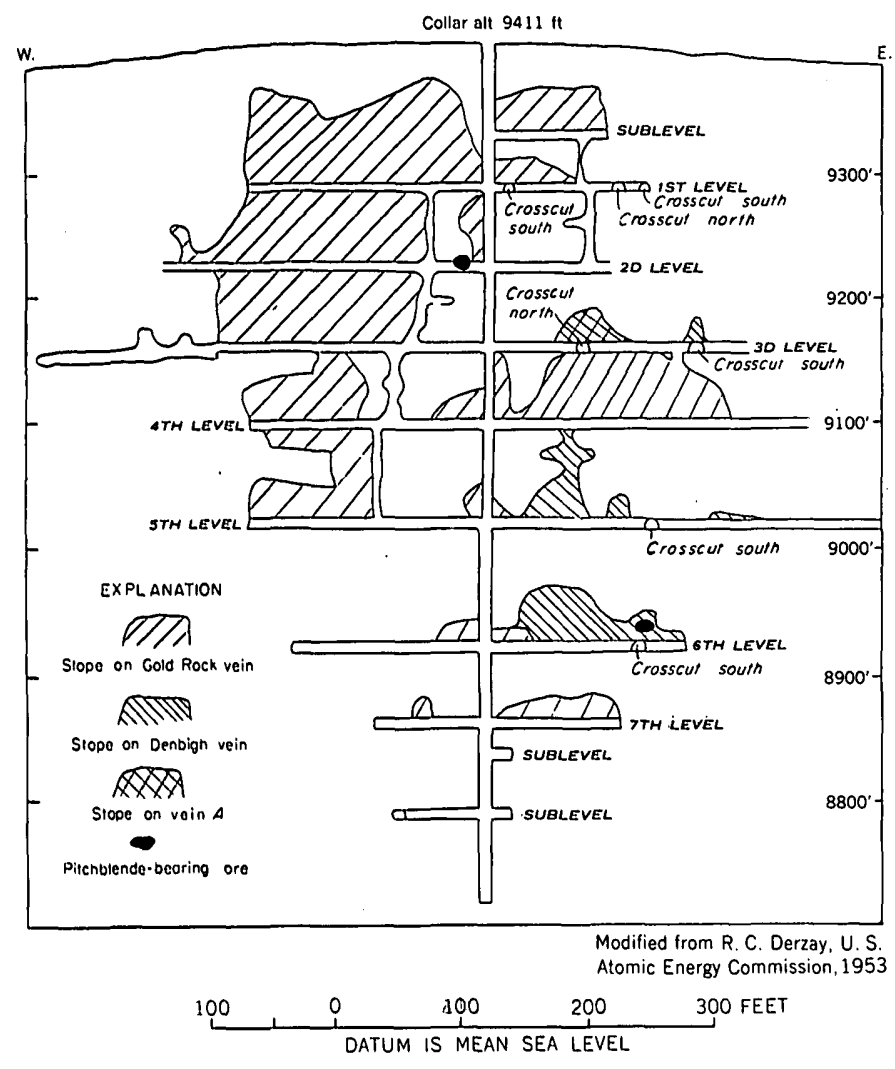

Prourn 34.-Vertical longltudinal projection of the Springdale mine Central City district.

SPRINGDALE (GOLD ROCK) MINE

By A. A. DRAKE, JR.

The Springdale mine, near the head of upper Russell Gulch at an altitude of 9,411 feet, is about 3,600 feet N. $83^{\circ} \mathrm{W}$. from the Old Torvn shaft. Pitchblende was first noted on the dump of the mine in 1949, and the mine and shaft were partly rehabilitated in 1952 . In the following year the U.S. Atomic Energy Commission granted the operator an exploration contract. As minable quantities of pitchblende were not developed during the rehabilitation and exploration, the mine was closed in 1953.

The recorded production from the Springdale mine for the year's of reported activity, 1907, 1910, 1912-15, $1917,1920-21,1929$ and 1934 , was 725 tons of ore containing 339 troy ounces of gold, 2,057 ounces of silver, 7,558 pounds of copper, 584 pounds of lead, and 1,375 pounds of zinc. ${ }^{10}$ Some pitchblende was mined from the stope above the sixth level, but it probably was discarded as waste.

The Springdale mine is opened by a nearly vertical 685 -foot shaft from which 7 levels and 3 sublevels have been turned (fig. 34). At the time of the present study

${ }^{10}$ Complled from U.S. Burenu of Mines records. Published by permission.
(1952-53) only parts of the second, third, fourth, fifth, and sixth levels were accessible for mapping. R. C. Derzay of the Atomic Energy Commission examined all the workings, however, for andioactivity (written communication, 1953).

The Springdale shaft is collared in biotite-quartzplagioclase gneiss, but microcline-bearing gneiss is cut about 20 feet below the second level and this rock persists to the bottom of the shaft. Several thin layers of biotite-quartz-plagioclase gneiss, migmatite, and pegmatite occur locally in the microcline-bearing gneiss. The Precambrian rocks are cut by a persistent dike of bostonite porphyry. As the mine is on the northwest flank of the Central City anticline, the rocks generally dip moderately to the northwest, but locally they are deformed by small northward-trending crosswarps. The bostonite porphyry dike strikes about N. $70^{\circ} \mathrm{E}$. and dips steeply to the south.

The Springdale mine develops the Gold Rock and Denbigh veins, which intersect, and several minor veins. The Gold Rock vein ranges in strike from N. $60^{\circ} \mathrm{E}$. to east, dips steeply either side of $90^{\circ}$, and is characterized by many horsetail and looping branches. It consists largely of gouge that contains disseminated pyrite and sparse base-metal sulfides. Typically the vein is 2 to 3 feet wide and contains 2 - to 4 -inch stringers of quartz and pyrite that are cut by $1 / 8$ - to 2 -inch stringers of galena, sphalerite, and chalcopyrite. A uraniumbearing pod that has a strike length of 13 feet, a width of $1 / 16$ to 4 inches, and a height of 2 feet, was found in the vein on the second level, about 12 feet west of the shaft (fig. 34). The uranium mineral in this pod is black, occurs as sooty encrustations on fractures, and probably is pitchblende. An autoradiograph of a specimen indicated that the radioactivity is localized in small specks.

The Denbigh vein strikes about N. $60^{\circ}$ E., dips steeply either side of $90^{\circ}$, and ranges in width from 2 inches to about 4 feet. Branches are absent except on the fifth level near the intersection with the Gold Rock vein. The vein consists largely of milky white to gray finegrained quartz with $1 / 16^{-}$to 4 -inch stringers of pyrite. The quartz-pyrite vein is crosscut by $1 / 8$ - to 4 -inch veinlets of galena, sphalerite, chalcopyrite, and tennantite. Pitchblende was found 15 feet up in a stope on the sixth level about 25 feet west of the crosscut from the Gold Rock vein (fig. 34). The pitchblende occurs in a pod that rakes about $60^{\circ} \mathrm{W}$. and has a stope length of 10-12 feet, a rake length of 14 feet, and a maximum width of 3 feet. Within the pod, the hard, black, lustrous pitchblende fills $1 / 2$ - to 4 -inch subparallel discontinuous veinlets on the southeast wall of the vein (fig. 35). It occurs both in microcline-bearing gneiss and bostonite 

N. $20^{\circ} \mathrm{W}$.
S. $20^{\circ} \mathrm{E}$.

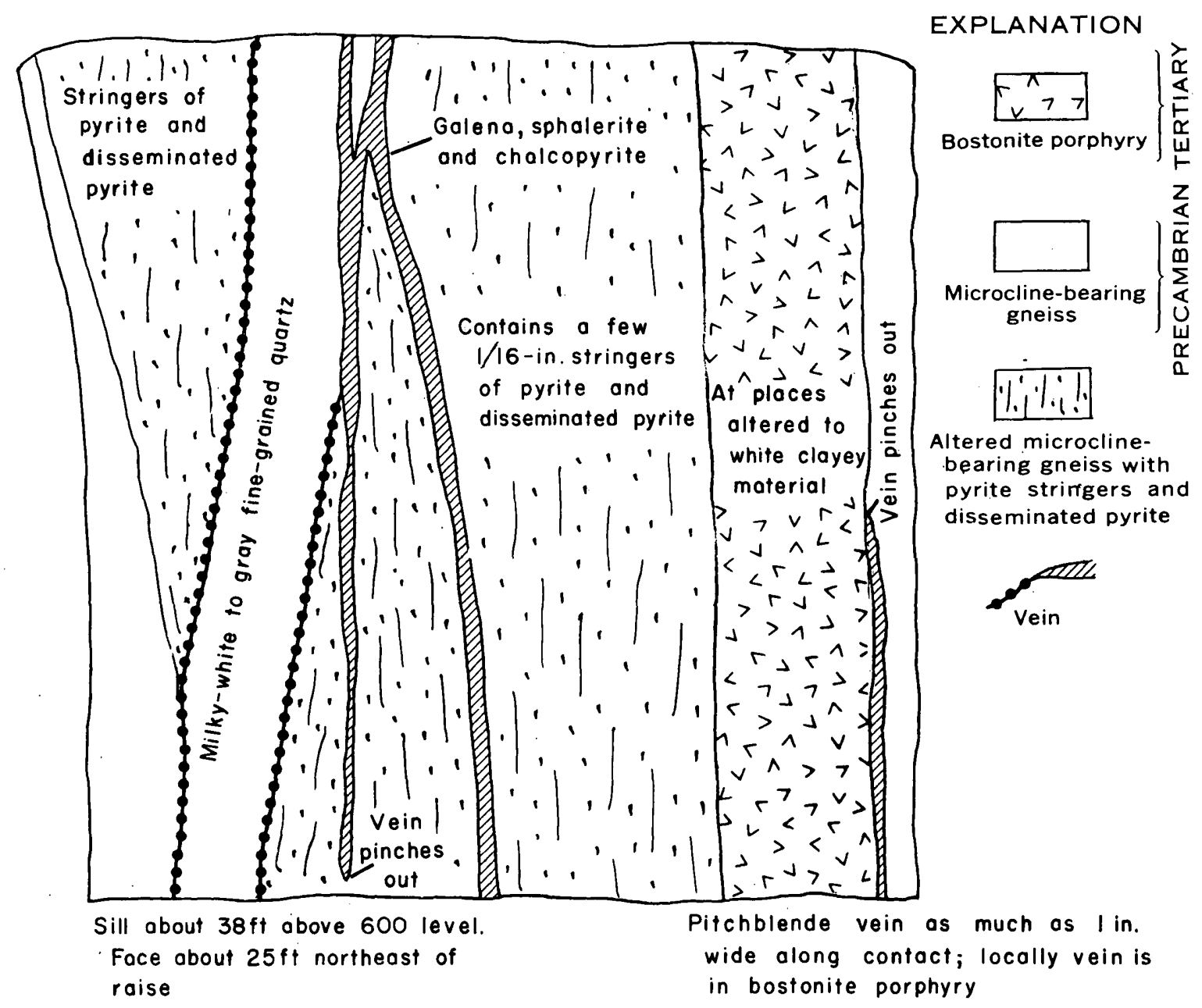

Geology by P. K. Sims, 1953

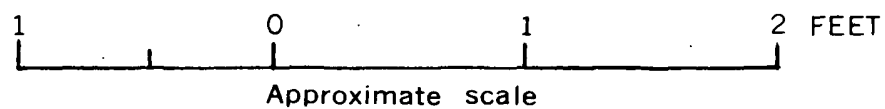

Figure 35.-Geologic section of stope face, Denbigh vein, sixth level, Springdale mine.

porphyry wallrocks. The pitchblende veinlets are cut by the base-metal sulfide veinlets.

Under the reflecting microscope the pitchblende is seen to consist of spheroidal forms from less than 0.1 to $3 \mathrm{~mm}$ in diameter. The small forms appear as tiny pellets; slightly larger grains have outer curved surfaces, suggesting colloform growth. Some of the pelletlike forms contain cores of quartz. The pitchblende at places is brecciated, and fragments commonly are rotated; at other places the pitchblende is fractured but not brecciated. The breccia fragments are generally angular and are healed by quartz which contains scattered generally euhedral pyrite crystals. Both quartz and pyrite vein the pitchblende; commonly they occur in the same vein and appear essentially contemporaneous with the pitchblende.

\section{TELEGRAPH MINE}

The Telegraph mine is on Quartz Hill, 2,500 feet eastnortheast of the Wood shaft. The shaft collar is at an altitude of 9,090 feet. In 1954, a small quantity of pitchblende was found on the dump, and during 1955 the mine was rehabilitated to a depth of 170 feet; no uranium ore has been shipped (as of 1955).

The known mine workings consist of a 2-compartment shaft, inclined $80^{\circ}-85^{\circ} \mathrm{S}$., and a short level at a depth of 170 feet. A stope, possibly 50 feet high and 60 feet long, is present west of the shaft above the 170 
level. No records of the ore extracted from the stope are available.

The Telegraph vein strikes on the average about $\mathbf{N}$. $65^{\circ} \mathrm{E}$. and dips $80^{\circ}-85^{\circ} \mathrm{SE}$., but about 30 feet west of the shaft on the 170 level, the vein curves to a $N$. $50^{\circ} \mathrm{I}$. strike. At the bend, branches from the vein pass into the footwall. The vein is as much as 5 feet wide and where observed consists of altered and pyritized wallrock, quartz, pyrite, and at places chalcocite; probably chalcopyrite is associated with the chalcocite. Irregular: clots and stringers of dark-gray, fine-grained quartz are associated with the chalcocite-bearing ore. At most places the vein consists of a hanging wall and footwall gouge-filled fracture, separated by as much as 5 feet of altered wallrock heavily impregnated with pyrite. The vein in the west face of the 170 level drift, 25 feet west of the shaft, was 4 feet wide and consisted of, from hanging wall to footwall : one-fourth inch of sheared sulfides and gouge; 4 feet of bleached and pyritized wallrock containing sparse subparallel quartzpyrite seams as much as 2 inches wide; and one-fourth inch of gouge.

At places massive pyrite lenses as much as 6 inches thick occur at or near the hanging wall of the vein. Southwest of the bend in the vein on the 170 level the vein consists of 1 to 2 feet of altered and pyritized wallrock, commonly containing abundant gouge and many 1- to 2-inch stringers of quartz-pyrite and chalcocite; several 1-inch-thick pyrite-filled fractures occur in the footwall. Where stoped, the vein contains lenses of chalcocite-rich vein material. A sample of coarse pyrite from the vein contained only a trace of gold and 0.16 ounce of silver per ton. ${ }^{11}$

The pitchblende found on the dump is near the shaft collar, indicating that it probably came from near the surface. Underground, pitchblende has been found about, 60 feet below the shaft collar, as tiny seams in the footwall of the vein. The occurrence seems to be too small to warlant extensive exploration.

\section{WOOD VEIN}

The Wood vein (pl. 4) has been one of the two principal sources of high-grade pitchblende ore in the Central City district, but by far the litrgest production from the mine was before 1900 (table 1). Some pitchblende ore was produced also from the Ross shaft, 580 feet east of the main Wood shaft (pl. 4).

During the current investigation the Wood vein was explored along a length of nearly 1,100 feet from the 583 level of the East Calhoun mine. This work, financed largely by the Defense Minerals Exploration

\footnotetext{
"Assay by U.S. Geological Survey. Analy'st: di. C. Mallory, Jr.
}

Administration, was followed closely by the Geological Survey and the results of these studies are given by Drake (1957). The reader is referred to Drake's report for a discussion of the geology of the Wood-East Calhoun mine.

The Wood vein strikes nearly east and dips steeply either side of vertical. It is cut and displaced by the Calhoun vein fissure 375 feet east of the Wood shaft. The vein contains sphalerite, galena, and copper minerals. Throughout its length it contains quartz and pyrite, and at places it contains small lenses of sphalerite, chalcopyrite, tetrahedrite-tennantite, galena, and pitchblende.

Pitchblende occurs as small, discontinuous lenses and streaks on the footwall of the Wood vein, which are separated by nonuraniferous rein material. Individual bodies are small and range from a few pounds to about 5 tons in weight (Bastin and Hill, 1917, p. 245). Little is known of the bodies that were mined from the upper levels of the Wood mine. Moore and Butler (1952) found 23 occurrences of pitchblende above the 275 level; their locations are shown on figure 36 ; but these occurrences undoubtedly represent only the margins of ore lenses or small streaks that were mined previously. The pitchblende bodies encountered on the 583 level were small lenses in sulfide ore on the footwall of the vein. Two lenses were found, one on the level 506 feet west of the crosscut (fig. 25) and the other in a small stope above the level. As can be seen in figure 25 , the pitchiblende-rich lens on the level was 8 feet long, about 8 feet high, and 1 to 8 inches thick; it appeared to rake about $50^{\circ} \mathrm{W}$. The richest part of the lens assayed 9.3 percent equivalent uranium and 9.94 percent uranium over a 6 -inch width, but for the most part the ore was leaner and parts of the lens were below ore grade. The photograph shown in figure 20 is of a specimen of high-grade ore taken from this lens. The lens encountered above the level in the stope was 10-15 feet long, 8-10 feet high, and a maximum of 14 inches wide; it was separated from the lower lens by barren, nonuraniferous vein material. This lens was found along the upward projection of the plunge of the lens and about 20 feet above it.

Aside from two occurrences on the 197 level east (fig. 36), all known pitchblende bodies in the Wood mine occur within a tapering westward-plunging zone of ore shoots. This shoot was first recognized by Moore and Butlei (1952, p. 6 and pl. 1). Possibly the ore mined from the Ross shaft represents the upper part of another similarly plunging shoot.

The pitchblende within the uranium-rich lenses on the 583 level is hard, black, and lustrous, and it is intimately associated with the other metallic minerals 


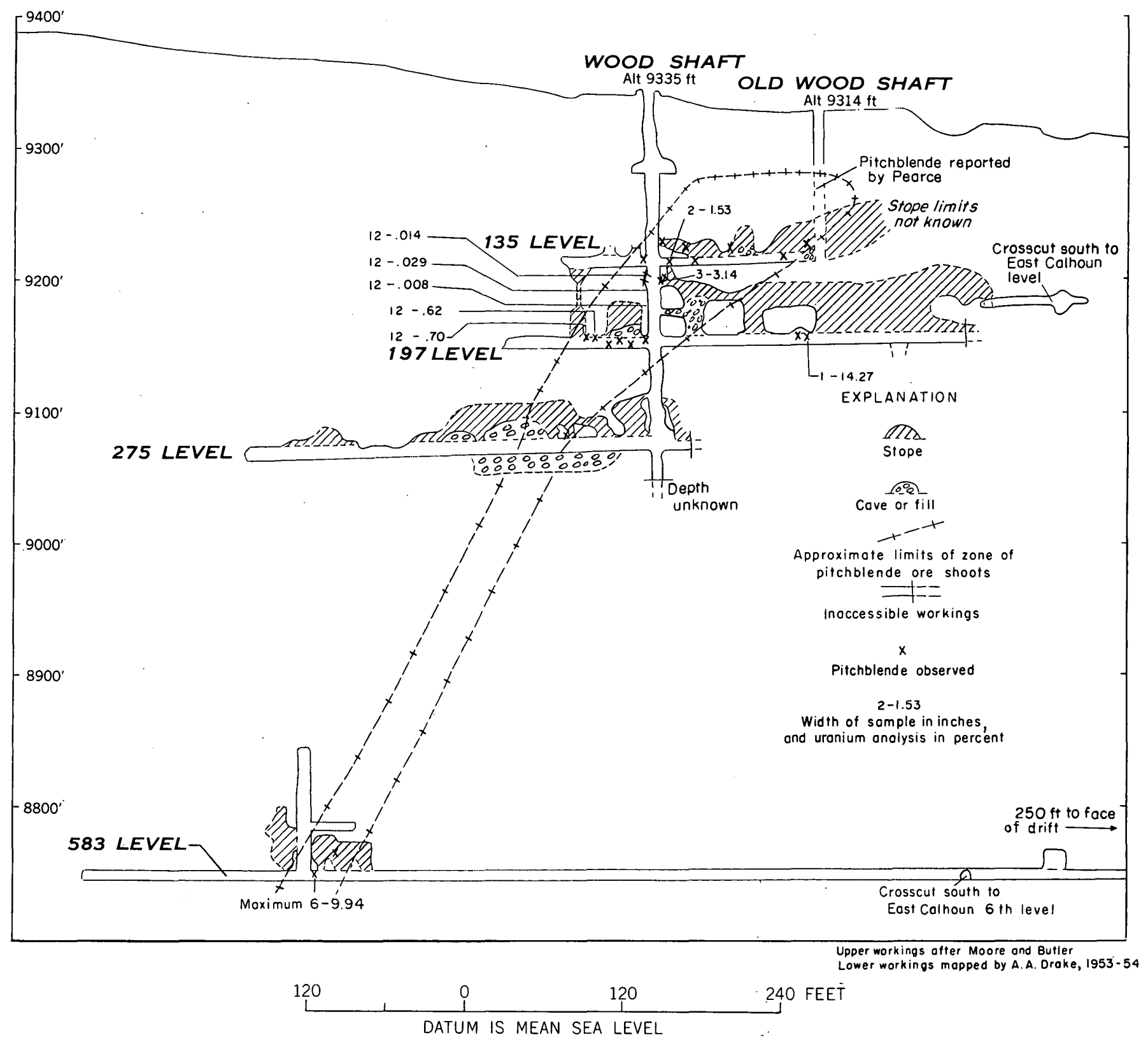

Figure 36.-Vertical longitudinal projection of the Wood mine, Central City district.

in the vein and with quartz. As shown in figure 20, the pitchblende forms pure masses commonly 1 inch or less in maximum dimension. Individual pieces are angular to subangular; they represent broken fragments of pitchblende veinlets that have been brecciated and then veined by later sulfide minerals.

Although the pitchblende appears massive megascopically, it is seen under the reflecting microscope to consist largely of tiny forms with rounded outlines which characteristically have both radial and circumferential cracks. A small amount of pale-yellow to white pyrite is intergrown with the pitchblende; most of the pyrite cuts the pitchblende and is younger. Brecciated fragments of pitchblende, which in part are rotated, are largely healed by quartz.

\section{EUREKA GULCH AREA}

The Eureka Gulch area, which includes the mines on Nigger Hill (fig. 37) and on the south side of the gulch, formerly was a source of small quantities of precious metal-bearing base-metal ores, and since the discovery of uranium in the area in 1951 it has been 
intensively explored for uranium ore. Both primary and secondary uranium deposits have been developed on Nigger Hill, and small quantities of uranium ore have been shipped, principally from the Carroll mine (table 1). The discoveries and the geologic setting of the area have been described by Sims, Osterwald, and Tooker (1955), and for a summary of the geology of this region the reader is referred to that report.

The principal uranium occurrences of the area are on Nigger Hill (fig. 37) and these deposits are described in detail in this section. Information on the deposits on the south side of Eureka Gulch is given in the report by Sims, Osterwald, and Tooker (1955).

\section{CARROLL MINE}

The Carroll mine, on the west slope of Nigger Hill, has been the principal producer of uranium ore in the Eureka Gulch area; since 1954 it has shipped 28.5 tons of crude ore and concentrates that contained 349 pounds of $\mathrm{U}_{3} \mathrm{O}_{8}$ (table 22). The production of other metals during the same period has been much greater, however, as shown in table 22.

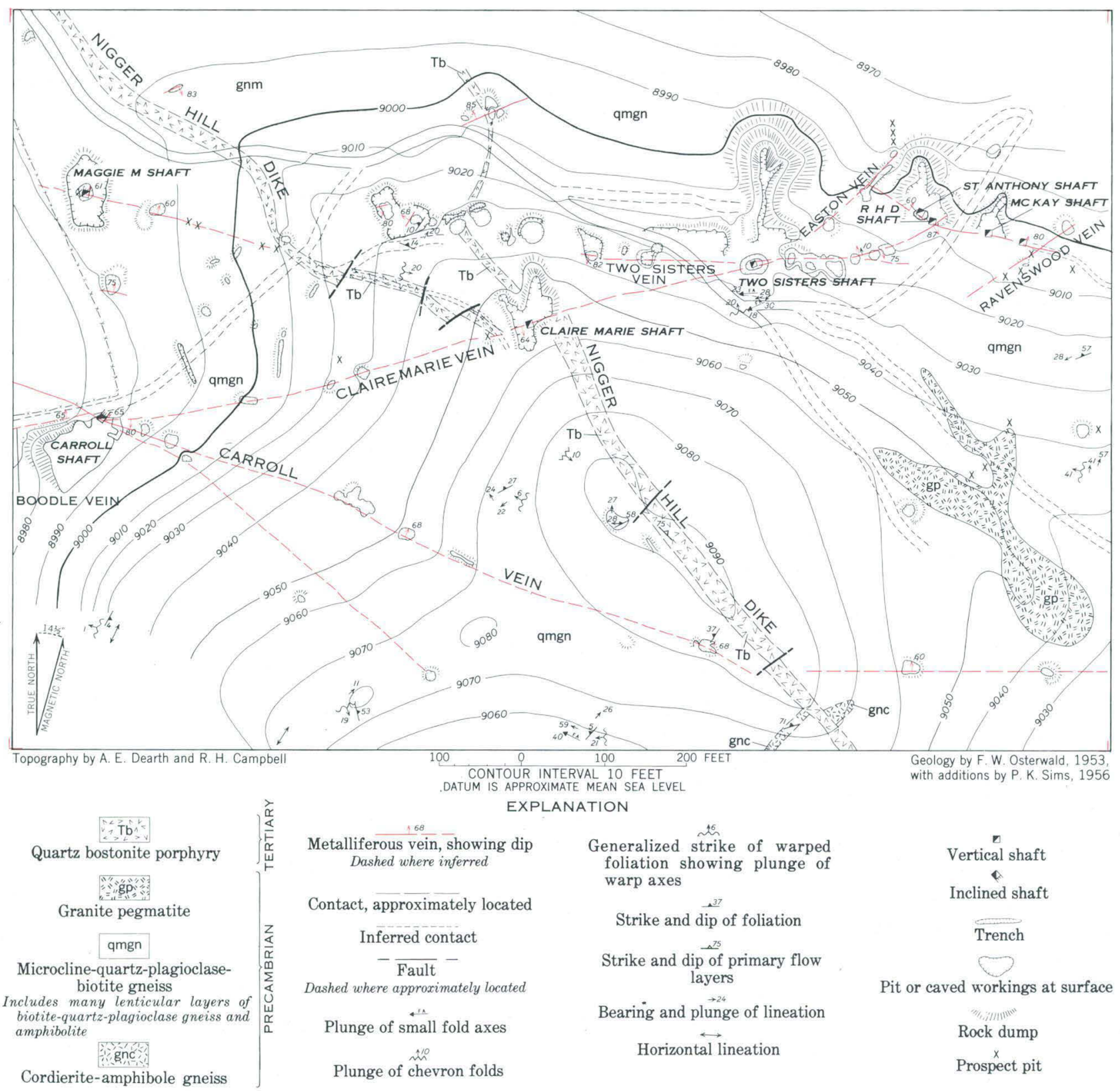

Figure 37.-Geologic map of the north slope of Nigger Hill, Central City district, Gilpin County, Colo. 
GEOLOGY OF URANIUM DEPOSITS, FRONT RANGE MINERAL BELT, COLO.

TABLE 22.-Production from the Carroll mine, 1954-551

\begin{tabular}{|c|c|c|c|c|c|c|c|c|}
\hline Year & $\begin{array}{l}\text { Crude ore } \\
\text { shipped } \\
\text { (tons) }\end{array}$ & $\begin{array}{c}\text { Concentrates } \\
\text { shipped } \\
\text { (tons) }\end{array}$ & $\begin{array}{c}\text { Gold } \\
\text { (ounces) }\end{array}$ & $\begin{array}{c}\text { Silver } \\
\text { (ounces) }\end{array}$ & $\begin{array}{l}\text { Copper } \\
\text { (pounds) }\end{array}$ & $\begin{array}{c}\text { Lead } \\
\text { (pounds) }\end{array}$ & $\underset{\text { (pounds) }}{\text { Zinc }}$ & $\begin{array}{c}\mathrm{U}_{3} \mathrm{O}_{8} \\
\text { (pounds) }\end{array}$ \\
\hline $\begin{array}{l}1954, \ldots \\
1954 \\
1954 \\
1955 \\
1955 \\
1955 \\
1955\end{array}$ & \begin{tabular}{c}
45.2 \\
12.5 \\
\hdashline-1. \\
\hdashline 4
\end{tabular} & $\begin{array}{ll}2 & 9.95 \\
2 & 27.00 \\
2 & 25.86 \\
3 & 32.91 \\
2 & 11.11\end{array}$ & $\begin{array}{r}4.52 \\
7.37 \\
14.56 \\
22.50 \\
6.09\end{array}$ & $\begin{array}{r}238.35 \\
161.76 \\
530.16 \\
571.56 \\
212.11 \\
-\end{array}$ & $\begin{array}{r}119.5 \\
362.1 \\
362.0 \\
-\cdots\end{array}$ & $\begin{array}{r}7,365 \\
4,676 \\
19,739 \\
20,121 \\
1,004 \\
-\end{array}$ & $\begin{array}{r}7,094 \\
3,704 \\
6,418 \\
6,310 \\
33,241 \\
-\end{array}$ & $\begin{array}{r}- \\
122.98 \\
\hdashline- \\
\hdashline-1 \overline{2} 5.9 \overline{8}\end{array}$ \\
\hline Total $\ldots \ldots \ldots$ & 62.57 & 106.83 & 55. 04 & $1,713.94$ & 843. 6 & 52,905 & 56,767 & 348. 96 \\
\hline
\end{tabular}

1 Data on production furnished by United Mining and Leasing Corp., and published by permission.

2 Lead concentrate.

The Carroll mine was developed largely before the turn of the century; so far as known it was idle from 1903 until 1953, when the mine was rehabilitated by the United Mining and Leasing Corp. as a result of the discovery of pitchblende on the dump (Sims, Osterwald, and Tooker, 1955). Since 1953 the old workings have been reopened, the 228 (third) level has been extended 317 feet westward, and a new level has been driven 50 feet below the third level (fig. 30). The extent of the workings is shown on figure 23 and plate 7 .

The wallrock is dominantly microcline-bearing gneiss, but the gneiss contains many thin conformable layers of biotite-quartz-plagioclase gneiss, migmatite, pegmatite, and on the 278 level, a lens of granodiorite. At places the rocks are intimately interlayered on a minute scale. Small pods and lenses of amphibolite are widely distributed in the dominant rocks. Except locally, the rocks strike northeast and dip gently to moderately northwest. Small upright drag folds are common, and small recumbent folds occur in parts of the mine.

The Carroll shaft is near the junction of four veinsthe Carroll, Boodle, Claire Marie, and an unnamed vein that trends about N. 50 $0^{\circ}$ W. (fig. 37). Only the Carroll vein, however, has been extensively developed and mined, and aside from a few tons of ore from the Boodle vein, all the production from the mine has come from the Carroll vein. The veins are of galena-sphalerite. The dominant sulfide minerals are sphalerite and galena; pyrite, chalcopyrite, and tennantite are sparse, and pitchblende and its alteration products occur in the Carroll vein and locally in the Claire Marie vein. Quartz is the principal gangue mineral in all veins, but nowhere is it abundant.

The northwestward-trending unnamed vein has been prospected southeast of the shaft and was explored in the mine in the stub drift at a vertical depth of 52 feet (fig. 23); this vein joins with the Carroll vein in the shaft at a depth of 73 feet (pl. 7).

The Claire Marie(?) vein was intersected in the sublevel above the 102 level (pl. 7) ; it joins with the Carroll vein in the raise between the sublevel and the 102 level. The vein strikes about N. $80^{\circ}$ E. and dips about $80^{\circ} \mathrm{S}$. in the sublevel, but it curves into the Carroll vein and reverses dip at the junction. Except for a small lens of galena-rich ore, the vein is nearly barren where exposed. Near the face of the sublevel, a footwall stringer contains a secondary uranium mineral tentatively identified as kasolite, and locally abundant gold and silver (see analyses $\mathrm{C}-1$ and $\mathrm{C}-1 \mathrm{~A}$, table 26 ).

The Boodle vein joins with the Carroll vein 145 feet west of the shaft on the 228 level and slightly farther west of the shaft on the 278 level (pl. 7); the junction plunges about $50^{\circ} \mathrm{NW}$. In the mine, the Boodle vein strikes about N. $80^{\circ} \mathrm{E}$. and dips about $65^{\circ} \mathrm{N}$. Near the junction with the Carroll vein, the vein is as much as 2 feet thick, and it contains sphalerite as the dominant sulfide mineral and sparse galena.

The Carroll vein strikes about $\mathrm{N} .70^{\circ} \mathrm{W}$. and dips $65^{\circ}$ NE., but locally it varies a few degrees in both strike and dip (pl. 7). It is commonly 2 to 4 feet wide, but where mined on the 228 and 278 levels it is commonly 4-6 wide and locally as much as 9 feet wide. At most places the vein consists of two or more principal subparallel vein fissures that are separated by fractured, brecciated, and altered wallrock which is mineralized to different degrees. In the ore shoot on the 228 and 278 levels, a well-developed vein fissure forms the footwall, and one or more similar fissures form the hanging wall of the vein. The intervening country rock is cut by a network of interlacing fractures and commonly is brecciated. Both the breccia and the fractures are mineralized. The brecciated ore consists of subangular to 
angular fragments of altered wallrock that are coated by sulfide minerals and locally quartz, the whole constituting ore. Vugs between the breccia fragments and in the fractures commonly contain terminated quartz crystals and locally galena crystals as much as 1 inch in diameter. At most other places in the mine the vein consists of one or more distinct vein fissures, commonly only " few inches in maximum width, that contain gouge and sulfide minerals.

The uranium ore in the Carroll vein occurs within a zone of ore shoots that plunges about $35^{\circ} \mathrm{NW}$. The approximate outline of the shoot is shown on figure 23 . The zone of ore shoots has an average width of about 60 feet and a known plunge length of more than 300 feet. It coincides with a large shoot of base-metal ore that, has been mined on the 177 and 228 levels and which has been developed on the 278 level (compare fig. 23 and pl. 7). The zone of uranium ore shoots, as well as the base-metal ore shoot, occurs at, and southeast of the junction of the Boodle vein and the Carroll vein. On the 228 and 278 levels, minable base-metal ore extends more than 100 feet southeast from the junction. As described previously in this report (p. 42 ; and fig. 23 ), the zone of ore shoots plunges nearly parallel ito the trace of the intersection of the Carroll vein fissure and the lithologic layering of the Precambrian wallrocks. The factors responsible for the localization of the ore are discussed on page 47 .

Because of the occurrence of economically important deposits of pitchblende and the uncommonly good opportunity to study the vein during active mining, the Carroll vein was mapped in detail and many samples were taken to determine the distribution and quantitative variations of gold, silver, copper, lead, zinc, and uranium (tables 23 and 24; fig. 38). Although the lower (278) level was mapped, it was not sampled.

The ore in the base-metal sulfide ore shoot is chiefly valuable for its lead, zinc, and silver content; gold is sparse and rarely exceeds 0.04 ounce per ton. The copper content of the ore is negligible. Uranium ore locally is closely associated with the base-metal sulfides; it is described separately later. As can be seen in tables 23 and 24, the Carroll vein is low in grade except in the ore shoot, commonly containing less than 3 percent combined lead and zinc and less than 3 ounces of silver per ton. Within the shoot, however, the base-metal and silver content is increased several fold. The base-metal ore mined from the 228 level on the average contained about 15 percent combined lead and zinc, 0.01 to 0.1 ounce of gold per ton, 5 ounces of silver per ton, and 0.5 percent copper. Lead was nearly as abundant as zinc on the 228 level. On the 278 level, however, the lead content of the shoot probably averages only about 5 per- cent, whereas zinc averages more than 10 percent. Silver increases substantially with an increase in lead and zinc. (See analyses from the 228 level, table 23.).

Although primary uranium ore occurs in the same part of the vein as the base-metal ore, it is much less abundant. The pitchblende-bearing ore forms several small ore shoots that are arranged en echelon within the zone of ore shoots outlined on figure 23. The vein between the separate ore shoots is nearly devoid of uranium as shown on plate 7 and tables 23 and 24. The largest known shoot, on the 228 level west, has a height of about 50 feet, a stope length of as much as 50 feet, and an average thickness of about 6 inches. A smaller shoot, with a maximum horizontal length of only about 11 feet and a thickness of less than 6 inches, was mined east of the shaft on the 177 level. Other, probably still smaller shoots, were partly mined farther east along the vein, in the stope between the 102 and 177 levels (fig. 23). The grade of the ore within the shoots, as determined by samples taken during this investigation, is given in tables 23 and 24 and in figure 38 . For details of the occurrence of pitchblende within the shoots, the reader is referred to page 44 .

In the upper part of the mine, the pitchblende was altered by supergene solutions and there is a complete gradation from the primary ore mineral to secondary minerals. The pitchblende was changed to a soft sooty variety at and above the 177 level and was altered to brightly colored secondary uranium minerals down to the 102 level. As a result of the alteration, uranium was somewhat dispersed along the vein in the upper part of the mine and accordingly the tenor of the material containing secondary uranium minerals is lower than the primary ore. (See pl. 7 and fig. 38.) Some pitchblende in the stope above the 177 level was leached by both supergene water and water that collected after development of the mine. As a result the equivalent uranium content of the material now is greatly in excess of the uranium content. (See analyses C-1-8A and $\mathrm{C}-1-10$, table 23.)

Spectrographic analyses of the ores (table 23) indicate that the uranium-bearing ores are characterized by a somewhat different suite of trace elements than the base-metal ores. There is a direct correlation of antimony, tungsten, molybdenum, zirconium, yttrium, and ytterbium with uranium, but unusually large quantities of these elements do not occur in all analyzed samples. It was shown in an earlier section that the pitchblende from the Carroll mine (table 13) contains unusually large quantities of molybdenum, tungsten, yttrium, and zirconium. Zirconium and yttrium, and at places tungsten and molybdenum, are characteristically associated with pitchblende. The antimony in the uranium ores 
TABLE 23.-Chemical analyses, fire assays, and semiquantitative

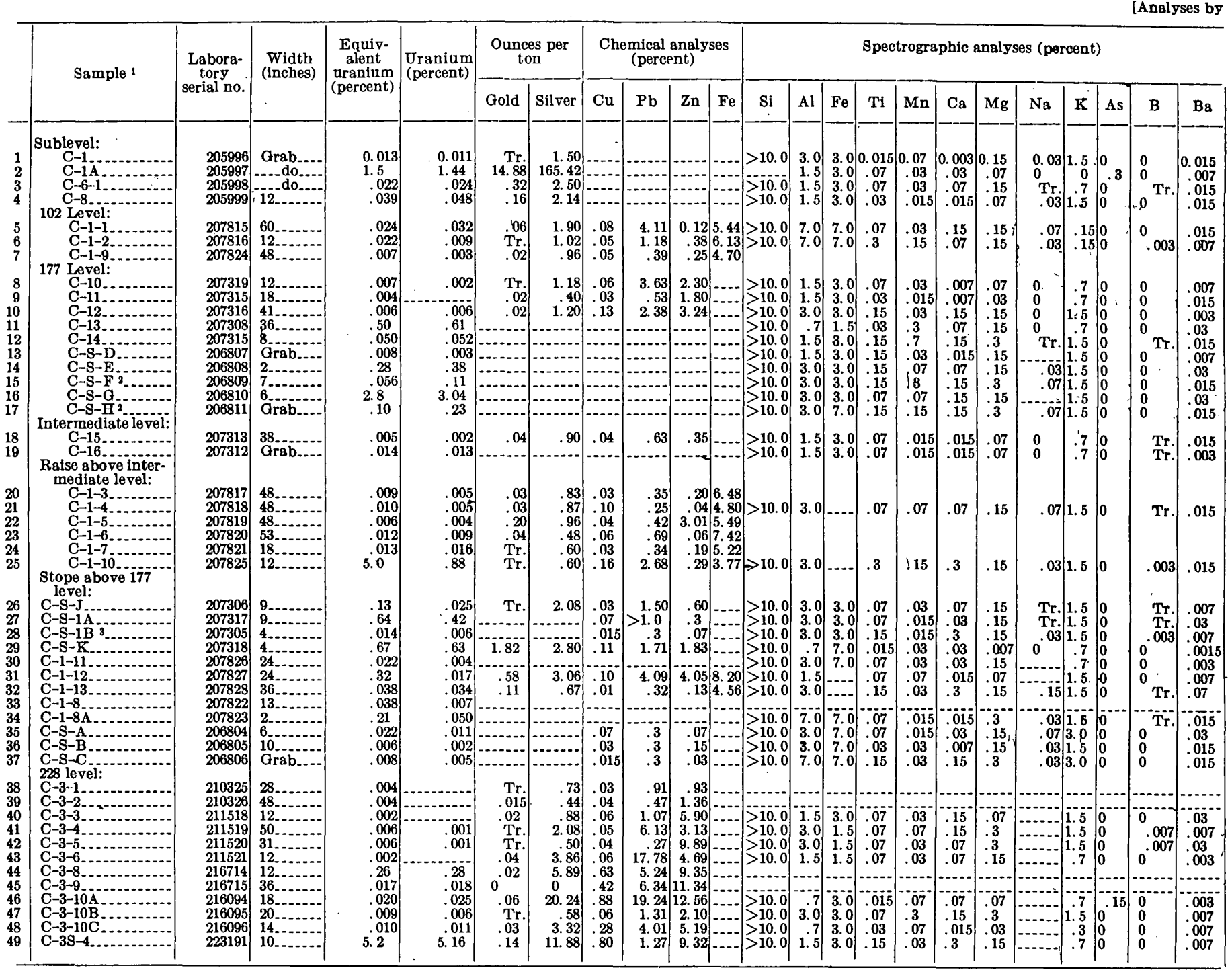

1 Location of samples shown on figure 38. Gouge on footwall of vein.

3 Contains trace of $\mathrm{P}$. Looked for but not found: P, Ce, Dy, Er, Gd, Hf, Hg, Ir, Li, Nd, Os, Pd, Pt,
Re, Rh, Ru, Sm, Ta, Th, and Te.

Analysts: D. L. Skinner, E. C. Mallory, Jr., J. P. Schuch, R. G. Havens,
N. M. Conklin, G. W. Boyes, S. P. Furman, H. E. Bivens, R. F. Dufour, R Tr. means trace (chemical analyses) and thréshold dmount (spectrographic analyses).

0 means looked for but not foun 
spectrographic analyses of vein material from the Carroll mine

U.8. Gool. Survey]

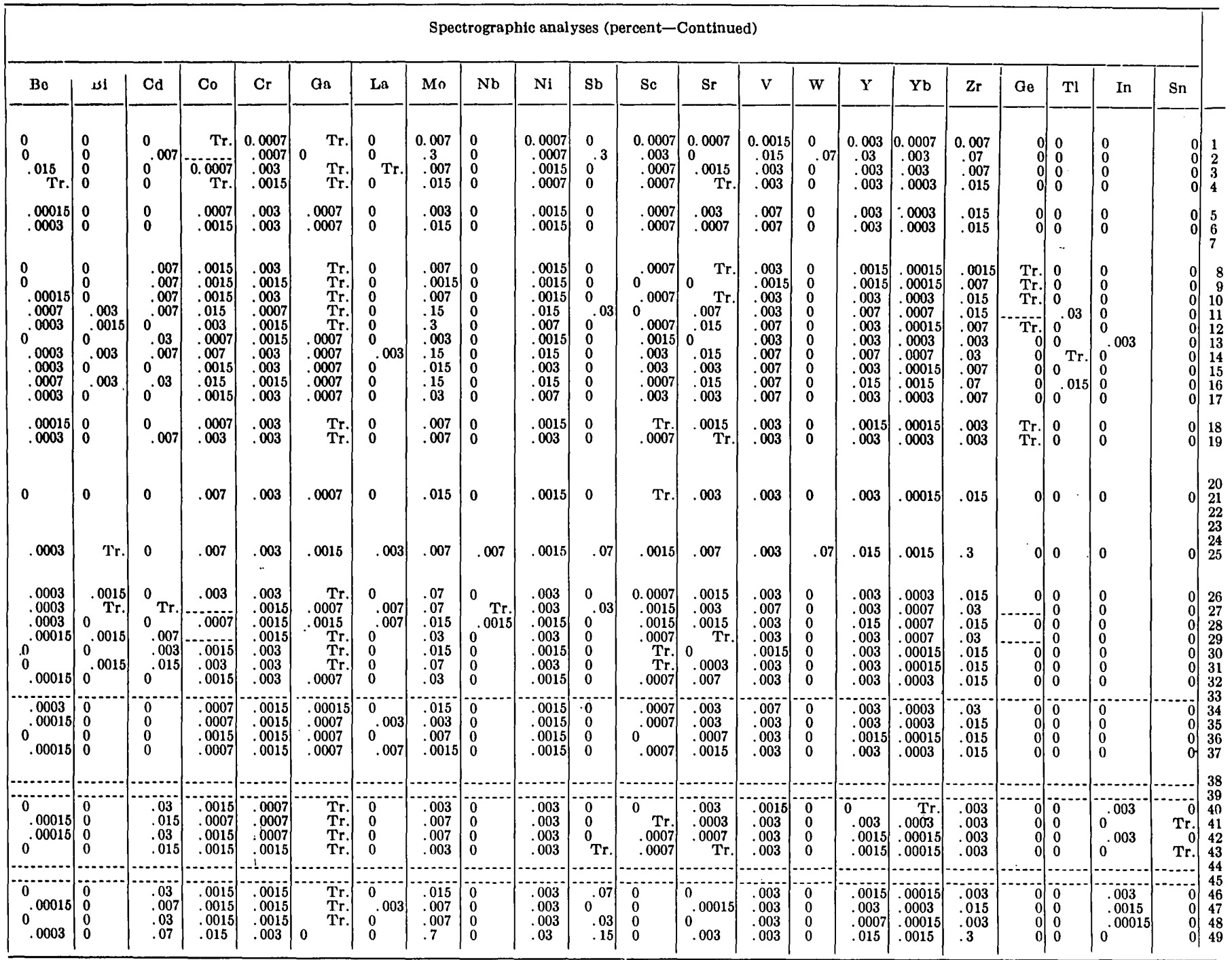




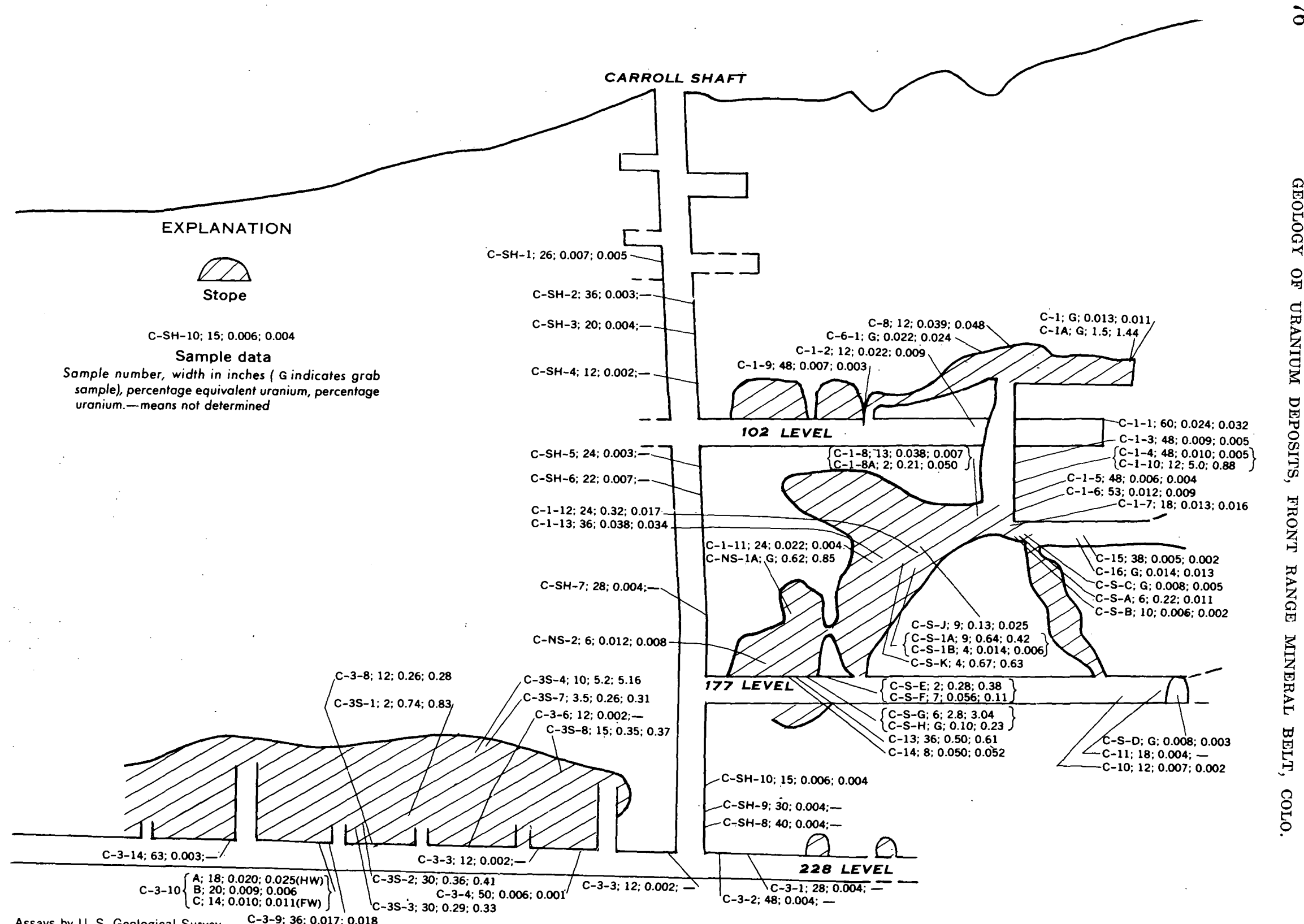

Assays by U. S. Geological Survey C-3-9; 36; 0.017; 0.018

$$
0.40 \quad 80 \quad 120 \text { FEET }
$$

Figure 38.-Assay section, Carroll mine. Additional sample data given in tables 23 and 24 
TABLE 24.-Chemical analyses and fire assays of vein material from shaft and stopes of the Carroll mine [Analyses by U.S. Geol. Survey]

\begin{tabular}{|c|c|c|c|c|c|c|c|c|c|c|}
\hline \multirow{2}{*}{ Sample 1} & \multirow{2}{*}{$\begin{array}{c}\text { Laboratory } \\
\text { serial No. }\end{array}$} & \multirow{2}{*}{$\begin{array}{c}\text { Width } \\
\text { (inches) }\end{array}$} & \multirow{2}{*}{$\underset{\substack{\text { Equivalent } \\
\text { (percent) }}}{\mid}$} & \multirow{2}{*}{$\begin{array}{l}\text { Uranium } \\
\text { (percent) }\end{array}$} & \multicolumn{2}{|c|}{ Ounces per ton } & \multirow{2}{*}{$\begin{array}{l}\text { Copper } \\
\text { (percent) }\end{array}$} & \multirow{2}{*}{$\begin{array}{c}\text { Lead } \\
\text { (percent) }\end{array}$} & \multirow{2}{*}{$\begin{array}{c}\text { Zinc } \\
\text { (percent) }\end{array}$} & \multirow{2}{*}{$\begin{array}{c}\text { Iron } \\
\text { (percent) }\end{array}$} \\
\hline & & & & & Gold & Silver & & & & \\
\hline 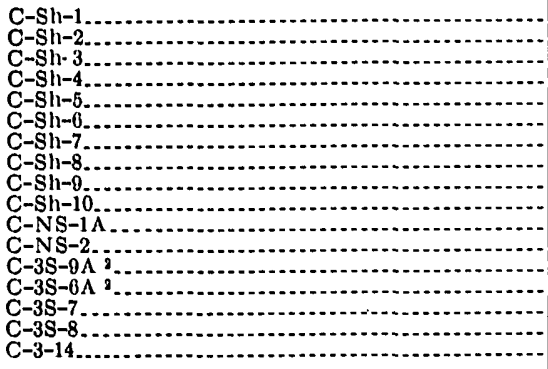 & $\begin{array}{l}210313 \\
210314 \\
210315 \\
210316 \\
210317 \\
210318 \\
210319 \\
210320 \\
210321 \\
210322 \\
210323 \\
210324 \\
225613 \\
224973 \\
224974 \\
224975 \\
224976\end{array}$ & 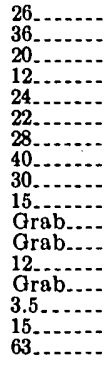 & $\begin{array}{l}0.007 \\
.003 \\
.004 \\
.002 \\
.003 \\
.007 \\
.004 \\
.004 \\
.004 \\
.006 \\
.62 \\
.012 \\
.001 \\
.003 \\
.26 \\
.35 \\
.003\end{array}$ & $\begin{array}{l}0.005 \\
\text { n.d. } \\
\text { n.d. } \\
\text { n.d. } \\
\text { n.d. } \\
\text { n.d. } \\
\text { n.d. } \\
\text { n.d. } \\
\text { n.d. } \\
.004 \\
.85 \\
.008 \\
\text { n.d. } \\
\text { n.d. } \\
.31 \\
.37 \\
\text { n.d. }\end{array}$ & $\begin{array}{c}0.06 \\
.01 \\
.06 \\
\mathrm{Tr} . \\
.08 \\
\mathrm{Tr} . \\
\mathrm{Tr} . \\
\mathrm{Tr} . \\
.08 \\
\mathrm{Tr} . \\
\mathrm{Tr} . \\
\mathrm{Tr} . \\
.04 \\
.08 \\
.10 \\
2.54 \\
.22\end{array}$ & $\begin{array}{r}0.56 \\
.39 \\
.60 \\
.51 \\
1.28 \\
.18 \\
.16 \\
.86 \\
1.48 \\
.60 \\
.98 \\
.58 \\
8.42 \\
2.20 \\
4.00 \\
5.10 \\
3.12\end{array}$ & $\begin{array}{l}0.06 \\
.06 \\
.11 \\
.01 \\
.04 \\
.01 \\
.01 \\
.06 \\
.06 \\
.01 \\
.05 \\
.01 \\
.33 \\
.18 \\
.48 \\
.23 \\
.21\end{array}$ & $\begin{array}{r}0.94 \\
.27 \\
.54 \\
.29 \\
3.14 \\
.67 \\
.10 \\
.95 \\
2.70 \\
.05 \\
2.01 \\
.27 \\
9.28 \\
5.95 \\
7.97 \\
5.76 \\
10.38\end{array}$ & $\begin{array}{r}0.04 \\
.04 \\
.10 \\
.11 \\
1.22 \\
.06 \\
.08 \\
.10 \\
6.35 \\
.04 \\
.97 \\
.40 \\
10.28 \\
10.32 \\
7.98 \\
8.51 \\
9.13\end{array}$ & $\begin{array}{l}\text { n.d. } \\
\text { n.d. } \\
\text { n.d. } \\
\text { n.d. } \\
\text { n.d. } \\
\text { n.d. } \\
\text { n.d. } \\
\text { n.d. } \\
\text { n.d. } \\
\text { n.d. } \\
\text { n.d. } \\
\text { n.d. } \\
4.61 \\
4.73 \\
5.01 \\
\text {. } 96 \\
\text { 5.01 }\end{array}$ \\
\hline
\end{tabular}

could be due to inclusions of tetrahedrite-tennantite, but judging from the copper analyses this mineral is too sparse to account for the antimony.

\section{CLAIRE MARIE MINE}

The Claire Marie mine is 280 feet southwest of the 'Two Sisters shaft and 520 feet northeast of the Carroll shaft (fig. 37). In 1953 small quantities of secondary uranium-bearing material were found on the mine dump (Sims, Osterwald, and Tooker, 1955), and in 1954 the mine was reopened and rehabilitated by the Central City Uranium Co. As a result of the reopening, small lenses of pitchblende and rich lead ore were found on the 206 level, west of the shaft.

The Claire Marie mine workings consist of a shaft more than 216 feet deep, which is inclined steeply southeast (fig. 39), and 2 levels at vertical depths of 124 and 206 feet. Fxtensive stoping was done east of the shaft (fig. 42).

The vein intersects Precambrian microcline-bearing gneiss, granite pegmatite, and amphibolite and Tertiary quartz bostonite porphyry. Except locally the Precambrian - wallrocks strike northeast and dip gently northwest (fig. 39). The quartz bostonite porphyry seems to occur in small lenses rather than as a continuous body; possibly it is sheared, broken, and offset in the vein zone. The quartz bostonite porphyry is several times as radioactive as the Precambrian wallrocks and at many places is more radioactive than the vein.

The Claire Marie vein strikes N. $70^{\circ}-90^{\circ}$ E. and, except locally, dips steeply southeast. West of the shaft on both levels the vein strikes $\mathrm{N} .70^{\circ}-80^{\circ} \mathrm{E}$, but east of the shafti on the 124 level it strikes more easterly. In the stoped ground east of the shaft the vein dips nearly vertically. Typically, the vein is 1 to 6 inches thick and consists of gouge and sparse quartz and pyrite; at places it contains abundant galena and sphalerite and lesser amounts of pitchblende. On the 206 level, near the west face, the vein is as much as 18 inches wide and consists of several subparallel veinlets of galena, sphalerite, and pitchblende as much as 3 inches wide that are separated by altered wallrock. The pitchblende at this location is in separate fractures, subparallel and locally adjacent to the galena-sphalerite-bearing fissures. The base-metal mineral-filled fissures characteristically have a quarter of an inch to half an inch of sphalerite adjacent to the walls and 1 inch or more of coarse cubic galena in the center. Analyses from the 206 level west (fig. 42) are given below :

Analyses from the 206 level west, Claire Marie mine

\begin{tabular}{|c|c|c|c|c|c|c|}
\hline \multirow{2}{*}{ Sample location } & \multirow{2}{*}{$\begin{array}{l}\text { Width } \\
\text { (feet) }\end{array}$} & \multicolumn{2}{|c|}{ Ounces per ton } & \multirow{2}{*}{$\begin{array}{c}\text { Lead } \\
\text { (percent) }\end{array}$} & \multirow{2}{*}{$\underset{\text { (percent) }}{\operatorname{Zinc}}$} & \multirow{2}{*}{$\begin{array}{c}\mathrm{U}_{3} \mathrm{O}_{3} \\
\text { (percent) }\end{array}$} \\
\hline & & Gold & Silver & & & \\
\hline $\begin{array}{l}12 \mathrm{ft} \text { southwest of } \\
\text { shaft......... } \\
\text { Face } 1\end{array}$ & \multirow{2}{*}{$\begin{array}{l}0.25 \\
.4 \\
.03\end{array}$} & \multirow{2}{*}{$\begin{array}{r}0.18 \\
.22 \\
.03\end{array}$} & \multirow{2}{*}{$\begin{array}{c}0.52 \\
17.3 \\
101.3\end{array}$} & \multirow{2}{*}{$\begin{array}{l}6.9 \\
9.5 \\
9.1\end{array}$} & \multirow{2}{*}{$\begin{array}{r}11.3 \\
16.3 \\
8.9\end{array}$} & \multirow{2}{*}{$\begin{array}{l}0.18 \\
.09 \\
1.15\end{array}$} \\
\hline Do.2 & & & & & & \\
\hline
\end{tabular}

1 Sulfide streak from footwall of vein.

2 Mixed sulfide minerals and gouge from hanging wall of vein.

Assays of crude ore and concentrates shipped from the mine to the Idaho Springs sampling works in 1923 and 1924 are given below:

Sampling-lcorls assays of ore from the Claire Marie mine. $192.9-24^{1}$

[Analyses by Idaho Springs sampling works]

\begin{tabular}{|c|c|c|c|c|c|}
\hline \multirow{2}{*}{ Year } & \multirow{2}{*}{ Tons } & \multicolumn{2}{|c|}{ Ounces per ton } & \multirow{2}{*}{$\begin{array}{c}\text { Lead } \\
\text { (percent) }\end{array}$} & \multirow{2}{*}{$\underset{\text { (percent) }}{\operatorname{Zinc}}$} \\
\hline & & Gold & Silver & & \\
\hline $1923 \ldots$ & $\begin{array}{r}23.09 \\
32.46 \\
3.93\end{array}$ & $\begin{array}{r}0.97 \\
.24 \\
1.79\end{array}$ & $\begin{array}{l}13.50 \\
12.00 \\
15.65\end{array}$ & $\begin{array}{l}34.50 \\
35.03 \\
18.38\end{array}$ & $\begin{array}{r}11.08 \\
5.00 \\
13.50\end{array}$ \\
\hline
\end{tabular}

1 Published by permission of W. Price Briscoe. Concentrates. 

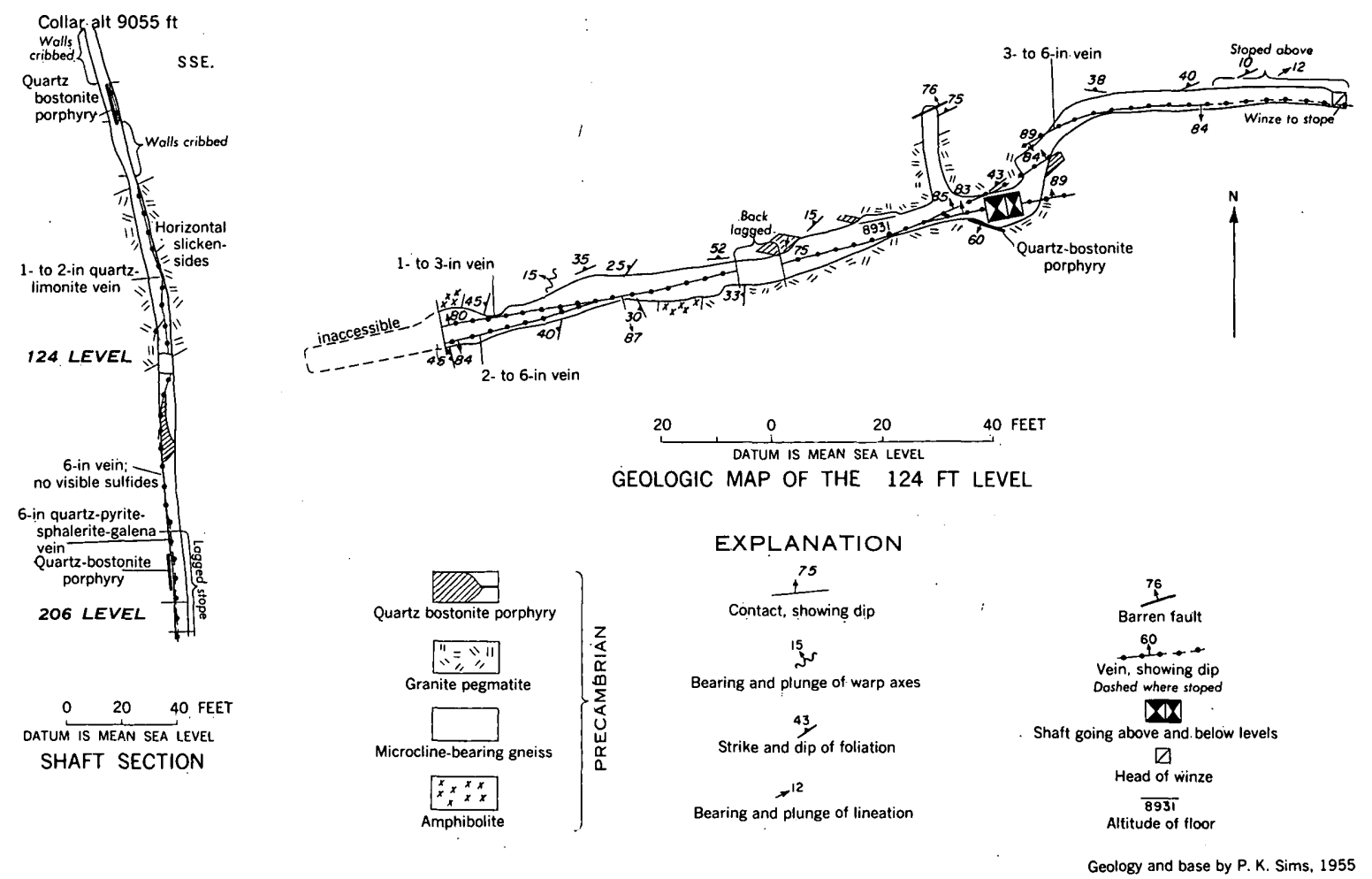

Figure 39.-Geologic map and section of the Claire Marie mine, Central City district.

ST. ANTHONY AND R.H.D. MINES

The St. Anthony and R.H.D. mines are on the north slope of Nigger Hill (fig. 37). As the workings of the two mines are connected, they are discussed together in this report.

The St. Anthony mine workings consist of a shaft, reportedly about 230 feet deep (C. R. McKay, oral communication), which is inclined an average of $88^{\circ}$ SW., and a drift at a vertical depth of 103 feet (fig. 40). The drift develops the R.H.D. vein and the Easton vein.

The R.H.D. mine workings consist of the R.H.D. shaft, the McKay shaft, and connecting drifts (fig. 40). The R.H.D. shaft is 91 feet deep. It is vertical to a depth of 61 feet and inclined steeply south below that depth. The lower inclined part of the shaft is offset 6 feet east of the upper, vertical part. A short level at a vertical depth of 53 feet connects to the east through a small stope, now caved, with the 42 level of the McKay shaft. The bottom (91) level of the R.H.D. shaft connects to the St. Anthony drift, as shown on figure 40.

The wallrocks in the two mines are principally Precambrian michocline-bearing gneiss and granite pegmatite. A few small pods of amphibolite were observed on the 53 level of the R.H.D. mine." Both amphibolite and biotite-quartz-plagioclase gneiss are much less abundant than in the McKay shaft workings (Sims, Osterwald, and Tooker, 1955, p. 24-26, fig. 2). For the most part the Precambrian rocks strike northeast and dip gently northwest, but there are local departures from this general attitude.

Four veins have been intersected in the mine workings: the R.H.D., Easton, Claire Marie (?), and Ravenswood. 'The R.H.D. vein, the principal vein developed in each of the mines, trends west-northwest and dips steeply either side of $90^{\circ}$. In the 103 level of the St. Anthony mine the vein strikes N. $60^{\circ} \mathrm{W}$., but at other places it strikes more westerly. The vein consists of one or more subparallel vein fissures, and splits and branches are common, particularly in the McKay shaft workings.

The Easton vein, so named because it is within and parallel to the boundaries of the Easton claim, strikes N. $60^{\circ}$ E. and dips $80^{\circ} \mathrm{NW}$. to $90^{\circ}$. It intersects and apparently offsets the R.H.D. vein, 40 feet northwest of the St. Anthony shaft. The vein is narrow, commonly only 1 to 4 inches thick but it contains as much as 3 inches of massive sulfides.

A nearly vertical, northeastward-trending vein fissure, probably a continuation of the Claire Marie vein, cuts and. offsets the R.H.D. vein a short distance east of the R.H.D. shaft on the 103 level (fig. 40). The apparent horizontal displacement of the R.H.D. vein 
at the 53 level, R.I.D. shaft, is about 15 inches (fig. 40 ), the northwest side having moved northeast (relative to the southenst side. Nearly horizontal slickensides are abundant along the vein.

On the 42 level of the McKay shaft workings, 75 feet east of the McKay shaft, a northeastward-striking vein, probably the Ravenswood, intersects the R.H.D. vein. For a description of this vein, the reader is referred to the report by Sims, Osterwald, and Tooker (1.955, fig. 2).

Each of the veins is similar in general appearance and mineralogy. They consist largely of gouge and breccia and contain minor amounts of quartz and sparse sulfides. All the veins, where exposed, are partly oxidized, and they contain abundant hydrous iron oxides. Galen and sphalerite, partly altered to secondary minerals, were observed only on the Easton vein. The alteration of the wallrocks in the McKily workings, which is typical of the alteration in the oxidized parts of all the veins, has been described previously (Sims, Osterwald, and Tooker, 1955; p. 15-17).

All the veins are abnormally radioactive, but material of ore grade is sparse. Assays from the R.H.D. vein in the McKay shaft workings (Sims, Osterwald, and Tooker, 1955, fig. 2 and table 2) show as much as 0.19 percent uranium; an assay from the Ravenswood vein, near the east face of the level, gave 0.14 percent uranium. On the 103 level of the St. Anthony mine, the radioactivity of the R.H.D. vein east of the shaft is 2 to 8 times the background count, but west of the shaft it is about equal to the background count (fig. 40). Sample SA-1 assayed 0.058 percent equivalent uranium and 0.072 percent uranium. Two small areas of abnormal radioactivity are present on the Easton vein (fig. 40). A radioactive area, about 4 feet long, occurs at the northeast end of the small stope, 30 feet southwest of the bend in the drift. A 2 -inch chip sample (SA-2) of the most radioactive part of the vein assayed 0.11 percent equivalent uranium and 0.14 percent uranium. Another small area of radioactivity, 4 feet long, is present at and hear the intersection of a small veinlet with the Easton vein, 50 feet southwest of the bend in the drift (fig. 40). The highest analysis (SA-4) indicated 0.10 percent equivalent uranium and 0.11 percent uranium. The Claire Marie(?) vein apparently is barren where cut at the bottom of the
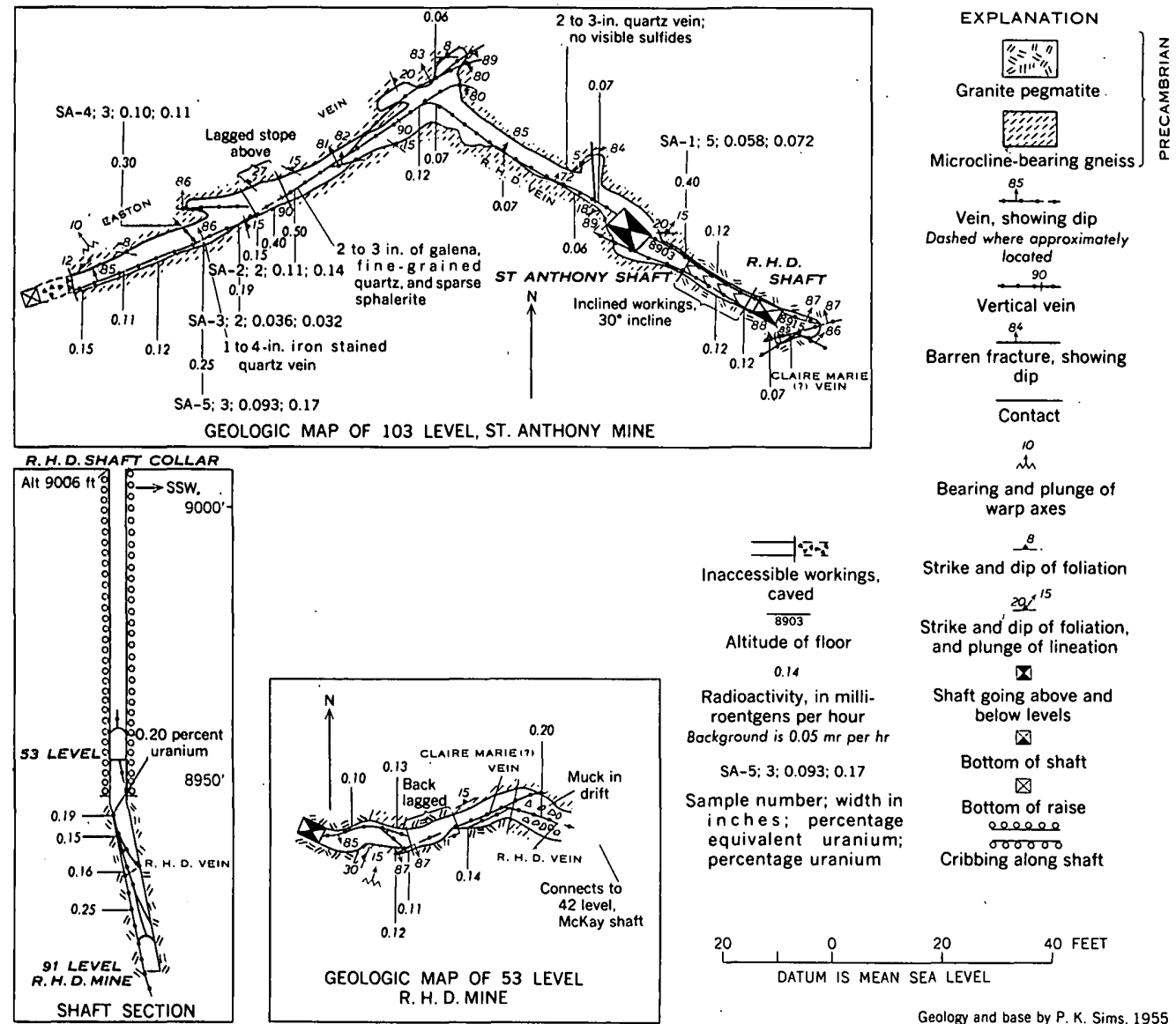

Figure 40.-Geologic maps and section, St. Anthony and R.H.D. mines, Central City district. 


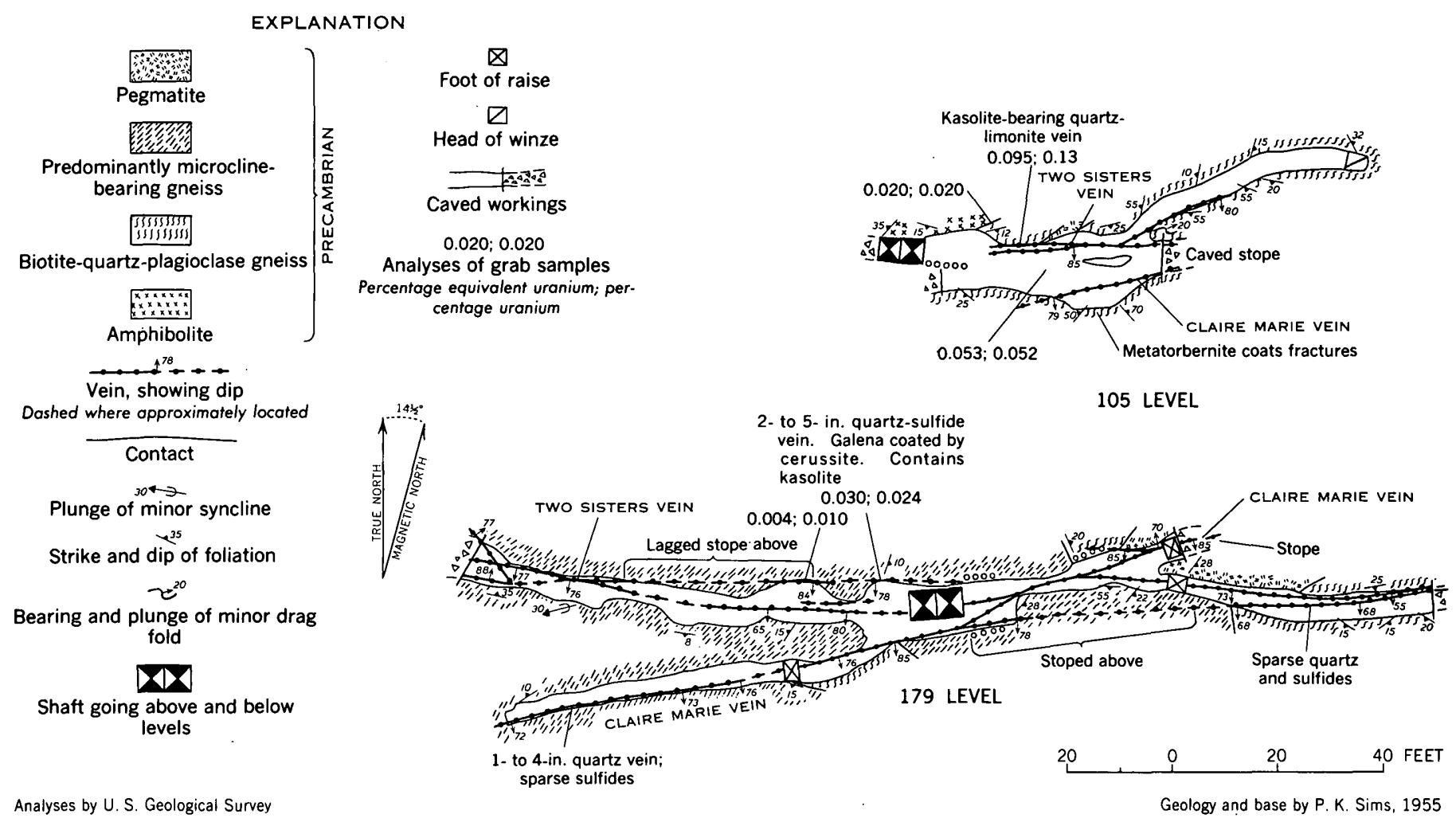

Figure 41.-Geologic maps of the 105 and 179 levels, Two Sisters mine, Central City district.

R.H.D. shaft, but it is 2 to 3 times the background count in the 53 level.

The source of the radioactivity in the veins is probably largely kasolite, but this mineral has not been positively identified from the St. Anthony and R.H.D. mines.

The widespread but low radioactivity of the veins probably resulted from dispersal of uranium in the oxidized parts of the veins, similar to the disposal noted in the Carroll vein. During oxidation of the primary vein the uranium migrated a small distance outward from the primary bodies, and accordingly the grade of the secondary material is lower than that of the primary material. During oxidation, metatorbernite replaced favorable wallrocks adjacent to the radioactive veins, as described previously from the McKay shaft workings (Sims, Osterwald, and Tooker, 1955, p. 17-18).

\section{TWO SISTERS MINE}

The Two Sisters mine is on the north slope of Nigger Hill, east-northeast of the Carroll mine (fig. 37). The mine was opened and worked primarily before the turn of the century. It was reopened and rehabilitated in 1955 to determine the economic potential of the uranium occurrences in the mine, indicated by the presence of secondary uranium minerals on the dump (Sims, Osterwald, and Tooker, 1955, p. 27). In 1954, 510 pounds of metatorbernite-bearing ore that assayed 1.80 percent $\mathrm{U}_{3} \mathrm{O}_{8}$ was shipped from the dump. ${ }^{12}$

The Two Sisters mine workings consist of a shaft, which according to a private company report by Daniel Munday is 700 feet deep, and 3 levels at vertical depths of 105, 179, and 320 feet (fig. 42). Most of the stopes are on the upper levels.

The wallrock is mainly Precambrian microcline-bearing gneiss; but several layers of biotite-quartz-plagioclase gneiss, pegmatite, amphibolite, and sillimanitic biotite-quartz gneiss are present in the mine (fig. 41). At places the different rock units are intimately interlayered. On the average the rocks trend northeast and dip gently either north west or southeast. .Judging from the data obtained on the 105 and 179 levels the rocks are folded into small open anticlines and synclines that plunge gently to the southwest.

Two veins, the Two Sisters and the Claire Marie, which intersect east of the shaft (fig. 37), have been developed in the mine (fig. 41). Each vein has been mined locally (figs. 42 and 43). As shown in figure 42, the Two Sisters and Claire Marie mines are connected through a stope on the Claire Marie vein.

The Two Sisters vein strikes nearly east and dips about $80^{\circ} \mathrm{S}$. It consists of one or more 1-inch-thick

12 Data on production furnished by United Mining and Leasing Corl., and published by permission. 


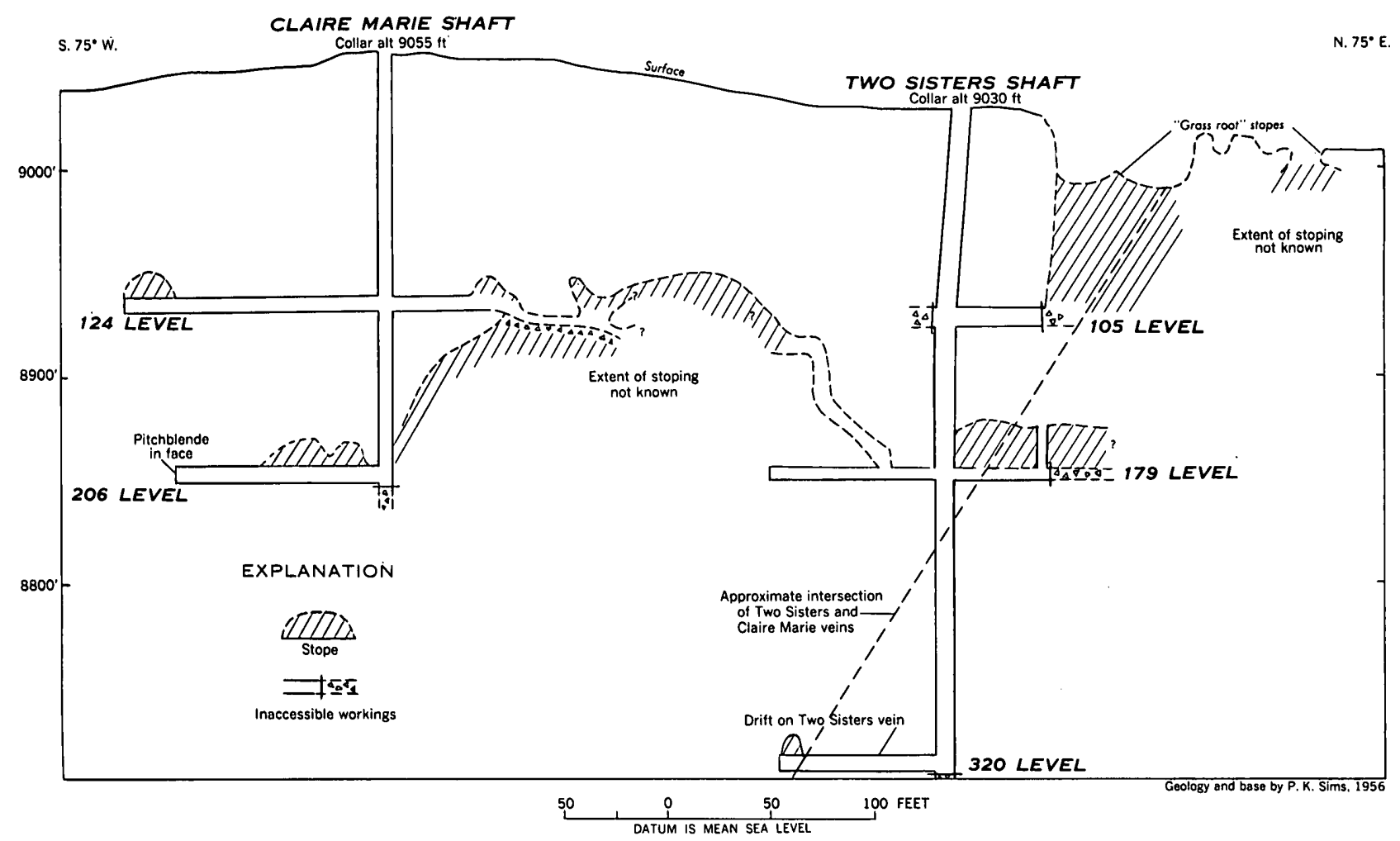

Figure 42.-Vertical longitudinal projection showing workings on Claire Marie veln, Nigger Hill.

vein fissures that contain gouge, sparse quartz, and local sulfide minerals, principally galena and sphalerite. Pyrite is sparse. The secondary uranium mineral kasolite occurs at places and metatorbernite fills fissures or is disseminated through wallrock. Locally the separate vein fissures are as much as 6 inches thick and contain galena as the dominant sulfide mineral and lesser amounts of sphalerite. At the junction of a footwall and a hanging-wall split on the 179 level west, the vein is as much as 12 inches wide and consists of several parallel 1-inch-thick stringers of sulfide minerals.

The Claire Marie vein intersects the Two Sisters vein, and the intersection plunges about $58^{\circ} \mathrm{W}$. The trace of the vein intersection is shown on figures 42 and 43. In the mine the Claire Marie vein strikes N. $75^{\circ}-$ $80^{\circ} \mathrm{E}$. and dips an average of about $75^{\circ} \mathrm{S}$.; the vein steepens near the intersection and in the stope above the 179 level. Where observed, the Claire Marie vein is 1 to 4 inches thick and contains gouge and sparse quartz and sulfide minerals.

Both veins are completely oxidized to a limonite-boxwork gossan to a depth below the 105 level and are partly oxidized at the 179 level. They are unaltered so far as known on the 320 level. On the 179 level the galena is surrounded by a thin coating of cerussite, the sphalerite is partly altered to smithsonite, and limonite forms conspicuous films along the margins of all vein

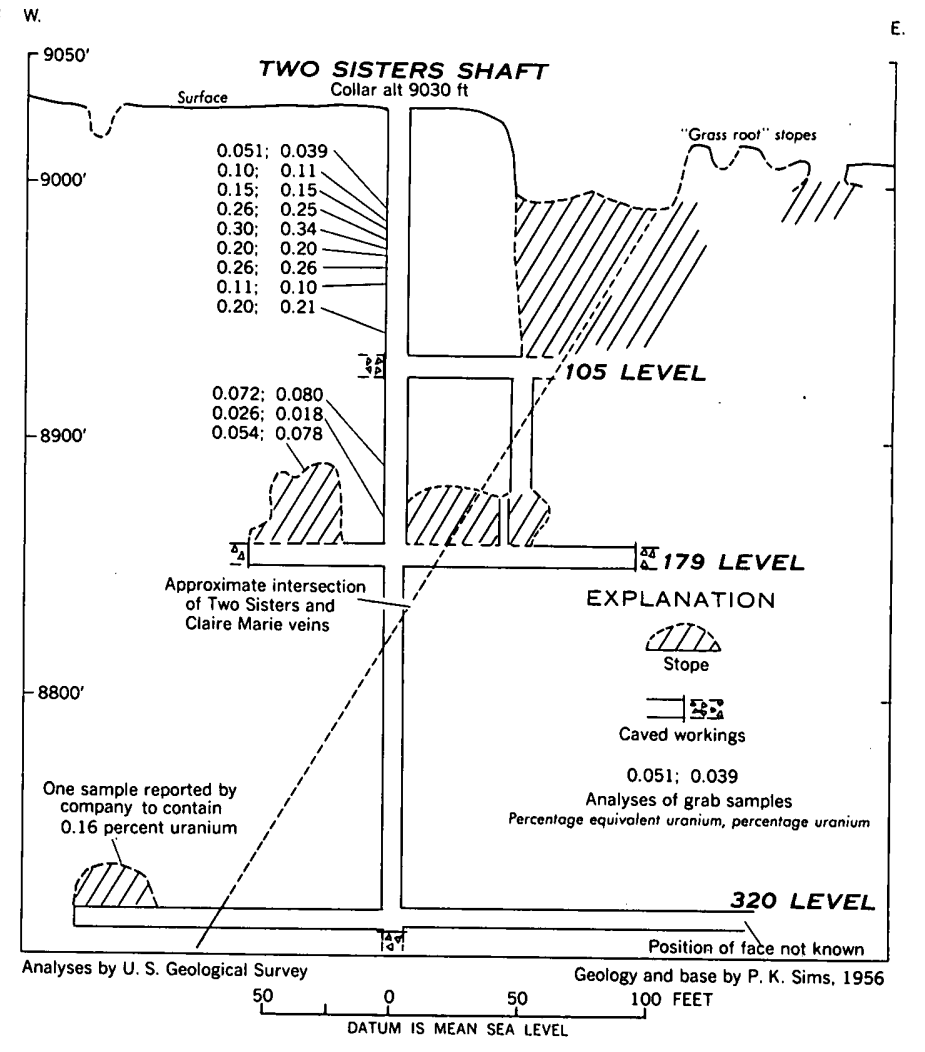

Figure 43.-Vertical longitudinal projection of the Two Sisters vein Two Sisters mine. 
fissures. Presumably, the primary uranium mineral, pitchblende, is completely altered to secondary uranium minerals to a depth of at least 179 feet.

The principal ore shoot in the mine is related to the intersection of the Two Sisters and Claire Marie veins. Ore occurs in both veins and in the broken ground between the veins at and near the intersection. The most valuable ore body that has been mined occurred at the intersection above the 105 level. According to a private company report by Daniel Munday, gold ore valued at about $\$ 100,000$ was extracted from the stope on this ore body. As gold is generally sparse in the lower workings, the ore value was probably due largely to gold enrichment in the oxidized zone.

Uranium occurs in the Two Sisters vein, but it is not known to be present within the mine in the Claire Marie vein. The known occurrences are west of the vein intersection (fig. 43), and possibly constitute a zone of ore shoots that plunges west nearly parallel to the plunge of the intersection.

To a depth of 179 feet the uranium occurs as the secondary minerals kasolite and metatorbernite, but pitchblende probably is present below this depth. The kasolite is associated with hydrous iron-oxides in the oxidized vein and in subsidiary iron-stained fissures adjacent to the vein. Metatorbernite coats fractures in the wallrocks and also is known from dump samples to be disseminated abundantly in altered biotite-quartzplagioclase gneiss (Sims and Tooker, 1955, p. 1680; Sims, Osterwald, and Tooker, 1955, p. 12, 17-18). The disseminated occurrences, however, have not been found in place (in 1956).

\section{JUSTICE HILL AND ADJACENT AREAS}

Pitchblende is present in the Bonanza mine and has been reported from the Justice No. 1 mine, on Justice Hill (pl. 8) ; it also occurs in the Cherokee vein, on the south side of Russell Gulch about two-thirds of a mile southwest of the crest of Justice Hill. Radon is abundant in the Pewabic tunnel, 1 mile northeast of . Justice Hill on the west side of State Highway 119. The deposits at the Bonanza and Cherokee mines have been mined on a small scale, and a small quantity of uranium ore was shipped from the Bonanza mine in 1955. Attempts to recover pitchblende from the Cherokee vein by gravity separation milling methods have not yet (1956) proved to be successful.

.Justice Hill is underlain by an interlayered sequence of biotite gneisses and pegmatite of Precambrian age, which is intruded by irregular bodies of quartz monzonite porphyry of Tertiary age (pl. 8). Immediately north of the map area (pl. 8) bostonite porphyry and quartz bostonite porphyry cut the Precambrian rocks.
The geology of the adjoining areas is closely similar. On Justice Hill, the Precambrian rocks are folded along northeastward-trending axes. Southeast of the Shamrock vein the rocks are tightly folded into nearly isoclinal overturned folds whose axial planes dip steeply, whereas northwest of the Shamrock vein the rocks are gently folded, commonly into more open asymmetric anticlines and synclines.

Two sets of intersecting veins, which strike northeast and east-northeast, are present on Justice Hill. The most prominent and continuous vein set strikes about $\mathrm{N} .45^{\circ} \mathrm{E}$. and dips steeply northwest; these veins are nearly parallel to the axial planes of tight folds. The other vein set strikes about $\mathrm{N} .75^{\circ} \mathrm{E}$., dips steeply northwest and southeast, and cuts across the foliation and fold axes of the country rock.

\section{BONANZA MINE}

Uranium-bearing vein material was found on the dump of the Bonanza mine by M. W. Harrison in 1950. He submitted a sample of the material to the Geological Survey, and it was found to contain 0.32 percent equivalent uranium and 0.026 percent uranium. As a result of the discovery, the mine was examined and mapped by the Geological Survey, first in 1950 and later in 1951. In 1955, 6.64 tons of uranium-bearing material that assayed 0.54 percent $\mathrm{U}_{3} \mathrm{O}_{8}$ was shipped from the mine. ${ }^{13}$

The output of other metals from the mine has been small. The recorded production from the Bonanza mine, including output from the nearby Ace in the Hole and Greenside mines, was 188 tons of ore containing 62 troy ounces of gold, 280 ounces of silver, 216 pounds of copper, 5,089 pounds of lead, and 198 pounds of zinc. ${ }^{34}$

The years of reported activity were: Bonanza mine1913, 1932, 1935, and 1942; Ace in the Hole mine1931-33; and Greenside mine-1912-13, 1916, and 1921.

The Bonanza mine is opened by a shaft, which is inclined steeply south and connects to levels at vertical depths of $64,78,100$, and 170 feet; the 64 level is an adit level (fig. 44). The lowest level was not accessible in 1950 and 1951.

The mine workings are in Precambrian biotite gneisses, the principal variety of which is sillimanitic biotite-quartz gneiss (fig. 45). Several thin conformable granite pegmatites occur in the biotite gneisses. The rocks strike north-northeast and dip steeply, predominantly to the southeast.

Two veins-the Bonanza and the Shamrock-which

${ }^{13}$ Data on production furnished by U.S. Atomic Fnergy Commission. Published by permission.

${ }^{14}$ Compiled from U.S. Bureau of Mines records. Published by per- 


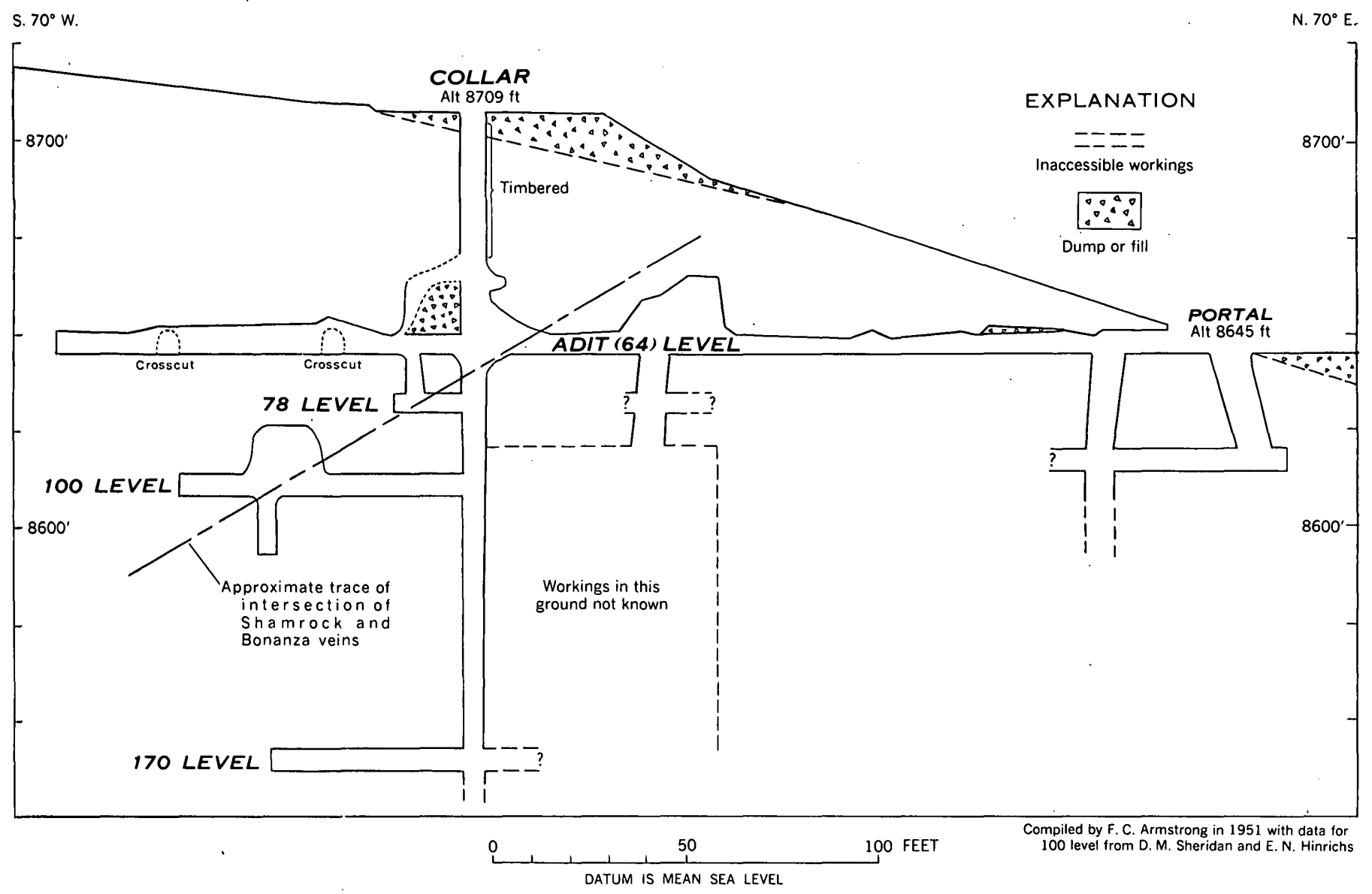

Fiaure 44.- Vertical longitudinal projection of the Bonanza mine, Central City district.

intersect near the shaft on the adit (64-foot) level, have been explored in the mine, but all mining has been done on the Bonanza vein (fig. 45). The Bonanza vein strikes about $\mathrm{N} .70^{\circ} \mathrm{E}$. and commonly dips $60^{\circ}-80^{\circ} \mathrm{SE}$. The Shamrock vein strikes about N. $45^{\circ} \mathrm{E}$. and dips $70^{\circ}$ $\mathrm{NW}$. to $90^{\circ}$. The intersection plunges about $30^{\circ} \mathrm{SW}$., as shown on figure 44 . Both veins are narrow and consist mainly of quartz and pyrite with subordinate amounts of chalcopyrite, sphalerite, and galena. Malachite and azurite occur sparsely in fractures and as an efflorescence on the walls of the adit.level.

Pitchblende occurs at one locality in the mine. On the adit level, pitchblende is present on the footwall of the Bonanza vein from the shaft to a point 8 feet southwest of it, and it extends downdip to the 78 level (fig. 46). Although the Shamrock vein is slightly radioactive at the adit level, it does not contain visible pitchblende. The pitchblende in the Bonanza vein occurs as irregular discontinuous stringers ranging from less than 1 to about 2 inches in thickness. Analyses of selected material are given in table 25. All samples are out of equilibrium-there is insufficient uranium to account for the radioactivity-probably because of leach- ing by acid water, both before and after development of the mine.

A specimen of high-grade pitchblende ore was collected by F. B. Moore from the adit level. The specimen consists of small (less than 1 inch in maximum dimension) irregular masses, narrow veinlets of soft dull

TABLE: 25.-Uranium content of samples from the Bonanza mine

[Analyres by U.S. Geol. Survey]

\begin{tabular}{|c|c|c|c|c|}
\hline $\begin{array}{l}\text { Laboratory } \\
\text { serial su. }\end{array}$ & Location & $\begin{array}{l}\text { Sample } \\
\text { length } \\
\text { (feet) }\end{array}$ & $\begin{array}{l}\text { Equiva- } \\
\text { lent } \\
\text { uranium } \\
\text { (percent) }\end{array}$ & $\begin{array}{l}\text { Uranium } \\
\text { (perce nt) }\end{array}$ \\
\hline $431451+\ldots$. & $\begin{array}{l}\text { Grab sample from dump. } \\
\text { Chip sample from footwall of shaft }\end{array}$ & $\mid--\cdots$ & $\begin{array}{l}11.0 \\
22.0\end{array}$ & $\begin{array}{r}6.05 \\
15.67\end{array}$ \\
\hline $43147^{1}$ & $\begin{array}{l}\text { at adit level. } \\
\text { Chip sample from } 2 \mathrm{ft} \text {. below sample }\end{array}$ & & 24.8 & 15. 13 \\
\hline $45579^{2}$. & $\begin{array}{l}\text { Channel sample cut across 6-in vein } \\
\text { in the east wall of the shaft, } 12 \mathrm{ft} \\
\text { below the track level on the adit } \\
\text { level. }\end{array}$ & 1.0 & .020 & .011 \\
\hline $45580^{2}--$ & $\begin{array}{l}\text { Channel sample from sonth wall } \\
\text { drift, } 5 \mathrm{ft} \text { west of west side of shaft } \\
\text { on adit level. }\end{array}$ & 1.0 & .003 & .002 \\
\hline $58956^{3}$. & $\begin{array}{l}\text { Channel sample cut from same loca- } \\
\text { tion as sample } 45580 \text {. }\end{array}$ & 1.5 & .003 & n.d. \\
\hline
\end{tabular}

1 Sample taken by F. B. Moore.

2 Sample taken by D. M. Sheridan and F. N. Hinrichs.

- Sample taken by F. C. Armstrong.

n.d. means not known. 


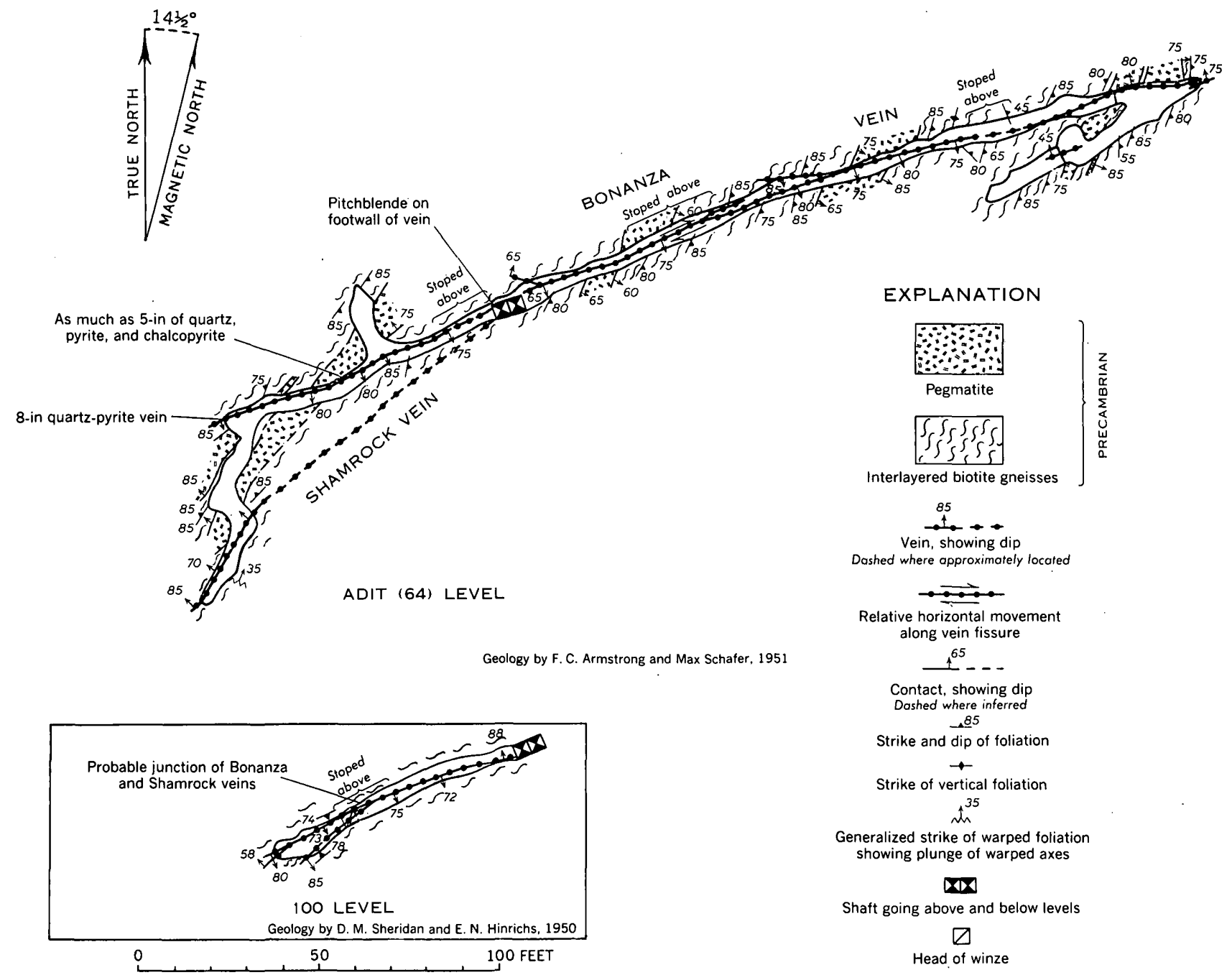

Figure 45.-Geologic maps of the adit (64-foot) and 100 levels, Bonanza mine, Central City district.

black homogeneous pitchblende, and minor amounts of tiny pyrite veinlets-all in altered and pyritized wallrock. The pitchblende has a conspicuous colloform structure. At places in the mine, pyrite veins the pitchblende; at other places pyrite-quartz veinlets cut and offset pitchblende-bearing veinlets. Both the pyrite and pitchblende are older than sphalerite, chalcopyrite, and galena. Most of the pitchblende-bearing ore found on the dump and underground contains local coatings of tiny torbernite crystals which probably formed after development of the mine.

The uranium deposit appears to be localized at the intersection of the Bonanza and Shamrock veins and may rake virtually parallel to the intersection. This cannot be proved, however, until further mining is done below the adit level.

\section{CHEROKEE VEIN}

Pitchblende has been found at two places along the Cherokee vein-in the Cherokee mine and in the Little Annie mine-and a small quantity of pitchblende-bearing ore has been extracted from the Cherokee mine. In 1955 the occurrences had not yet been proved to be of commercial importance.

Pitchblende was first discovered on the dump of the Cherokee mine in 1952 by Kenneth Lewis of Russell Gulch. After the discovery the mine was dewatered and examined and it was found that the pitchblende had come from small veinlets that had been cut in the shaft at a depth of about 65 feet. This showing was developed, largely through financial assistance from the U.S. Atomic Energy Commission, and a few tons of lowgrade ore were extracted from a small stope above the 
108 level (fig. 47). None of this ore was shipped. Subsequent development disclosed another small occurrence of pitchblende-bearing ore on the 216 level, west of the shaft. The pitchblende discovery at the Little Annie mine was made in 1953 by R. R. Hinckley of Russell Gulch; the occurrence has not been explored and nothing is known of its size.

The Cherokee vein is developed mainly by three shafts and a tunnel, from east to west, the Widow Woman (American Girl) shaft, the Cherokee (Spread Eagle) shaft, the Cherokee tunnel, and the Little Annie shaft. The 242 level of the Widow Woman mine connects with the Cherokee shaft (fig. 47). In 1955, all the workings on the vein, except the Little Annie mine, were accessible.

The Cherokee vein is on the north slope of Banta Hill and it can be traced at the surface for a distance of about half a mile. Throughout most of its length it cuts across a tightly folded sequence of interlayered biotite gneisses, but immediately west of the Cherokee mine it cuts both pegmatite and biotite gneisses. At its west end the vein cuts a large body of granodiorite porphyry. Most of the mining has been done on the eastern part of the vein.

The Cherokee vein strikes on the average N. $80^{\circ}-85^{\circ}$ E. and dips about $80^{\circ} \mathrm{N}$., but it varies in strike and dip as much as $20^{\circ}$ (fig. 48). Generally the vein consists of many thin, highly irregular, subparallel, branching or interlacing fractures that contain gouge, quartz, and variable quantities of ore minerals. Horses between closely spaced veins commonly are intensely altered and mineralized, the whole locally constituting ore. In the Widow Woman mine, particularly in the lower workings, the main vein is much wider than at the Cherokee mine and is commonly greater than 2 feet wide. Nearly horizontal slickensides are abundant, particularly on fractures exposed on the drift walls.

The Cherokee is a galena sphalerite vein that contains galena, sphalerite, chalcopyrite, tennantite, pitchblende, and pyrite in a gangue of quartz, rhodochrosite, and gouge. Chalcocite and covellite are locally sparse secondary minerals. Barite was observed on the dump of the Little Annie mine, and purple fluorite occurs sparsely in both the Cherokee and Widow Woman mines. The base-metal sulfides and intergrown gangue occur as massive clots and stringers a few inches to as much as 1 foot wide and as tiny stringers and disseminations in altered wallrocks adjacent to filled fissures. The galena commonly is fine grained, but it also forms larger cubes with curved faces. The sphalerite is an amber to reddish-brown variety which is low in iron. Pitchblende is sparse. It ranges from hard black botryoidal material to a soft porous locally sooty vari- ety. Pyrite is sparse but nearly as abundant as galena.

At most places the vein is oxidized to a depth of about 40 feet. Abundant chalcocite was formed, in part at least, after the opening of the mine, as a result of surface water that accumulated in the abandoned mine workings above the vein and moved toward the bottom of the nearby Widow Woman shaft, which is lower in altitude. Irregular clots of brownish-gray to greenish-gray chalcedonic quartz are associated with this chalcocite.

The principal precious-metal and base-metal ore shoot known in the vein is in the Widow Woman mine (fig. 47 ) ; it occurs at the junction of the Cherokee (Widow Woman) vein and a northeastward-trending vein named vein $A$ which possibly is part of the Gold Lode. Minor ore shoots that have maximum dimensions of only a few tens of feet occur locally at deflections in the strike or dip and at vein splits. The ore within the major shoot, as determined by assays along a vein length of 135 feet and an average width of 3.5 feet, contains an average of 0.28 ounce of gold per ton, 5.2 ounces of silver per ton,

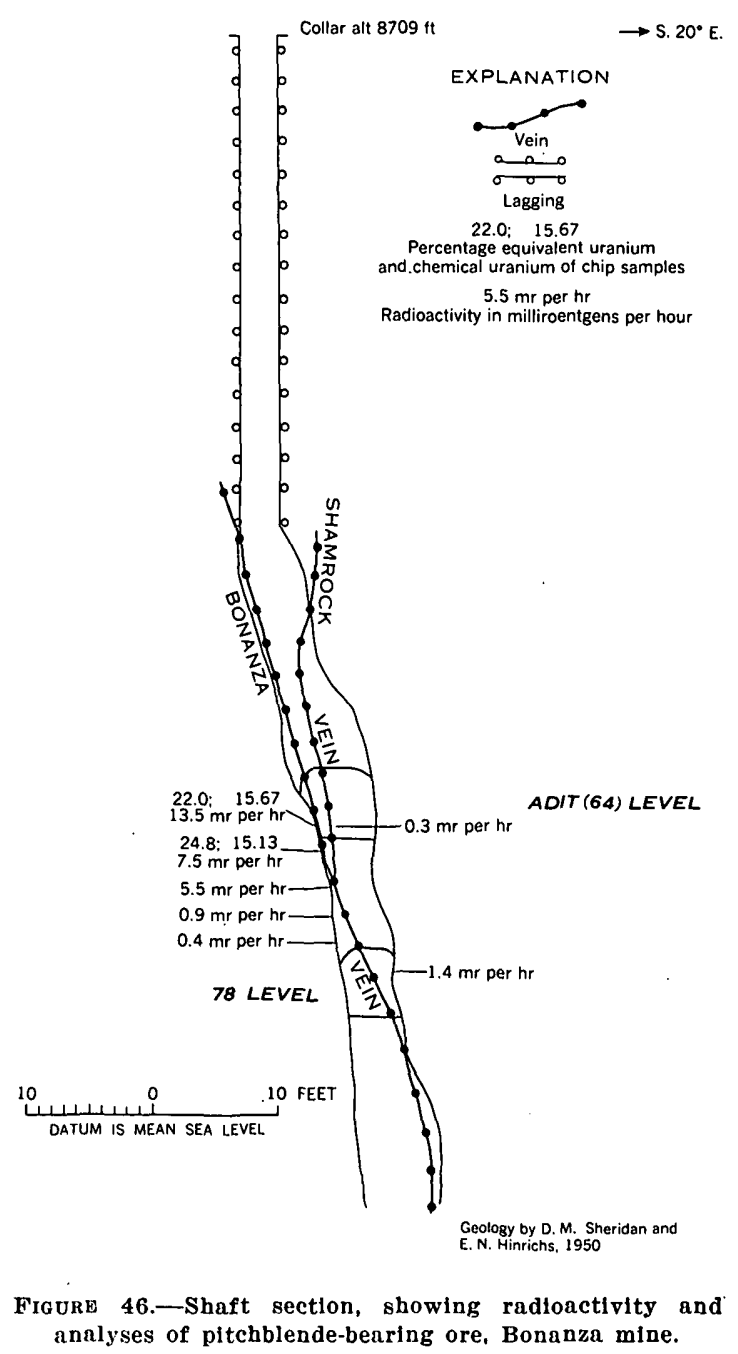




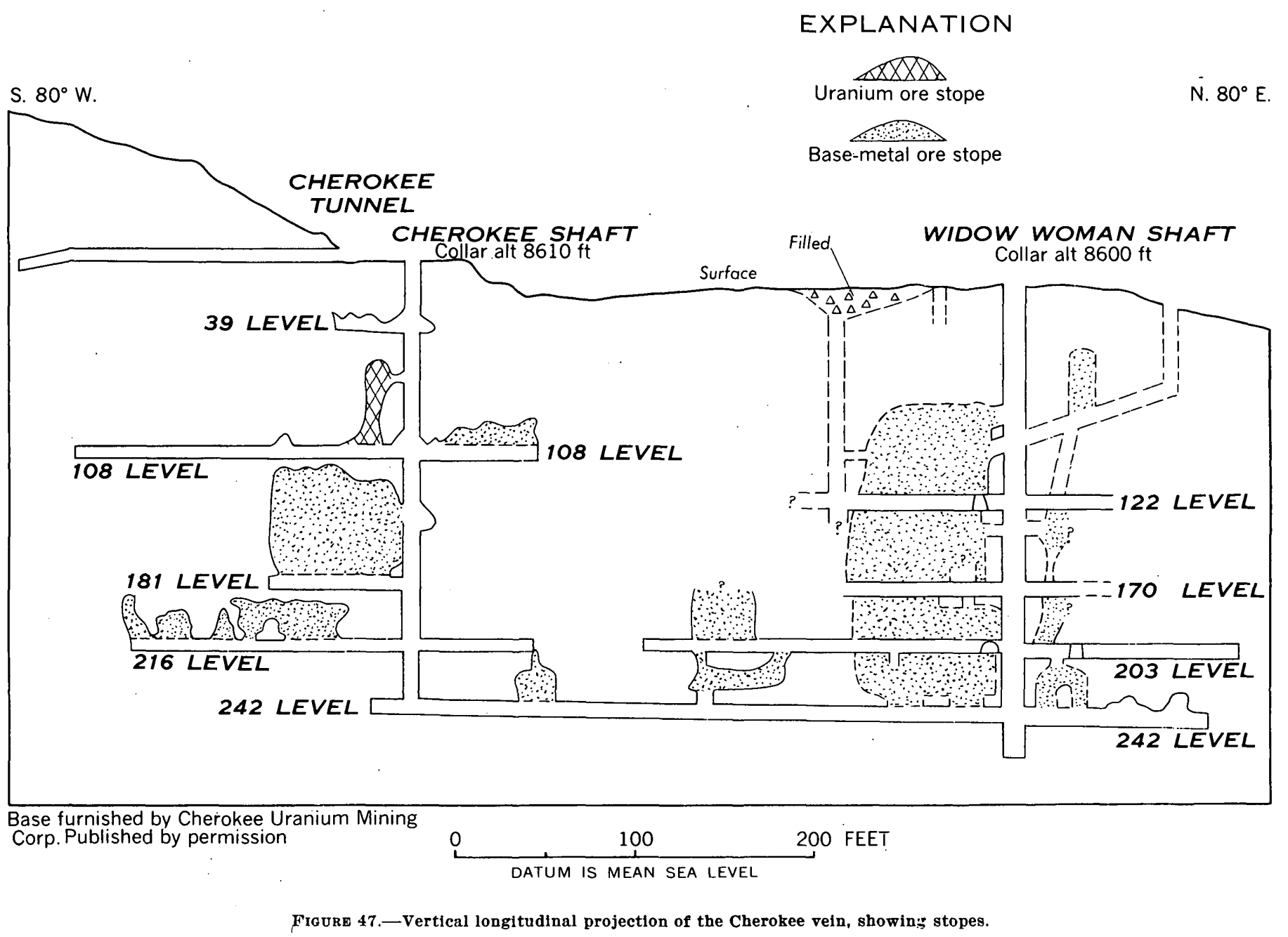

3.1 percent lead, and 0.16 . percent copper. Zinc occurs in about the same abundance as lead.

The pitchblende ore shoot, mined from the small stope above the 108 level of the Cherokee mine (fig. 47), has a maximum height of about 40 feet and a maximum breadth of about 15 feet. The ore within the shoot occurs largely in a single fracture within the vein, as shown in figure 49 ; it ranges in thickness from 0 ito slightly more than 1 foot. Analyses from the ore body are given on figure 49. A thin, lenticular layer of pitchblende-bearing ore was found on the wall of the 216 level, about 100 feet west of the shaft. Specimens from this layer were shown to the writer by R. R. Hinckley; they show hard black lustrous pitchblende in discontinuous stringers as much as three-quarters of an inch thick and 6 inches long. The pitchblende is associated with sparse pyrite, galena, and quartz.

The pitchblende was deposited virtually contemporaneously with sparse quartz and it is cut by tiny pyrite veinlets and by later base-metal sulfides. A few specimens taken from the dump contain sooty pitchblende, which occurs as vug fillings. They came originally from the Cherokee shaft at a depth of about 65 feet.

The pitchblende occurrences in the Cherokee vein appear to be small and widely spaced, and they will probably not prove to be commercially valuable. Some pitchblende can be recovered, however, in conjunction with the mining and beneficiation of the precious metalbearing base-metal ores. 


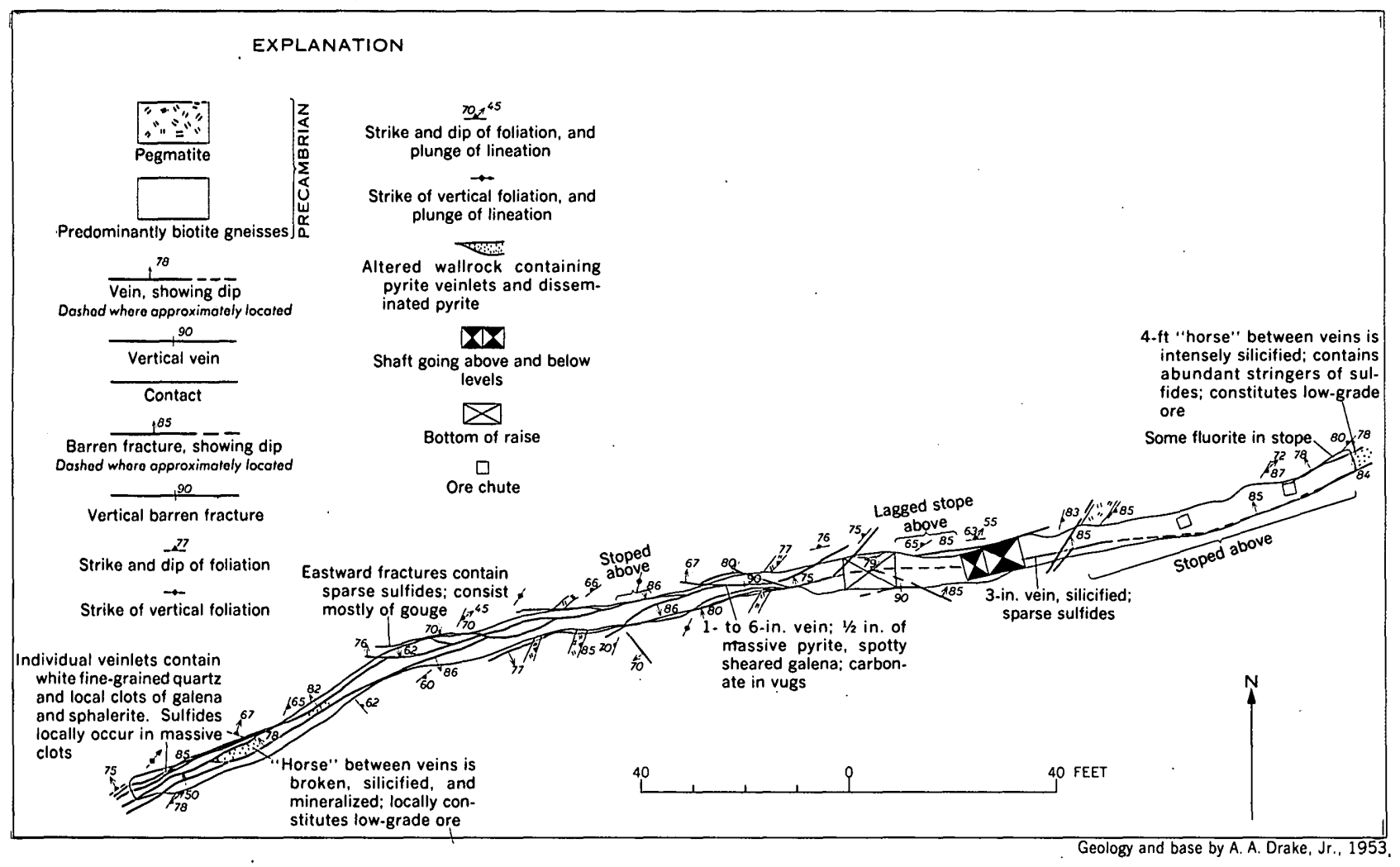

Figure 48.-Geologic map of the 108 level, Cherokee mine, Central City district.

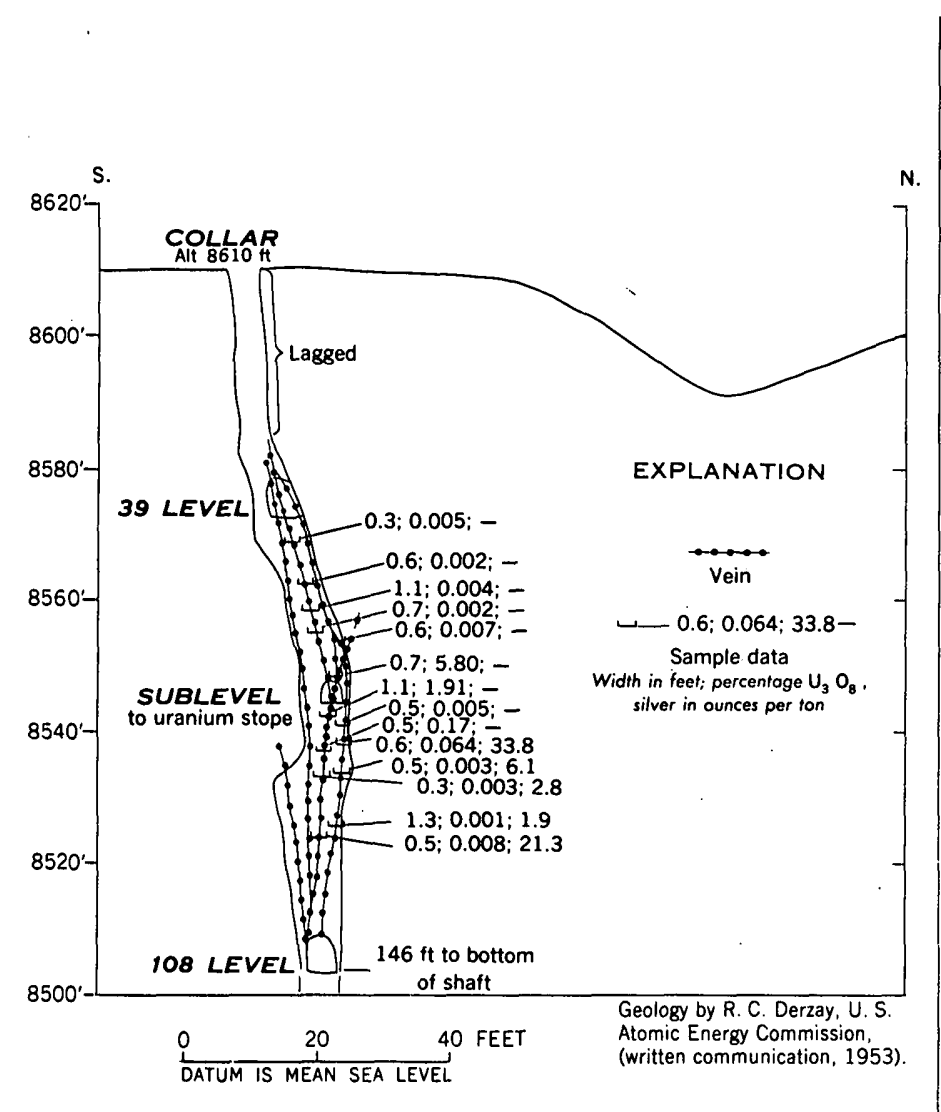

Fiquan 49.-Section of the upper part of the Cherokee shaft, showing occurrence of pitchblende.
PE'WABIC TUNNEL

BY A. A. DRAKE, JR.

The Pewabic tunnel is on the west side of North Clear Creek about 1 mile northeast of Justice Hill and 11/8 miles southeast of Black Hawk. It extends for 1,233 feet on a bearing of about S. $55^{\circ}$ W. (fig. 50 ). At a distance of 1,183 feet from the portal, a 400 -foot cross-drift is turned from the principal workings on a bearing of $\mathrm{S}$. $7^{\circ}$ E. From the face of the principal drift a 300 -foot crosscut is driven on a bearing of N. $60^{\circ}$ W. A few small stopes and raises have been driven into the back of the tunnel; their locations are shown in figure 50. P. R. Alsdorf ${ }^{15}$ reports that 900 tons of ore that sold for $\$ 76,000$ was extracted from the mine.

The wallrock consists of almost equal proportions of muscovite-tourmaline pegmatite and interlayered biotite gneisses. Generally the rocks trend northeast and dip steeply to the southeast. The rocks are probably deformed into a series of tight, overturned northeastward-plunging folds, but because of dirty walls the exact relations were not worked out. In the cross cut at the western part of the mine, a series of asymmetrical drag folds is outlined by the rock units. The flat limbs of these folds trend east-northeast.

The Mary Miller vein, the principal vein developed by the mine, is intersected by the tunnel about 120

${ }^{15}$ Alsdorf, P. R., 1928, Report to the Master Key Tunnel Association, unpublished private mining report on file in the Denver Public Library. 
feet from the portal. It has an average strike of about N. $55^{\circ}$ E., but about 800 feet from the portal it swings to a strike of $\mathrm{N} .70^{\circ} \mathrm{E}$. It dips $65^{\circ}-85^{\circ} \mathrm{NW}$, averaging about $75^{\circ}$. The vein is made up of one principal fissure and many branches; most branches pass into the walls, but some loop and reunite with the trunk vein. Most of the branches are parallel to the foliation in the wallrock. The vein ranges from 6 to 24 inches in width, is largely barren, and consists for the most part of sheared and altered wallrock. In a few places the vein contains as much as 3 inches of quartz and galena, and uncommonly a little tennantite.

About 200 feet from the portal the Mary Miller vein is cut and displaced by a vein fissure that strikes $\mathrm{N}$. $37^{\circ} \mathrm{W}$. and dips $78^{\circ} \mathrm{NE}$. (fig. 50). This vein is 18 to 24 inches wide and filled by gouge that contains a few specks of galena. The east segment of the Mary Miller vein has been shifted 15 to 20 feet to the northwest along this filled fault. To the southwest along the drift, the Mary Miller vein is cut and offset by several other faults that strike north-northwest or north-northeast. Without exception, the apparent horizontal displacement of the vein is less than 10 feet.

The cross-drift which begins 1,183 feet from the portal is driven on a vein that strikes about $N .7^{\circ} \mathrm{W}$. and dips $80^{\circ} \mathrm{E}$. to $90^{\circ}$. This vein is nearly barren and is filled by 2 to 6 inches of iron-stained gouge.

The crosscut part of the tunnel cuts two veins that are 45 and 170 feet from the breast of the Mary Miller drift (fig. 50). These veins are developed by short drifts and consist only of iron-stained gouge and crushed rock. They strike to the northeast and dip steeply to vertically southeast.

In 1950, R. U. King of the Geological Survey found that the Pewabic tunnel contained radon gas, but because radioactivity detecting devices became contaminated in a short time he could not isolate the source of the radon. In 1954, the writer collected several random samples of vein material and rock from the mine which were analyzed in an attempt to find the radon source. The equivalent uranium content of these samples is given in table 26. Although the results are inconclusive, it is possible that the radon is derived from the disintegration of uraninite or another radioactive mineral sparsely disseminated in the pegmatite or biotite gneiss wallrocks, and that the relatively large quantities of the gas result from a large quantity of low-grade rock present in the mine. Two samples of partly disintegrated rock, largely biotite gneiss, taken from the two most highly radioactive areas on the dump, assayed
0.004 and 0.012 percent equivalent uranium. The latter sample contained 0.010 percent uranium, an abnormal quantity of uranium for biotite gneiss. TABLE 26.-Equivatent uranium content of samples from the
Pewabic tunnel

\begin{tabular}{|c|c|c|}
\hline Material & $\begin{array}{c}\text { Distance } \\
\text { from portal } \\
\text { (in feet) }\end{array}$ & $\begin{array}{l}\text { Equivalent } \\
\text { uranium } \\
\text { (percent) }\end{array}$ \\
\hline Mary Miller vein.. & 140 & 0.004 \\
\hline $\begin{array}{l}\text { Pegmatite............ } \\
\text { Cross vein }\end{array}$ & $\begin{array}{l}130 \\
189\end{array}$ & .006 \\
\hline Mary Miller vein & 220 & .005 \\
\hline Branch vein & 220 & .003 \\
\hline Cross vein & & .005 \\
\hline Pegmatite & $\begin{array}{l}270 \\
400\end{array}$ & .004 \\
\hline Do & 500 & .005 \\
\hline $\begin{array}{l}\text { Do.... } \\
\text { Do.... }\end{array}$ & $\begin{array}{r}990 \\
1,190\end{array}$ & .005 \\
\hline
\end{tabular}

SILVER HILL AREA

Deposits of secondary uranium minerals have been mined on a small scale at the Blackhawk I code No. 2 claim, and during 1955 about 40 tons of low-grade uranium ore was stockpiled. Primary uranium deposits can be expected at depths probably below 100 feet. For a description of the geology of Silver Hill, the reader is referred to the report by Sims, Drake, and Tooker (1963).

\section{BLACKHAWK LODE NO. 2 CLAIM}

In 1954 radioactivity was found on the Blackhawk I sode No. 2 claim by John H. Turner of Black Hawk, and in 1955 the showings were explored by the Minerals Exploration Co. of California. During the work about 40 tons of low-grade uranium ore was extracted from a 130-foot adit (fig. 52) and a 45-foot shaft (fig. 51). The ore consisted entirely of secondary uranium minerals from oxidized veins; primary uranium minerals were not found.

The radioactivity occurs on two intersecting galenasphalerite veins-the Silent Friend, which strikes N. $50^{\circ}-60^{\circ} \mathrm{E}$., and a vein herein called the Blackhawk vein-possibly the southwest extension of the Pocahontas vein, which strikes about N. $35^{\circ}$ E. The radioactivity on the Silent Friend vein is due mainly to kasolite; the radioactivity on the Blackhawk vein is caused mainly by metatorbernite which is dispersed through altered amphibolite adjacent to the vein.

The Silent Friend vein is developed by a 45 -foot vertical shaft that was sunk in 1955 , several shallow prospect pits, and a short adit level; the portal of the adit is 


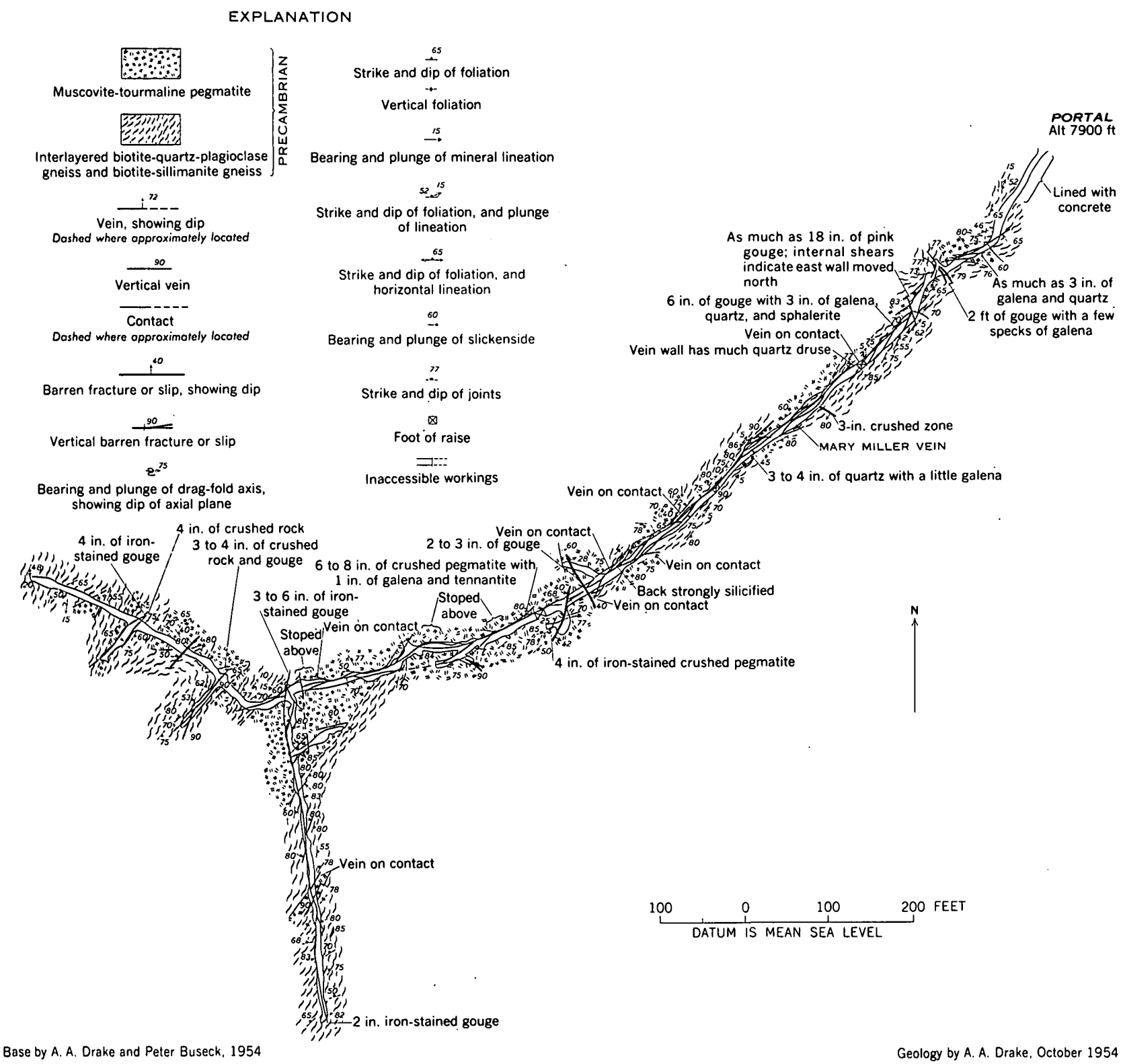

Figure 50.-Geologic map of the Pewabic tunnel, Central City district, Gilpin County, Colorado.

about 400 feet southwest of the shaft. The Blackhawk vein is developed only by the adit (fig. 52). The adit level was advanced from 60 feet to 130 feet in 1955. Both mine openings were mapped in 1955.

The wall rock of both veins is dominantly amphibolite, which constitutes a large, generally flat-lying body that caps the southeast part of Silver Hill. Several small bodies of pegmatite and a few thin layers of biotitequartz-plagioclase gneiss occur throughout the amphibolite. West of the adit the veins pass into microcline-bearing gneiss.

The Silent Friend vein strikes N. $50^{\circ}-60^{\circ}$ E. and dips nearly $90^{\circ}$. It has been traced on the surface for 1,300 feet. Abnormal radioactivity is found sporadically along the vein for 700 feet. The highest surface anomaly was explored by the shaft; other.smaller anomalies are present near the adit. Sparse radioactive vein material is present on the dump of the Silent Friend shaft, which is reported to be 105 feet deep.

The shaft on the Blackhawk Lode No. 2 claim develops a small uranium ore shoot that has a height of 23 feet and an average width of about 15 feet (fig. 51). About 8 tons of ore were extracted from the shoot. The ore within the shoot occurs locally along several subparallel or intersecting fractures; it is in small stringers, commonly 1 inch or less wide, and as much as 15 feet 


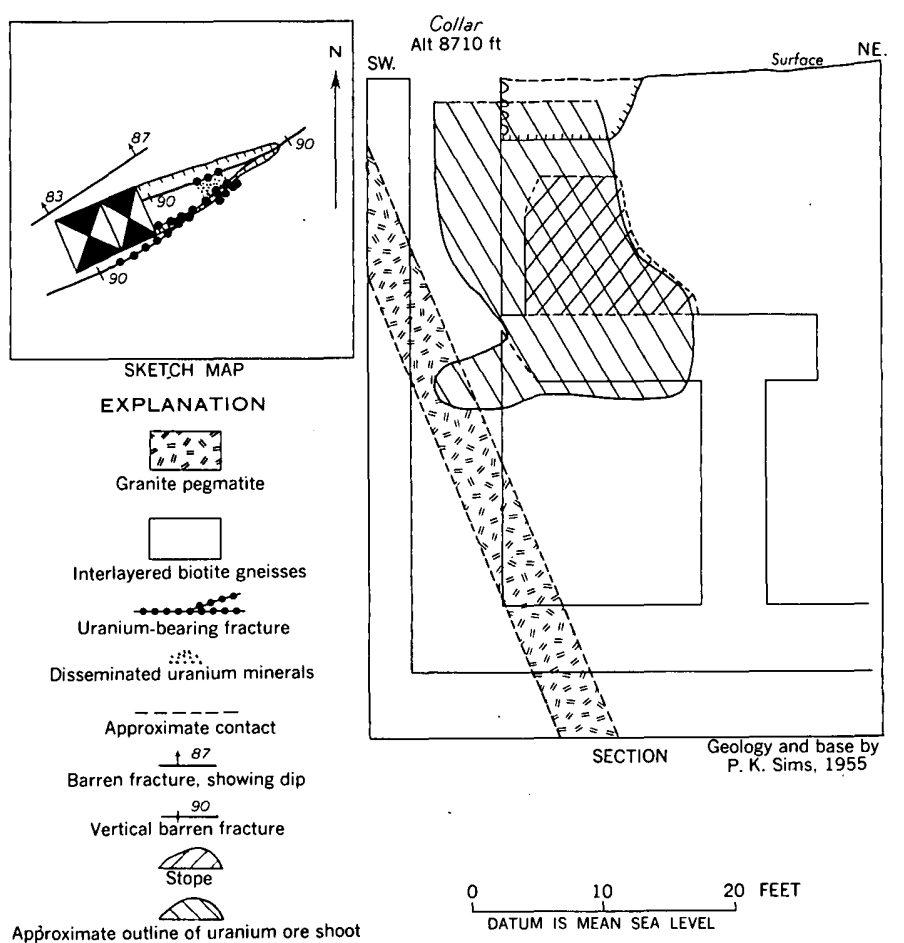

Figurv 51.-Sketch map and section of shaft workings, Blackhawk Lode No. 2 claim, Central City district.

long. A sketch map of a surface trench, 5 feet deep (fig. 51), shows in detail the relation of the uranium minerals to the fractures. The principal tonnage at this altitude was extracted from a pod of ore between two intersecting fractures. The veinlet on the southwest wall continued to a depth of about 20 feet and locally was as much as 5 inches wide. An analysis from the veinlet at a depth of 17 feet gave 0.85 percent equivalent uranium and 0.96 percent uranium. At a depth of 20 feet, in the southwest corner of the shaft, another small pod of uranium ore was found at the junction of two uranium-bearing fractures that converged upward; this pod appeared to rake gently northeast.
Kasolite is the principal uranium mineral in the ore shoot. A small quantity of meta-autunite was found along a fracture in the wallrock on the southwest wall of the shaft at a depth of 27 feet. The kasolite is associated with limonite in vuggy, oxidized veins. The average grade of the uranium ore extracted from the shoot is about 0.30 percent uranium. Analyses of samples taken from the shoot are given in table 27.

In the fall of 1955,2 diamond core holes were drilled from the surface and 2 were drilled from the bottom of the shaft to test for an extension of the ore shoot at a depth of about 100 feet. One surface hole intersected several closely spaced stringers of uranium-bearing material several feet into the south wall of the Silent Friend vein, but the relation of these showings to the main vein is not known. The other three cores were barren.

The Blackhawk vein, as exposed in the adit level (fig. 52 ), strikes N. $35^{\circ}$ E. and dips $75^{\circ}-85^{\circ}$ NW. Seventyfive feet from the portal of the adit it cuts, but does not displace, the Silent Friend vein. The Blackhawk vein is abnormally radioactive along most of its exposure, but the uranium is concentrated primarily in intensely altered amphibolite wallrock, adjacent to the uraniumbearing fractures. The Silent Friend vein and altered amphibolite adjacent to the vein similarly are abnormally radioactive, as shown in figure 52. The radioactivity in the oxidized limonitic veinlets is due mainly to kasolite; the radioactivity in the altered amphibolite is due to metatorbernite and minor amounts of metaautunite.

The metatorbernite occurs only in a highly altered phase of amphibolite that consists largely of soft, green clay that when wet resembles olive-green soap. Less intensely altered phases are barren or nearly so. Because the uranium occurs only in the intensely altered phase, three types of amphibolite, distinguished by the degree of alteration, were mapped (fig. 52). The most intensely altered phase-massive green clay-occurs

TABLE 27.-Analyses of uranium-bearing vein from shaft on the Blackhawk Lode No. 2 claim,

[Analyses by U.S. Geol. Survey; analysts: C. G. Angelo, Mary Finch, James Wahlberg, E. C. Mallory, Jr., and H. E. Bivens]

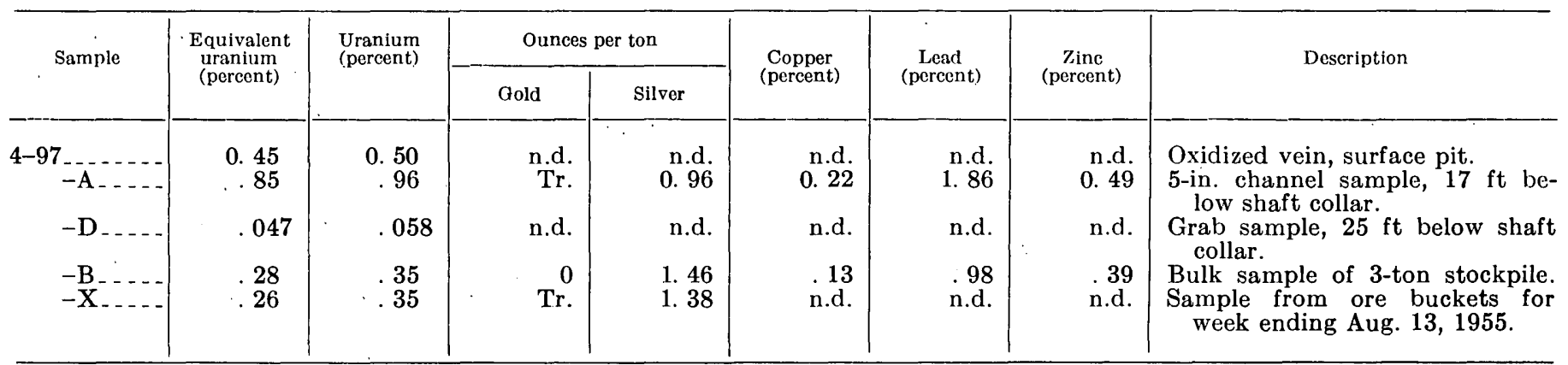

n.d. means not determined.

0 means not present. 
between and adjacent to veinlets and seems to be more abundant where the fractures are closely spaced. Most of the metatorbernite is erratically dispersed through the host rock, but some is concentrated along minute fractures or along the margins of pods of green clay. Bulk samples show that the uranium content of this type of rock ranges from 0.04 percent to 0.25 percent and averages about 0.10 percent. The partly altered amphibolite, in which plagioclase is changed to clay but biotite remains, is nearly barren; metatorbernite, where present, occurs only along fractures. The fresh or only slightly aItered amphibolite is barren.

About 25 tons of metatorbernite-bearing rock was mined from the adit level. About 3 tons of this material contained an average of 0.20 percent equivalent uranium and 0.26 percent uranium. The remainder is estimated to contain 0.15 percent uranium or less. Assays of material taken from the adit level are shown in figure 52.

\section{POWHATAN TUNNEL}

By A. E. DEARTH

The Powhatan tunnel is a quarter of a mile north of the junction of State Highways 279 and 119 at Black Hawk. The portal is on the east side of North Clear Creek, about 100 feet above the road level, at an altitude

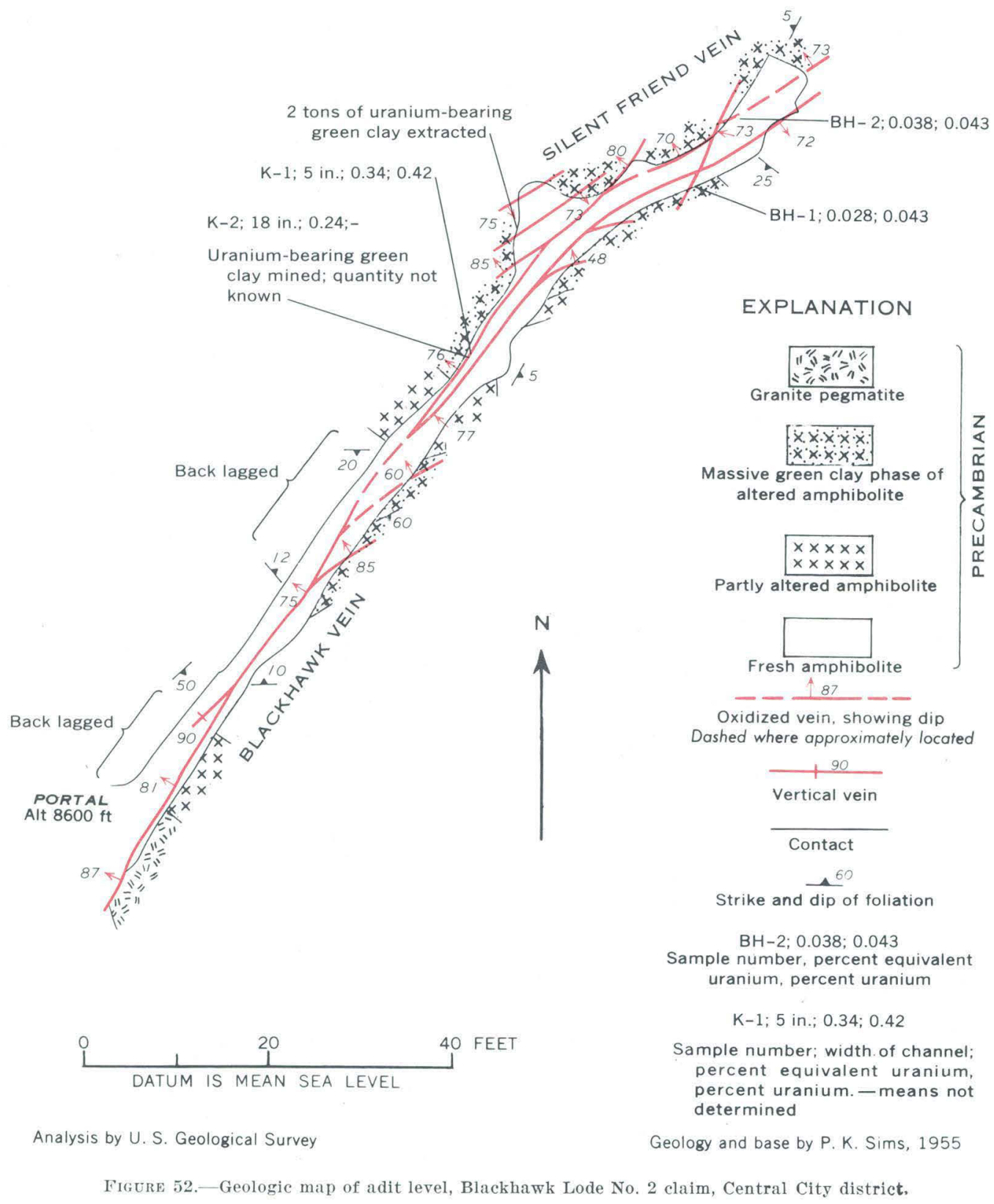




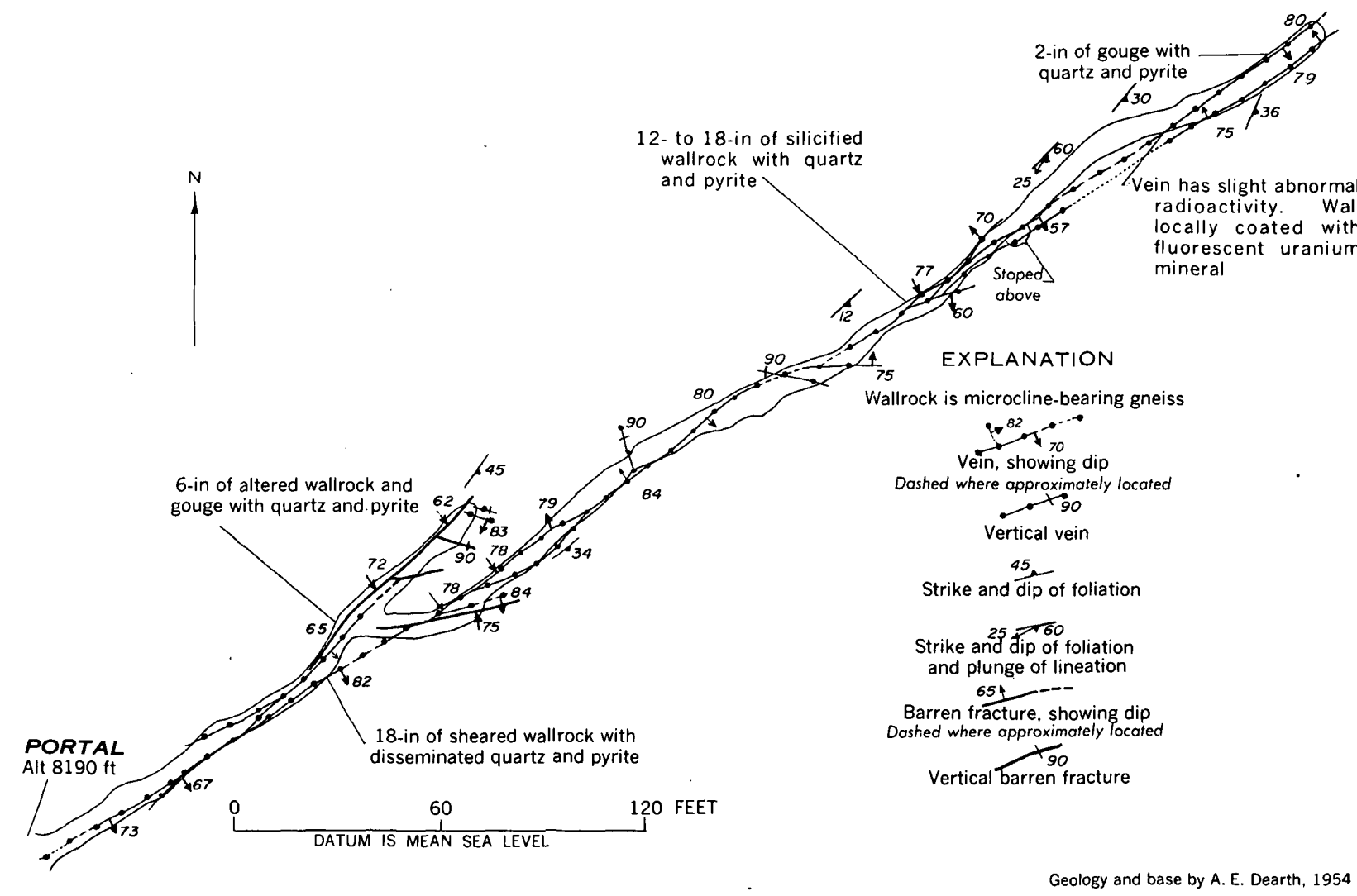

Figure 53.--Geologic map of the Powhatan tunnel, Central City district.

of 8,190 feet. The tunnel bears N. $35^{\circ}$ E. for 445 feet (fig. 53). A small stope is present 335 feet from the portal. Although the property has not been productive, it is of interest because of local efflorescence of a uranium mineral on the mine walls and because the tunnel is about 800 feet southwest from and about 500 feet below the Blackhawk Lode workings (p. 88), which contain uranium deposits of potential importance.

The country rock is microcline-bearing gneiss, which at places contains thin conformable layers of pegmatite. The foliation of the gneiss strikes N. $35^{\circ} \mathrm{E}$. and dips $30^{\circ}-60^{\circ} \mathrm{SE}$. The gneiss is cut by subparallel northeast-trending fractures filled with gouge, quartz, and pyrite; the fractures trend parallel to the foliation of the country rock but have a consistently steeper dip.

The main vein fissure cut in the Powhatan tunnel strikes N. $55^{\circ}$ E. and dips $65^{\circ}-80^{\circ}$ SE.; it is relatively uniform in strike and dip. The fissure is sparsely mineralized and commonly thin. It consists of 1 to 18 inches of quartz, disseminated pyrite, and abundant gouge; at places gouge constitutes the entire fracture filling. Iocally the wallrock is altered and contains disseminated pyrite. Quartz and pyrite are the dominant vein minerals, with lesser amounts of chalcopyrite. Thin subparallel fractures that split from the main vein typically consist of gouge containing small amounts of quartz and disseminated pyrite.

The mine walls are locally coated with an efflorescence of a green to yellowish-green uranium mineral; the mineral also occurs locally in the vein. Anomalous radioactivity was found in the main vein on the south wall, about 45 feet from the face of the tunnel. A selected grab sample of efflorescent coating on the walls from this location contains 0.050 percent equivalent uranium and 0.096 percent uranium.

\section{LAWSON-DUMONT-FALL RIVER DISTRICT}

By C. C. HAWLEY and F. B. MOORE

Uranium occurs at several widely spaced localities in the Lawson-Dummont-Fall River district, and the deposits in the Fall River area and near Lawson are of economic interest. Other known occurrences, whose locations are shown on plate 3 , seem to be small. but few have been accessible for examination.

\section{FALL RIVER AREA}

Pitchblende is present in the Mary, Almaden, and Golconda mines, on the south side of Fall River, and anomalous radioactivity of unknown source is found at the Pennsylvania, Standard, Seven-Forty, Gold 
Quartz, and Ida Mare mines (pl. 3). The relations of the pitchblende-bearing veins in the Mary, Almaden, and Golcondia mines are shown in figure 54 . The pitchblende at the Golconda mine is, so far as known, the soft sooty variety, and some of the mineral at the Almaden mine also is sooty. Although some pitchblende ore was mined at the Almaden mine in 1953-54, no ore was shipped. The deposits in the Mary, Almaden, and Golconda mines are localized within a single type of wallrock, garnetiferous lime silicate gneiss.

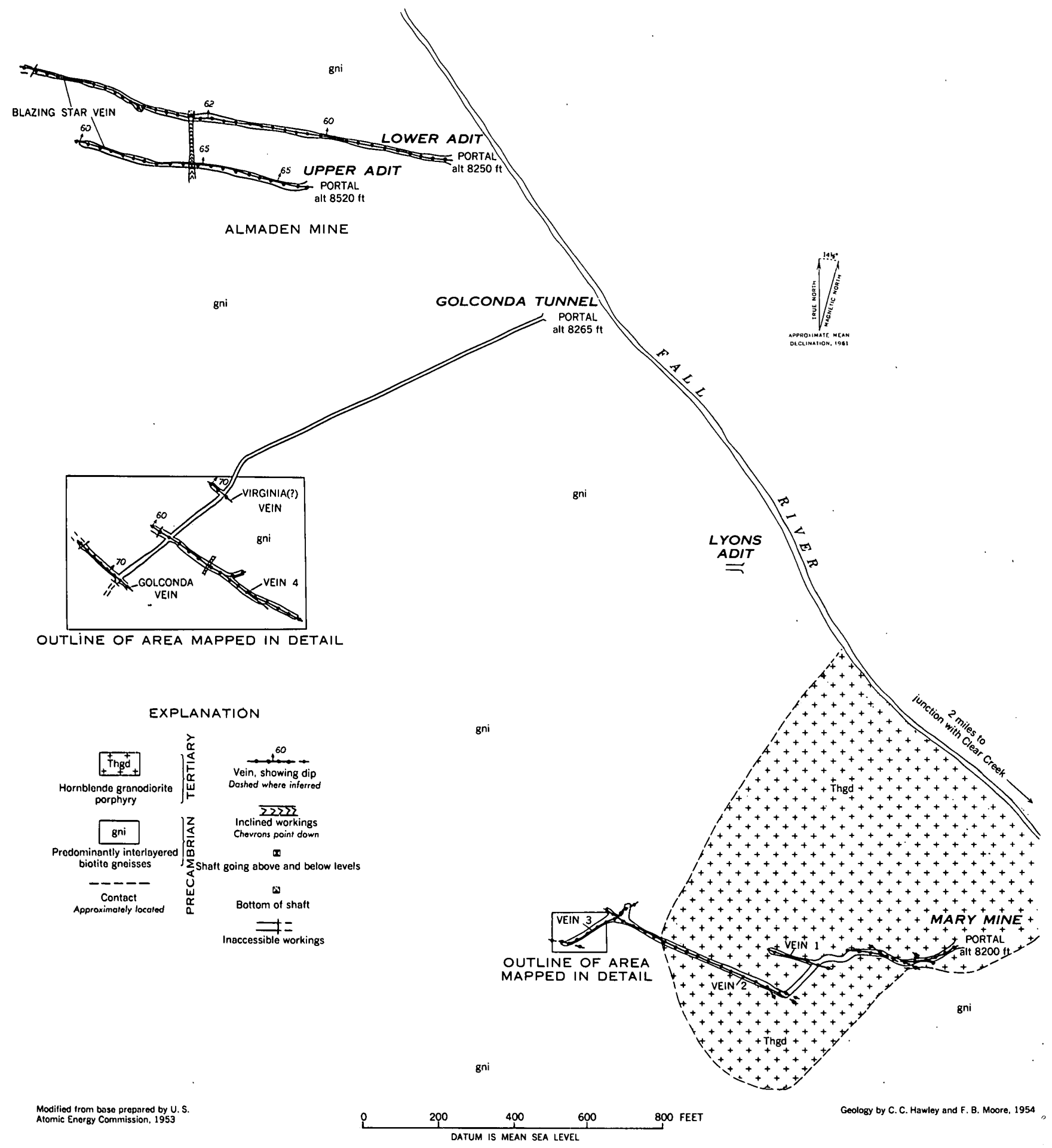

Figure 54.-Composite map showing the relation of mines containing pitchblende deposits, Fall River area. 


\section{AIMADEN MINE}

The Almaden mine is on the southwest side of Fall River, 2.5 miles above its junction with Clear Creek. The workings consist of two principal drift adits and a shaft, which are on the Blazing Star vein (fig. 54). The portal of the lower adit is near the stream bed, at an altitude of 8,250 feet; the adit is caved 1,150 feet from the portal but is reported by Bastin and Hill (1917, p. 316) to be 1,300 feet long. The upper adit, which is 620 feet long, is at an altitude of 8,520 feet. The shaft, whose collar is at an altitude of 8,760 feet, intersects the upper and lower adits at distances of 310 and 700 feet respectively from their portals (fig. 54). The total recorded production from the mine for the reported years of mining activity, 1904, 1906-10, 1912$15,1917,1919-24,1926-29$, and 1934 , is 1,064 tons of ore containing 205 troy ounces of gold, 45,041 ounces of silver, 1,315 pounds of copper, 48,227 pounds of lead, and 7,329 pounds of zinc. ${ }^{16}$

The mine workings intersect a sequence of interlayered biotite gneisses, which locally are migmatitic; the sequence contains layers of granite gneiss and pegmatite, amphibolite, and garnetiferous lime silicate gneiss. Most of the layers within the biotite gneiss are 10 feet or less thick, but some are as much as 50 feet thick. The rocks are folded into many small northeastward-trending anticlines and synclines that plunge gently to the northeast or southwest.

The Blazing Star vein strikes about N. $80^{\circ} \mathrm{W}$. and dips about $60^{\circ} \mathrm{NE}$. Throughout most of its exposed part, the vein is a single fissure 2 inches to 2 feet wide which shows but little variation in strike. Although the vein splits and rejoins in a few places, branches from the vein are rare; only one branch was followed in mining (for about 30 feet). On both adit levels there are several small stopes, especially in the area between the shaft and 250 feet east of it.

The Blazing Star vein contains galena, sphalerite, chalcopyrite, tennantite, ruby silver, pitchblende, niccolite and some pyrite as primary ore minerals and quartz, carbonate, and barite as gangue. The vein was worked for its silver content, and some of the ore reportedly was very high grade. Bastin and Hill (1917, p. 317) report veinlets containing native silver, proustite, pearceite, cerargyrite, and fine-grained chalcopyrite that cut galena-pyrite ore in a specimen from within 200 feet of the surface. These late minerals are supergene in origin and probably account for the richness of some of the ore. Silver values of as much as several thousand ounces to the ton have been reported.

${ }^{16}$ Compiled from U.S. Bureau. of Mines records. Published by permission.
The gold content is low, rarely exceeding 0.3 ounce per ton.

Pitchblende is found at four places in the mine. In the lower adit, 520 feet from the portal, thin veinlets of hard pitchblende occur on the hanging wall of the vein. The veinlets are a quarter of an inch or less thick and are exposed for only a few feet along the drift. At 1,070 feet from the portal, sooty pitchblende occurs in a veinlet on the footwall side of the vein. Both occurrences of pitchblende on this level are in branch veins that pass into the walls. In the upper adit, veinlets of pitchblende occur at two places, 400 and 500 feet respectively from the portal. The pitchblende at both places is exposed for 15 to 20 feet along the drift and has been explored by raises to a height of 30 to 40 feet above the level. Most of the pitchblende is the soft, sooty variety, but small quantities of hard pitchblende occur locally. The pitchblende veinlets cut fractured pyrite but are not closely associated with galena-sphalerite, which is present in the same vein 30 feet away.

The pitchblende, as seen in polisned surfaces, forms discrete stringers that commonly cut altered wallrock: It occurs dominantly in veinlets that consist of aggregates of spheroidal grains; at places niccolite, largely altered to pararammelsbergite(?), and sparse chalcopyrite are intergrown with the pitchblende. The other sulfide minerals, excepting some pyrite, are distinctly later than the pitchblende.

As the pitchblende occurrences in the mine are localized in garnetiferous lime silicate gneiss wallrocks, further exploration should be directed toward the ground where this rock constitutes the vein walls.

\section{GOLCONDA TUNNEL}

The Golconda tunnel, 3,150 feet northwest of the Mary mine (fig. 54), was driven to develop the Golconda and other veins that crop out on the ridge between Fall River and Spring Gulch. The tunnel workings consist of a southwestward-bearing crosscut and drifts on four veins (fig. 55). In 1953 a winze was sunk on vein 4 to a depth of about 90 feet to explore a pitchblende-bearing ore shoot.

A small quantity of gold, silver, and copper has been produced from the tunnel. The recorded production from the Hidden Treasure mine (Golconda vein) for $1902 \cdot$ and $1908-12$ was 271 tons of ore containing 434 troy ounces of gold, 3,604 ounces of silver, and 6,201 pounds of copper. ${ }^{17}$

The wallrock exposed in the Golconda tunnel is mainly interlayered biotite gneisses, which at places are migmatitic. Lesser quantities of pegmatite, biotite-

${ }^{17}$ Compiled from U.S. Bureau of Mines records. Published by permission. 


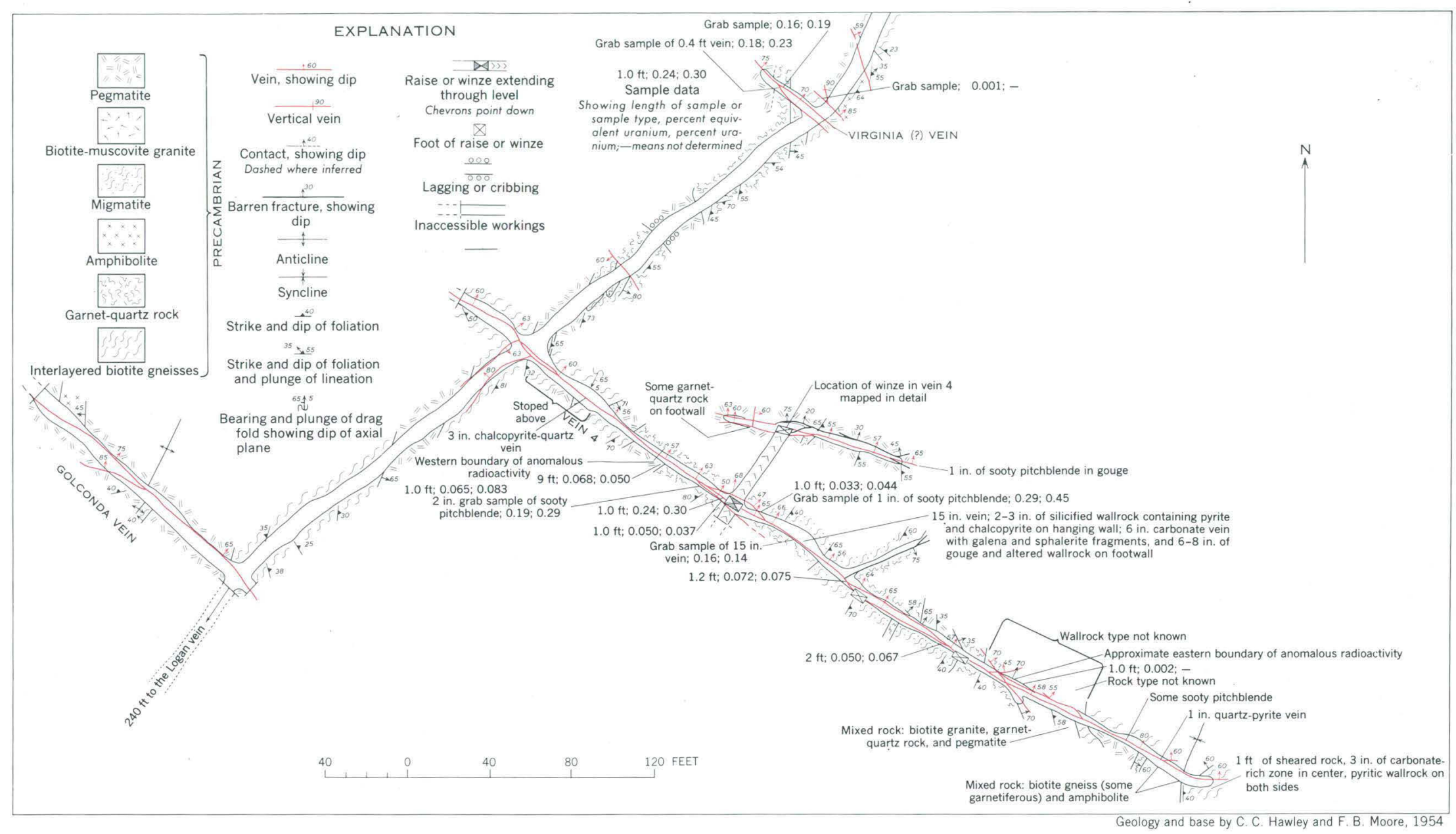

Figure 55.-Geologic map of part of the Golconda tunnel, Fall River area, Clear Creek County, Colo. 
muscovite granite, and amphibolitic and garnetiferous lime silicate gneisses are present. Some of the biotite gneisses contain garnet. The garnetiferous lime silicate gneiss occurs as layers as much as 90 feet thick. Changes in the strike and dip of the foliation in the wallrocks suggest that a major east-northeastward-trending syncline crosses the tunnel about 500 feet from the portal; other smaller folds also are present in the mine.

The first important vein intersected in the tunnel is the Virginia(?) vein, which is developed by a short drift that extends northwest from the crosscut (fig. 55 ). The vein strikes N. $42^{\circ}-52^{\circ} \mathrm{W}$, averaging about N. $48^{\circ} \mathrm{W}$., and dips $70^{\circ}-75^{\circ} \mathrm{NE}$. A vein that strikes about $\mathrm{N} .48^{\circ} \mathrm{W}$. and dips $85^{\circ} \mathrm{NE}$. is cut 10 feet nearer the tunnel portal. The movement on the Virginia (?) vein apparently is small; there is an apparent left lateral movement of about 3 feet.

The Virginia(?) vein is composed mainly of quartz and pyrite, but also contains some galena, sphalerite, and chalcopyrite. Unidentified uraniferous material is found in the Virginia (?) vein closely associated with a layer of garnetiferous lime silicate gneiss and adjacent to irregular bodies of garnetiferous lime silicate gneiss in pegmatite. The vein 10 feet northeast of the Virginia (?) vein contains 3 inches of chalcopyrite and pyrite in a quartz and carbonate gangue. A chip sample of this vein assayed 0.12 ounce of gold per ton, 3.74 ounces of silver per ton, and 7.13 percent copper.

Vein 4 strikes generally N. $57^{\circ} \mathrm{W}$. and dips $50^{\circ}-77^{\circ}$ NE. (fig. 55). The apparent strike-slip movement along the vein ranges from 20 to 32 feet, the northeast side having moved relatively northwest.

The ore minerals observed in vein 4 , in approximate increasing order of abundance, are pyrite, chalcopyrite, tennantite, galena, and sphalerite. Black soft sooty pitchblende is found over a strike length of about 200 feet, commonly on the footwall and (or) hanging wall of the vein. Proustite forms thin fracture coatings in several places in the winze 125 feet east of the crosscut tunnel. Proustite, a soft gray mineral tentatively identified as argentite, and secondary chalcopyrite were observed on a fracture that cut massive galena-sphaleritechalcopyrite ore on the east wall of the raise, 28 feet above the level of the tracks. Commonly the vein consists of highly sheared and silicified wallrock that contains local pyrite, chalcopyrite, and tennantite. Late carbonate veins, as much as several inches thick, fill fractures that are subparallel to the main fracture. Galena and sphalerite were most commonly observed as fragments in the late carbonate gangue. The paragenesis of the vein minerals is pyrite and quartz, sphalerite, chalcopyrite, tennantite, galena and sphalerite, and carbonate.
The Golconda vein is exposed along a drift length of only about 140 feet, beyond which it is caved. The vein is sparsely mineralized where accessible. The main Golconda ore shoot, according to Bastin and Hill (1917, p. 316), was west of the crosscut tunnel and extended about 250 feet along the tunnel level. The ore consisted of pyrite, chalcopyrite, some tennantite, galena, and sphalerite.

The pitchblende in the Golconda mine is the sooty variety; it is mostly along vein 4 (fig. 55) for a horizontal distance of 300 feet and down the dip at least 80 feet (fig. 56). It occurs both along the margins of the vein and in small fractures or splits from the main vein. The pitchblende in the fractures seems to be late in the paragenetic sequence. The level on which it is exposed is about 100 feet above the level of Fall River and probably was not far from the level of the water table. The depth below the surface is about 700 feet. All the pitchblende in the mine is found in one rock type, a garnetiferous lime silicate gneiss, which is inferred to have controlled the deposition of the pitchblende.

The sooty pitchblende contains variable amounts of uranium. Grab samples of the uraniferous material vary widely in uranium content but commonly contain more than 0.2 percent uranium. Samples that are virtually in equilibrium commonly are high in uranium; samples far out of equilibrium have a deficiency in uranium. Although the sooty pitchblende-bearing material exceeds ore grade over widths of as much as 1 foot, there does not seem to be any practicable way to mine or mill the material. Blasting scatters much of the sooty pitchblende along the drift beyond easy recovery, and the miners report that sooty pitchblende forms slimes on a Wilfley table.

The Mary mine is on the west side of Fall River, about 2 miles above the mouth. The workings consist of a 1,200 -foot westward-trending adit, whose portal is at an altitude of 8,200 feet (fig. 54). Formerly the adit was known as the Phillips tunnel (Bastin and Hill, 1917, p. 313). The mine has not been worked for many years; it has no recorded production.

In 1953 pitchblende was found on the dump of the mine, and some rehabilitation work, financed largely by the U.S. Atomic Energy Commission, was done to evaluate the deposit. During this work the mine was mapped by the U.S. Atomic Energy Commission, and the following description is based largely on data furnished by that agency.

The portal is in hornblende granodiorite porphyry of Tertiary age, and this rock forms the walls for 865 feet (fig. 54). From 865 to 985 feet the wallrock is Precambrian biotite gneiss, and from 985 feet to the 


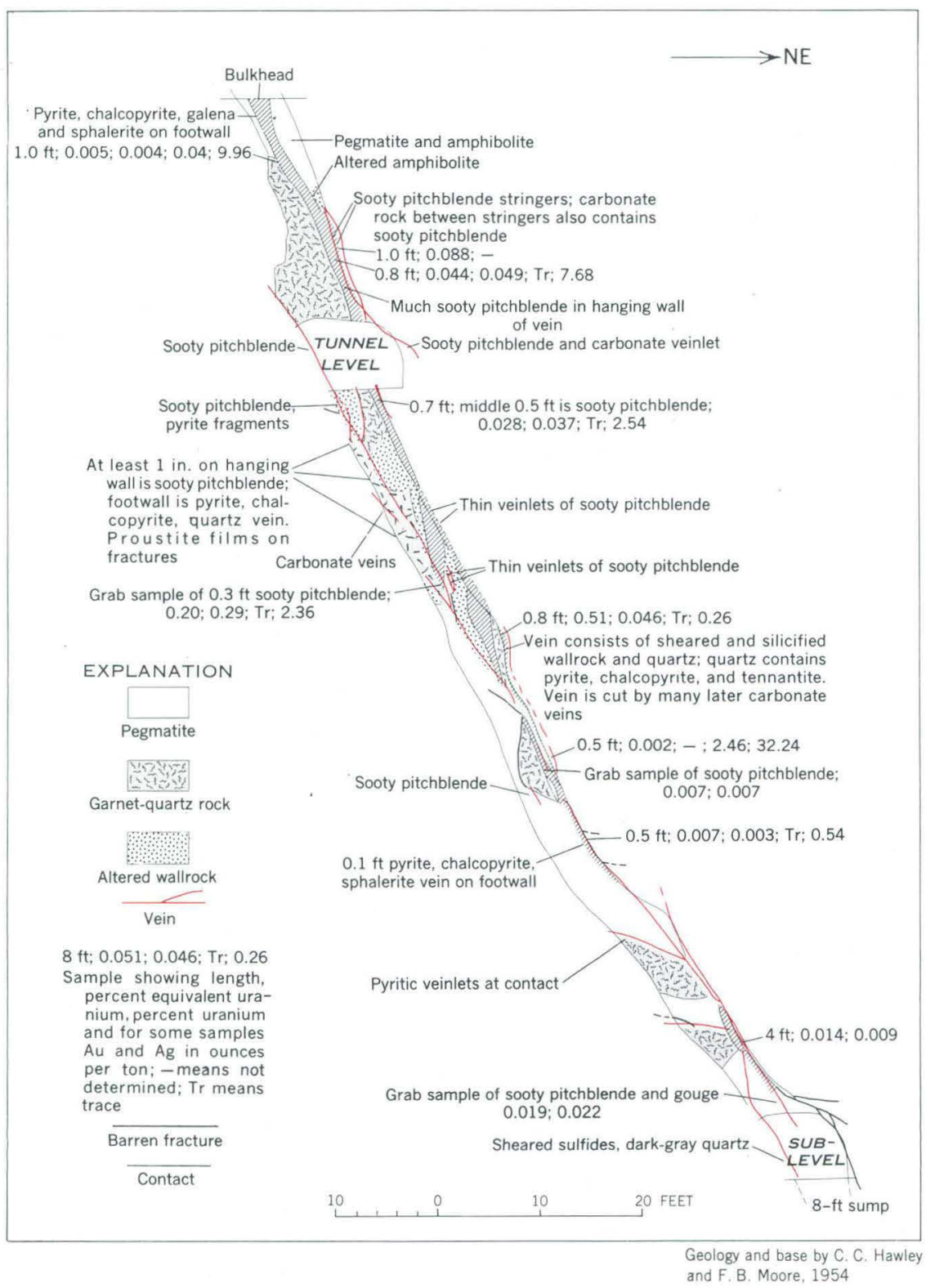

Figure 56.-Geologie section of vein 4, in the winze shown in figure 55, Goleonda tunnel, Fall River area.

face the wallrock is mainly garnetiferous lime silicate gneiss. The lime silicate gneiss is the wallrock of the uranium-bearing vein.

Three principal veins, designated as veins 1,2 , and 3 , and many minor mineralized fractures are present in the mine (fig. 54). Vein 1, cut at 405 feet, strikes N. $77^{\circ} \mathrm{W}$. and dips $65^{\circ} \mathrm{NE}$. It consists of 6 to 12 inches of quartz, pyrite, and gouge; 1 small stope was driven on the vein. Vein 2 is cut at 530 feet, and it was followed by the drift for 510 feet. The vein strikes N. $65^{\circ} \mathrm{W}$., dips $80^{\circ}$ NE. to $90^{\circ}$, and consists of 6 to 12 inches of quartz, gouge, and sparse pyrite. It was stoped locally. Vein 3, cut at 1,040 feet and drifted for a distance of
160 feet (fig. 57), strikes N. $62^{\circ}$ E. and dips $65^{\circ}$ NW.; it is parallel to and in the hanging wall of a 1 - to 2 -foot barren (?) breccia zone. Near the face at the southwest end of the drift, many small fractures that strike to the west branch into the hanging wall. At the face, the vein joins a west-northwestward-striking vein. Similar to the other veins, vein 3 consists dominantly of pyrite and quartz; locally it carries pitchblende and sparse yellow-green secondary uranium minerals.

Pitchblende occurs at three places along vein 3. Thirty feet from the face, hard botryoidal pitchblende and sparse secondary uranium minerals occur in thin closely spaced, westward-striking fractures that branch from 


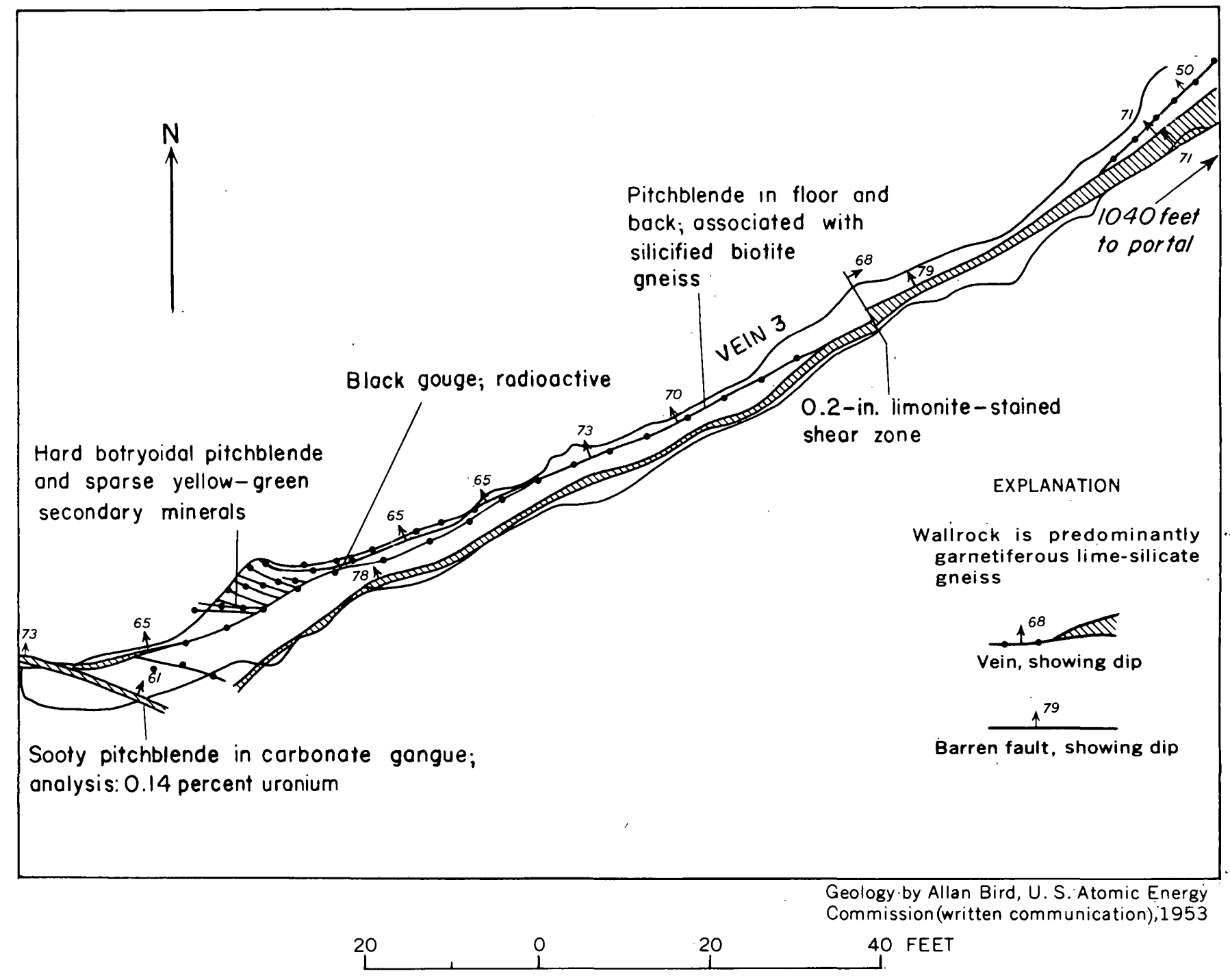

Figure 57.-Geologic map of part of the Mary mine, showing uranium occurrences along vein 3, Fall River area.

the vein into the hanging wall. The veinlets are in garnetiferous lime silicate wallrocks. Sooty pitchblende, associated with a carbonate, is present in the westward-trending vein, near the face. About 90 feet from the face, pitchblende occurs on the footwall side of vein 3 ; the size of the occurrence is not known.

A polished surface of radioactive vein material from the Mary mine shows that the pitchblende in the specimen is soft and apparently structureless. It is in tiny fractures associated with quartz, and like the sooty variety at the Golconda mine, is late in the paragenetic sequence. The other metallic minerals associated with the pitchblende, in order of their formation, are pyrite, sphalerite, tennantite, galena, and chalcopyrite. The pyrite is intensely shattered and brecciated, and it is cut by the later sulfide minerals. Tennantite is abundant in the specimen studied.

\section{LAWSON AREA}

Uranium occurs sparsely at four mines south of Lawson (pl. 3); 8 tons of high-grade pitchblende ore that contained 11,520 pounds of $\mathrm{U}_{3} \mathrm{O}_{8}$ was shipped from the Jo Reynolds mine in 1919 (table 1). The occurrences at the Bellevue-Hudson and Jo Reynolds mines and at the Robineau prospect are described briefly below.

\section{BELLEVUE-HUDSON MINE}

The Bellevue-Hudson mine is on the south side of Clear Creek, about 1 mile west of Lawson. The workings consist of three adits driven south and a shaft that primarily develops the Bellevue vein. The mine has yielded a moderate amount of ore, valued mostly for its silver content. Pitchblende is present in the Bellevue vein in the lower adit, the Bellevue-Rochester tunnel, but no uranium ore has been shipped. 
The Bellevue vein, intersected in the BellevueRochester tunnel at 972 feet, strikes N. $55^{\circ}$ E. and dips $70^{\circ}-80^{\circ} \mathrm{NW}$. It is a galena-sphalerite vein that consists of several inches to 4 feet of sheared and slightly brecciated wallrock with small quantities of vein filling-quartz, pyrite, carbonate minerals, galena, sphalerite, and locally pitchblende. In the west drift on the vein, pitchblende occurs in a small stringer along the footwall of the vein for 7 feet.

Two veins that parallel the Bellevue vein and which may be splits from it are cut in the tunnel at 960 and 1,000 feet. These two veins were drifted for short distances and contain as much as 2 inches of galena-rich ore.

\section{JO REYNOLDS MINE}

The . To Reynolds mine, on Columbian Mountain south of Inwson, has been one of the most valuable properties in the Lawson-Dumont-Fall River district. It has produced silver-lead-zinc ore valued at more than $\$ 1,500,000$ as well as small quantities of high-grade pitchblende ore (Harrison and Leonard, 1952).

The mine workings are extensive and consist of a surface stope above the Daily tunnel, drifts and large stopes on 10 levels, the Elida tunnel which forms the 11th level, and a sublevel below the Elida tunnel (fig. 58). In 1954, only the Elida tunnel was accessible (fig. 59).

The wallrocks exposed in the Elida tunnel level are dominantly Precambrian biotite gneisses, granite gneiss and pegmatite, quartz diorite, and biotite-muscovite granite; these rocks are cut by a dike of quartz bostonite porphyry and a dike of biotite-quartz latite. A detailed geologic map of the surface in the mine area is given in the report by Harrison and Leonard (1952, pl. 1). The older Precambrian rocks-interlayered biotite gneisses and granite gneiss and pegmatite-are folded into broad structures that plunge gently northeast; minor folds occur on the limbs of these folds. The younger intrusive rocks-quartz diorite and biotitemuscovite granite-occur as generally discordant bodies that cut the older, well-foliated gneisses.

The principal vein developed by the mine, the Jo Reynolds No. 2 vein, is exposed at the surface for a strike length of nearly 1,800 feet. It strikes on the average $\mathrm{N} .65^{\circ} \mathrm{E}$. and dips $60^{\circ}-85^{\circ} \mathrm{NW}$. Other minor veins, the Jo Reynolds No. 3 and Jo Reynolds No. 1, are southeast of, and virtually parallel to, the Jo Reynolds No. 2

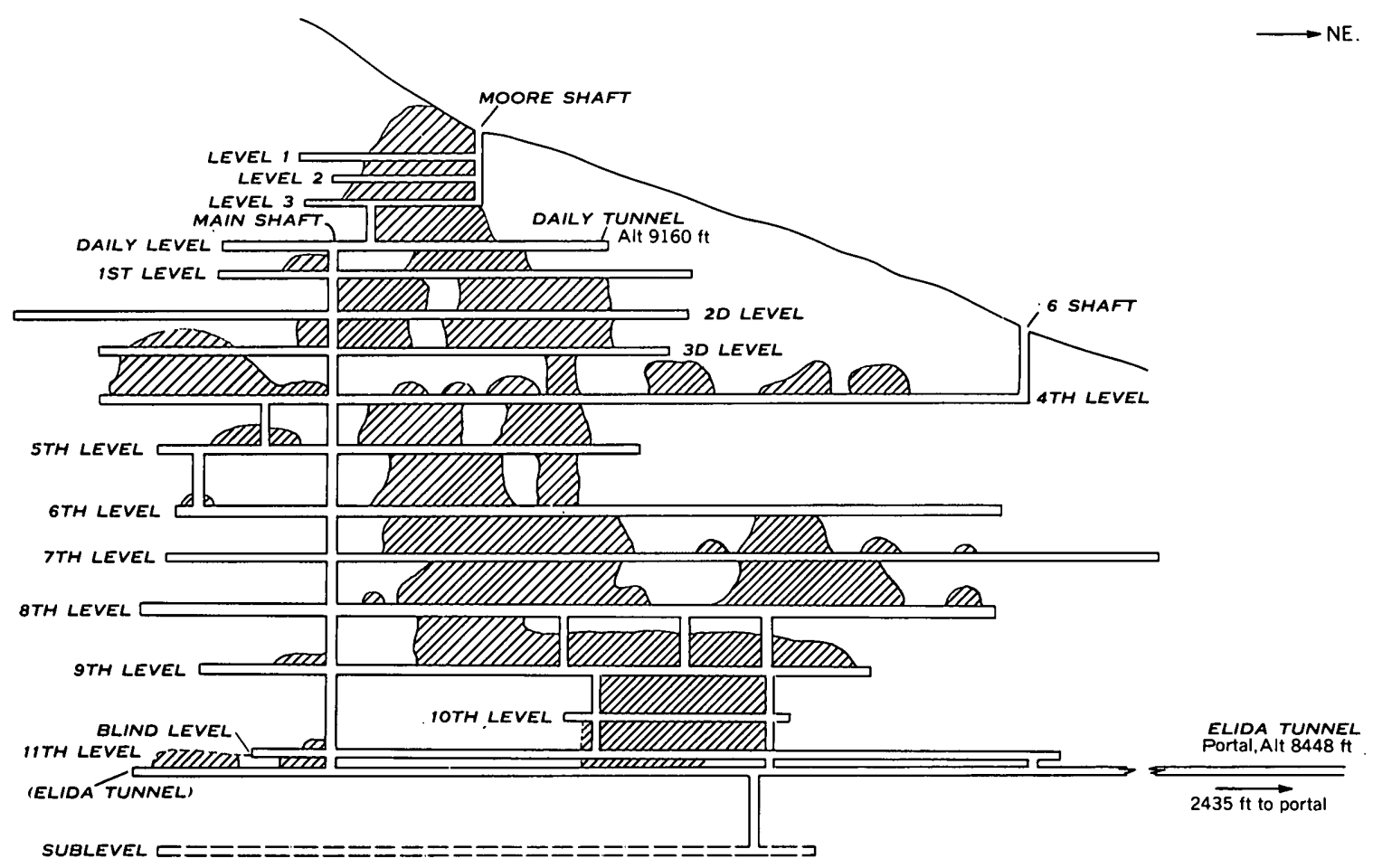

300 300 FEET

Modified from Harrison and Leonard 1952

DATUM IS MEAN SEA LEVEL 


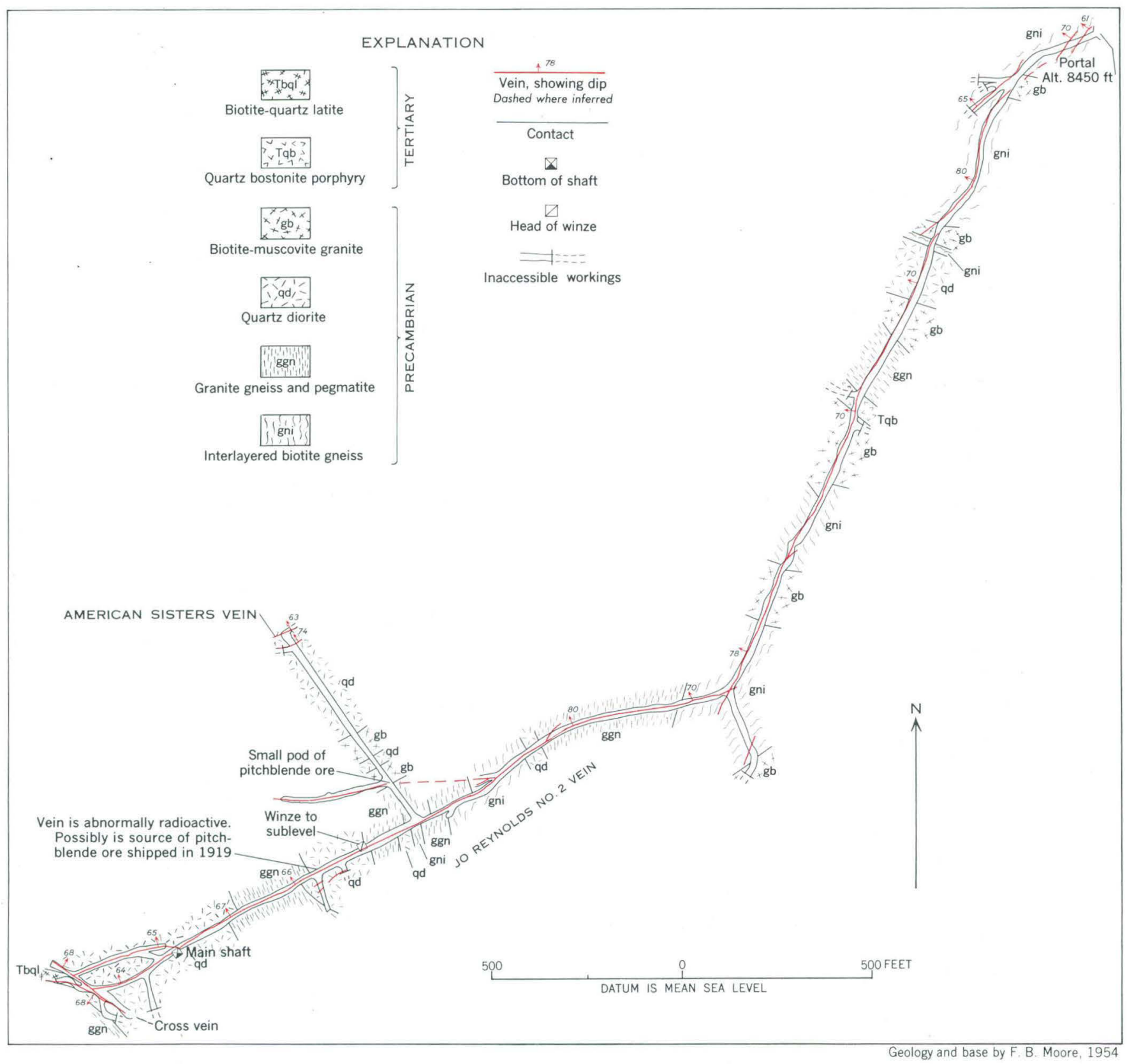

Frgure 59.-Geologic map of the Elida tunnel level, Jo Reynolds mine, Lawson-Dumont-Fall River district.

vein (Harrison and Leonard, 1952, pl. 1). The American Sisters vein is cut on the Elida tunnel level in a crosscut 600 feet northwest of the Jo Reynolds No. 2 vein (fig. $59)$; a northwestward-trending vein, called the Cross vein by the miners, also is developed on the tunnel level. The Jo Reynolds No. 2 vein seems to terminate at the Cross vein. The No. 2 vein intersects a nearly barren north-northeastward-trending vein about 1,500 feet from the portal of the Elida tunnel.

The mineralogy of each vein is closely similar. Galena, sphalerite, chalcopyrite, tetrahedrite-tennantite, and pyrite occur in a gangue of quartz, a carbonate mineral (siderite?), and gouge. Polybasite, pearceite, proustite, argentite, and native silver are present locally. The ore shoots consist dominantly of galena, sphalerite, and silver-bearing minerals.

The Jo Reynolds No. 2 vein, which has been the principal source of ore in the mine, has the shape of a flat cymoid curve in the map view. Associated fractures and shingle structures in outcrops and the offset of rock units (fig. 59) indicate that the southeast block has moved up and to the southwest relative 
to the northwest block; the apparent horizontal displacement is as much as 30 feet.

The principal ore shoots in the Jo Reynolds No. 2 vein plunge about $60^{\circ} \mathrm{N}$. $17^{\circ} \mathrm{E}$. (fig. 58). On the Elida tunnel level, ore shoots also occur in the Jo Reynolds and Cross veins near the junction of the two veins. Harrison and Leonard $(1952$, p. 8$)$ infer that the main ore shoots may be related to deflections in strike (and perhaps also dip) along the curved vein fissure or to intersection of the fault with a transverse set of joints(?).

Nine occurrences of uranium in the Jo Reynolds mine are reported by Harrison and Leonard (1952, p. 7). The reported occurrences are listed below:

1. A pocket of pitchblende on the 100 level, which may be either level 3 or level 4 of figure 58 .

2. Abeel crosscut to the No. 4 lode, and 100 and 200 levels from the Herrick shaft. These places are not further identifiable.

3. "Quite a large pocket" of uranium ore encountered in 1886 on the second or third level (Georgetown "Courier," Feb. 28, 1914).

4. Pitchblende high in radium from an 18 -inch vein whose location in the mine was not specified ("Denver Post," Nov. 10, 1914 ; "Rocky Mountain News," Nov. 11, 1914).

5. Tunnel level (Elida?), near the bottom of the old shaft, about 1,000 feet below the surface (Bastin and Fill, 1917, p. 124).

6. Sooty pitchblende(?), Elida tunnel, 100-150 feet southwest of the main shaft (R. U. King, written communication, 1951).

7. A 76-foot raise more than ' 3 feet wide in 1 to 3 percent ore; the raise was made from the tunnel (Elida?) level (Georgetown "Courier," Jan. 12,1916).

8. Eight tons of pitchblende whose location is unknown but inferred to have been in the lowest workings of the Jo Reynolds mine (R. U. King, written communication, 1951).

9. Torbernite reported by G. B. Guillotte (written communication, 1944).

During mapping of the Elida tunnel level in 1954, pitchblende or abnormal radioactivity was noted at two places on the level (fig. 59). A small pod of pitchblende-bearing material whose exact size is not known was found along the vein intersected in the drift that extends west from the American Sisters crosscut. The pitchblende is in small fractures adjacent to the main sulfide vein. As shown in figure 13, the mineral itypically forms irregular veinlets or small colloform grains. The pitchblende is earlier paragenetically than the base-metal sulfide minerals. High abnormal radioactivity occurs at the shallow winze about 100 feet west of the main shaft (fig. 59). Possibly this was the source of the pitchblende ore that was shipped in 1919.

To judge from the occurrences on the Elida tunnel level and from the reported occurrences described above, the pitchblende occurs as small lenses widely distributed along the Jo Reynolds No. 2 vein; significant quantities of pitchblende are probably not present in the mine.

\section{ROBINEAU (PEABODY) PROSPECT}

The Robineau prospect shaft is on the ridge at the southwest margin of the Lawson-Dumont-Fall River area, at an altitude of 10,570 feet. The shaft is reported to be 40 feet deep, but it was accessible to a depth of only 20 feet in 1954.

The Peabody (?) vein, which is explored by the shaft, strikes about $\mathrm{N}$. $75^{\circ} \mathrm{E}$. and dips $65^{\circ} \mathrm{NW}$. It cuts biotite-muscovite granite. The vein is as much as 1 foot wide, and it consists at the surface of chalcedonic quartz, hydrous iron oxide, torbernite, and dumontite. Some sooty pitchblende is reported from the shaft (Marvin Chase, written communication, 1954). The torbernite forms thin coatings along fractures; the dumontite occurs in $1 / 4^{-}$to $1 / 2$-inch layers along the vein.

The vein, where exposed in opencuts at the surface, is radioactive for several tens of feet, and selected samples contain more than 1 percent uranium. The grade and extent of the uranium showings are sufficient to warrant further exploration.

\section{OTHER MINES ALBRO MINE}

The Albro mine, on Albro Hill northeast of Dumont, develops the Albro vein, a pyritic vein that contains some sphalerite, galena, and copper minerals. A large amount of ore, valued largely for gold, has been taken from the mine.

Two occurrences of abnormal radioactivity, which probably are not economically important, have been found in the mine. On the first level, east of the main shaft, a 30 -foot zone gives radioactivity as much as 2 $\mathrm{mr}$ per $\mathrm{hr}$; on the third level and in pillars in the stope above the level, the vein is radioactive along a length of at least 50 feet, the maximum radioactivity being 0.2 $\mathrm{mr}$ per hr.

\section{GOLDEN CALF MINE}

The Golden Calf mine is in Fox Gulch, half a mile northeast of Dumont, at an altitude of 8,200 feet. The mine is developed by a 300 -foot drift, a winze to a lower level 73 feet down the vein dip, and a 100-foot drift on the lower level (fig. 60). The recorded production from the mine for 1934, 1937, 1940, and 1942 is 245 tons of ore containing 98 troy ounces of gold, 358 ounces of 


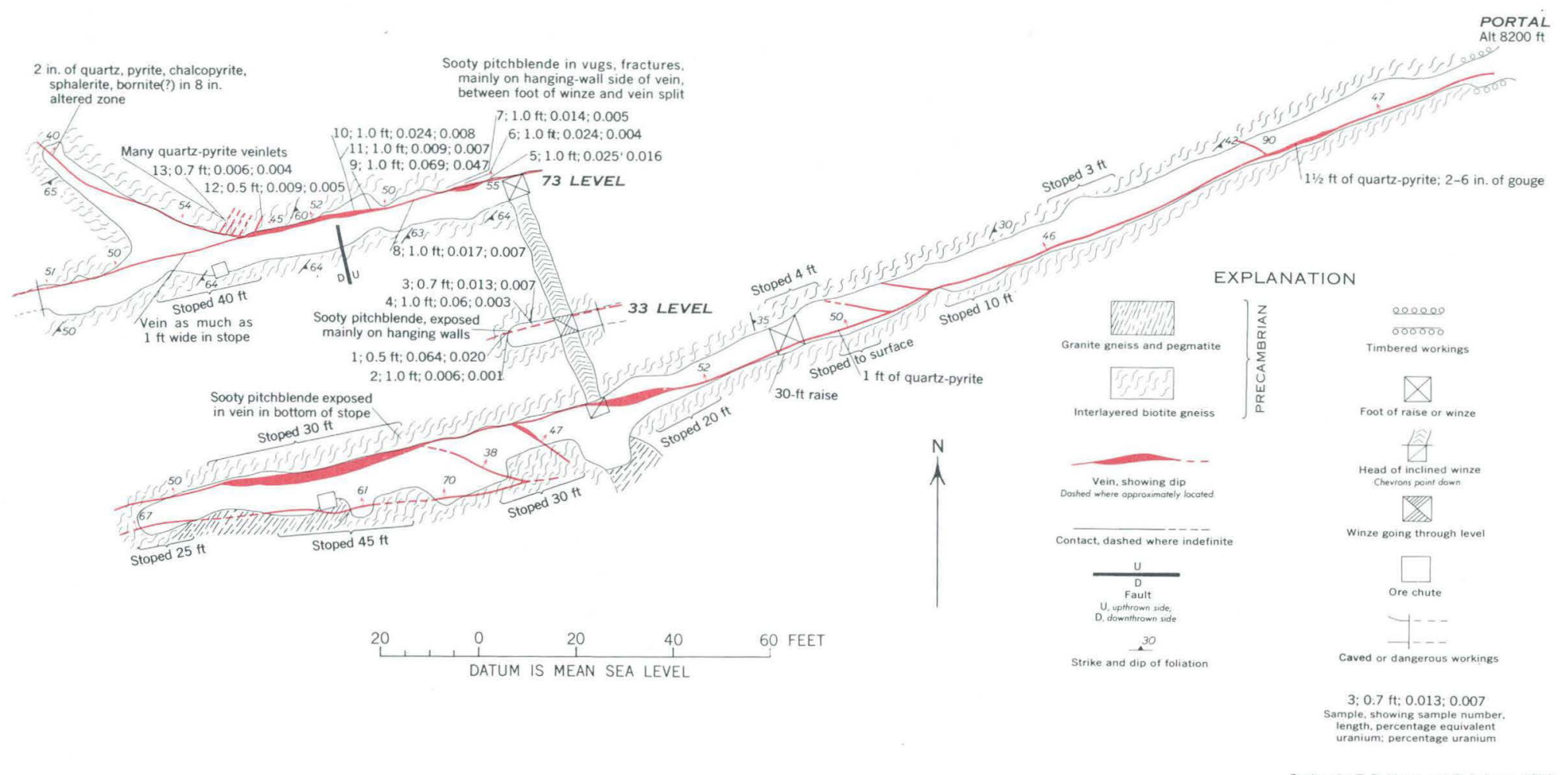

FIGURE 60.-Geologic map of the Golden Calf mine, Lawson-Dumont-Fall River district. 
silver, 438 pounds of copper, 812 pounds of lead, and 1,116 pounds of zinc. ${ }^{18}$.

The wallrock in the mine is interlayered biotite gneiss, granite gneiss, and pegmatite (fig. 60). The foliation of the country rock strikes northeast and dips southeast at an average of about $60^{\circ}$. It is cut at an angle of about $35^{\circ}$ by the vein.

The Golden Calf vein strikes N. $68^{\circ}$ E. for 180 feet from the portal and N. $78^{\circ} \mathrm{E}$. for the next 120 feet; dips range from $46^{\circ}$ to $55^{\circ} \mathrm{NW}$ : and average about $50^{\circ}$. Possibly the vein is a branch from the Albro vein. Small branch veins that strike N. $70^{\circ} \mathrm{W}$. split from the main vein 200 to 250 feet from the portal. The Golden Calf vein ranges from 3 inches to 3 feet in thickness, and where exposed, contains only one sizable ore body. Vein minerals in apparent order of deposition from oldest to youngest are quartz, white quartz and pyrite, gray quartz and fine-grained pyrite, chalcopyrite, sphalerite, galena, sooty pitchblende, and carbonate.

The main ore body in the mine was cut from 240 to 280 feet from the portal. It extends above the level and persists downdip to the lower level. The vein where stoped is nearly 3 feet wide but most of the ore minerals are on the hanging wall.

Sooty pitchblende occurs along the hanging wall of the vein within and east of the main ore shoot. The radioactive zone averages nearly 1 foot in thickness and extends for nearly 50 feet along the drift on the lower level. A total of 18 samples representing an average vein width of 0.8 foot contained an average of 0.012 percent uranium. These samples were taken from the lower level, from the 33 sublevel, and from the underhand stope below the adit level (fig. 60). A sample collected from the ore bin, which is reported (Ben Stanhope, oral communication 1952) to have come from the stope on the lower level, contained 0.15 percent uranium. The stope was inaccessible in 1952.

The uranium ore shoot at the Golden Calf mine as now exposed is not of commercial grade. The presence of considerably higher uranium values in ore from the ore bin, however, shows that at least parts of the ore shoot contain significant amounts of uranium.

\section{IDAHO SPRINGS DISTRICT}

By R. H. MOENCH

Several uranium occurrences of geologic interest are present in the Idaho Springs district, but none has been extensively explored or developed and to date (1955) there has been no uranium production from the district. The deposits are widely distributed, and so far as ${ }^{18}$ Complled from U.S. Bureau of Mines records. Published by per-
mission. known are small. Most occurrences consist of secondary uranium minerals, probably alteration products of primary pitchblende, but pitchblende is known to occur at a few localities. A mineral tentatively identified as thucholite occurs along one vein.

As stated previously (p. 10), uraninite-bearing biotite granite pegmatite bodies of Precambrian age are abundant in a narrow belt that extends northeast from the mouth of Trail Creek to beyond Virginia Canyon. The pegmatites in Virginia Canyon have been mined as a source of uranium, but although some uraninite concentrates and hand-sorted uranophane-bearing pegmatites were shipped, the operation was not profitable.

\section{ALMA LINCOLN MINE}

The Alma Lincoln mine, on the south side of Clear Creek, 1 mile west of Idaho Springs, consists of more than 10,000 linear feet of underground workings on 2 important veins, the Lincoln and the Elliot Barber, and 3 lesser veins, the South Lincoln, Josephine, and Donna Juanita. All the veins are pyrite veins that contain galena, sphalerite, and copper minerals. The combined production from the mines on these veins between 1902 and 1950 is 269,983 tons of ore rontaining 50,874 troy ounces of gold, 236,935 ounces of silver, 493,177 pounds of copper, $2,462,804$ pounds of lead, and 178,859 pounds of zinc. ${ }^{19}$

Abnormal radioactivity resulting from pitchblende(?) secondary uranium minerals, and thucholite (?) is present at several places on levels 2 and 3 of the mine. Although the occurrences are of geologic interest, none seems to be of commercial value.

Forty feet from the southwest face of level 2, the Lincoln vein is abnormally radioactive over a length of 5 feet; analysis of a grab sample gave 0.089 percent equivalent uranium and 0.063 percent uranium. The radioactivity is due to betazippeite ${ }^{20}$ which occurs in fractures along the hanging wall and footwall and in fractures that cut across the Lincoln vein. Scattered small rosettes of schroeckingerite coat the mine walls 1 foot or more from the vein. Probably both of the colored uranium minerals formed after development of the mine and were derived from pitchblende.

At one place on level 2 and at several places on level 2 , radioactive fissures occur along the footwall and locally cut the main vein. The fissures consist of finely ground vein material and altered wallrock. At places slip surfaces in the gouge are coated by zippeite. One specimen of a radioactive gouge-filled fracture contains

${ }^{10}$ Compiled from U.S. Bureau of Mines records. Published by permission.

${ }^{20}$ Identifled by $\mathbf{X}$-ray methods by $\mathbf{A}$. J. Gude 3d and W. F. Outerbridge, U.S. Geological Survey. 
a few grains of a dull black material that has a conchoidal fracture. The material is highly radioactive, has a specific gravity of 1.91 to 1.93 , and gives a clear $\mathrm{X}$-ray powder pattern similar to sphalerite; it is tentatively identied as thucholite.

\section{DIAMOND JOE TUNNEL}

\section{BJ A. A. DRAKE, JR.}

The Diamond Joe tumnel is in upper Virginia Canyon about 1,360 feet $\mathrm{N}$. $37^{\circ} \mathrm{W}$. from the Two Brothers tunnel. In the spring of 1953 , a lessee found that parts of the tunnel were abnormally radioactive. Marvin Chase of the U. S. Atomic Energy Commission examined the mine in the same year and found that the source of the abnormal radioactivity was patches of a fluorescent secondary uranium mineral, probably zippeite, on the drift walls.

The Diamond Joe tunnel is 1,285 feet long and has a general westerly bearing. The tunnel connects to the Specie Payment mine through a raise, and to the Two Brothers tunnel through an underhand stope. The Specie Payment workings were accessible in 1953, but the workings of the Two Brothers tunnel directly below the Diamond Joe were not open.

The wallrock of the tunnel is microcline-bearing gneiss, which contains small bodies of granite pegmatite. The microcline-bearing gneiss is intruded by two quartz bostonite porphyry dikes, which are part of the Pewabic Mountain dike swarm. The first of the two dikes is cut by the tunnel about 495 feet from the portal. This dike strikes N. $48^{\circ}$ E., dips $75^{\circ} \mathrm{SE}$, and is $\mathbf{1 0}$ feet thick. The second dike, intersected about 695 feet from the portal, strikes N. $68^{\circ}$ E., dips $75^{\circ}$ SE., and is about 23 feet thick.

The Diamond Joe tunnel is driven on the Specie Payment vein, which has a westward to northwestward strike. The vein is highly variable in dip, ranging from $15^{\circ}-75^{\circ} \mathrm{N}$. The width of the vein ranges from 6 to about 24 inches. The ore minerals are galena, sphalerite, chalcopyrite, tennantite, and pyrite. The vein has been filled by two generations of minerals. In general, a filling of quartz and pyrite has been fractured and brecciated and the resulting fissures filled by basemetal sulfides and sulfosalts to form a composite vein.

Patches of an orange-yellow, light-green fluorescent uranium mineral form efflorescent coatings on the vein and the vein walls at places between 495 and 1,083 feet from the portal. Microscopic study and an X-ray determination by W. F. Outerbridge of the Geological Survey have confirmed that the mineral is zippeite. The source of the uranium is not definitely known, but because of its close spatial association with quartz bostonite, it is believed that the uranium probably, was leached from the dikes. A radiometric examination of all the accessible Diamond Joe and Specie Payment workings failed to disclose other abnormally radioactive rock or vein material.

Commercial quantities of zippeite are not present in the mine. Table 28 presents assays of five grab samples taken at different locations. These samples represent the best material available at the given locality and were collected by scraping the surfaces with a knife blade. Only samples 4 and 5 approach commercial value.

Table 28.-Analyses of zippeite-bearing material, Diamond Joe tunnel

[Analyses by U.S. Geol. Survey; analysts, S. P. Furman and R. F. Dufour]

\begin{tabular}{|c|c|c|c|}
\hline Sample & $\begin{array}{c}\text { Distance } \\
\text { from portal } \\
\text { (feet) }\end{array}$ & $\begin{array}{l}\text { Equivalent } \\
\text { uranium } \\
\text { (percent) }\end{array}$ & $\begin{array}{l}\text { Uranium } \\
\text { (percent) }\end{array}$ \\
\hline $\begin{array}{l}\text { DJ-1 } \\
\text { DJ-2 } \\
\text { DJ-3 } \\
\text { DJ-4 } \\
\text { DJ-5 }\end{array}$ & $\begin{array}{r}741 \\
778 \\
984 \\
969 \\
1,010\end{array}$ & $\begin{array}{l}0.016 \\
.042 \\
.017 \\
.140 \\
.089\end{array}$ & $\begin{array}{l}0.012 \\
.020 \\
.013 \\
.280 \\
.190\end{array}$ \\
\hline
\end{tabular}

JENNIE IIND NO. 1 TUNNEL

The portal of the Jennie Lind No. 1 tunnel is at an altitude of 8,630 feet on Bellevue Mountain, about halfway between the crest and Idaho Springs (pl. 3). The tumnel bears $\mathrm{N} .17^{\circ} \mathrm{E}$. and is caved (in 1954) at 280 feet; it follows a vein that strikes N. $14^{\circ}-20^{\circ}$ E. and dips $60^{\circ} \mathrm{W}$. to $90^{\circ}$. The vein consists dominantly of quartz, pyrite, and gouge, but contains some tennantite, chalcopyrite, and galena.

Abnormal radioactivity occurs both in the Jennie Lind vein and locally in altered wallrocks adjacent to the vein. At places along the drift the radioactivity of the vein is as much as five times that of background; the uranium-bearing mineral is not known. A sample from an apparently unoxidized part of the vein containing abundant gouge and pyrite, taken 193 feet from the portal, contains : ${ }^{21} 0.021$ percent equivalent uranium, 0.005 percent uranium, 0.40 ounce of gold per ton, 2.07 ounces of silver per ton, 0.03 percent copper, 0.13 percent lead, and 0.26 percent zinc. Another sample consisting of gouge, gossan, and altered wall rock, taken 70 feet from the portal, contains: 0.025 percent equivalent uranium, 0.025 percent uranium, a trace of gold, 0.10 ounce of silver per ton, 0.02 percent copper, 0.11 percent lead, and 0.23 percent zinc.

The wallrocks are abnormally radioactive at two localities. The first radioactive locality, 55 to 90 feet from the portal, measures 0.1 to $0.19 \mathrm{mr}$ per hr on a survey meter; the second locality, 170 to 235 feet from the portal, measures 0.08 to $0.16 \mathrm{mr}$ per hr on the same

${ }^{21}$ Analyses by U.S. Geol. Survey. Analysts: S. P. Furman, E. C. Mallory, Jr., J. E. Wilson. 

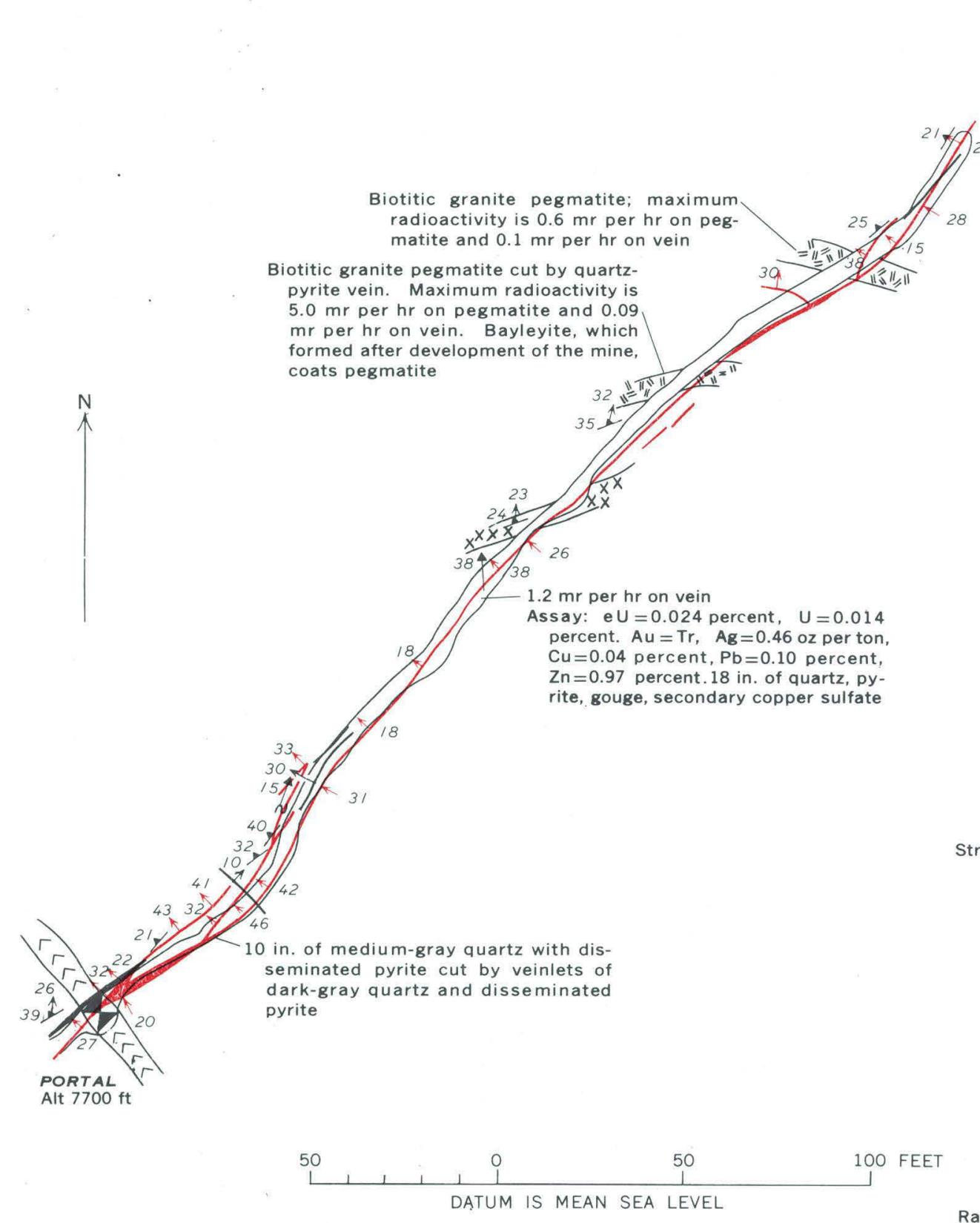

EXPLANATION
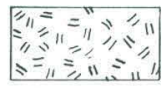

Pegmatite

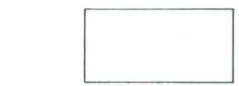

Microcline-bearing gneiss

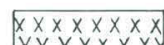

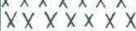

$x \times x \times x \times x$

Amphibolite

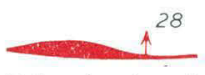

Vein, showing dip

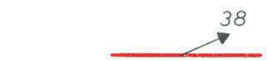

Vein, showing plunge of curvature
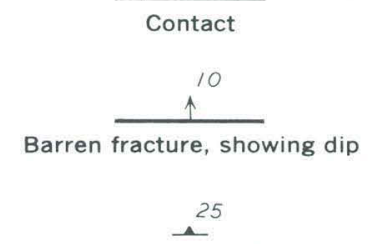

Strike and dip of foliation

$$
35^{32}
$$

Strike and dip of foliation, and plunge of

lineation

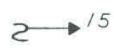

Plunge of asymmetric drag fold

Shaft going above and below level

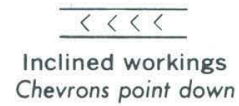

$1.2 \mathrm{mr}$ per $\mathrm{hr}$ on vein

Radioactivity, in milliroentgens per hour

Geology and base by R. H. Moench and E. W. Tooker, 1953

Figure 61.-Geologic map of the New Bedford mine, Idaho Springs district.

counter. The radioactivity is due to autunite and metatorbernite which are distributed along joints and are locally disseminated in altered biotite-quartzplagioclase gneiss and to a lesser extent in sillimanitic biotite quartz gneiss wall rocks.

\section{MAB TUNNEL}

The adit of the MAB tunnel is on the north side of Clear Creek, about 11/8 miles west of Idaho Springs. It was driven northeastward about 100 feet on a vein that strikes N. $43^{\circ} \mathrm{E}$. and dips $40^{\circ} \mathrm{N}$. The vein is abnormally radioactive from the portal for 42 feet.
Analyses ${ }^{22}$ of a grab sample from the vein indicated 0.035 percent equivalent uranium, 0.036 percent uranium, 0.20 ounce of gold per ton, 0.34 ounce of silver per ton, 0.01 percent copper, 0.07 percent lead, and 0.09 percent zinc.

\section{NEW BEDFORD TUNNEL}

The portal of the New Bedford tunnel, a drift 350 feet long that bears N. $42^{\circ}$ E. (fig. 61), is 2,000 feet east of the confluence of Clear Creek and Fall River (pl. 3).

${ }_{22}^{22}$ Analyses by U.S. Geol. Survey. Analysts: S. P. Furman, R. F. Dufour, D. L. Skinner, and E. C. Mallory, Jr. 
The adit cuts a large body of microcline-bearing gneiss, which in the mine contains a single layer of amphibolite and two narrow bodies of uraninite-bearing biotite pegmatite. The adit is on the northwest limb of a closed anticline, overturned to the southeast.

Both layers of pegmatite exposed in the mine are abnormally radioactive. The pegmatite nearest the portal (fig. 61) has a maximum radioactivity of $5 \mathrm{mr}$ per $\mathrm{hr}$; it is partly coated by bayleyite which formed after development of the mine. A chip sample across this pegmatite contains 0.037 percent equivalent uranium and 0.057 percent uranium. In sampling, care was taken to avoid the bayleyite. The second pegmatite body, which is 50 feet from the face of the adit, has a maximum radioactivity of $0.6 \mathrm{mr}$ per $\mathrm{hr}$; a chip sample across this body contained 0.017 percent equivalent uranium and 0.014 percent uranium.

The vein followed in the drift (fig. 61) is abnormally radioactive at one locality, 170 feet from the portal and 80 feet southwest of the nearest exposed pegmatite. An analysis of a chip sample taken across the vein at this point contains 0.024 percent equivalent uranium and 0.014 percent uranium. The uranium-bearing mineral that produces the radioactivity is not known.

\section{RED JACEET MINE}

The Red Jacket claim is in Virginia Canyon, 1,900 feet south of the Two Brothers tunnel. In 1954, pitchblende was discovered by the operator in a small adit that is at an altitude of 8,420 foet on the east side of the canyon. The adit, 25 feet long, is 40 feet northwest of the Patten adit. The pitchblende showing has not been developed and little is known of the deposit.

The vein, as exposed in the adit, strikes N. $50^{\circ} \mathrm{E}$. and is vertical. It is virtually parallel to the foliation in the Precambrian country rock-granite pegmatite and microcline-bearing gneiss. The vein consists of several subparallel quartz-pyrite veinlets; most are nearly vertical, but a few dip about $60^{\circ} \mathrm{NW}$. Pitchblende occurs as a sparse local component in one of the veinlets; at places the pitchblende is coated by torbernite, which probably formed after development of the mine.

In polished section the pitchblende is seen to be hard and lustrous and it occurs as highly irregular, delicate branching forms that are aggregated along ill-defined, irregular, $1 / 16$-inch stringers. The pitchblende is intergrown with quartz. The wallrock adjacent to the pitchblende stringers has a distinct red color. A small amount of chalcopyrite, partly altered to chalcocite, occurs in the same polished section.

\section{SHAFTER MINE}

Altered wallrock adjacent to the Shafter vein is locally radioactive in the Shafter adit, on Bellevue Mountain (pl. 3). The uranium occurrence is similar to that in the Jennie Lind No. 1 tunnel, which is 600 feet $\mathrm{S}$. $52^{\circ}$ E. from the Shafter adit.

The Shafter adit, at an altitude of 8,750 feet, is 400 feet $N$. $45^{\circ}$ E. from the Fairmount shaft, one of the large shafts on the important Shafter vein. The adit is a drift that extends 360 feet N. $45^{\circ}$ E.; it is caved beyond that point. The adit cuts granite gneiss and pegmatite that contains sparse, thin layers of interlayered biotite gneisses.

The Shafter vein, as exposed in the adit, strikes $\mathrm{N}$. $45^{\circ} \mathrm{E}$. and dips $55^{\circ}-89^{\circ} \mathrm{NW}$. It is a pyrite vein that contains copper minerals. The vein is slightly. radioactive (about twice the background count) 160 feet from the portal; adjacent to this part of the vein the wallrock-predominantly biotite-quartz-plagioclase gneiss-is radioactive, reaching a maximum of $0.2 \mathrm{mr}$ per hr, as determined by a rate meter. The radioactivity results from torbernite (or metatorbernite) that coats iron-stained joints and locally is disseminated through the altered biotite gneiss. The grade and quantity of uranium-bearing rock are not known.

\section{STANLEY MINE}

The Stanley mine, one of the largest and most productive mines in the Idaho Springs district, is on the south side of Clear. Creek about four-fifths of a mile west of Idaho Springs. Only the uranium occurrence in the mine is described in this report.

Pitchblende is present in the Stanley vein on the road level of the mine, 2,435 feet southwest of the portal. The pitchblende occurs within an abnormally radioactive 60 -foot-long segment of the vein. Chip samples across the radioactive zone at 5 -foot intervals indicated a range for most samples from 0.003 to 0.14 percent uranium; one analysis, a sample from the middle part of the zone, gave 0.32 percent equivalent uranium and 0.33 percent uranium. A raise driven on this part of the zone showed that the radioactivity extended only 10 feet above the level.

The pitchblende is hard and shiny, and it has a microcolloform texture; generally it appears to be coated by black sooty material. In some specimens the pitchblende occurs as thin, colloform coatings on pyrite; the pyrite, in turn, occurs as a colloform coating on gray quartz, galena, and cubic pyrite. Abundant yellowgreen crystals, probably a secondary uranium mineral, are perched on some of the pitchblende grains. The 


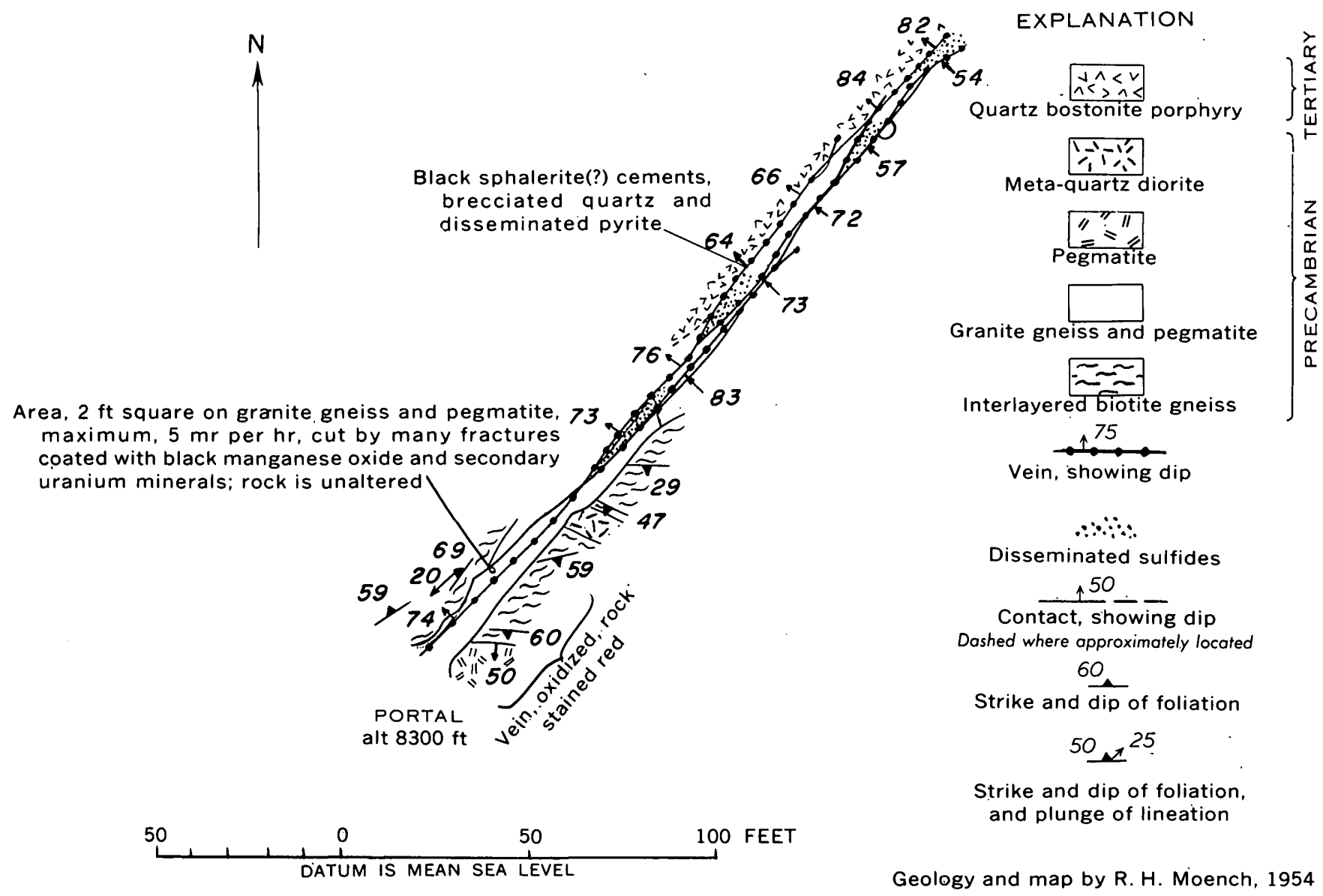

Figukb 62.-Geologic map of the Star mine, Idaho Springs district.

pitchblende, together with pyrite and colloform silica, occurs in fractures that cut all the primary sulfide and gangue minems, indicating that it is later parageneticially than the main sulfide mineralization.

\section{STAR MINE}

The Star mine is on the north side of South Spring Gulch, at an altitude of 8,300 feet. The mine (fig. 62) is a 210 -foot drift that bears N. $40^{\circ} \mathrm{E}$. No stopes are present.

Interlayered biotite gneisses, pegmatite, granite gneiss and pegmatite, and a thin layer of quartz diorite constitute the bulk of the wallrocks. An altered quartz bostonite body forms the northwest wall of the drift from a point 120 feet from the portal to the face; the dike is probably the same dike that is exposed along the road 150 feet west of the portal. The foliation of the rocks on the northwest wall strikes N. $40^{\circ}-55^{\circ}$ E. and $\operatorname{dips} 59^{\circ}$ to $69^{\circ} \mathrm{NW}$. The foliation on the southeast wall strikes N. $80^{\circ}$ E. to N. $68^{\circ}$ W., and dips $29^{\circ}$ to $60^{\circ}$ S. An asymmetric anticlinal fold axis passes north- east through the portal and the south wall of the drift 85 feet from the portal. It plunges southwest at a moderate angle.

The vein exposed in the Star mine is probably equivalent to the vein worked in the Little Mattie and Wild Rose mines to the southwest; to the northeast the vein is worked in the Bullion-King mine. Several branches diverge to the northeast and probably make up the Lafayette, Mayflower, and other veins on the south side of Clear Creek. The Star vein strikes N. $40^{\circ} \mathrm{E}$. and dips $54^{\circ}-82^{\circ} \mathrm{NW}$. At several places the vein branches. These branches diverge gradually to the northeast, as do the branches mapped on the surface. The main vein is as much as 18 inches thick, and consists of intensely sheared, silicified, and pyritized wallrock. At the vein junctions the rock is silicified and impregnated with pyrite. Base-metal sulfides occur in pods and veins that cut the original pyritic vein, and they locally heal brecciated, silicified, and pyritized wallrock. Of the basemetal sulfides, sphalerite predominates; tennantite and galena occur in minor amounts. The sphalerite con- 
tains a trace of blebby chalcopyrite. Locally along the hanging wall or footwall of the vein both the vein and the wallrock are brecciated in a zone as much as 6 inches thick. The vein is oxidized for a distance of about 40 feet from the portal.

The metal content of the vein is indicated by the assays given below, which represent selected grab samples of the vein. Sample Star-2 is from the base metal-bearing part of the vein, whereas sample Star-3 is from the pyritic part.

Assays of selected grab samples from the Star vein

[Analyses by U.S. Geol. Survey. Analysts: S. P. Furman, H. H. Lipp, James Wahlberg, Dwight Skinner, Wayne Goss, E. C. Mallory, Jr.]

\begin{tabular}{r|r|r|r|r|r}
\hline \multirow{2}{*}{ Sample } & \multicolumn{2}{|c|}{ Ounces per ton } & $\begin{array}{r}\text { Copper } \\
\text { (percent) }\end{array}$ & $\begin{array}{r}\text { Lead } \\
\text { (percent) }\end{array}$ & $\begin{array}{r}\text { Zinc } \\
\text { (percent) }\end{array}$ \\
\cline { 2 - 5 } & \multicolumn{1}{|c|}{ Gold } & \multicolumn{1}{|c|}{ Silver } & & \\
\hline Star-2.2. & $\begin{array}{r}\text { Tr } \\
1.70\end{array}$ & $\begin{array}{r}0.25 \\
.10\end{array}$ & $\begin{array}{r}7.77 \\
.05\end{array}$ & $\begin{array}{r}0.80 \\
.13\end{array}$ \\
\hline
\end{tabular}

Tr means trace

Because the structure of the vein is complex, the thickness of the altered zone is greater than normal. At one place interlayered biotite gneisses (mainly biotite-quartz-plagioclase gneiss) are silicified for about 6 inches southeast of the vein; mafic minerals (mainly biotite) are altered for an additional 6 inches, and feldspar (probably plagioclase) is altered for 1 foot making a total of 24 inches for the thickness of the altered zone. Where the vein cuts pegmatite, the pegmatite is only slightly altered.

Although the radioactivity of the vein is normalnowhere exceeding $0.06 \mathrm{mr}$ per $\mathrm{hr}$-at one locality finegrained granite gneiss and pegmatite give a highly anomalous reading. Near the floor on the north wall, 28 feet from the portal, an area 2 feet square gives a maximum radioactivity of $5 \mathrm{mr}$ per hr. The radioactive rock is apparently unaltered, but it is highly fractured. The fractures are filled with wad, a mixture of hydrous manganese oxides; pitchblende, altered to different degrees; and the secondary uranium minerals, meta-autunite, metatorbernite, and uranophane. The pitchblende is seen in a polished surface to occur in veinlets less than $1 \mathrm{~mm}$ wide with quartz and sparse pyrite. The outer surfaces of the pitchblende veinlets are spheroidal. The pitchblende is partly altered to soft sooty material. The meta-autunite occurs in small sunbursts and has a strong yellow-green fluorescence. The uranophane is very fine grained and light gray green. The adjacent rocks are strongly iron stained along fractures to a red or red-brown color, and the vein is oxidized an additional 12 feet from the portal. The nearby quartz bostonite, which is less than 1,000 feet southeast of the vein, possibly is the source for the uranium. An analysis ${ }^{23}$ of one sample of the rock gave 0.78 percent equivalent uranium and 0.72 percent uranium.

\section{SUNNYSIDE MINE}

By J. E. HARRISON and R. H. MOENCH

The Sunnyside mine, at an altitude of 8,630 feet, is near stream level on the northwest side of Trail Creek, about $13 / 4$ miles southwest from its confluence with Clear Creek. The mine (fig. 63) consists of a crosscut adit that bears N. $23^{\circ} \mathrm{W}$. for 510 feet from the portal, a drift at 430 feet from the portal, a short drift at the end of the crosscut, and two short drifts between the main drift and the face of the crosscut. Some stoping has been done in the east part of the main drift.

Production records indicate that the Sunnyside mine was worked in 1909, 1915, 1932, and from 1935 to 1941. The total recorded production is 314 tons of ore that contained 64 troy ounces of gold, 167 ounces of silver, 879 pounds of copper, 568 pounds of lead, and 2,031 pounds of zinc. ${ }^{24}$ At the time of this study (April 1955) the short drifts at and near the face of the crosscut were being prospected for uranium.

Interlayered biotite gneisses, locally migmatitic, make up most of the wallrock. Granite gneisses and pegmatite make up the walls of the main drift, and biotite-muscovite granite is exposed near the portal. With much local variation, these rocks strike mostly northeast to east, and dip at a low to moderate angle to the north. Linear structures in the Precambrian rocks bear north-northeast and north-northwest.

The main drift follows a lode that consists of several close-spaced subparallel veins. The lode strikes $\mathrm{N}$. $75^{\circ} \mathrm{E}$. to east, dips $40^{\circ}-75^{\circ} \mathrm{N}$., and is steepest where the vein strikes more nearly east. In the mine the lode follows a layer of granite gneiss and pegmatite. On the surface the vein was traced several thousand feet to the east, cutting mainly granite gneiss and pegmatite. Broken and altered wallrock along the drift is impregnated with pyrite and cut by many veins. Individual vein fissures are half an inch to 4 inches thick and consist of quartz and pyrite plus veinlets and pods of tennantite, chalcopyrite, and minor amounts of galena, sphalerite, and a carbonate mineral. Production data, however, suggest that the lode is richer in galena and sphalerite than the observed mineral content suggests.

A vein that is subparallel to the main lode is $\mathrm{ex}$ posed 70 feet northwest of the main lode, at the face of the crosscut adit. The vein is three-fourths of an

${ }^{2 a}$ Analysis by U.S. Geol. Survey. Analysts, S. P. Furman, H. H. Lipp.

${ }^{24}$ Compiled from U.S. Bureau of Mines records. Published by per- 


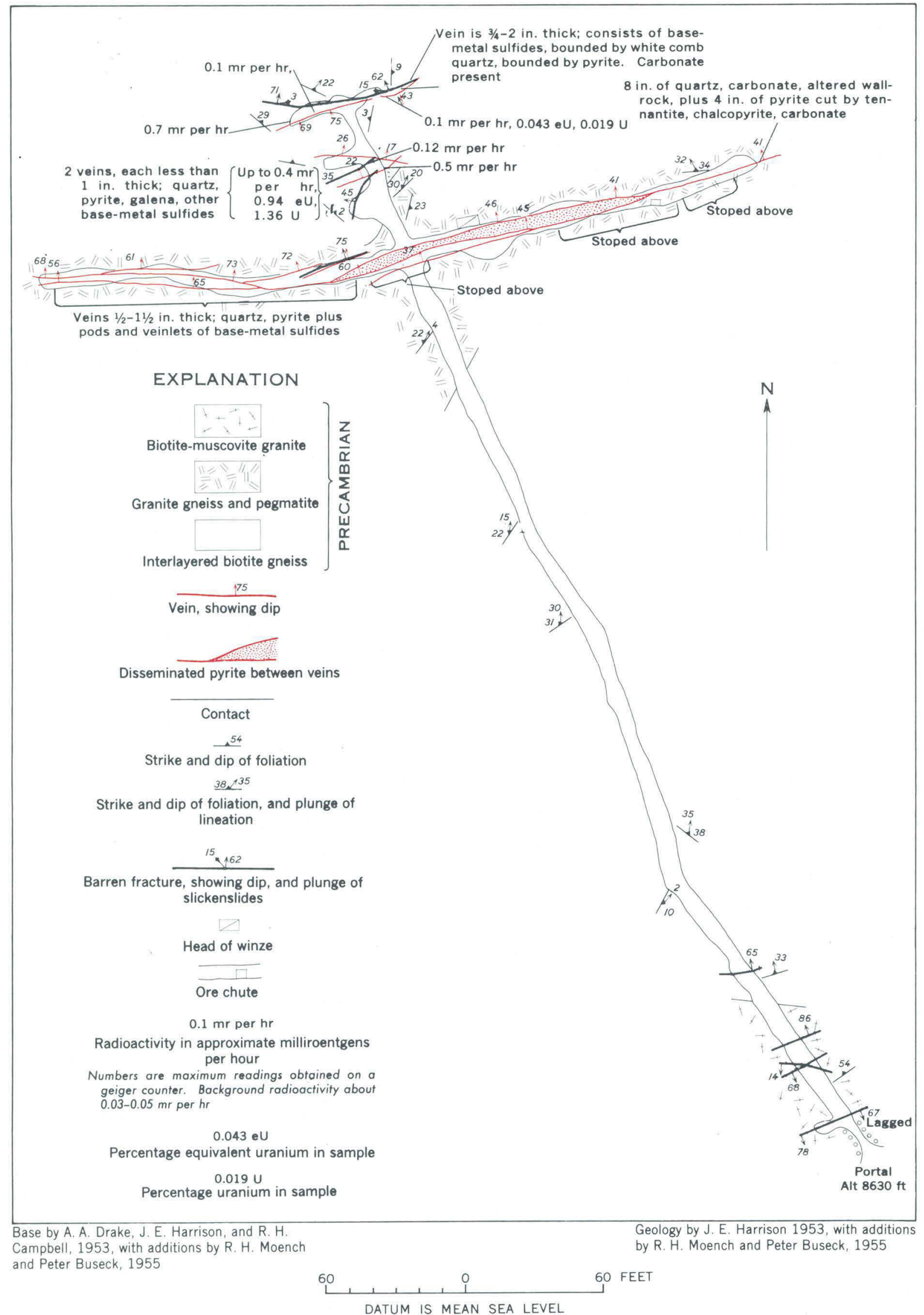

DATUM IS MEAN SEA LEVEL

Figure 63.-Geologic map of the Sunnyside mine, Idaho Springs district. 
inch to 2 inches thick and is symmetrically layered. The center of the vein is composed of base-metal sulfide minerals, predominantly sphalerite; this mineral is bounded by gray to white comb quartz, which is bounded by pyritohedral pyrite. Much of the vein is anomalously radioactive.

Two veins that strike east-northeast to east and dip $20^{\circ}-40^{\circ} \mathrm{N}$. are exposed about halfway between the main lode and the vein at the face. These flat-dipping veins are similar mineralogically to the steeper vein and lode, but are thinner, generally being less than 1 inch thick. The veins are thicker in their steeper parts. They are anomalously radioactive over much of their exposed length.

Several barren faults that contain a white claylike gouge are subparallel to the veins. These faults cut the veins at a low angle. Slickensides and displacements of the veins suggest a strike-slip movement, in which the hanging wall moved west 1 or 2 inches relative to the footwall.

A maximum of about $1.0 \mathrm{mr}$ per $\mathrm{hr}$ was obtained on the most northerly steep vein. Analyses ${ }^{25}$ of samples taken from the thin flat veins contain a maximum of 0.94 percent equivalent uranium and 1.36 percent uranium. The uranium mineral is pitchblende that occurs with pyrite along slickensided surfaces on the hanging and footwalls of the veins. Torbernite and autunite also are present locally. The gouge-filled faults that cut the uranium-bearing veins are locally slightly radioactive, and give readings of as much as $0.12 \mathrm{mr}$ per hr, which is distinctly less than the veins.

The pitchblende is hard black and shiny and is intergrown with pyrite. It is older than the base-metal sulfides. At places sooty material derived by the alteration of the hard pitchblende coats fractures in the ore and slickensided surfaces along the vein.

The pitchblende possibly is localized at the intersections of the steep and flat veins. The gross structure of the vein system consists of two steeply dipping veinsthe main lode and the northern vein-and an intervening set of flatter veins. It is not known whether the flat veins cut or join the steep veins, but data from other parts of the district suggest the latter. The stronger of the two flat veins strikes more easterly than the steep veins and accordingly the intersection of this flat vein with the northern steep vein should plunge about (calculated) $10^{\circ} \mathrm{NE}$. This intersection, if the observed strikes and dips of these two veins remains about the same, should be about 60 feet southwest of the southwestern face of the drift on the northern steep vein.

\footnotetext{
${ }^{25}$ Analyses by the U.S. Geological Survey. Analysts: S. P. Furman, Tames Wahlberg, Mary Finch.
}

\section{FREELAND-LAMARTINE DISTRICT}

By J. E. HARRISON and J. D. WELLs

Several widely scattered radioactive anomalies have been found in the Freeland-Lamartine district, but so far as known all are small, and probably not economically important. A brief description of the occurrences at each locality is given below ; for a more comprehensive description of the workings and geology of each mine the reader is referred to the report by Harrison and Wells (1956).

\section{ARIADNE MINE}

About 75 percent of the dump shows abnormal radioactivity. A sample of fractured granite containing visible torbernite and dumontite (?) along the fractures assayed 0.039 percent equivalent uranium and 0.035 percent uranium.

\section{BELLE CREOLE TUNNEL}

Two small areas, each about 1 foot square, of abnormal radioactivity were sampled in the mine. A sample taken near the winze on the split vein assayed 0.010 percent equivalent uranium and 0.002 percent uranium; a sample from the crosscut off of the main tunnel assayed 0.037 percent equivalent uranium and 0.033 percent uranium. About 10 percent of the dump at the shaft southwest of the tunnel portal is abnormally radioactive. A grab sample of limonitic vein material from this dump assayed 0.006 percent equivalent uranium and 0.002 percent uranium.

\section{BRAZIL MINE}

Radioactive material was found on the dumps of the lower adit and shaft. A grab sample from the lower adit dump assayed 0.040 percent equivalent uranium and 0.038 percent uranium, and a grab sample from the shaft dump assayed 0.013 percent equivalent uranium and 0.008 percent uranium. The samples consisted of limonitic vein material.

\section{CRAZY GIRL MINE}

One sample of radioactive vein material was collected from the hanging-wall side of the vein on the second level of the mine. The material assayed 0.033 percent equivalent uranium and 0.026 percent uranium.

\section{DIAMOND MOUNTAIN MINE}

A sample of mill concentrate of ore from the lower stope on the ore shoot near the breast of the workings assayed 0.078 percent equivalent uranium and 0.041 percent uranium. A grab sample of the gouge material on the eastward-trending vein near the breast of the workings in the lower tunnel assayed 0.16 percent 
equivalent uranium and 0.046 percent uranium; a grab sample of gouge from the split on the subleviel assayed 0.30 percent equivalent uranium and 0.35 percent uranium. The uranium mineral or minerals could not_be separated from the gouge for identification.

\section{HARRISBURG MINE}

One small area of weathered vein material on the Harrisburg dumps is abnormally radioactive. A grab sample of the radioactive material assayed 0.015 percent equivalent uranium and 0.013 percent uranium.

\section{LAMARTINE MINE}

Abnormal radioactivity was noted on the Lamartine tunnel level and on the Old Stag tunnel level. In the Lamartine tunnel, intermittent abnormal radioactivity was noted in the area 600 feet to 1,660 feet from the portal. Three samples for assay were collected in this area. A sample of pyritic vein material assayed 0.007 percent equivalent uranium and 0.002 percent uranium. A sample of limonitic material about a quarter of an inch thick that was being deposited on the walls of the tunnel by water dripping from an old stope driven for gold contained 0.083 percent equivalent uranium and 0.15 percent uranium. A sample of gouge from the footwall of a cross vein, which was collected in an old drift about 25 feet above the Lamartine tunnel, gave 0.12 percent equivalent uranium and 0.11 percent uranium.

In the Old Stag tunnel abnormal radioactivity resulting from radon was noted near the portal and gradually increased in intensity toward the breast of the workings. No specific area of abnormal radioactivity could be isolated. A grab sample of limonitic material from the tunnel walls assayed 0.007 percent equivalent, uranium and 0.002 percent uranium.

\section{LITTLE JOHNIE GROUP}

One small 2-foot-square area of abnormal radioactivity was noted. in the lower tunnel. The area is in one of the gouge leads about 360 feet from the portal. A grab sample of the gouge assayed 0.017 percent equivalent uranium and 0.013 percent uranium.

In the middle tunnel, two local areas of abnormal radioactivity were noted. Both of these areas are near the west end of the main drift. A grab sample from a thin gouge lead assayed 0.037 percent equivalent uranium and 0.033 percent uranium. A grab sample from one of the eastward-trending veins assayed 0.002 percent uranium. No abnormal radioactivity was noted in the upper tunnel.

\section{LONE TREE MINE}

Slightly anomalous radioactivity was noted on the dumps at the Lone Tree and Lone Tree Extension shafts. The anomaly was noted over most of these dumps and was partly the result of fragments of bostonite porphyry. Radioactive material other than that in the dike rock could not be isolated well enough to sample.

Some of the vein material on the dump at the Lone Tree tunnel portal also is abnormally radioactive. A grab sample of limonitic vein material assayed 0.006 percent equivalent and 0.005 percent uranium.

\section{MILLER MINE}

Three small areas (each about 2 feet square) of abnormal radioactivity in composite vein material were noted in the mine. Grab samples assayed 0.006, 0.009, and 0.014 percent equivalent uranium and $0.003,0.004$, and 0.001 percent uranium respectively. A few scattered flakes of torbernite were observed in the samples.

\section{POOR MAN MINE}

A grab sample of limonitic vein material taken from the dump assayed 0.028 percent equivalent uranium and 0.023 percent uranium.

\section{CHICAGO CREEK AREA}

BY J. E. HARRISON and J. D. WELLS

Several abnormally radioactive localities are known in the Chicago Creek area, and the occurrences of geologic interest are described briefly below. As the deposit at the Martha $\mathrm{E}$ mine is of particular interest, it is described in detail. For additional information on the mine workings and geology of the region the reader is referred to the report by Harrison and Wells (1958).

\section{ALPINE MINE}

One sample of radioactive limonitic vein material assaying 0.008 percent equivalent uranium and 0.002 percent uranium was taken from the Alpine dump. About 1 percent ( 28 square feet) of the surface area of the dump is radioactive.

\section{BLACKWOOD MINE}

The dump of the small shaft contained about 3 square feet of radioactive limonitic vein material. A sample taken from this area assayed 0.011 percent equivalent uranium and 0.005 percent uranium.

\section{BRUCE MINE}

Abnormal radioactivity was found on the main Bruce shaft dump and on the dump of a small prospect shaft 
about 2,000 feet to the east. On the main dump the anomaly was somewhat less than twice the background count on an area of about 10 square feet. A sample of limonitic vein material from the dump of the prospect shaft contained 0.009 percent equivalent uranium and 0.007 percent uranium. One-third of the dump, 65 square feet, showed anomalous radioactivity.

\section{BRUNSWICK TUNNEX}

About one-fourth of the Brunswick tunnel dump is abnormally radioactive. A sample of limonitic vein material collected from the dump assayed 0.006 percent equivalent uranium and 0.002 percent uranium. No abnormal radioactivity was found underground, but only a very small part of the mine was accessible.

\section{Chicago mine}

One area of abnormally radioactive material was found about 120 feet from the portal of the mine, at the junction between a friction breccia and a gougy pyritic and copper-stained vein. A 9-inch chip sample from the footwall of the friction breccia assayed 0.032 percent equivalent uranium and 0.033 percent uranium. No discrete uranium minerals could be identified.

\section{DIXIE MINE}

The radioactive material was found on about 200 square feet of the dump of the Dixie tunnel. A sample of the limonitic vein material assayed 0.012 percent equivalent uranium and 0.009 percent uranium. No abnormal radioactivity was found underground in the accessible parts of the vein.

\section{ECLIPSE MINE}

About one-fourth of the dump surface is abnormally radioactive. A sample of vein material taken from this area assayed 0.006 percent equivalent uranium and 0.003 percent uranium.

\section{GOMER MINE}

About half of the dump surface shows abnormal radioactivity. The radioactivity is associated with the vein material which consists principally of sphalerite and quartz with minor amounts of pyrite and galena. A grab sample of the radioactive vein material assayed 0.068 percent equivalent uranium and 0.072 percent uranium. No discrete uranium minerals could be identified.

\section{HUMBOLDT MINE}

Two areas containing abnormal radioactivity were found on the third level of the Humboldt mine. One of the areas begins 465 feet from the portal and extends about 30 feet southwest. The first 5 feet show the highest radioactivity. A grab sample of brecciated quartz, chalcedony, and pyrite assayed 0.045 percent equivalent uranium and 0.003 percent uranium. The other radioactive area begins about 566 from the portal and extends 4 feet to the southwest; both radioactive areas are about 8 feet high. A grab sample of brecciated and vuggy quartz, chalcedony, and pyrite containing scattered flakes of torbernite and thin coatings of sooty pitchblende assayed 0.10 percent equivalent uranium and 0.012 percent uranium.

\section{KATIE EMMETT MINE}

About 200 square feet of radioactive limonitic vein material was found on the dump of the lower tunnel. A sample of this material assayed 0.018 percent equivalent uranium and 0.004 percent uranium.

In a subsequent underground examination a radioactive part of the vein was found in the lower tunnel at an intersection of two weakly mineralized limonitic gouge veins 210 feet from the portal. No uranium minerals were identified.

\section{MARTHA E MINE}

The portal of the Martha $\mathrm{E}$ mine, at an altitude of 9,298 feet, is on the south side of Spring Gulch about 3,740 feet $N$. $63^{\circ}$ E. from the eastern peak of Alps Mountain.

The mine originally was a prospect on the Daisy Freese claim opened up by the Stanley Mines. In 1948, the claim was relocated by James Manning of Louisville, Colo., and he and Harvey Zook extended the prospect adit to 152 feet and put down a 15 -foot winze on the most promising part of the sheared zone disclosed by the drifting. Uranium-bearing minerals were noted in the sheared zone, and a detailed map of the surface and underground geology was made by the Geological Survey in 1951. A Defense Minerals Exploration Administration contract was let for extension of the winze to 100 feet and for a small amount of drifting on the 100 level. This work was completed in May 1953, but no minable material of ore grade was discovered. Since May 1953 the owners have extended the tunnel level for 70 feet, and during 1954 a shipment of 2,920 pounds of ore was hand-picked from high-grade spots in the winze. The settlement sheet for this ore gave an assay value of 0.14 percent uranium.

The mine consists of a 222 -foot adit trending about $\mathrm{N}$. $75^{\circ} \mathrm{W}$. and a winze that connects this level with about 75 feet of drifts and crosscuts on the 100 level (pl. 9). No stoping has been done in the mine.

The wallrock is predominantly migmatite that locally contains garnet or sillimanite. A granite pegmatite is exposed in the winze near the 100 level and crosscuts the foliation in the migmatite. A layer of granite gneiss and pegmatite is exposed in the northward-trending crosscut on the 100 level. The migmatite gradually 
becomes more granitic toward the breast of the southward-trending crosscut on the 100 level, and the vein zone may be confined to a migmatite layer between two layers of granite gneiss and pegmatite:

The adit has been driven into the southeast flank of a major open syncline, and the portal of the adit is about 400 feet southeast of the crest of this fold. The foliation in the rocks trends N. $80^{\circ}$ E. to N. $80^{\circ} \mathrm{W}$. in the area of the mine, and this trend has probably influenced the direction of shear in the rocks.

The vein zone in the Martha $\mathrm{E}$ mine is less well defined and contains many more minor slips and fractures than the typical lode zones seen in mines of the surrounding area. The sheared zone is wider than the grentest width exposed by the mine workings, but the fractures that are mineralized or that have alteration along them appear to be confined to a width of about 20 feet and to the less granitic parts of the migmatite.

The shear zone as a whole trends about $\mathrm{N} .75^{\circ} \mathrm{W}$., dips about $45^{\circ} \mathrm{N}$., and is subparallel to the foliation. The most persistent single shear in the mine ( $a$ on pl. 9 ) was carried in the back of the winze and is exposed on the adit level and 100 level. This shear splits or bends near the winze; the eastern part trends about N. $80^{\circ} \mathrm{W}$. but the western part on both levels trends about N, $68^{\circ}$ W. The development in the mine is insufficient to allow anything but speculation as to whether the splitting or bending has exerted an influence on the location of the ores.

The shears contain gouge, altered wallrock, and locally pyrite, chalcopyrite, galena, and sphalerite in a quarty gangue. Pyrite is commonly the only sulfide visible, and where the other sulfides are present, they are in trace amounts. Some black chalcedonic quartz is present at places in the mine. The sulfides are in 1-inch thick stringers that are sheared or in fragments scattered through the gouge and altered wallrock of the shenrs.

Of particular interest are the occurrence and distribution of the secondary minerals limonite, autunite, torbernite, and sooty pitchblende. The presence of limonite throughout the mine workings indicates that the workings are all within the zone of oxidation.

The uranium minerals occur in pods or bunches along the shear's and seem to alternate with areas containing only gouge and altered wallrock. The winze section (pl. 9) suggests that these alternations occur about every 10 feet. In greater detail, the sooty pitchblende occurs within or along an individual shear and autunite and torbernite occur in the footwall of the shear, as flakes or pods along the foliation of the wallrock, or along joint surfaces. This tendency suggests that the torbernite and autunite were deposited by ground water percolat- ing through the shear zone. The sooty pitchblende probably was the source for the uranium in the colored secondary minerals. The sooty pitchblende occurs as thin coatings on fractures confined to, but at places crosscutting a shear. Probably the sooty pitchblende was derived from hard primary pitchblende by oxidation.

Channel samples were cut across the radioactive shears in the winze; the west wall was sampled at 4foot intervals and the east wall at 8-foot intervals (pl. 9 ). The average grade of 22 samples from the west wall is 0.031 percent uranium, and that of 12 samples from the east wall is 0.022 percent uranium. The average width of the samples from both walls of the winze is 1.25 feet.

Samples of similar average grade and width were collected along the tunnel level and the 100 level although no attempt was made to sample systematically.

\section{MUSCOVITE TUNNEL}

About half of the surface of the upper dump shows abnormal radioactivity. This radioactivity is apparently confined to fractured fragments of biotite-muscovite granite that contains torbernite along fractures and disseminated through the rock with biotite. A grab sample of this radioactive material assayed 0.047 percent equivalent uranium and 0.046 percent uranium.

\section{ORINOCO TUNNEL}

The abnormal radioactivity of the Orinoco dump is limited to a 10 -foot-square area near the portal. The radioactivity is in pegmatite and is not associated with vein material. A grab sample from the dump assayed 0.18 percent equivalent uranium and 0.22 percent uranium. After the results of the assay were known the surface above the tunnel was examined for radioactivity. as the tumnel was inaccessible because of bad air. During this examination a radioactive pegmatite dike was found in an outcrop about 200 feet up the slope from the portal. The pegmatite is probably associated with the biotite-muscovite granite.

\section{SILVER LINK TUNNEL}

The abnormal radioactivity is limited to a small area of limonitic vein material on the dump. A grab sample taken from this area assayed 0.007 percent equivalent uranium and 0.002 percent uranium.

\section{TYONE MINE}

A small amount of radioactive material is on the lower tunnel level about 680 feet from the portal. A fracture at the end of a short crosscut tunnel contains a film of black radioactive material tentatively identified as sooty pitchblende. On the wall a few feet beyond the 
crosscut tunnel is a small area of radioactive, recently formed, limonitic precipitate.

\section{WALLACE TUNNEL}

A few abnormally radioactive limonitic vein fragments were found on the dump of the Wallace tunnel. A sample of the material assayed 0.014 percent equivalent uranium and 0.006 percent uranium. No abnormally radioactive areas were found underground along the accessible parts of the veins.

\section{LITERATURE CITED}

Adams, J. W., and Stugard, Frederick, Jr., 1956, Wall-rock control of certain pitchblende deposits in Golden Gate Canyon, Jefferson County, Colorado: U.S. Geol. Survey Bull. 1030-G, p. 187-209.

Alsdorf, P. R., 1916, Occurrence, geology, and economic value of the pitchblende deposits of Gilpin County, Colorado: Econ. Geology, v. 11, p. 266-275.

Armstrong, F. C., 1952, Pitchblende deposits on Quartz Hill, Central City district, Gilpin County, Colorado [abs.] : Geol. Soc. America Bull., v. 63, no. 12, pt. 2, p. 1232.

Ball, S. H., 1906, Pre-Cambrian rocks of the Georgetown quadrangle, Colorado: Am. Jour. Sci., 4th ser., v. 21, p. 371-389.

Bastin, E. S., 1915, Geology of the pitchblende ores of Colorado: U.S. Geol. Survey Prof. Paper 90-A, p. 1-5.

1916, Discussion. Occurrence, geology, and economic value of the pitchblende deposits of Gilpin County, Colorado: Econ. Geology, v. 11, p. 681-685.

1950, Interpretation of ore textures: Geol. Soc. America Mem. 45, $101 \mathrm{p}$.

Bastin, E. S., and Hill, J. M., 1917, Economic geology of Gilpin County and adjacent parts of Clear Creek and Boulder Counties, Colorado: U.S. Geol. Survey Prof. Paper 94, $379 \mathrm{p}$.

Brooker, E. J., and Nuffield, E. W., 1952, Pitchblende from Lake Athabaska, Canada, pt. 4 of Studies of radioactive compounds : Am. Mineralogist, v. 37, p. 363-385.

Clarke, F. W., 1903, Mineral analyses from the laboratories of the United States Geological Survey, 1880 to 1903: U.S Geol. Survey Bull. 220, 119 p.

- 1924, The data of geochemistry 5th ed. : U.S. Geol. Survey Bull. 770, $841 \mathrm{p}$.

Cloos, Ernst, 1946, Lineation, a critical review and annotated bibliography: Geol. Soc. America Mem. 18, 122 p.

Collins, G.E., 1903, The relative distribution of gold and silver values in the ores of Gilpin County, Colorado: Inst. Mining Metallurgy Trans., v. 12, p. 480-495.

Croft, W. J., 1954, An X-ray line study of uraninite: U.S. Atomic Energy Comm. RME-3096 (pt. 2), issued by Tech. Inf. Service, Oak Ridge, Tenn., p. 7-71.

Drake, A. A., Jr., 1957, Geology of the Wood and East Calhoun mines, Central City district, Gilpin County, Colorado: U.S Geol. Survey Bull. 1032-C, p. 129-170.

Emmons, W. H., 1917, The enrichment of ore deposits : U.S. Geol. Survey Bull. 625, $530 \mathrm{p}$.

Faul, Henry, ed., 1954, Nuclear geology-a symposium on nuclear phenomena in the earth sciences: New York, John Wiley \& Sons, $414 \mathrm{p}$.

Gruner, J. W., 1952, New data on syntheses of uranium minerals: U.S. Atomic Energy Comm. RMO-983, issued by Tech. Inf. Service, Oak Ridge, Tenn.
Harrison, J. E., 1955, Relation between fracture pattern and hypogene zoning in the Freeland-Lamartine district, Colorado: Econ. Geology, v. 50, p. 311-320.

Harrison, J. E., and Leonard, B. F., 1952, Preliminary report on the Jo Reynolds area, Lawson-Dumont district, Clear Creek County, Colorado: U.S. Geol. Survey Circ. 213, 9 p. [1953].

Harrison, J. E., and Moench, R. H., 1961, Joints in Precambrian rocks, Central City-Idaho Springs area, Colorado: U.S. Geol. Survey Prof. Paper 374-B, p. B1-B14.

Harrison, J. E., and Wells, J. D., 1956, Geology and ore deposits of the Freeland-Lamartine district, Clear Creek County, Colorado: U.S. Geol. Survey Bull. 1032-B, p. 33-127.

1959, Geology and ore deposits of the Chicago Creek area, Clear Creek County, Colorado: U.S. Geol. Survey Prof. Paper 319, $92 \mathrm{p}$.

Hawley, C. C., and Moore, F. B., 1955, Control of uranium deposition by garnet-quartz rock in the Fall River area, Clear Creek County, Colorado [abs.] : Geol. Soc. America Bull., v. 66, no. 12, pt. 2, p. 1675 .

Hill, M. L., 1947, Classification of faults : Am. Assoc. Petroleum Geologists Bull., v. 31, p. 1669-1673.

Hillebrand, W. F., 1891, On the occurrence of nitrogen in uraninite and on the composition of uraninite in general : U.S. Geol. Survey Bull. 78, p. 43-79.

Holmes, Arthur, 1947, The construction of the geological time scale: Geol. Soc. Glasgow Trans., v. 21, pt. 1, p. 117-152.

Johnson, D. H., 1954, Radiometric prospecting and assaying, in Faul, Henry, (ed.), Nuclear geology: New York, John Wiley \& Sons, p. 219-241.

Kidd, D. F,, and Haycock, M. H., 1935, Mineragraphy of the ores of Great Bear Lake: Geol. Soc. America Bull., v. 46, p. 879-960.

King, R. U., Leonard, B. F., Moore, F. B., and Pierson, C. T., 1953, Uranium in the metal-mining districts of Colorado: U.S. Geol. Survey Circ. 215, 10 p.

Larsen, E. S., Jr., and Phair, George, 1954, The distribution of uranium and thorium in igneous rocks, in Faul, Henry, ed., Nuclear geology: New York, John Wiley \& Sons, p. 75-88.

Larsen, E. S., Jr., Phair, George, Gottfried, David, and Smith. W. L., 1956, Uranium in magmatic differentiation, in Contributions to the geology of uranium and thorium by the United States Geological Survey and Atomic Energy Commission for the United Nations International conference on peaceful uses of atomic energy, Geneva, Switzerland, 1955: U.S. Geol. Survey Prof. Paper 300, p. 65-74

Leonard, B. F., 1952, Relation of pitchblende deposits to hypogene zoning in the Front Range mineral belt, Colorado [abs.]: Geol. Soc. America Bull., v. 63, no. 12, pt. 2, p. $1274-1275$.

Lindgren, Waldemar, 1933, Mineral deposits : 4th ed., New York, McGraw-Hill Book Co., 930 p.

Lovering, T. S., 1942, The mineral belt of the Oolorado Front Range in Newhouse, W. H., ed., Ore deposits as related to structural features: Princeton, Princeton Univ. Press, $p$. 79-93.

Lovering, T. S., and Goddard, E. N., 1938, Laramide igneous sequence and differentiation in the Front Range, Colorado: Geol. Soc. America Bull., v. 49, p. 35-68.

1950, Geology and ore deposits of the Front Range, Colorado: U.S. Geol. Survey Prof. Paper 223, 319 p. [1951].

Lovering, T. S., and Tweto, Ogden, 1953, Geology and ore deposits of the Boulder County tungsten district, Colorado: U.S. Geol. Survey Prof. Paper 245, 199 p. [1954] 
McKelvey, V. E., Everhart, D. I., and Garrels, R. M., 1955, Origin of uranium deposits: Econ. Geology, 50th anniv. volume, p. $464-533$.

McKinstry, H. H., 1948, Mining geology: New York, PrenticeHall, $680 \mathrm{p}$.

Moench, R. H., Harrison, J. E., and Sims, P K., 1954, Precambrian structures in the vicinity of Idaho Springs, Front Range, Colorado [abs.]: Geol. Soc. America Bull., v. 65, 1. $1.383-1.384$.

- 1.962, Frecambrian folding in the Idaho Springs-Central City area, Front Range, Colorado [abs.]: Geol. Soc. America Bull., v. 73, p. 35-58.

Moore, F. B., and Butler, C. R., 1952, Pitchblende deposits at the Wood and Calhoun mines, Central City mining district, Gilpin County, Colorado: U.S. Geol. Survey Circ. 186, 8 p.

Moore, R. B., and Kithil, K. L., 1913, A preliminary report on uranium, radium, and vanadium: U.S. Bur. Mines Bull. 70, Min. Tech. 2, $101 \mathrm{p}$.

Newhouse, W. H., 1942, Structural features associated with the ore deposits described in this volume, in Newhouse, W. H. ed., Ore deposits as related to structural features: Princeton, Princeton Univ. Press, p. 9-54.

Palache, Charles, Berman, Harry, and Frondel, Clifford, 1944, Dana's system of mineralog., v. 1. New York, John Wiley \& Sons, $834 \mathrm{p}$.

_ 1.951., Dana's system of mineralogy, v. 2 : New York, John Wiley \& Sons, 1124 p.

Penrce, Richard, 1.898, Some notes on the occurrence of uraninite in Colorado: Colorado Sci. Soc. Proc., v. 5, p. 156-158.

Phair, George, 1.952, Radioactive Tertiary porphyries in the Central City distriot, Colorado, and their bearing upon pitchblende deposition: U.S. Geol. Survey Trace Elements Inv. Rept. 247, issued by U.S. Atomic Energy Comm., Tech. Inf. Service, Oak Ridge, Tenn.

Phair, George, and Levine, Harry, 1953, Notes on the differential leaching of urmium, radium, and lead from pitchblende in H.SO, solutions: Hcon. Geology, v. 48, p. 358-369.

Ricknrd, Forbes. 1913, Pitchblende from Quartz Hill, Gilpin County, Colorado: San Francisco, Calif., Mining \& Scientific I'ress, v. 106, no. 23, p. $851-856$.

Sheridan, D. M., Maxwell, C. H., Albee, A. L., and Van Horn, Richard, 1958, Preliminary map of bedrock geology of the Ralsston Buttes quadrangle, Jefferson County, Colorado: U.S. Geol. Survey Mineral Inv. Field Studies Map MF-179.

Sims, F. K., 1956a, Paragenesis and structure of pitchblendebenring veins, Central City district, Colorado: Econ. Geology, v. 5.1, p. 739-756.

- 19560 , Uranium deposits in the Front Range, Colorado: Mines Mag., v. 46, no. 3, p. 77-79.
Sims, P. K., and Barton, P. B., Jr., 1961, Some aspects of the geochemistry of sphalerite, Central City district, Colorado: Econ. Geology, v. 56, p. 1211-1237.

- 1962, Hypogene zoning and ore genesis, Central City district, Colorado, in Engel, A. E. J., and others, Petrologic studies (Buddington volume) : Geol. Soc. America, p. 373396.

Sims, P. K., Drake, A. A., Jr., and Tooker, E. W., 1963, Economic geology of the Central City district, Gilpin County, Colorado: U.S. Geol. Survey, Prof. Paper 359, 231 p.

Sims, P. K., Osterwald, F. W., and Tooker, E. W., 1955, Uranium deposits in the Eureka Gulch area, Central City district, Gilpin County, Colorado: U.S. Geol. Survey Bull. 1032-A, p. $1-3.1$.

Sims, P. K., Phair, George, and Moench, R. H., 1958, Geology of the Copper King mine, Larimer County, Colorado: U.S. Geol. Survey Bull. 1032-D, p. 171-221.

Sims, P. K., and Tooker, E. W., 1955, Localization of metatorbernite in altered wall rocks, Central City district, Gilpin County, Colorado [abs.]: Geol. Soc. America Bull., v. 66 . no. 12 , pt. 2 , p. 1680 .

1956. Pitchblende deposits in the Central City district. and adjoining areas, Gilpin and Clear Creek Counties, Colorado: United Nations International Conf. Peaceful uses of Atomic Energy Proc., v. 6, Geology of uranium and thorium, p. 265-269; published also in U.S. Geol. Survey Prof. Paper 300 , p. 105-111.

Spurr, J. E., Garrey, G. H., and Ball, S. H., 1908, Economic geology of the Georgetown quadrangle, Colorado: U.S. Geol. Survey Prof. Paper 63, 422 p.

Tooker, E. W., 1956, Altered wall rocks along vein deposits in the Central City-Idaho Springs region, Colorado, in Swineford, Ada, ed., Clays and clay minerals, Natl. Acad. Sci., Natl. Research Council Pub. 456, p. 348-361.

Vitanage, P. W., 1954, Sandstone dikes in the South Platte area, Colorado: Jour. Geolog, , v. 62, p. 493-500.

Waring, C. L., and Annell, C. S., 1953, Semiquantitative spectrographic method for analysis of minerals, rocks, and ores: Anal. Chem. v. 25, p. 1174-1179.

Wells, J. D., 1960, Petrography of radioactive Tertiary rocks, central part of Front Range mineral belt, Gilpin and Clear Creek Counties, Colorado: U.S. Geol. Survey Bull. 1032-E, p. 223-272 [1961].

Wells, J. D., and Harrison, J. E., 1954, Radioactivity reconnaissance of part of north-central Clear Creek County, Colorado : U.S. Geol. Survey Circ. 345,9 p.

Young, E. J., and Sims, P. K., 1961, Petrography and origin of xenotime and monazite concentrations, Central City district, Colorado: U.S. Geol. Survey Bull. 1032-F, p. 273299. 



\section{N D E X}

[Major references are in italic]

A

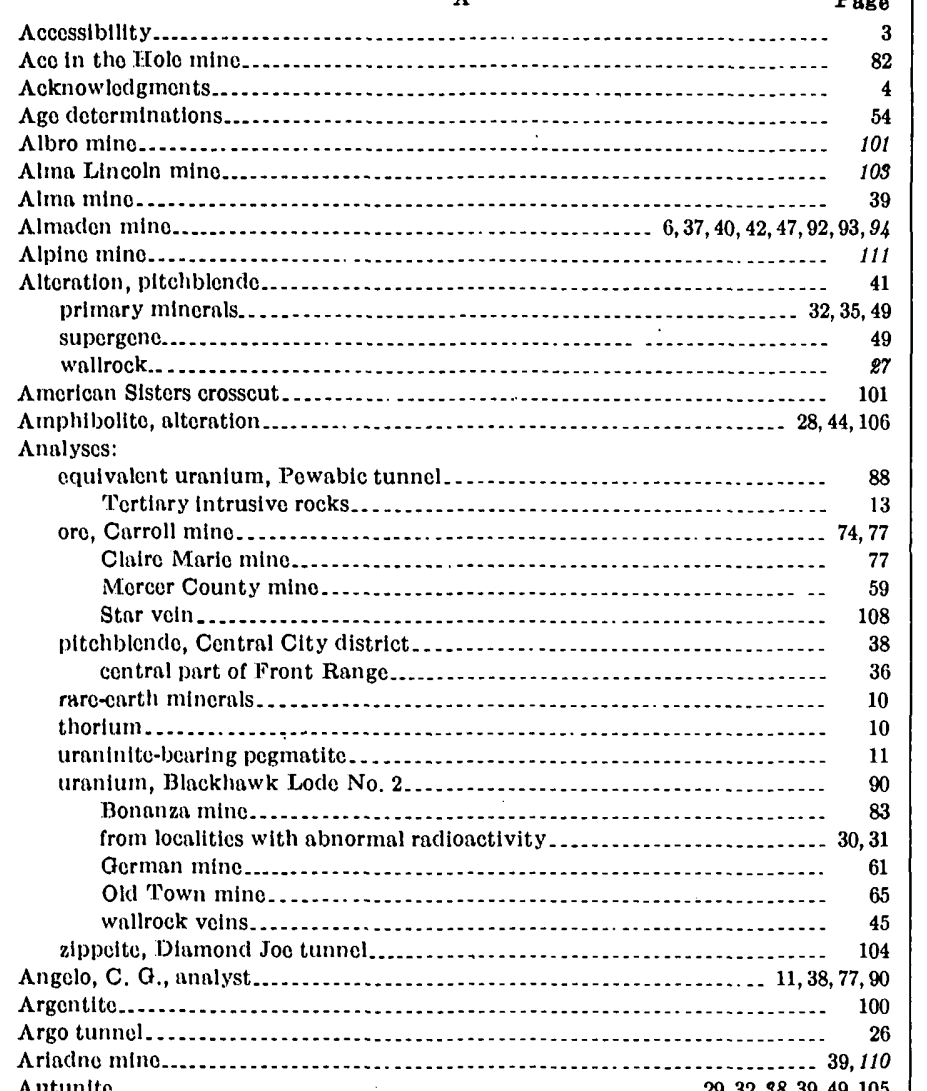

Autunlte............................................... 29, 32, 38, 39, 49, 105

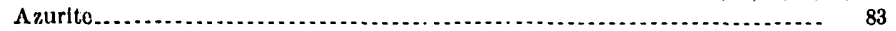

\section{B}

Barite...

$22,24,85,94$

Bayloyite............ 39,106

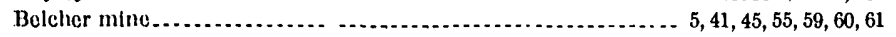

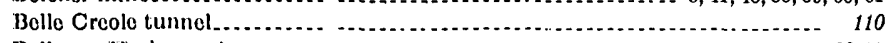

Bellevuc-1ludson mine....... ........................................ 98,99

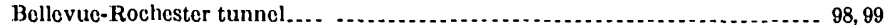

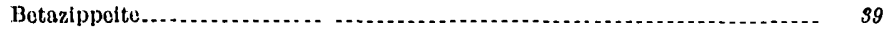

Bibliography

Biotite.

$11,27,28$

Bivens, H. E., anßlyst........................................................ 74, 77, 90

Black Eaglo mill.

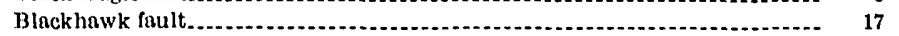

Blackhawk Lode No. $2 \ldots \ldots \ldots . . . . . .38,51,88,89,90,91,92$

Blackwood mine

Bonanza mine. $47,82,84$

Bostonite porphyry $. . . . . . . . . . . . . . . . . . . . . . . . .44,53,55,56,62,67,68,82,104$

Boyes, G. W., analyst.

Brazil mine.

Breccia reefs

Bruce mine.

Brunswick tunnel

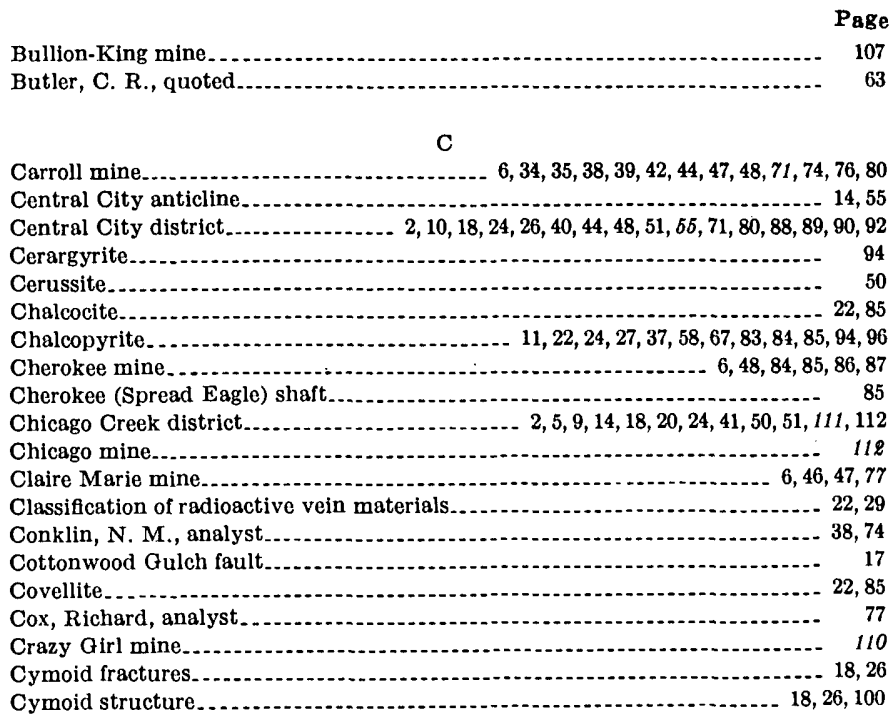

D

Daily tunnel.

Daywitt, R., analyst

Diamond Joe mine

Diamond Joe tunnel.

Daisy Freese claim

Discovery shaft.......................................................................... 63, 64

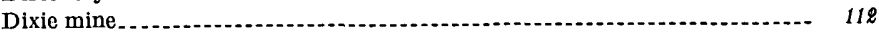

Dory Hill fault........................

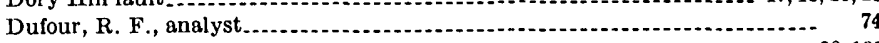

Dumontite . .

East Calhoun mine................................... 6, $34,40,41,43,48,62,69$ East Flack claim

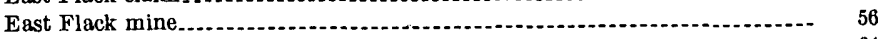

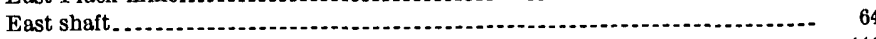

Eclipse mine. . .

Electrum

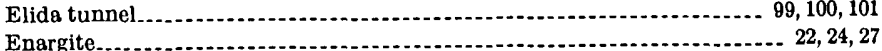

Enargite

Eureka Gulch district. .

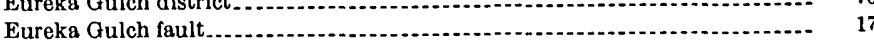

Fairfield mine

Fairmont shaft .

Fall River area

Faults, classification....................................................... $15,16,17,18$

origin

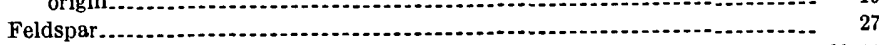

Finch, Mary, analyst

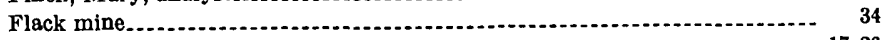

Floyd Hill fault. . .

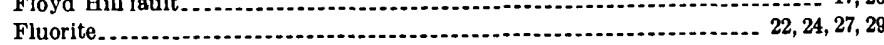


Page

Freeland-Lamartine district Furman, S. P.. analyst. $2,18,24,25,26,110$ $11,59,65,74,77,88$

Galena... $11,22,23,24,25,27,29,37,50,58,59,67,83,85,94,96,100$ Garnetiferous lime silicate gneiss Geography...

German mine

Golconda mine

Golconda tunnel

Gold.

Gold Lode..

Gold Quartz mine.

Golden Calf mine

Gomer mine.

Goss, W. D., analyst

Greenside mine

\section{H}

Hamilton, J. C., analyst

Harrisburg mi

Havens, R. G., analyst......................... $10,38,74$

Hematite.

Herrick shaft.

Hidden Treasure mine

Highlander claim

History, geologic geomorphic mining.

Hot Time lateral

Hudson tunnel.

Humboldt mine.

Hypogene minerals

Ida Mae mine

Idaho Springs district

Idaho Springs fault

Illinois Gulch fault

Illite

Iron mine.

Iron shaft.

$44,93,94,96,97,98$

$5,41,45,46,54,55,59,60,61$ $6,37,47,50,92,93,96,98$ $22,24,27,67,85,94,96$

, 94,96

83

$J$

J. M. Emerson-Gem fault

Jasper Cuts.

Jennie Lind No, 1 tunnel Jo Reynolds mine $4,5,34,37,40,55,98,99,101$ Johannite.

Johnson, Carmen, analyst

Joints.

Justice Hill district.

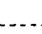

$47,55,82$
25,15 $\mathbf{K}$

Kaolinite Kasolite ................ 29, 32, $98,49,50,51,80,82,88,90$

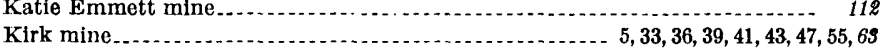
L Laramide faults . . . . . . . . . . . . . . . .

Lamartine mine

Lawson area.

Lawson-Dumont-Fall River district

Lipp, H. H., analyst

Lincoln mine.

Little Annie mine

Little Johnie mine.

Little Mattie mine

Location of area

Localization of ore

Lone Tree mine.

\section{M}

MAB tunnel

McCall, B., analyst

McClure, J., analyst

McKay shaft

Malachite.
Mallory, E. C., analyst............ Page

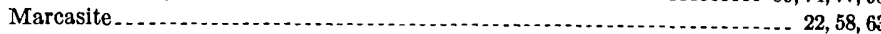

Marmatite.............................. 58, 59

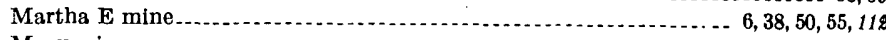

Mary mine $\ldots \ldots \ldots \ldots \ldots \ldots . \ldots \ldots, 47,92,93,94,96,98$

Mercer County claim.......................................

Mercer County mine $\ldots \ldots \ldots \ldots \ldots \ldots \ldots \ldots \ldots \ldots$

Meta-autunite ....................................... $\$ 8,90$

Metatorbernite $\ldots . . .29,32,38,49,50,51,80,82,88,90,91,105,106$

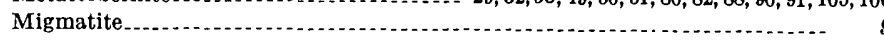

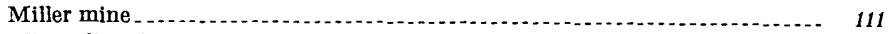

Mines, list of

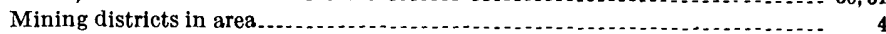

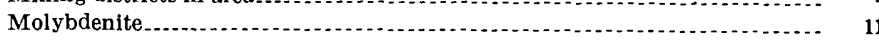

Monazite

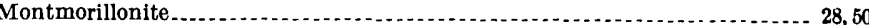

Moore, F. B., quoted

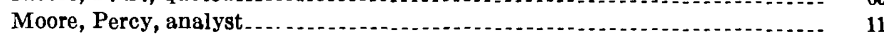

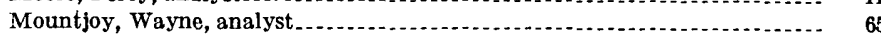

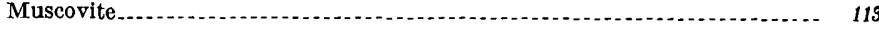

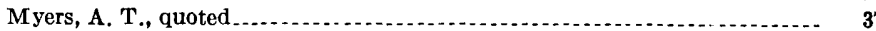

Mylonite

$\mathbf{N}$

New Bedford mine........................ 39, 10

New Bedford tunnel

New Bedford tunnel
Niccolite $\ldots \ldots$

Nigger Hill.................. 27, 42, 49, 50,51, 53, 55, 70, 71, 81

O

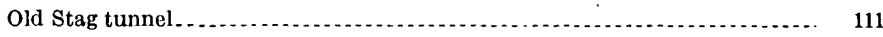

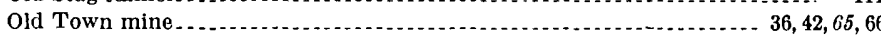

Ore, structure . . .

zonal arrangement.............. 24

Origin of uranium deposits ............................................. 52

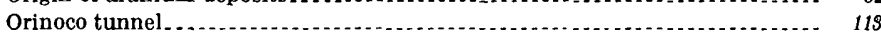

Outerbridge, W. F., analyst

Oxidation of pitchblende...............................................

Pararammelsbergite . ... . . .

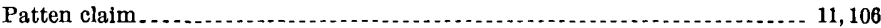

Patton, J. W., analyst........... 11,74

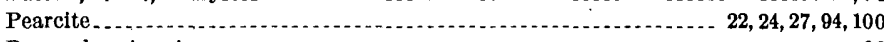

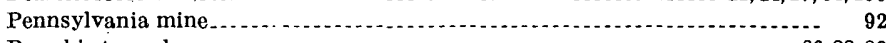

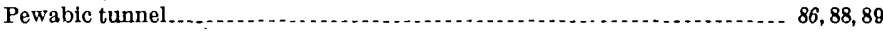

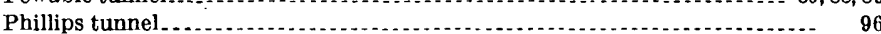

Photomicrographs,

Pitchblende, alteration

chemical analysis

discovery ........

distribution ...................................................................... 41

minor elements in . ................... 36

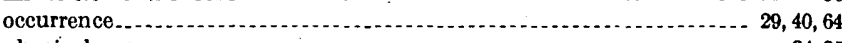

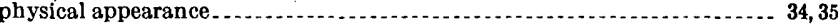

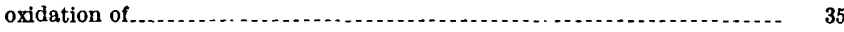

precipitation of

texture

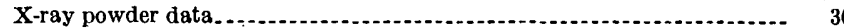

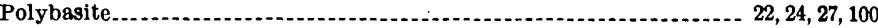

Poor Man mine.

Powhatan tunnel

Precambrian faults.

Precambrian rocks................................. 6, 7, 9, 12, 13, 16, 19, 78, 81, 82, 99

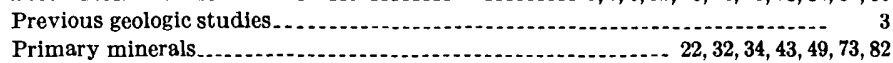

Primary minerals.
Production. See particular mines.

Proustite............................ 94, 96, 100

Pyrite

Quartz Hill.

Q

Radioactivity.

$\mathbf{R}$

Red Jacket mine

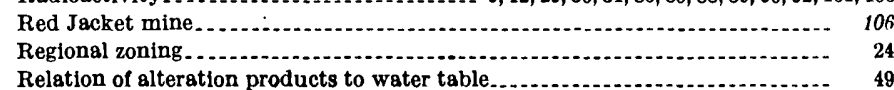


Relation of pitchblendo to vein minerals.

Relation of uranium deposits, to depth

to fault sets.

to sulfide minernis

Remington mine.

R.H.D. mine.

Rhodochrositc.

Robinenu prospect

Rosholt, John, annlyst

Ross shaft.

Russell Gulch district

Russcll Gulch fault

St. Anthony mino

Sawatch formation

Schafer, D. L., analyst

Schroeckingerite.

Schuch, J. P., analyst

Secondary mincrals.

Sericite.

Seven-Forty mine

Shafter mine

Siderite.

Sllent Friend shaft

Silver.

Silver Hill.

Silver Link tunnel

Skinner, D. L., anạlyst

Smith, R., analyst.

Specie Payment mine.

Sphalerite.

Springdale mino

Standard mine.

Stanloy mino

star mine...

Stockwell, D. L., analyst

Sunnyside mine.

Supergene minerals

Sweency, Ann, analyst.

$6,51,78,79,80$

\section{$\mathrm{S}$}

Telegraph mino.

Tennantite.

Tortiary rocks.

Tetrahedrite-tennantite

Thortum.

Thucholite..

Topeku dike

Torbornite.

Tourmaline

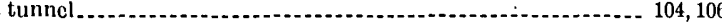

Two Sisters minc.......................................... 6, 38, 47, 50, 51, 77, 80, 81

Tyone mine

Types of veins. 113
$22,23,24,25$

$\mathrm{U}$

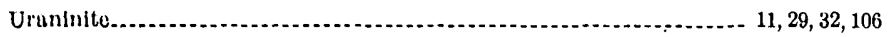

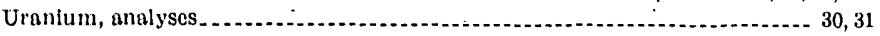

distribution.

future production.

source.

Urunophane.

tion..........

30,31
29

55

59,54

Veins:

$\mathrm{V}$

Albro

101,103

A mertcan Sisters

Bangor...

Becky Sharp

Bellovue.

Blackhawk.

Blazlng Star

Bonanza.

Boodle.
Veins-Continued

Calhoun..

Carroll............................................................ 42, 43,47,51,72,73

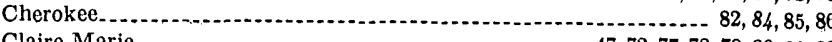

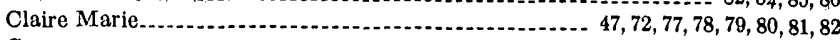

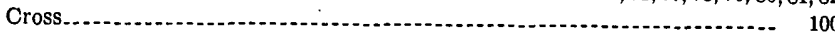

Denbigh_................................................................... 42, 67, 68

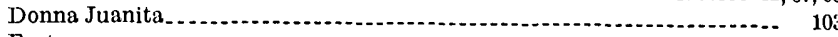

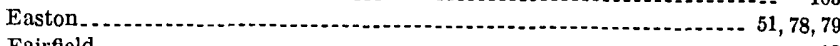

Fairfield

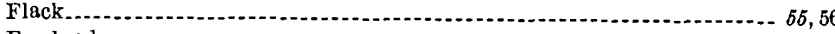

Freeland . . . .

Gardner

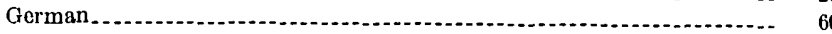

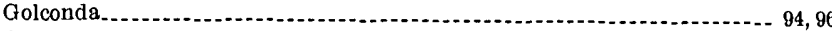

Gold Rock . . .

Golden Calf.

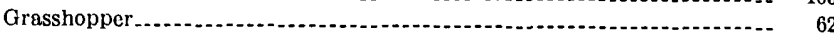

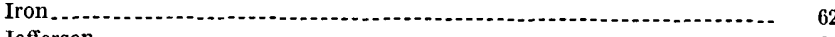

Jefferson

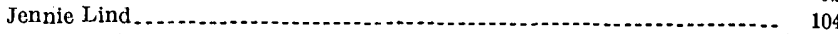

Jo Reynolds.

Josephine.................................................................... 103

Kirk............................................................................ 47, 63

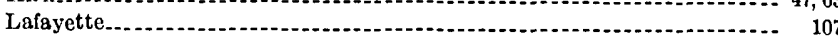

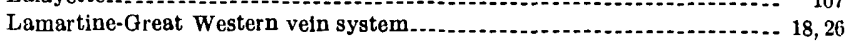

Last Chance-Burro.

Lincoln

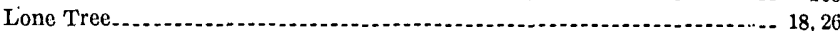

Mammoth

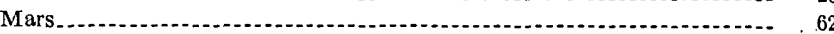

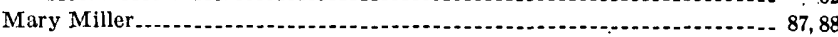

Mayflower............................... 107

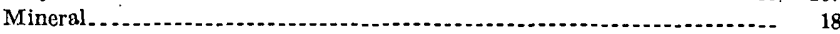

Old Town

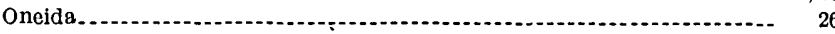

R.H.D......... 78, 79

Ravenswood................................................................. 78, 79

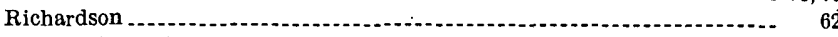

Rocky Mountain Terror

Shafter

Shamrock. ...

Silent Friend.

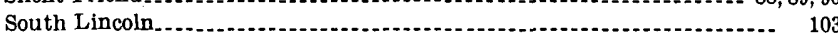

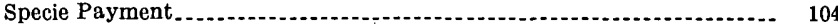

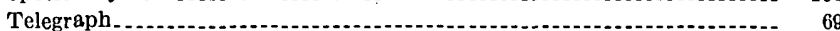

Two Sisters................

$37,39,40,41,43,48,69$

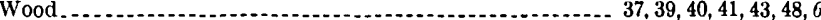

Virginia Canyon...................................................... 103, 104, 106

Wahlberg, James, analyst........... W

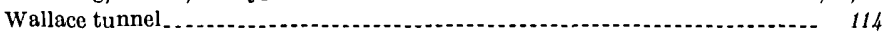

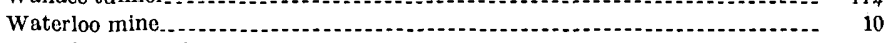

West Calhoun mine.

West Flack claim .............................................................. 55

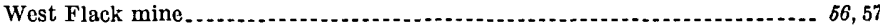

Widow Woman mine.

Wild Rose mine

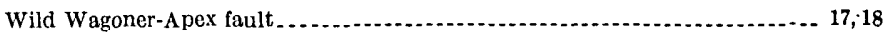

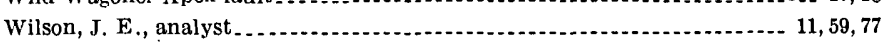

Wood dike group. ......................................................... 55

Wood mine $-\ldots, 5,33,36,41,43,55,68,69,70$

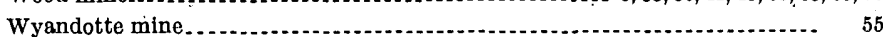

$\mathbf{x}$

Xenotime

$\mathbf{Y}$

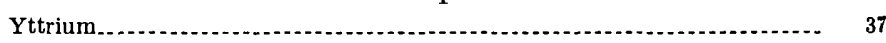

Zippeite
Zirconium 
The U:S. Geological Survey Library has cataloged this publication as follows:

Sims, Paul Kibler, 1918-

Geology of uranium and associated ore deposits, central part of the Front Range mineral belt, Colorado, by P. K. Sims and others. Washington, U.S. Govt. Print. Off., 1963.

viii, 118 p. illus., maps (part col.) diagrs., tables. $29 \mathrm{~cm}$. (U.S. Geological Survey. Professional paper 371)

Part of illustrative matter folded in pocket.

Prepared on behalf of the U.S. Atomic Energy Commission.

Bibliography : p. 114-115.

(Continued on next card)

Sims, Paul Kibler, 1918-

Geology of uranium and associated ore deposits, central part of the Front Range mineral belt, Colorado. 1963. (Card 2)

1. Geology-Colorado-Front Range. 2. Uraniutan ores-Colorado. 3. Ore-deposits-Colorado. 4. Mines and mineral resources-Colorado. I. Title: Front Range mineral belt, Colorado. ‘(Series) 